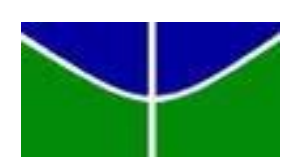

Universidade de Brasília - UnB

Faculdade de Planaltina - FUP

Programa de Pós-Graduação em Gestão Pública - PPGP

Mestrado Profissional em Gestão Pública

JEREMIAS PEREIRA DA SILVA ARRAES

CONCURSO PÚBLICO EXECUTADO PELO CESPE/CEBRASPE: Um estudo sobre a oferta de espaço físico público disponível no Distrito Federal

Brasília 
CONCURSO PÚBLICO EXECUTADO PELO CESPE/CEBRASPE:

Um estudo sobre a oferta de espaço físico público disponível

no Distrito Federal

\begin{abstract}
Dissertação de Mestrado apresentada ao Programa de Pós-Graduação em Gestão Pública da Universidade de Brasília - Faculdade de Planaltina como requisito parcial para obtenção do título de Mestre em Gestão Pública.

Linha de atuação: Monitoramento e avaliação da gestão pública.

Orientadora: Profa. Dra. Andréa de Oliveira Gonçalves.
\end{abstract}


A773c Arraes, Jeremias Pereira da Silva.

Concurso Público Executado pelo CESPE/CEBRASPE: um estudo sobre a oferta de espaço físico público disponível no Distrito Federal / Jeremias Pereira da Silva Arraes. - 2016. 198 f. : il. ; $30 \mathrm{~cm}$.

Dissertação (mestrado) - Universidade de Brasília, Faculdade de Planaltina, Programa de Pós-Graduação em Gestão Pública, 2016.

Inclui bibliografia.

Orientação: Andréa de Oliveira Gonçalves.

1. CESPE/CEBRASPE. 2. Espaço Público. 3. Distrito Federal. 4. Concurso Público. I. Gonçalves, Andréa de Oliveira, 2016. II. Título.

CDU 35.082.1 
Universidade de Brasília - UnB

Faculdade de Planaltina - FUP

Programa de Pós-Graduação em Gestão Pública - PPGP

Mestrado Profissional em Gestão Pública

\section{CONCURSO PÚBLICO EXECUTADO PELO CESPE/CEBRASPE: \\ Um estudo sobre a oferta de espaço físico público disponível no Distrito Federal}

Dissertação de Mestrado apresentada ao Programa de Pós-Graduação em Gestão Pública da Universidade de Brasília - Faculdade de Planaltina como requisito parcial para obtenção do título de Mestre em Gestão Pública. Linha de atuação: Monitoramento e avaliação da gestão pública.

Orientadora: Profa. Dra. Andréa de Oliveira Gonçalves

Banca Examinadora

Profa. Dra. Andréa de Oliveira Gonçalves - Orientadora

PPGP/FUP/UnB

Prof. Dr. André Nunes - Membro

PPGP/FUP/UnB

Prof. Dr. Bruno Vinicius Ramos Fernandes - Membro

CCA/FACE/UnB

Prof. Dr. Jonilto Costa Sousa - Suplente

PPGP/FUP/UnB

Brasília, 27 de Abril de 2016. 
À minha querida esposa, Beatriz, que sempre me estimulou a dar este grande passo. Com muito amor, sabedoria e dedicação, esteve sempre ao meu lado, encorajando-me nas horas difíceis e aplaudindo-me nos momentos de glória. Obrigado, menina, por ser fonte de inspiração, apoio e ensino diário. 


\section{AGRADECIMENTOS}

A Deus, por me mostrar os caminhos nas horas incertas, me amparar nos momentos de dificuldade e angústia, fortalecer-me na superação das adversidades da vida e em minhas limitações, e guiar-me na realização de todos os meus sonhos.

À minha amada esposa Beatriz, por entender minha ausência, aguentar meus momentos de ansiedade e stress no período em que me dediquei ao Mestrado e por sempre estar ao meu lado incentivando a realização dos meus sonhos. Esta vitória também é dela!

À minha professora orientadora Andréa de Oliveira Gonçalves, por todo o conhecimento compartilhado, pelo exemplo profissional que muito admiro e a toda dedicação despendida durante a elaboração das linhas que se seguem.

À Universidade de Brasília (UnB), pela oportunidade e pela qualidade do ensino. Aos profissionais envolvidos no Programa de Pós Graduação em Gestão Pública (PPGP), bem como à Universidade de Lisboa, que por meio de seus representantes agregaram ainda mais conhecimento e valoração ao curso.

A todos os professores do PPGP, pelos ensinamentos; em especial, aos professores André Nunes e Alexandre Almeida, que conduziram todos os mestrandos na imersão à Portugal, dando o auxílio necessário para realizar as atividades, e aos professores Jonilton Sousa, Mario Ávila, Elioenai Dornelles e Luis Honorato, que tiveram participação decisiva na minha formação.

A toda minha família, que soube entender a minha ausência; em especial, à minha mãe Ana Julia, que sempre será o meu maior exemplo de competência e dedicação. 
Ao meu primo André e ao meu amigo Paulo Falcão, que desde que cheguei à Brasília, sempre me deram todo aporte familiar, acompanharam todas as minhas batalhas e me ajudaram a superar as dificuldades. Sem eles, certamente não teria chegado até aqui!

Finalmente, compartilho o sucesso do presente estudo com todos aqueles que estiveram comigo e me acompanharam na caminhada. 
"É melhor escrever errado a coisa certa, do que escrever certo a coisa errada".

Patativa do Assaré 


\section{RESUMO}

O presente estudo trata de uma análise sobre a locação de espaço físico para a realização de concursos públicos por meio de contratações realizadas pelo CESPE/CEBRASPE. Neste sentido, a pesquisa teve por objetivo verificar se no Distrito Federal tem-se a disponibilidade de espaço público similar ao espaço privado contratado com frequência pelo referido Centro de Seleção. A princípio, por meio de referencial teórico, discutiu-se sobre os principais temas ligados à despesa com locação de espaço público para a realização de seleções públicas, quais sejam: "conceito de público e privado", "locação de espaço público", "orçamento público", "concurso público" e "qualidade do gasto público". Também se fez uma descrição do cenário atual do quantitativo de instituições públicas no Distrito Federal e suas características, além da exposição do histórico das seleções realizadas no período 2009-2014 pelo CESPE/CEBRASPE, discutindo-se as características dos espaços contratados, a disponibilidade de espaço público no Distrito Federal e se este poderia substituir o espaço privado utilizado atualmente pelo CESPE/CEBRASPE para realização de concurso público. Trata-se de estudo de caso qualitativo, de natureza exploratório-descritivo. Os dados primários foram coletados por meio de entrevistas e os dados secundários foram coletados nas bases de dados do Censo Escolar 2014, SIAFI e documentos. Os resultados foram analisados por meio de análise documental, estatística descritiva e análise de conteúdo. Foi possível observar a evolução da arrecadação do CESPE/CEBRASPE e seu gasto com a locação de espaço físico no período 2009-2014. Concluiu-se que tem-se disponibilidade de espaço público similar ao espaço privado locado com freqüência pelo CESPE/CEBRASPE e que este poderia ser utilizado de forma prioritária nos eventos executados por este Centro de Seleção. Dessa forma, os gastos com locação de imóveis para a realização de concurso público serão otimizados.

Palavras-chave: Concurso público. Espaço público. Distrito Federal. CESPE/CEBRASPE. 


\begin{abstract}
This study presents an analysis about rental of physical space for the realization of civil service exams by CESPE/CEBRASPE. In this sense, the research aimed at verifying the availability of public space similar to those private spaces frequently rented by the aforementioned examing board. At first, by means of theoretical framework, was argued the main themes related to public spaces and rental expenditures for these public jobs selection exams, which are: "the concept of private and public", "rental of public space", "public budget", "civil service exams", and "quality of public spending". The current outlook of public institutions in Distrito Federal, regarding its quantum and features, was also presented. In addition, the track record of all selections made by CESPE/CEBRASPE from 2009 to 2014 was listed, discussing the features of the rented spaces, the availability of public space in Distrito Federal and the possibility of CESPE/CEBRASPE substituting private for public space for the realization of these exams. It is a qualitative case study, exploratory and descriptive nature. Primary data was collected through interviews and secondary data were collected from the School Census databases 2014 SIAFI and documents. In terms of results, it was possible to see CESPE/CEBRASPE's revenue evolution and its expenses with rental of physical space in the period from 2009 to 2014. The conclusion reached is that CESPE/CEBRASPE could prioritize the rental of public space for the exams, generating an important stream of revenue for the public sector.
\end{abstract}

Keywords: Civil service exams. Public space. Distrito Federal. CESPE/CEBRASPE. 


\section{SUMÁRIO}

AGRADECIMENTOS ........................................................................................ V

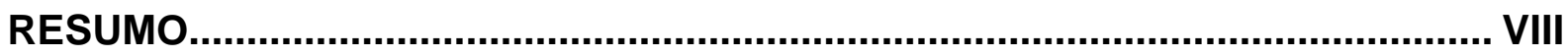

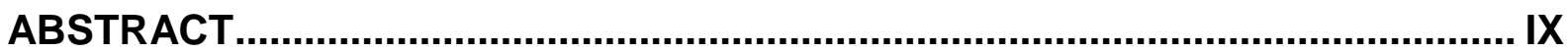

LISTA DE FIGURAS .............................................................................. XIII

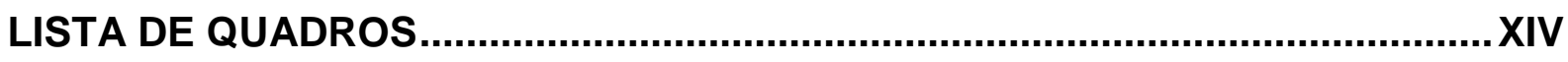

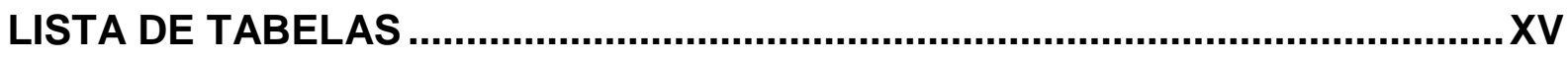

LISTA DE ABREVIATURAS E SIGLAS .....................................................XVI

1 INTRODUÇÃO ............................................................................................18

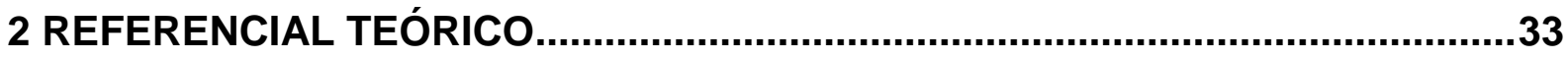

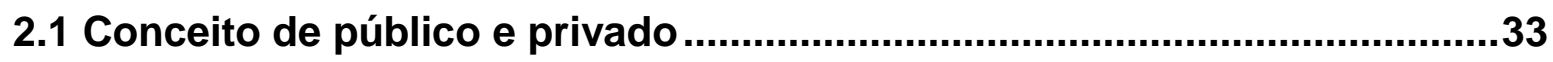

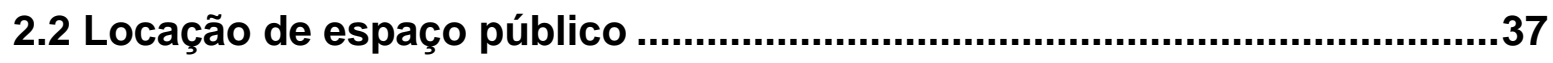

2.3 Concurso público..................................................................................47

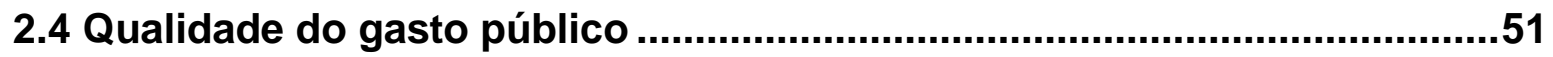

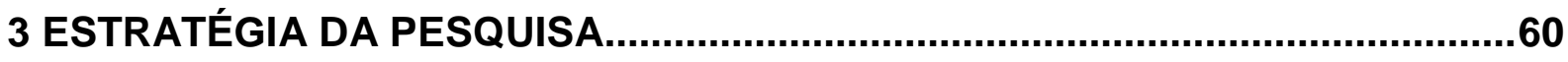

3.1 Percurso metodológico ....................................................................60

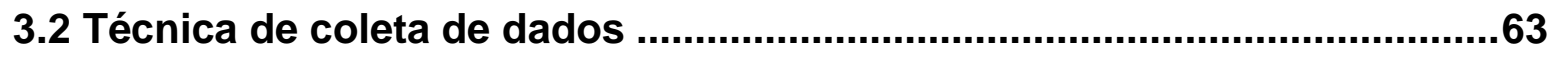

3.3 Técnica de análise dos Dados .......................................................... 71

3.4 Limitações do método ......................................................................... 76

4 RESULTADOS...................................................................................... 81

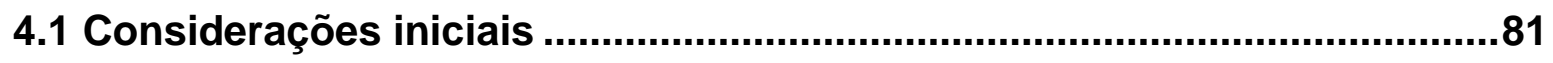

4.2 Descrição dos critérios e características utilizados pelo

CESPE/CEBRASPE para definir a contratação/locação de espaço privado

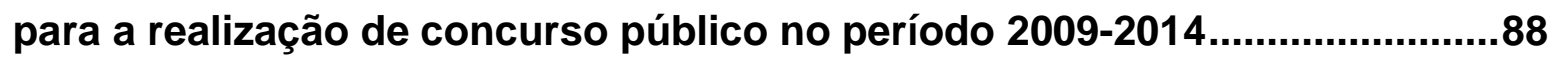


4.3 Identificar as instituições públicas e privadas do Distrito Federal utilizadas pelo CESPE para a realização de concurso público e comprara os gastos com a locação de espaço físico para a realização dos eventos entre os entes no período 2009-2014. .94

4.4 Demonstração da evolução dos recursos recebidos pelo CESPE/CEBRASPE e os gastos com locação de espaço físico para a realização de concurso público no período 2009-2014 .108

4.5 Descrição das instituições públicas com os critérios e características utilizados pelo CESPE/CEBRASPE para definir a contratação/locação de espaço para concurso público no Distrito Federal

5 CONCLUSÕES

6 RECOMENDAÇÕES .120

REFERÊNCIAS. .124

ANEXOS .141

ANEXO "A" - ESTATUTO DO CEBRASPE .142

ANEXO “B” - CONTRATO DE GESTÃO: CEBRASPE-MEC-FUB .156

ANEXO "C" - CADASTRO NACIONAL DA PESSOA JURÍDICA .168

ANEXO “D” - DOCUMENTO DO GOVERNO DE BRASÍLIA AUTORIZANDO O ACESSO ÀS DEPENDÊNCIAS DAS ESCOLAS SEM IDENTIFICAÇÃO DAS MESMAS .170

ANEXO "E” - ESCOLAS PÚBLICAS APTAS A RECEBEREM SELEÇÕES

PÚBLICAS CONFORME CRITÉRIOS ESTABELECIDOS PELO

CESPE/CEBRASPE .171

ANEXO "F" - RELATÓRIO TÉCNICO 174

ANEXO "G" - PLANO DE AÇÃO .191 
APÊNDICES

.194

APÊNDICE “A” - EXTRATO DE ENTREVISTADOS …......................................195

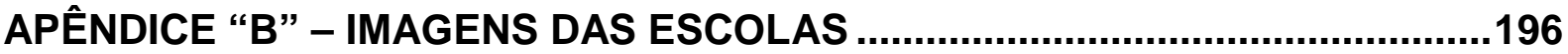




\section{LISTA DE GRÁFICOS}

Gráfico 1 - Disponibilidade de espaço público por Unidade da Federação.. 78

Gráfico 2 - Comparativo de infraestrutura básica: Brasil-Distrito FederalAmazonas........................................................... 91

Gráfico 3 - Demanda de inscritos por ano no Brasil e no Distrito Federal... 93

Gráfico 4- Demonstrativo da infraestrutura das escolas públicas e privadas da Educação Básica no Brasil............................... 99

Gráfico 5 - Demonstrativo da infraestrutura das escolas públicas e privadas da Educação Básica no Distrito Federal................... 100

Gráfico 6 - Percentual dos recursos destinados às instituições públicas e privadas no Distrito Federal........................................ 107

Gráfico 7 - Percentual dos recursos destinados às instituições públicas e privadas no Brasil.......................................................... 107

Gráfico 8 - Histórico de arrecadação do CESPE/CEBRASPE - período

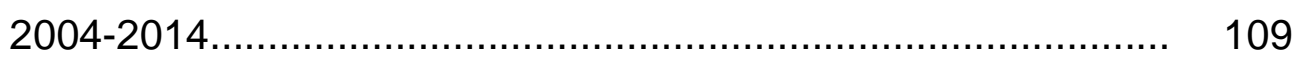

Gráfico 9 - Linha de tendência na arrecadação do CESPE/CEBRASPE período 2004-2014

Gráfico 10 - Histórico da despesa do CESPE/CEBRASPE com locação de espaço físico - período 2009-2014. 


\section{LISTA DE QUADROS}

Quadro 1 - Natureza bibliográfica dos textos utilizados na pesquisa........... 61

Quadro 2 - Perguntas para entrevista no CESPE/CEBRASPE................. 64

Quadro 3 - Lista de entrevistados.......................................... 70

Quadro 4 - Modelo analítico de pesquisa........................................ 74

Quadro 5 - Número de estabelecimentos da Educação Básica por Unidade da Federação................................................. 79 


\section{LISTA DE TABELAS}

Tabela 1 - Detalhamento de quantidade de salas por estabelecimento......

Tabela 2 - Detalhamento de quantidade de turmas e matrícula por estabelecimento..

Tabela 3 - As dez principais instituições privadas que foram locadas pelo CESPE/CEBRASPE

Tabela 4 - Número de estabelecimentos da Educação básica do Distrito Federal.

Tabela 5 - Despesa com locação de espaço público e privado no Brasil (em R\$)

Tabela 6 - Despesa com locação de espaço público e privado no Distrito Federal (em R\$) 


\section{LISTA DE ABREVIATURAS E SIGLAS}

$\begin{array}{ll}\text { ANRESC } & \text { - Avaliação Nacional de Rendimento Escolar } \\ \text { Art. } & \text { - Artigo } \\ \text { CD } & \text { - Compact Disc } \\ \text { CE } & \text { - Centro de Ensino } \\ \text { CEBRASPE } & \text { - Centro Brasileiro de Pesquisa em Avaliação e Seleção e de } \\ & \text { Promoção de Eventos } \\ \text { CEF } & \text { - Centro de Ensino Fundamental } \\ \text { CEM } & \text { - Centro de Ensino Médio } \\ \text { CESB } & \text { - Centro de Educação Superior de Brasília } \\ \text { CESPE } & \text { - Centro de Seleção e Promoção de Eventos } \\ \text { CF } & \text { - Constituição Federal } \\ \text { CGU } & \text { - Controladoria-Geral da União } \\ \text { CN } & \text { - Congresso Nacional } \\ \text { CNPJ } & \text { - Cadastro Nacional de Pessoa Jurídica } \\ \text { COPEVE } & \text { - Comissão Permanente de Concurso Vestibular } \\ \text { CPF } & \text { - Cadastro de Pessoa Física } \\ \text { DCF } & \text { - Diretoria de Contabilidade e Finanças } \\ \text { DOU } & \text { - Diário Oficial da União } \\ \text { Dr. } & \text { - Doutor } \\ \text { Dra. } & - \text { Doutora } \\ \text { ENEM } & \text { - Exame Nacional de Ensino Médio } \\ \text { ESAF } & \text { - Escola de Administração Fazendária } \\ \text { FAI } & \text { - Fundo de Apoio Institucional } \\ \text { FGV } & \text { - Fundação Getulio Vargas } \\ \text { FUB } & \text { - Fundação Universidade de Brasília } \\ \text { FUP } & \text { - Faculdade de Planaltina } \\ \text { GDF } & \text { - Governo do Distrito Federal } \\ \text { IBGE } & \text { - Instituto Brasileiro de Geografia e Estatística } \\ \text { IFB } & \text { - Instituto Federal de Brasília } \\ \text { Inc. } & \text { - Inciso } \\ \end{array}$




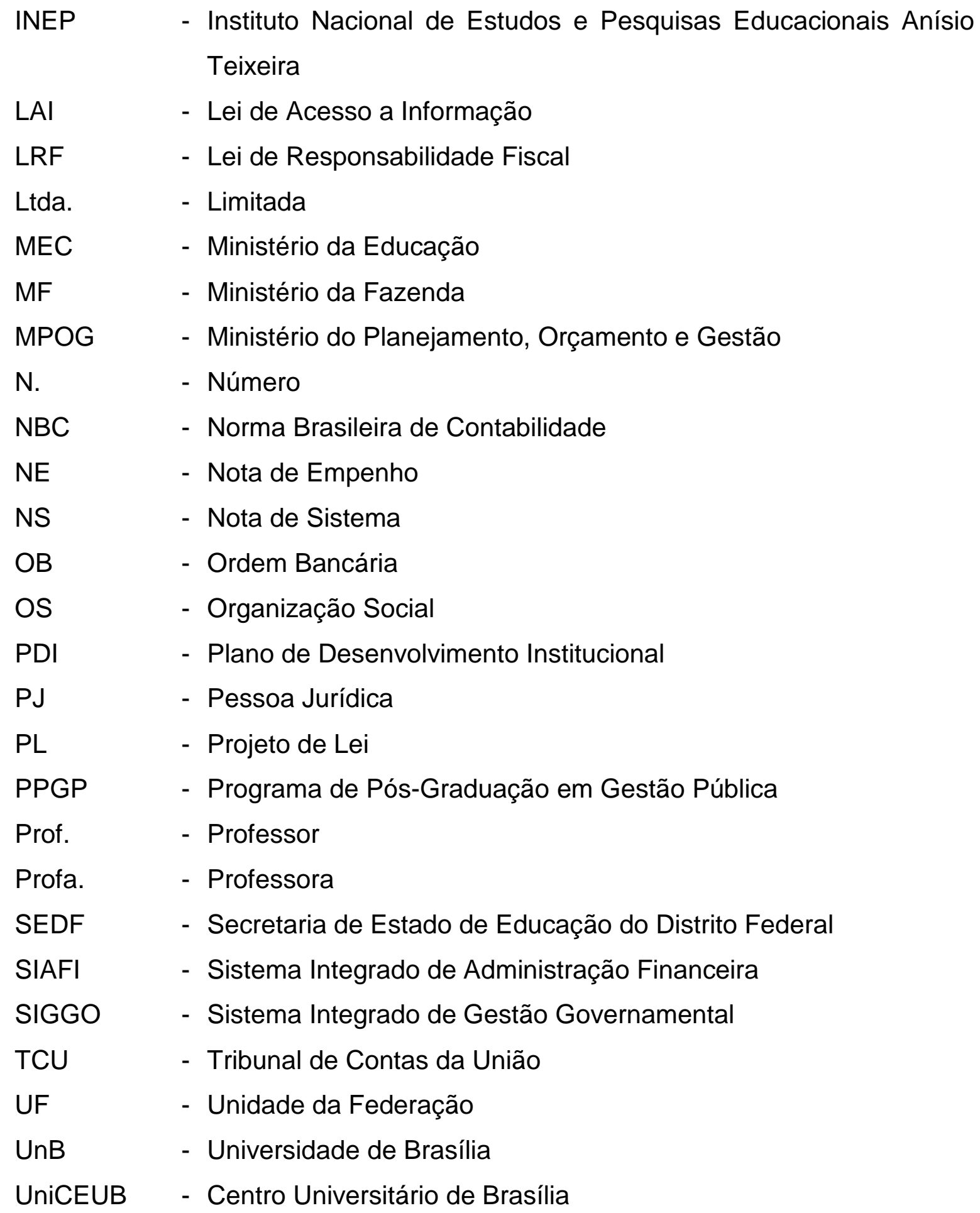




\section{INTRODUÇÃO}

No Brasil, as especificidades e os critérios para o ingresso em cargo público aparecem desde a Constituição Política do Império do Brasil, de 25 de março de 1824. Apesar de o tema "concurso público" não se fazer presente nas Constituições de 1824 e 1891, os critérios de ingresso e admissão no serviço público tiveram destaque em alguns artigos, como no art. 179 da Constituição de 1824, in verbis:

Art. 179. A inviolabilidade dos Direitos Civis, e Politicos dos Cidadãos Brazileiros, que tem por base a liberdade, a segurança individual, e a propriedade, é garantida pela Constituição do Imperio, pela maneira seguinte.

$[\ldots]$.

XIV. Todo o cidadão pode ser admittido aos Cargos Publicos Civis, Politicos, ou Militares, sem outra differença, que não seja dos seus talentos, e virtudes.

$[\ldots]$.

e nos art. 73 e art. 79 da Constituição de 1891, in verbis:

Art 73 - Os cargos públicos civis ou militares são acessíveis a todos os brasileiros, observadas as condições de capacidade especial que a lei estatuir, sendo, porém, vedadas as acumulações remuneradas.

$[\ldots]$

Art 79 - O cidadão investido em funções de qualquer dos três Poderes federais não poderá exercer as de outro.

assegurando, assim, o acesso em cargo público a todo cidadão brasileiro e vedando o acumulo de cargos e remunerações entre poderes.

A partir 1934, a Carta Magna brasileira passa a dispor sobre a previsão da acessibilidade dos cargos públicos por meio de concurso público (AGLANTZAKIS, 2003). A previsão do art. 170 , § $2^{\circ}$, in verbis: 
Art 170 - O Poder Legislativo votará o Estatuto dos Funcionários Públicos, obedecendo às seguintes normas, desde já em vigor:

$[\ldots]$;

$\left.2^{\circ}\right)$ a primeira investidura nos postos de carreira das repartições administrativas, e nos demais que a lei determinar, efetuar-se-á depois de exame de sanidade e concurso de provas ou títulos;

$[\ldots]$.

deu início a um novo modelo de ingresso no serviço público.

Com o advento da Constituição Federal (CF) de 1988 - aquela que mais trouxe inovações sobre o tema -, tornou-se obrigatória a prévia aprovação em concurso público para investidura em cargo ou emprego público, com algumas exceções (AGLANTZAKIS, 2003). Tal obrigatoriedade está correlacionada a um dos objetivos fundamentais estabelecidos na Carta Magna de 1988: a construção de uma sociedade livre, justa e solidária. Pois, uma das finalidades da seleção pública é minimizar as desigualdades entre cidadãos brasileiros, oferecendo-lhes as mesmas condições para exercerem seus direitos.

Destarte, como consequência do princípio democrático e a construção de uma sociedade mais justa, a CF de 1988 ratificou a obrigatoriedade de concurso público, bem como suas exceções, em seu art. 37, inc. II, in verbis:

Art. 37. A administração pública direta e indireta de qualquer dos Poderes da União, dos Estados, do Distrito Federal e dos Municípios obedecerá aos princípios de legalidade, impessoalidade, moralidade, publicidade e eficiência e, também, ao seguinte: (Redação dada pela Emenda Constitucional n. 19, de 1998)

$[\ldots]$;

II - A investidura em cargo ou emprego público depende de aprovação prévia em concurso público de provas ou de provas e títulos, de acordo com a natureza e a complexidade do cargo ou emprego, na forma prevista em lei, ressalvadas as nomeações para cargo em comissão declarado em lei de livre nomeação e exoneração (Redação dada pela Emenda Constitucional n. 19, de 1998)

[...]. 
Com a exigência de concurso público para ingresso no serviço público e o aumento da população brasileira que, segundo dados do Instituto Brasileiro de Geografia e Estatística (IBGE) (2014a), passou de 146.917.459 habitantes, em 1990, para 202.033.670 em 2014 (ou seja, um aumento de mais de 27\% da população), cresceu também a demanda pelos serviços públicos e a estrutura administrativa teve que acompanhar a evolução com a criação de mais instituições públicas e, consequentemente, o aumento de seleções públicas para contratação de pessoal.

De acordo com dados do Boletim Estatístico de Pessoal (BRASIL, 2015), a população de servidores públicos em todos os poderes da União passou de 1.836.251, em 1995, para 2.124.404, em 2013. O crescimento de servidores públicos não se deu apenas na esfera federal. A evolução também pode ser vista nos Estados, nos Municípios e no Distrito Federal, onde este último, por exemplo, segundo dados do IBGE (2014b) referentes ao Sistema Integrado de Gestão Governamental do Distrito Federal (SIGGO), somente em 2013, recebeu mais de 45 mil novos funcionários públicos e passou a marca de 190 mil servidores públicos (entre ativos e inativos), com gasto de pessoal que ultrapassa 8,1 bilhões de reais. Porém, apesar da obrigatoriedade do concurso público desde 1988, nem sempre o serviço público foi atrativo para o cidadão brasileiro, bem como, em algumas gestões, a seleção pública não foi priorizada.

Em relação aos governos, é possível comparar 02 (dois) tempos distintos, um primeiro período de 1995 a 2002 e um segundo momento de 2003 a 2010, pois de acordo com o Boletim Estatístico de Pessoal do Ministério do Planejamento, Orçamento e Gestão (MPOG) (BRASIL, 2015), no primeiro, houve 51.613 ingressos no serviço público, enquanto que no segundo período, o ingresso no serviço público 
federal totalizou 155.533, ou seja, um dos governos optou em fortalecer o quadro de pessoal estatal, tendo em vista que o segundo ingressou $201,35 \%$ servidores públicos a mais do que o primeiro.

Além disso, no período de 1995 a 2002 tem-se uma linha decrescente de ingresso no serviço público, pois, de 1999 a 2002, apenas 5.141 pessoas ingressaram no serviço público, sendo 2.927 em 1999, 1.524 em 2000, 660 em 2001 e apenas $30 \mathrm{em}$ 2002. Um total inferior ao primeiro ano do governo que iniciou-se em 2003, que contratou, apenas neste exercício, 7.220 novos servidores federais.

Tal evolução no quadro de servidores públicos gerou um aumento significativo nos concursos públicos e, consequentemente, no número de bancas organizadoras de concursos/seleções públicas. Isto posto, conforme dados levantados junto ao Centro de Seleção e Promoção de Eventos/Centro Brasileiro de Pesquisa em Avaliação e Seleção e de Promoção de Eventos (CESPE/CEBRASPE), que a partir de 2014 passou a ser uma Organização Social (OS) e se chamar CESPE/CEBRASPE, realizou, de 2009 a 2014, 320 seleções públicas no Brasil, destacando-se como uma das maiores bancas examinadoras do país (PATI, 2013).

Diante do crescimento do quadro de servidores públicos em todas as esferas de governo e do aumento significativo de despesa com pessoal, em 2000 foi publicada a Lei Complementar n. 101, denominada Lei de Responsabilidade Fiscal (LRF), que trouxe todo um capítulo dispondo sobre a despesa com pessoal, inclusive, em seu art. 19, estabelecendo limites para a União, os Estados, os Municípios e o Distrito Federal, in verbis:

Art. 19. Para os fins do disposto no caput do art. 169 da Constituição, a despesa total com pessoal, em cada período de apuração e em cada ente da Federação, não poderá exceder os percentuais da receita corrente líquida, a seguir discriminados:

I - União: 50\% (cinquenta por cento); 
II - Estados: 60\% (sessenta por cento);

III - Municípios: $60 \%$ (sessenta por cento).

Por conseguinte, o aumento do número de concursos públicos em toda esfera de governo demandaram a criação de muitas instituições especializadas na organização de seleção pública, de modo que, nos últimos anos, conforme o site Concursos no Brasil (2015), já se ultrapassou a marca de 590 bancas organizadoras de concursos registradas no País.

O mercado "concurso público" tem crescido desordenadamente no Brasil e, como as casas legislativas têm discutido sobre a matéria com o objetivo de estabelecer normas gerais para realização dos certames, faz-se importante pesquisar a existência de espaço público disponível, que possuam as mesmas características dos espaços privados atualmente contratados pelas bancas organizadoras, para que tais espaços também possam ser aproveitados nas seleções públicas.

Em meio às principais bancas organizadoras de concurso público, destacamse no cenário nacional: o CESPE; a Fundação Getulio Vargas (FGV); a Escola de Administração Fazendária (ESAF); a Fundação CESGRANRIO, entre outras. Vale destacar que o CESPE/CEBRASPE é a instituição que realiza boa parte dos principais concursos públicos do país, com mais de 320 seleções públicas divulgadas no Diário Oficial da União (DOU), de 2009 a 2014, com arrecadações anuais que chegaram à aproximadamente $\mathrm{R} \$ 400.000 .000,00$ (quatrocentos milhões de reais), conforme levantamento feito no Portal da Transparência e o Sistema Integrado de Administração Financeira do Governo Federal (SIAFI) (PATI, 2013).

Devido ao volume de arrecadação supramencionado, em pouco tempo, o CESPE consolidou-se como a maior unidade geradora de recursos da Fundação Universidade de Brasília (FUB), de fundamental importância para o crescimento da 
instituição, tendo em vista que aquele primeiro representa a maior percentual de recursos próprios da Universidade de Brasília (UnB), mesmo que cerca de 85\% dos recursos arrecadados sejam gastos com a execução das suas próprias atividades (LIMA; LIMA FILHO, 2008).

A significância do CESPE no desenvolvimento das atividades da FUB passou a ser destaque nos próprios documentos de gestão publicados pela instituição. Conforme o Relatório de Gestão de 2010 (UnB, 2011, p. 33), já era apresentado da seguinte forma:

Cumpre informar que a arrecadação da FUB por meio de recursos próprios complementa o desenvolvimento das suas atividades, sendo o CESPE responsável por mais de $70 \%$ da arrecadação institucional com importante contribuição no pagamento de despesas de encargos gerais.

$\mathrm{Na}$ capital federal, de 2009 a 2014, conforme dados apurados junto ao CESPE, por meio das Ordens Bancárias consultadas no SIAFI e a lista de instituições utilizadas com frequência fornecida por este Centro, os eventos têm sido realizados, em sua maioria, nas dependências de instituições de ensino privado e pouco se tem utilizado o espaço público disponível, o que pode acarretar no aumento do Escopo da contratação.

A exemplo disso, em consulta ao SIAFI e Portal da Transparência do Governo Federal, observou-se que o CESPE/CEBRASPE, de janeiro de 2009 a dezembro de 2014, gastou com locação de espaço físico mais de $\mathrm{R} \$ 53.700 .000,00$ (cinquenta e três milhões e setecentos mil reais), sendo que desse valor, 83\% (mais de $\mathrm{R} \$$ 44.000.000,00 - quarenta e quatro milhões de reais) foi destinado a locação apenas de instituições privadas - em Brasília, tal percentual passa dos 95\% (mais de $\mathrm{R} \$$ 8.700.000,00 - oito milhões e setecentos mil reais). Neste sentido, é possível questionar: será que tal recurso poderia ter sido destinado às instituições de ensino 
público? E ainda: será que o Distrito Federal possui espaço público disponível e com as mesmas características dos espaços privados locados pelo CESPE/CEBRASPE.

A frequente seleção das mesmas instituições de ensino privadas e a baixa procura pelos espaços públicos podem despertar alguns questionamentos, como, por exemplo: qual seria o critério adotado pelo CESPE/CEBRASPE para locar um espaço físico? Vale destacar que, conforme o Censo Escolar 2014 (INEP, 2014), somente no Distrito Federal, existem 664 instituições de ensino públicas, seja distrital ou federal; logo, estas poderiam locar ou ceder seus espaços para a realização de concursos públicos caso tenham as mesmas características dos espaços privados locados pelo CESPE/CEBRASPE. Assim, é preciso investigar se tais espaços são utilizados ou se as instituições de ensino público não possuem estruturas adequadas para locar seus espaços físicos.

Eventos de grande porte operados pelo CESPE/CEBRASPE, como, por exemplo, a Avaliação Nacional de Rendimento Escolar (ANRESC) (também conhecida como "Prova Brasil") e o Exame Nacional de Ensino Médio (ENEM), evidenciam que as instituições de ensino público do Distrito Federal estão aptas a cederem seus espaços para a realização de concursos públicos/seleções públicas. Todavia, faz-se importante investigar se tais instituições de ensino recebem recursos pela locação/cessão do seu espaço físico e se as características dos referidos espaços são similares aos espaços privados, haja vista que tão relevante quanto identificar se as instituições públicas recebem recursos financeiros para a realização de eventos é apontar se o espaço público disponível no Distrito Federal pode substituir o espaço privado contratado com frequência pelo CESPE/CEBRASPE. 
Neste contexto, no intuito de otimizar a utilização de recursos públicos, faz-se importante investigar a melhor locação do espaço para a realização de certames públicos. Para tanto, importa o presente estudo, que analisou a forma que o CESPE/CEBRASPE loca o espaço físico das instituições privadas, qual a justificativa da não utilização de todo o espaço público disponível, qual o critério utilizado na seleção do espaço, bem como seu impacto nos custos da contratação. E ainda, objetivou-se aqui investigar se instituições de ensino público no Distrito Federal podem substituir o espaço privado utilizado por aquele Centro de Seleção para a realização de concurso público, apresentando os espaços públicos e privados da referida Unidade da Federação (UF), as receitas e os gastos do CESPE/CEBRASPE com a execução dessas seleções públicas e o espaço público disponível no Distrito Federal apto a receber os referidos eventos.

Segundo Carvalho e Tonet (1994), a Administração Pública brasileira encontra-se em crise. É necessário discutir sobre a perda de eficiência no serviço público, pois, é nítido o sucateamento dos serviços essenciais ao interesse público. Contudo, a realização de pesquisas que possam vir a contribuir com a melhoria dos serviços prestados ao cidadão é de fundamental importância para que o Estado possa atender suas demandas de forma eficiente e eficaz.

O concurso público está diretamente ligado aos serviços prestados à sociedade. Tal modalidade de licitação é utilizada para dar provimento ao cidadão aos cargos da Administração Pública. A contratação de bancas organizadoras e a execução dos serviços das mesmas envolvem recursos públicos e necessitam ser fiscalizados pela sociedade, de forma a segurar a transparência e qualidade do gasto público. 
A utilização de instituições públicas para a realização de concursos públicos ao invés de privadas, pode ser uma forma das referidas instituições arrecadarem recursos e otimizar seus espaços em períodos ociosos, haja vista que tais instituições, mesmo quando não utilizadas, como, por exemplo, nos finais de semanas, geram custos (que fazem parte das despesas totais com o ensino no País) para o Estado.

Para Silva Filho (2008), a educação é determinante para o desenvolvimento do Estado. Logo, a problematização da pesquisa traz o seguinte questionamento: as instituições de ensino público no Distrito Federal podem substituir o espaço privado utilizado pelo CESPE/CEBRASPE para realização de concurso público?

Assim, em relação ao problema supramencionado, têm-se as seguintes hipóteses diretrizes ${ }^{1}$ :

1. O CESPE destina recursos financeiros para as instituições públicas que locam/cedem seu espaço para a realização de concursos públicos;

2. Há disponibilidade de espaço público em instituições públicas de ensino do Distrito Federal para realização de concurso público organizado pelo CESPE;

3. As instituições de ensino público estão preparadas para locar seus espaços físicos, para a realização de concursos, conforme as características mínimas exigidas pelo CESPE.

4. Há critério adotado pelo CESPE para locar um espaço físico; e

5. Tornar obrigatório que os concursos públicos, realizados por organizações públicas, prioritariamente, ocorressem em espaços públicos é uma forma de captação de recursos das instituições públicas.

\footnotetext{
${ }^{1}$ Segundo Hirano (1979), a hipótese Diretrizes é uma verdade provisória, uma resposta antecipada ao problema de pesquisa, que serve para vincular teoria ao fato e guiar a busca e a interpretação dos dados, e que só se transformam num novo conhecimento se os dados obtidos a confirmam.
} 
Segundo Gil (2010, p. 18), as hipóteses podem se apresentar em diferentes níveis de formulação - algumas casuísticas (que se referem a algo que ocorre em determinado caso) e outras capazes de descrever um fenômeno. Para aquele autor, estas últimas "são as que mais interessam a investigação científica" (GIL, 2010, p. 8) e correspondem à definição proposta por Kerlinger (1980, p. 38): "uma hipótese é um enunciado conjectural das relações entre duas ou mais variáveis".

Tais hipóteses tornam-se vertentes para a análise dos espaços de serventia para a realização de concurso público, bem como aventam a possibilidade de substituição do espaço privado para as instituições públicas de ensino.

Por conseguinte, o presente estudo buscou analisar se as instituições de ensino público no Distrito Federal podem substituir os espaços privados utilizados pelo CESPE/CEBRASPE para a realização de concurso público.

Em especial buscou-se:

a) Descrever os critérios e características utilizados pelo CESPE para definir a contratação/locação de espaço privado para a realização de concurso público no período 2009-2014;

b) Identificar as instituições públicas e privadas do Distrito Federal utilizadas pelo CESPE para a realização de concurso público e comparar os gastos com a locação de espaço físico para realização dos eventos entre os entes no período 2009-2014;

c) Demonstrar a evolução dos recursos captados pelo CESPE e os gastos com locação de espaço físico para realização de concurso público no período 2009-2014; 
d) Descrever as instituições públicas de ensino com os critérios e características utilizadas pelo CESPE para definir a contratação/locação de espaço para concurso público no Distrito Federal; e

e) Apresentar a forma de contratação, a modalidade de licitação e as justificativas do CESPE para locação de espaço físico para realização de concurso público no período 2009-2014.

Diante do exposto, o presente estudo foi motivado devido ao crescente aumento do mercado "concurso público" no Brasil, tendo em vista que, conforme o site Concursos no Brasil (2015), já se ultrapassou a marca de 590 bancas organizadoras de concursos. O crescente quantitativo de bancas torna-se relevante tanto pela fragilidade da norma para a realização da contratação destas como pela falta de sigilo e segurança que algumas bancas proporcionam nos certames, o que pode acarretar em prejuízos irreparáveis para a sociedade e todas as esferas da Administração Pública.

É preciso ressaltar que, atualmente, as organizadoras de concursos contratadas pelo governo locam o espaço privado para a realização dos certames, acarretando no gasto de milhões de reais por ano com tal despesa. Para se ter uma ideia do volume dessa despesa, somente o CESPE/CEBRASPE e a ESAF, de janeiro de 2009 a dezembro de 2014, gastaram cerca de $\mathrm{R} \$ 54.500 .000,00$ (cinquenta e quatro milhões e quinhentos mil reais) com locação de espaço físico, sendo que o CESPE gastou mais de $R \$ 53.700 .000,00$ (cinquenta e três milhões e setecentos mil reais) e a ESAF cerca de $R \$ 778.000,00$ (setecentos e setenta e oito mil reais). 
Além disso, os estudos que abordam o concurso público no Brasil, como o de Fontainha et al. (2014), Por Exemplo, tem por norte os métodos de seleção, o sistema de arrecadação com as taxas de inscrições para participação na seleção ou sobre o mercado milionário de cursos preparatórios que foi instaurado no país. Logo, é necessário que haja também estudos quanto à logística para execução dos concursos públicos, pois a realização do evento também demanda uma enorme alocação de esforços e recursos que devem ser investigados.

Por isso, é necessário investigar se há espaço público disponível no Distrito Federal para a realização de concursos públicos que atendam os critérios mínimos estabelecidos pelo CESPE/CEBRASPE para contratação, uma vez que tal possibilidade, pode acarretar na redução do escopo da contratação, na otimização do gasto público, bem como abre a possibilidade da instituição pública na arrecadação de valores com a locação do seu espaço em períodos ociosos. Logo, havendo a possibilidade de locação de espaço público para a realização de concurso, trata-se de milhões de reais injetados nas instituições de ensino públicas do país.

Assim, as instituições públicas, possuindo espaço suficiente e adequado para realizar os concursos públicos e, comprovando a viabilidade de obtenção de recursos por meio da locação, tornam viáveis os incentivos de uma competição entre as mesmas, uma vez que todas teriam interesse em locar seu espaço. A competitividade poderia trazer, inclusive, melhorias na prestação do serviço público, pois, segundo Secchi (2009, p. 354), a Administração Pública gerencial ou nova gestão pública (new public management) "é um modelo normativo pós-burocrático para a estruturação e a gestão da Administração Pública baseado em valores de eficiência, eficácia e competitividade". 
Por isso, a pesquisa pode ser utilizada como base para fortalecer algum Projeto de Lei (PL) que torne obrigatório, ou pelo menos preferencial, a utilização do espaço público para a realização dos concursos públicos/das seleções públicas, tendo em vista que recentemente entrou em vigor a Lei Distrital n. 4.949/2012, denominada Lei Geral dos Concursos, mas que não dispõe do tema a ser pesquisado, e que hoje se encontra em discussão em ambas as casas do Congresso Nacional (CN), a aprovação de uma Lei específica que regulamenta o concurso público em âmbito federal.

Finalizando, o locus da pesquisa é o Centro de Promoção de Eventos CESPE, que tem sua história iniciada na década de 1970, com a criação da Comissão Permanente de Concurso Vestibular (COPEVE) da UnB e o início dos vestibulares semestrais (CAMPOS, 2011). Fundado em 14 de dezembro de 1993 pelo Ato da Reitoria n. 1.777, vinculado ao gabinete do Reitor, o CESPE foi criado para executar os processos de seleção de estudantes para o ingresso na Universidade e realizar concursos públicos, processos seletivos e avaliações educacionais (QUEIROGA, 2009; LIMA; LIMA FILHO, 2008).

A história do CESPE se confunde com a história dos vestibulares na UnB (LIMA; LIMA FILHO, 2008). Porém, com o passar dos anos o órgão analisado se tornou a maior banca examinadora de concursos do Brasil, celebrando contratos e convênios com entidades públicas e privadas, para realizar inúmeras atividades técnicas especializadas, como, por exemplo, a elaboração e realização de concursos públicos, vestibulares e avaliações educacionais em todo o País (LIMA; LIMA FILHO, 2008). 
Em pouco tempo, o CESPE passou a ser a maior unidade geradora de recursos da UnB e de fundamental importância para o crescimento da instituição, tendo em vista que tal órgão representa a maior percentual de recursos próprios da UnB, mesmo que cerca de $85 \%$ dos recursos arrecadados sejam gastos com a execução das suas próprias atividades (LIMA; LIMA FILHO, 2008).

Para se ter uma ideia da importância do CESPE para a UnB, principalmente quanto aos recursos transferidos, somente no exercício de 2014, mesmo não sendo um dos melhores anos de arrecadação daquele órgão, foram transferidos recursos financeiros no montante aproximado de $\mathrm{R} \$ 42.000 .000,00$ (quarenta e dois milhões de reais) para auxílio no custeio da UnB, conforme destaca o Relatório de Gestão da UnB de 2014. Contudo, mesmo sendo a principal unidade arrecadadora da UnB, o CESPE deixou de fazer parte de sua estrutura e virou uma OS, passando a ser CEBRASPE, justificada pela Gestão da UnB conforme se segue:

\footnotetext{
Durante 20 anos, a atuação do Centro de Seleção e Promoção de Eventos da Universidade de Brasília (CESPE/UnB) foi suficiente para atender às demandas de diversas seleções e eventos em âmbito nacional. No entanto, tendo em vista um aumento da demanda por eventos e seleções, a Instituição necessitava de um processo de expansão, para que sua finalidade fosse atendida. Em 19 de agosto de 2013, a Presidenta Dilma Rousseff assinou o Decreto n. ${ }^{\circ}$ 8.078, que qualificou o Centro Brasileiro de Pesquisa em Avaliação e Seleção e de Promoção de Eventos (CEBRASPE), denominado CESPE/UnB, como Organização Social (OS), permitindo que o Centro continuasse a desenvolver as atividades com os mesmos valores de qualidade, competência, isonomia, segurança e transparência que se tornaram destaque da Instituição (UnB, 2015b).
}

Assim, já no final de 2014, o CESPE passou a ser o CEBRASPE, porém, ainda fazendo uso da marca CESPE, pois, a mesma já estava inserida no mercado, passando, então, a apresentar-se como CESPE/CEBRASPE, sendo regido por um Estatuto próprio (vide Anexo "A") e um Contrato de Gestão (vide Anexo "B") com a 
FUB, por intermédio do Ministério da Educação (MEC), porém, com um quadro de servidores formado por colaboradores e técnicos da UnB.

Salienta-se que, passando o CESPE/CEBRASPE a ser uma OS, o presente estudo, quanto à locação ou utilização do espaço público para a realização de concurso público/seleção pública tornou-se ainda mais relevante, pois, conforme dispõe a Lei n. 9.637/1998, em seu art. $2^{\circ}$, é requisito especifico de uma OS ter finalidade não lucrativa e atender o interesse da sociedade. Neste sentido, a utilização de um espaço público poderia tanto reduzir as despesas da realização do evento/da seleção (ou o escopo da contratação pelo órgão público), bem como destinar recursos para as instituições de ensino públicas do Distrito Federal.

Na perspectiva de tornar agradável a leitura desta dissertação, o texto está organizado da seguinte forma: esta introdução, a segunda parte com referencial teórico que discorre sobre os temas Público/Privado e como este conceito evoluiu ao longo dos anos. Discute-se também o tema concurso público e o seu crescimento ao longo dos anos. Ao propor a discussão sobre a qualidade do gasto, de que forma pode-se pensar sobre a otimização do uso dos recursos financeiros para realização de concurso público.

A terceira parte da dissertação apresenta a estratégia de pesquisa com todos os elementos necessários para organizar a resposta da questão de pesquisa. Na quarta parte da dissertação apresenta-se os resultados e sua discussão. As conclusões encontram-se na quinta parte do trabalho.

Por fim, as recomendações estão organizadas na sexta parte do trabalho e as referências com os anexos e apêndices encontram-se organizados ao final. 


\section{REFERENCIAL TEÓRICO}

Para Vergara (2005, p. 34), o referencial teórico é "uma revisão da literatura existente, no que concerne não só ao acervo de teorias e a suas críticas, como também a trabalhos realizados que as tomam como referência". Assim, este capítulo discorre conceitos relevantes para fomentar as argumentações da pesquisa.

O referencial teórico apresentado a seguir foi organizado abordando, em um primeiro momento, o conceito de público e privado e a forma de locação do espaço público. Em seguida, tem-se a questão do concurso público como modalidade de licitação para o provimento de cargos e funções públicas no Brasil. Por fim, conceitua-se a qualidade no gasto público com base nas despesas com a locação de espaço físico realizadas por meio de dispensa de licitação.

\subsection{Conceito de público e privado}

A ideia de público e privado é debatida desde a Grécia antiga, tendo mudado de significado ao longo do tempo e tornado o debate cada vez mais intenso, devido à complexidade das sociedades no mundo moderno.

Entre as reflexões entre a esfera pública e a esfera privada, destacam-se as ideias expostas por Hannah Arendt - filósofa que está no centro de grandes polêmicas do século XX. Arendt (2008, p. 31) afirma que "todas as atividades humanas são condicionadas pelo fato de que os homens vivem juntos; mas a ação é a única que não pode sequer ser imaginada fora da sociedade dos homens". 
Por conseguinte, nota-se que o processo de formação do ser humano, da sociedade, bem como o processo de socialização da família às instituições são inseridos no conceito de público e privado. Pois, segundo Arendt (1983, p. 48), tais fatores geram o atual estabelecimento desses espaços:

O que hoje chamamos de privado é um círculo de intimidade cujos primórdios podemos encontrar nos últimos períodos da civilização romana, embora dificilmente em qualquer período da antiguidade grega, mas cujas peculiares multiformidades e variedade eram certamente desconhecidas de qualquer período anterior à era moderna.

Contudo, é necessário considerar 02 (duas) acepções do termo "púbico", introduzidas por Arendt (1983, p. 59): a primeira, "tudo o que vem a público pode ser visto e ouvido por todos, e tem a maior divulgação possível. Para nós, a aparência aquilo que é visto e ouvido pelos outros e por nós mesmos - constitui a realidade"; e, a segunda,

\begin{abstract}
O termo público significa o próprio mundo, à medida que é comum a todos nós e diferente do lugar que nos cabe dentro dele. Este mundo, contudo, não é idêntico à terra ou à natureza como espaço limitado para o movimento dos homens e condição geral da vida orgânica. Antes, tem a ver com o artefato humano, com o produto de mãos humanas, com os negócios realizados entre os que, juntos habitam o mundo feito pelo homem [...]. A esfera pública, enquanto mundo comum, reúne-nos na companhia uns dos outros e, contudo, evita que colidamos uns com os outros, por assim dizer (ARENDT, 1983, p. 62).
\end{abstract}

Segundo Arendt (2008, p. 38), "historicamente, é muito provável que o surgimento da cidade-estado e da esfera pública tenha ocorrido às custas da esfera privada da família e do lar".

Para Pinto e Costa (2015, p. 312), o histórico estatal brasileiro é vestido justamente pelas dificuldades de distinguir os interesses privados de interesses públicos; ou seja, "observa-se, sobretudo na herança do período colonial e ao longo da república velha, a caracterização de um modelo patrimonialista, em que se 
confundindo o público e o privado, havia forte presença de corrupção, clientelismo e nepotismo".

Por isso, ao dispor sobre o conflito entre o público e o privado, faz-se importante salientar que seus desdobramentos efetivos estão vinculados a inúmeras determinações estruturais e conjunturais de uma realidade sócio-político-cultural do país. Isto posto, segundo Pinto e Costa (2015), o início da República Velha, com a Proclamação da República em 1889, e o estabelecimento da segunda Constituição em 1891, foram determinantes para cultura política brasileira dominar a estrutura estatal.

Neste sentido, Pinto e Costa (2015, p. 312) destacam:

\begin{abstract}
Já no século XX, observou-se a transição do modelo patrimonialista para o modelo burocrático, mormente a partir da Era Vargas com a criação do Departamento Administrativo do Serviço Público. Este modelo destacou-se pelas ideias de impessoalidade e racionalismo, contudo, ficou caracterizado por um Estado mais lento e ineficiente. Na década de 1990, executou-se uma reforma no aparelho estatal brasileiro, com o intuito de torná-lo mais eficiente e organizado e que, nos dizeres de Bresser-Pereira (2013, p. 9), foi "[...] a segunda reforma do Estado moderno. A primeira possibilitou a transição de um Estado patrimonialista para um Estado burocrático e liberal".
\end{abstract}

Por conseguinte, historicamente, as esferas públicas e privadas sofreram um processo de difícil distinção. Pois, "ainda no império, quando a legislação da metrópole portuguesa regia as relações entre os elementos constitutivos da colônia e as relações de direito privado, de outro lado, na esfera do público, destacava-se o poder onímodo dos governadores proprietários" (PINTO; COSTA, 2015, p. 315).

Neste período destacou-se a interferência do setor privado nos assuntos entre a metrópole e a colônia, por sua vez, usurpando funções públicas. Privatismo e arbítrio se confundem numa conduta de burla à autoridade, perdida esta na ineficiência. Este descompasso cobrirá, por muitos séculos, o exercício privado de funções públicas e o exercício público de atribuições não legais. O déspota colonial e o potentado privado têm aí suas origens, origens que o tempo consolidará (FAORO, 2001, p. 214). 
Para Bandeira de Mello (1975), o público e o privado assumem conotações diversificadas, dependendo do olhar que lhes é lançado. Contudo, quando caracterizadas no jurídico-formal, tais termos se vinculam a explicitação do regime jurídico.

Saber se uma atividade é pública ou privada é mera questão de indagar do regime jurídico a que se submete. Se o regime que a lei lhe atribui é público, a atividade é pública; se o regime é de direito privado, privada se reputará a atividade, seja, ou não, desenvolvida pelo Estado. Em suma: não é o sujeito da atividade, nem a natureza dela que Ihe outorgam caráter público ou privado; mas o regime a que, por lei, for submetida (BANDEIRA DE MELLO, 1975, p.14).

O conceito de público e privado se estende aos espaços. Segundo Matos (2010), o conceito de espaço público é relativamente recente, porém, quando se discorre sobre a vida familiar, em vida privada, ou no alojamento, nunca se impugna uma noção genérica de espaço público. Conforme Ascher (1998, p. 172), "a expressão espaço público, surge em França, pela primeira vez em meados dos anos 70 e conhecerá um êxito crescente, fruto, em parte, de uma nova abordagem da cidade em que se passa a valorizar a requalificação em vez da reabilitação".

\begin{abstract}
O espaço público tem uma função e esta pressupõe um uso, a essência do espaço público está na forma como este é utilizado pelos actores sociais, ou seja, das práticas que possa acolher, que torna possível ou até favorece, podendo a sua forma, favorecer ou inibir essas práticas. Este uso já não se faz só em função das dimensões objectivas dos indivíduos, isto é, idade, género, habilitações, classe social, estilo de vida, etc., mas cada vez mais incorporam outros aspectos mais subjectivos, como as motivações, as aspirações e os valores dos indivíduos. A dimensão simbólica, ganha mais força, os espaços passam a ser utilizados também pela sua imagem, qualidade e conforto (MATOS, 2010, p. 20).
\end{abstract}

A esfera privada é o oposto e o complemento da esfera pública. Entende-se como esfera privada o setor determinado da vida em sociedade onde um indivíduo goza de certo grau de autoridade, livre de intervenções governamentais ou de outras 
instituições. Contudo, não se pode confundir lugar público com espaço acessível ao público (ou aberto ao público), e tampouco confundir o espaço privado como os locais inacessíveis ao público e que ferem o direito de ir e vir.

O espaço privado é o espaço da propriedade privada, da família, do particular. Todavia, atualmente tais espaços se confundem e mantêm uma relação complementar com os espaços públicos. Segundo Miyamoto e Krohling (2012), com base na reflexão de Hannah Arendt (2008), o espaço privado é entendido como o símbolo de intimidade, de privacidade que se opõe ao espaço público, bélico em sua natureza, dos embates políticos, ao desvelar que privado, na sua acepção original, significa privação, ou seja, de ser privado de sua própria existência, vez que destituído de coisas essenciais à vida verdadeiramente humana.

\subsection{Locação de espaço público}

Tem-se a questão da locação de espaço público no Brasil como algo há um bom tempo em discussão. Algumas Unidades da Federação (UFs), como, por exemplo, Rio Grande do Sul, Santa Catarina e São Paulo, editaram leis específicas sobre a concessão ou permissão do uso dos espaços públicos. Do mesmo modo, tal ação também se deu em muitos Municípios, que também passaram a instituir normas que tratavam sobre o referido tema.

Os Estados e Municípios regulamentam esta matéria por que, de acordo com a Constituição Federal (CF) de 1988, em seu art. 24, in verbis:

Art. 24. Compete à União, aos Estados e ao Distrito Federal legislar concorrentemente sobre:

I - direito tributário, financeiro, penitenciário, econômico e urbanístico;

[...]. 
A questão do urbanismo é definida por Hely Lopes Meirelles (2007, p. 511) como "um conjunto de medidas estatais destinadas a organizar os espaços habitáveis, de modo a propiciar melhores condições de vida ao homem na comunidade". Por conseguinte, aquele autor conceitua o direito urbanístico como "o ramo do direito público destinado ao estudo e formulação dos princípios e normas que devem reger os espaços habitáveis, no seu conjunto cidade-campo" (MEIRELLES, 2007, p. 513).

Neves (2008) destaca 02 (duas) questões primordiais a serem abordadas pelo tema, quais sejam: 1) qual a forma administrativa de utilização do espaço público; e, 2) se há ou não a necessidade de licitação para tal uso. Neste sentido, é preciso entender de que forma os espaços públicos poderiam ser utilizados por terceiros, bem como qual seria a forma correta da contratação.

É sabido que os bens públicos tem como função primordial o atendimento do interesse imediato da Administração Pública. Porém, não há impedimento legal para que os mesmos possam ser utilizados por terceiros, tendo como instrumentos possíveis para o feito os que se seguem: a autorização de uso, a permissão de uso, a concessão de uso, a cessão de uso e a concessão de direito real de uso.

O art. 22 da Lei n. 9.636/1998 - regulamentado pelo art. 14 do Decreto n. 3.725/2001 -, possibilita que o poder público autorize, pela permissão de uso, a utilização de áreas de domínio da União, a título precário, para a realização de eventos de curta duração, de natureza recreativa, esportiva, cultural, religiosa ou educacional. 
Para Neves (2008), a permissão de uso é um "ato administrativo unilateral, discricionário e precário, gratuito ou oneroso, pelo qual a Administração Pública faculta a utilização privativa de bem público para fins de interesse público, sendo esse o traço distintivo da autorização".

A utilização do espaço público por meio de concurso público seria uma forma de permissão de uso, pelo qual a Administração Pública autorizaria um ente privado a usufruir do bem público, atendendo interesse público e que poderia ser gratuito ou oneroso para o solicitante, no caso, a banca organizadora.

O interesse público na realização do concurso público é destacado na própria Carta Magna de 1988, em seu art. 37, inc. II, in verbis:

Art. 37. A administração pública direta e indireta de qualquer dos Poderes da União, dos Estados, do Distrito Federal e dos Municípios obedecerá aos princípios de legalidade, impessoalidade, moralidade, publicidade e eficiência e, também, ao seguinte:

$[\ldots]$;

II - a investidura em cargo ou emprego público depende de aprovação prévia em concurso público de provas ou de provas e títulos, de acordo com a natureza e a complexidade do cargo ou emprego, na forma prevista em lei, ressalvadas as nomeações para cargo em comissão declarado em lei de livre nomeação e exoneração;

$[\ldots]$.

Logo, a obrigatoriedade da realização de concurso para a investidura em cargo ou emprego público torna necessário a contratação de uma banca organizadora/ examinadora para a realização da seleção, que, por sua vez, demanda de espaço físico para a realização do evento.

De fato, utilizar um espaço público para realização de concurso público reporta ao princípio da eficiência, que, segundo Alexandre de Moraes (2008, p. 326), 
dos critérios legais e morais necessários para a melhor utilização possível dos recursos públicos, de maneira a evitar-se desperdícios e garantir-se uma maior rentabilidade social.

Seguindo a mesma linha, Di Pietro (2006, p. 98) assevera que o princípio da eficiência

[...] apresenta, na realidade, dois aspectos: pode ser considerado em relação ao modo de atuação do agente público, do qual se espera o melhor desempenho possível de suas atribuições, para lograr os melhores resultados; e em relação ao modo de organizar, estruturar, disciplinar a Administração Pública, também como mesmo objetivo de alcançar os melhores resultados na prestação do serviço público.

É preciso recordar que a maioria das instituições de ensino público encontrase fechadas aos finais de semana, justamente o período que as bancas organizadoras costumam utilizar para a realização de seus eventos. Porém, no ordenamento jurídico, não há obrigatoriedade de utilização de espaço público para a realização de concurso público. Ou seja, algumas instituições públicas, desde que atendido os critérios mínimos para a realização do evento, poderiam estar arrecadando recursos, locando suas estruturas nos períodos ociosos e garantindo a melhor utilização dos recursos públicos.

Ainda sim, ofertar a possibilidade de uma instituição pública arrecadar recursos por meio de locação de espaço e vincular tais recursos ao investimento em infraestrutura, poderia contribuir com a qualidade do ensino, pois, segundo Passador, Yoshimoshi e Artoni (2011), "acredita-se que as escolas que possuem os piores desempenhos têm um conjunto maior de problemas diferenciando-se das demais escolas", uma vez que se tem aí a correlação da infraestrutura com a qualidade do ensino. 
Para tanto, seria necessário verificar se a locação do espaço público por

terceiros, por meio de permissão de uso, careceria ou não de licitação. Pois, a locação de espaço público ou privado por instituição pública tem dispensável o processo licitatório, desde que atendidas às necessidades da administração, como dispõe o art. 24, inc. X, da Lei n. 8.666/1993, in verbis:

Art. 24. É dispensável a licitação:

$[\ldots]$;

X - para a compra ou locação de imóvel destinado ao atendimento das finalidades precípuas da administração, cujas necessidades de instalação e localização condicionem a sua escolha, desde que o preço seja compatível com o valor de mercado, segundo avaliação prévia.

Nesse sentido, Neves (2008) destaca o entendimento do Controle Externo

Federal em relação à permissão do uso de bem público por terceiros:

Em relação à permissão de uso, a jurisprudência do Controle Externo Federal repercute 0 entendimento defendido pelo eminente Ministro Adhemar Ghisi (processo TC n. 625.182/1995-0 - Acórdão n. 29/2000-TCU$2^{\text {a }}$ Câmara), que, pelas características dessa modalidade, tem-na como excluída da exigência do art. $2^{\circ}$ do Estatuto de Licitações, mormente pelas definições ali contidas, especialmente a do seu parágrafo único que, ao definir contrato, estabelece: "Para os fins desta Lei, considera-se contrato todo e qualquer ajuste entre órgãos ou entidades da Administração Pública e particulares, em que haja um acordo de vontades para a formação de vínculo e a estipulação de obrigações recíprocas, seja qual for a denominação utilizada.

Com efeito, a permissão, concedida a título precário, não cria obrigações para a Administração Pública, que a concede e a retira, estritamente em razão de interesse público, e sem que haja necessidade de consentimento do permissionário. Nesses casos, como a permissão de uso não tem natureza contratual, preleciona a administrativista Maria Sylvia Zanella di Pietro (Temas Polêmicos sobre Licitações e Contratos, Malheiros Editores, $2^{\mathrm{a}}$ ed., 1995): "... não está abrangida pela Lei $n^{\circ} 8.666 / 93$, o que não impede a Administração de fazer licitação ou instituir outro processo de seleção, sempre recomendável quando se trata de assegurar igualdade de oportunidade a todos os eventuais interessados.

O Centro de Seleção e Promoção de Eventos (CESPE), por exemplo, como unidade gestora diretamente ligada um órgão público da administração indireta federal (a Fundação Universidade de Brasília - FUB), realiza suas contratações de 
espaço público ou privado, por meio das possibilidades de dispensa de licitação, nos termos do art. 24 da Lei n. 8.666/1993, hora com a justificativa embasada nos incs. I ou II (quando se tem a possibilidade de contratação direta devido ao valor está dentro dos limites da alínea "a", do inc. I e II, do art. 23, da referida Lei), hora justificando a contratação por meio do inc. X (quando a locação atende as finalidades precípuas da administração).

Art. 23. As modalidades de licitação a que se referem os incisos I a III do artigo anterior serão determinadas em função dos seguintes limites, tendo em vista o valor estimado da contratação:

I - para obras e serviços de engenharia:

a) convite - até $R \$ 150.000,00$ (cento e cinquenta mil reais);

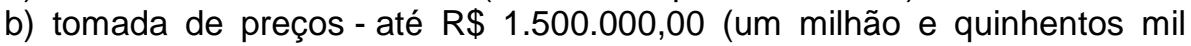
reais);

c) concorrência: acima de $\mathrm{R} \$ 1.500 .000,00$ (um milhão e quinhentos mil reais)

Art. 24. É dispensável a licitação:

I - para obras e serviços de engenharia de valor até $10 \%$ (dez por cento) do limite previsto na alínea "a", do inciso I do artigo anterior, desde que não se refiram a parcelas de uma mesma obra ou serviço ou ainda para obras e serviços da mesma natureza e no mesmo local que possam ser realizadas conjunta e concomitantemente; (Redação dada pela Lei n. 9.648, de 1998) II - para outros serviços e compras de valor até $10 \%$ (dez por cento) do limite previsto na alínea "a", do inciso II do artigo anterior e para alienações, nos casos previstos nesta Lei, desde que não se refiram a parcelas de um mesmo serviço, compra ou alienação de maior vulto que possa ser realizada de uma só vez; (Redação dada pela Lei n. 9.648, de 1998) [...].

X - para a compra ou locação de imóvel destinado ao atendimento das finalidades precípuas da administração, cujas necessidades de instalação e localização condicionem a sua escolha, desde que o preço seja compatível com o valor de mercado, segundo avaliação prévia; (Redação dada pela Lei n. 8.883, de 1994)

[...].

Conforme o exposto, uma instituição pública que queira locar ou ceder seu espaço por meio de permissão do uso estaria dispensada de realizar processo licitatório. Mas, quando ocorre interesse inverso, ou seja, quando é a Administração Pública que tem interesse em locar um espaço, seja ele público ou privado, o entendimento doutrinário é diferente. Neste sentido, a forma de contratação de espaço utilizada pelo Centro de Seleção e Promoção de Eventos/Centro Brasileiro 
de Pesquisa em Avaliação e Seleção e de Promoção de Eventos

(CESPE/CEBRASPE) (dispensa de licitação) não parece ser totalmente adequada.

É bem verdade que quando a Administração Pública pretende adquirir ou alugar imóvel para atender suas finalidades precípuas, ela pode dispensar a licitação e contratar diretamente com o locador, conforme dispõe o art. 24, inc. X, da Lei n. 8.666/1993. Porém, tal contratação não é totalmente livre. Para contratar diretamente exige-se que o imóvel a ser locado seja realmente indispensável para Administração Pública, em razão das necessidades de instalação e localização.

Logo, o CESPE/CEBRASPE, não poderia dispensar licitação nos termos do art. 24, inc. X, da Lei n. 8.666/1993, alegando que aquele imóvel é indispensável para execução de suas atividades, se o próprio centro não tem definido qual é o tipo de espaço que atende perfeitamente suas necessidades.

Isto posto, José dos Santos Carvalho Filho (2009, p. 249) assevera os seguintes ensinamentos sobre o artigo supramencionado:

Quando a Administração Pública pretende adquirir ou alugar imóvel destinado ao atendimento de suas finalidades precípuas, pode dispensar a licitação e contratar diretamente com o vendedor ou locador (art. 24, X).

Não é totalmente livre, entretanto esse tipo de ajuste. Exige o Estatuto que o imóvel a ser adquirido ou alugado seja realmente indispensável à Administração, em razão das necessidades de instalação e localização. A dispensa da licitação é razoável no caso: há situações em que, apesar de haver outras ofertas, apenas um imóvel atende realmente aos anseios administrativos. Assim, esse deve ser o imóvel adquirido ou alugado. Por outro lado, deve a Administração providenciar a avaliação prévia do imóvel, pois que não será legítimo o ajuste se o preço da compra ou do aluguel for incompatível com as condições normais de mercado.

A lei anterior não exigia a motivação da escolha nesse caso. O Estatuto vigente, no entanto, a impõe (art. 26), permitindo, em consequência, a verificação da legalidade do ajuste. A justificação expressa, desse modo, acarreta maior racionalidade no uso de imóveis e de recursos públicos, evitando inclusive, que tais contratos sejam celebrados mesmo quando existem outros imóveis públicos disponíveis. 
Tal corrente de pensamento é adotada pelo professor Jorge Ulisses Jacoby

Fernandes (2000, p. 388), que, inclusive, entende que a situação prevista no art. 24,

inc. X da Lei n. 8.666/1993, não configuraria caso de dispensa de licitação, mas, na

prática, hipótese de inexigibilidade, conforme se segue:

Trata-se, em verdade, de hipótese de inexigibilidade de licitação, visto que, uma vez existindo apenas um imóvel que satisfaça ao interesse da Administração, estará caracterizada a inviabilidade jurídica de competição. Nesse caso, se tão somente um imóvel é que atende às necessidades, não haverá licitação, tendo o legislador preferido colocar a hipótese entre os casos de dispensa, embora isto seja doutrinariamente condenável.

Marçal Justen Filho (2008, p. 308) também entende que, devido à inviabilidade de competição, a hipótese seria de inexigibilidade de licitação, e traz a seguinte lição:

A ausência de licitação deriva da impossibilidade de o interesse sob tutela estatal ser satisfeito através de outro imóvel, que não aquele selecionado. As características do imóvel (tais como localização, dimensão, edificação, destinação etc.) são relevantes, de modo que a Administração não tem outra escolha.

[...].

Antes de promover a contratação direta, a Administração deverá comprovar a impossibilidade de satisfação do interesse sob tutela estatal por outra via e apurar a inexistência de outro imóvel apto a atendê-lo.

Deverá verificar-se a compatibilidade do preço exigido com aquele de mercado. A Administração não poderá pagar preço ou aluguel superior ao praticado para imóveis similares.

A contratação depende, portanto, da evidenciação de três requisitos, a saber: a) necessidade de imóvel para desempenho das atividades administrativas; b) adequação de um determinado imóvel para satisfação das necessidades estatais; c) compatibilidade do preço (ou aluguel) com os parâmetros de mercado.

O Tribunal de Contas da União exigiu ao menos duas condições indispensáveis para realizar a dispensa de licitação para a aquisição ou locação de imóveis, nos seguintes termos:

'Para se promover a dispensa de licitação destinada à aquisição ou locação de imóvel, a norma impõe a observância de pelo menos duas condições essenciais, dentre outras: $1^{\mathrm{a}}$ ) necessidade de instalação e localização; e $2^{\mathrm{a}}$ ) avaliação prévia para se apurar a compatibilidade do preço com o valor de mercado. Essas condições devem ser aferidas de forma harmônica no contexto da lei de licitações, levando-se em consideração todos os princípios e preceitos, para evitar interpretações distorcidas.' (Decisão n. 343/1997, Plenário, rel. Min. Carlos Átila). 
Para que uma banca examinadora de concurso público, sendo esta, parte integrante da Administração Pública, como, por exemplo, o CESPE e a Escola de Administração Fazendária (ESAF), locasse sem licitação um espaço para realização de seus eventos, deveriam comprovar a inviabilidade de competição, seja pela localização do imóvel, seja pelas características mínimas necessárias no imóvel que atendam a demanda do evento.

O próprio Tribunal de Contas da União (TCU) entende da mesma forma que os doutrinadores supramencionados, bem como ressalta no Acórdão n. 1.512/2004, onde o administrador pode ser responsabilizado caso não observe os requisitos exigidos na Lei n. 8.666/1993:

$[\ldots]$.

4. Nesse sentido, o jurista Marçal Justen Filho, afirma que "a ausência de licitação deriva da impossibilidade de o interesse público ser satisfeito através de outro imóvel, que não aquele selecionado. As características do imóvel (tais como localização, dimensão, edificação, destinação etc.) são relevantes, de modo que a Administração não tem outra escolha. [...] Há hipóteses em que dois (ou mais) imóveis atendem aos reclamos da Administração. Ainda que os imóveis sejam infungíveis entre si, surgirão como intercambiáveis, tendo em vista a necessidade e o interesse da Administração Pública. Nesses supostos, a licitação se impõe. Estarão presentes os pressupostos da competição.".

5. No entender do eminente Conselheiro do TCDF Jorge Ulysses Jacoby Fernandes (in Contratação Direta sem Licitação, $5^{a}$ edição, Ed. Brasília Jurídica, pg 388), o art. 24, inciso X, da Lei 8.666/93, trata, na verdade, de "hipótese de inexigibilidade de licitação, visto que, uma vez existindo apenas um imóvel que satisfaça ao interesse da Administração, estará caracterizada a inviabilidade jurídica da competição [...] tendo o legislador preferido colocar a hipótese entre os casos de dispensa, embora seja doutrinariamente condenável.".

6. In casu, apesar de o imóvel locado ser destinado às "finalidades precípuas da Administração", as demais exigências do inciso X do art. 24 da Lei de Licitações não foram atendidas, quais sejam: a necessidade de instalação e localização condicionando a escolha e a avaliação prévia e compatibilidade de preços com os de mercado.

7. Quanto à primeira exigência, o responsável, em suas justificativas, consegue demonstrar a precariedade da então sede da autarquia e a premência de se promover a mudança de endereço da sede. No entanto, não comprova a inexistência de outro imóvel na área que pudesse satisfazer aos interesses da autarquia, pois as supostas consultas que teria feito à Secretaria de Patrimônio da União - SPU (segundo o responsável, o único imóvel disponível estaria onerado por encargos) e ao mercado, não foram devidamente atestadas nos autos. 
8. No tocante à avaliação prévia, registra-se que a contratação, pelo CADE, de cinco empresas para avaliarem os preços de mercado teria sido posterior à locação firmada, e não prévia, conforme exige a lei.

[...].

9. Assim, em consonância com a Unidade Técnica, entendo que deva ser aplicada multa individual de $\mathrm{R} \$ 5.000,00$ (cinco mil reais) ao [...] e de $\mathrm{R} \$$ $2.500,00$ (dois mil e quinhentos reais) à [...], concernentes à dispensa de licitação com inobservância dos requisitos impostos pelo inciso $X$ do art. 24 da Lei n. 8.666/93 (BRASIL, 2004).

Por consequência, tendo por base as características dos imóveis frequentemente locados pelo CESPE/CEBRASPE, é possível a realização de um confronto entre as instituições públicas e privadas, apresentando o espaço público disponível que atenda as necessidades de instalação e localização similares aos espaços privados contratados nos últimos anos. Assim, tem-se observado tanto o espaço público similar disponível, bem como os espaços privados que atendem as necessidades da banca, mas não são utilizados, o que excluiria a possibilidade de inexigibilidade de licitação pela comprovação da viabilidade de competição.

Sobre a questão da oferta dos bens públicos, Alonso (1999, p. 41) destaca:

A oferta dos bens públicos, por outro lado, é bem definida, pois, em princípio, é possível estimar o custo dos serviços públicos. Trata-se, portanto, de um mercado sem o lado da demanda. Conseqüentemente, não há sinalização de preços ao mercado. Isso não significa, entretanto, que não seja possível instituir mecanismos competitivos no provimento dos serviços públicos.

Diante do exposto, faz-se necessário que o CESPE/CEBRASPE defina as características do espaço físico a ser locado, pois, mesmo nas compras diretas, deve-se fazer a descrição do objeto da contratação. Assim, definindo o que se quer contratar, o ente poderá viabilizar a competição entre os interessados. Sobre tal questão, Justen Filho (2009, p. 133) esclarece que 
[...] como regra, toda e qualquer licitação exige que a Administração estabeleça, de modo preciso e satisfatório, as condições da disputa. Mais precisamente, a Administração tem de licitar aquilo que contratará - o que significa dominar, com tranquilidade, todas as condições pertinentes ao objeto a ser licitado [...].

E ainda, tem-se a Súmula n. 177 do TCU, que dispõe:

[...] a definição precisa e suficiente do objeto licitado constitui regra indispensável da competição, até mesmo como pressuposto do postulado de igualdade entre os licitantes, do qual é subsidiário o princípio da publicidade, que envolve o conhecimento, pelos concorrentes potenciais das condições básicas da licitação, constituindo, na hipótese particular da licitação para compra, a quantidade demandada uma das especificações mínimas e essenciais à definição do objeto do pregão.

Assim, qualquer órgão público, seja da administração direta ou indireta, ao realizar a compra de um bem ou a contratação de um serviço, deve descrever detalhadamente o objeto que satisfaz suas necessidades, sendo tal especificação indispensável na realização da despesa pública.

\subsection{Concurso público}

A utilização de concurso público para o provimento de cargos e funções públicas no Brasil teve início na Constituição Política do Império do Brasil, de 25 de março de 1824, outorgada pelo imperador D. Pedro I. Apesar da mesma não tratar especificamente sobre o tema "concurso público", o texto fez referência no seu Título VIII - que versa das disposições gerais e das garantias dos direitos civis e políticos dos cidadãos brasileiros - em seu art. 179 , inc. 14 , onde todo cidadão podia ser "admitido aos cargos públicos civis, políticos ou militares, sem outra diferença que não seja a de seus talentos e virtudes" (AGLANTZAKIS, 2003). 
Em seguida, a Constituição de 24 de fevereiro de 1891, também não previu em seus artigos nenhuma disposição acerca de concurso público. Porém, o seu art. 73, contribuiu do mesmo modo para a definição de critérios de acesso aos cargos públicos, in verbis:

Art 73 - Os cargos públicos civis ou militares são acessíveis a todos os brasileiros, observadas as condições de capacidade especial que a lei estatuir, sendo, porém, vedadas as acumulações remuneradas. $[\ldots]$

Além disso, trouxe em seu art. 79 a proibição de acumulação de cargos públicos entre Poderes distintos, bem como o acumulo dessas remunerações, in verbis: "Art 79 - O cidadão investido em funções de qualquer dos três Poderes federais não poderá exercer as de outro".

A partir 1934, identifica-se que a Constituição brasileira passa a dispor sobre a previsão da acessibilidade dos cargos públicos por meio de concurso público (AGLANTZAKIS, 2003). A previsão do art. 170, § $2^{\circ}$, de que "a primeira investidura nos postos de carreira das repartições administrativas, e nos demais que a lei determinar, efetuar-se-á depois de exame de sanidade e concurso de provas ou títulos", deu início a um novo modelo de ingresso no serviço público (AGLANTZAKIS, 2003).

Com o advento da Carta Magna de 1988 - aquela que mais trouxe inovações sobre o tema -, tornou-se obrigatória a prévia aprovação em concurso público para investidura em cargo ou emprego público, entretanto, com algumas exceções (AGLANTZAKIS, 2003). Tal obrigatoriedade está relacionada com um dos objetivos fundamentais estabelecidos na CF de 1988: a construção de uma sociedade livre, justa e solidária. Pois, uma das finalidades da seleção pública é minimizar as 
desigualdades entre os cidadãos brasileiros, oferecendo-Ihes as mesmas condições para exercerem seus direitos.

Assim, como consequência do princípio democrático e a construção de uma sociedade mais justa, a Carta Magna de 1988 ratificou a obrigatoriedade de concurso público, bem como suas exceções, em seu art. 37, inc. II, in verbis:

\begin{abstract}
Art. 37. A administração pública direta e indireta de qualquer dos Poderes da União, dos Estados, do Distrito Federal e dos Municípios obedecerá aos princípios de legalidade, impessoalidade, moralidade, publicidade e eficiência e, também, ao seguinte: (Redação dada pela Emenda Constitucional n. 19, de 1998)

$[\ldots]$;

II - A investidura em cargo ou emprego público depende de aprovação prévia em concurso público de provas ou de provas e títulos, de acordo com a natureza e a complexidade do cargo ou emprego, na forma prevista em lei, ressalvadas as nomeações para cargo em comissão declarado em lei de livre nomeação e exoneração (Redação dada pela Emenda Constitucional n. 19 , de 1998)

[...].
\end{abstract}

Neste sentido, o concurso público passou a ser a principal forma de ingresso no serviço público, com critérios de impessoalidade e isonomia, que minimizam as desigualdades e colocam em igualdade de condições todo cidadão, não importando para seleção fatores pessoais, tais como: sexo, idade, credo, aparência etc.

Talvez o concurso não seja a melhor forma de recrutar os melhores indivíduos para os cargos, mas, de fato, é a forma mais justa.

Em regra, a participação em concurso público está condicionada a idade mínima de 18 e máxima de 70 anos, podendo os editais estabelecerem idades diferentes. Ressalta-se que a Lei n. 8.112/1990, estabelece em seu art. $5^{\circ}$, apenas idade mínima para investidura de cargo público, in verbis:

Art.5ำ São requisitos básicos para investidura em cargo público:

I - a nacionalidade brasileira;

II - o gozo dos direitos políticos;

III - a quitação com as obrigações militares e eleitorais; 
IV - o nível de escolaridade exigido para o exercício do cargo;

$\checkmark$ - a idade mínima de dezoito anos;

No Governo Federal, os concursos públicos são previamente aprovados pelo Ministério do Planejamento, Orçamento e Gestão (MPOG) e devem seguir o disposto na Lei $\mathrm{n}$. 8.666/1993, tendo em vista que o concurso trata-se de uma modalidade de licitação, conforme apresenta o texto do art. 22, in verbis:

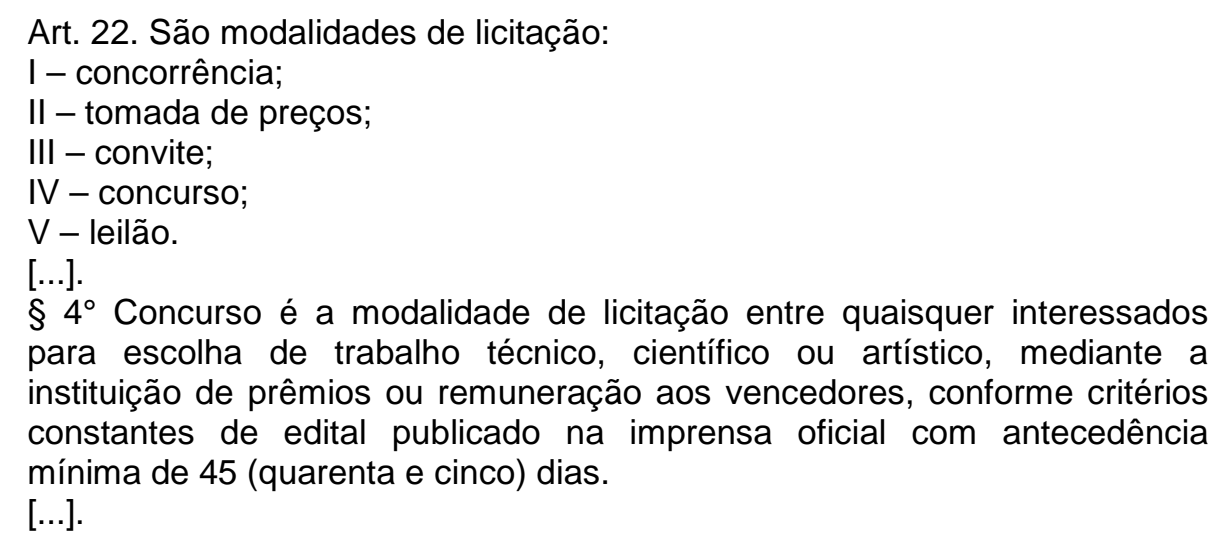

Apesar de a legislação vigente tratar da modalidade concurso, ainda resta normatizar muitos procedimentos desta, como, por exemplo, a forma de contratação de bancas organizadoras (feita por dispensa de licitação), valores de taxas de inscrição (não obrigatoriedade de o valor da taxa está associado ao valor do salário do respectivo cargo), locais para a realização dos certames (não estabelece critérios de utilização de espaço, nem prioriza a realização dos certames em espaço público), entre outros aspectos.

Contudo, devido às diversas dúvidas nessa modalidade de licitação, tramita no CN uma legislação específica para tratar de concurso público no país. Todavia, algumas UFs já se adiantaram e possuem norma especifica para concursos, como, por exemplo, o Distrito Federal, que recentemente publicou a Lei n. 4.949, de 15 de outubro de 2012, denominada "Lei dos Concursos". 
O surgimento de uma norma regulamentadora de concursos públicos no Distrito Federal é um avanço no processo seletivo público. Porém, nem todos os questionamentos foram solucionados com a publicação da legislação. Por exemplo, não houve a preocupação do legislador de estabelecer que os concursos públicos fossem realizados, prioritariamente, em espaços públicos, pois, obrigar a utilização destes nos certames poderia ser uma forma das instituições obterem receitas com a locação de seus espaços ou, pelo menos, a redução do escopo da contratação, o que acarretaria na economia de gasto público pelo órgão público contratante.

\subsection{Qualidade do gasto público}

Para Braga (2012), fazendo uso de um conceito contábil, o gasto

[...] se prende a ideia de um dispêndio financeiro que a organização arca para a obtenção de um produto ou benefício. Ou seja, trata-se do desembolso de recursos para o financiamento de uma aquisição ou contratação, o que no caso da adjetivação "gasto público".

O gasto público são os valores gastos pelo Estado para custear os serviços públicos prestados à sociedade. Assim, a contratação de pessoal para ingressar no serviço público e prestar serviço à sociedade passa pelo processo seletivo público, que podem demandar a contratação de bancas organizadoras e locação de imóveis para a realização dos eventos.

Para Pires (2008), o gasto é público não somente por visar o interesse público, mas também e, principalmente, por ser financiado com recursos públicos, auferidos compulsoriamente. Contudo, 
[...] é correto afirmar que existem diversos tipos de gastos públicos; somente um (o público-estatal), porém, retém a característica que impõe a exigência de que seja decidido por meio dos mecanismos da democracia representativa (orçamentação) e de que se submeta, para sua realização, ao processo licitatório (PIRES, 2008, p. 6).

A qualidade "é um conceito complexo, que em linhas gerais envolve algo de bom, algum produto ou serviço que atenda plenamente as necessidades do clientedestinatário" (BRAGA, 2012). Neste sentido, Braga (2012) destaca que "o gasto público de qualidade seria aquele que permitiria, com o menor desembolso, atender ao cidadão da melhor forma possível".

Já a qualidade dos serviços prestados na Administração Pública se dá pelos indivíduos que a compõem, que ingressam nela por meio de concurso público. Assim, tem-se "um consenso de que as organizações se constroem ou se destroem pelo desempenho das pessoas que nelas trabalham" (CARVALHO; TONET, 1994, p. 137); logo, a contratação de uma banca examinadora sem credibilidade, sem estrutura, que não possua itens básicos de segurança e sigilo da informação para a realização do evento, pode comprometer diretamente a qualidade do serviço público prestado ao cidadão.

Portanto, a qualidade do gasto público também está envolvida no concurso público, desde a contratação da banca examinadora até a realização do evento. Pois, a seleção pública envolve um grande volume de recursos públicos que devem ser gastos com transparência e responsabilidade.

Além disso, a licitação é obrigatória para a contratação deste tipo de serviço. Entretanto, a lei das licitações é apontada por especialistas como um dos principais fatores da perda de eficiência da gestão pública, devido a sua complexidade e as inúmeras possibilidades da má utilização dos recursos públicos. 
Os órgãos públicos que não possuem suas próprias bancas examinadoras, com estrutura, pessoal e competência necessária para realizar as seleções públicas da sua própria casa, em geral, realizam as contratações de outras bancas por meio de contratações diretas, sem licitação, alegando inviabilidade de competição para execução dos serviços.

Para a contratação de serviços dessa natureza, os órgãos públicos justificam a dispensa de licitação com base em duas exceções a regar, ora pelo art. 24, inc. XIII, ora pelo art. 25, inc. II da Lei n. 8.666/1993, in verbis:

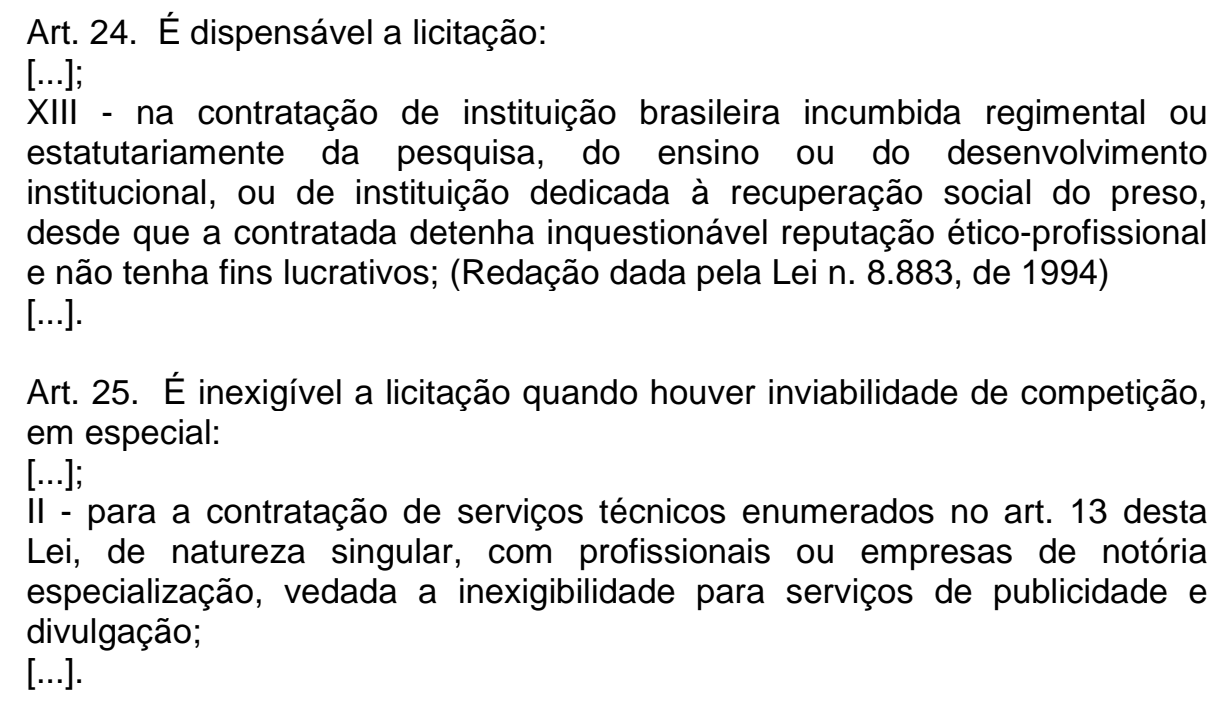

O TCU, em seu Acórdão n. 569/2005, ao interpretar o inc. XIII, do art. 24 da Lei n. 8.666/1993, faz algumas exigências quanto à instituição a ser contratada, conforme se segue:

[...] não suporta toda e qualquer contratação direta de instituição para a realização de concurso público, mas apenas de instituições que atendam os requisitos constantes do próprio texto legal, ou seja: ser brasileira, não ter fins lucrativos, apresentar inquestionável reputação ético-profissional, ter como objetivo estatutário-regimental a pesquisa, o ensino ou 0 desenvolvimento institucional.

Além disso, a instituição deve deter reputação ético-profissional na estrita área para a qual está sendo contratada (Decisão 908/1999 - Plenário-TCU) e o objeto contratado deve guardar correlação com o ensino, pesquisa ou o desenvolvimento institucional (BRASIL, 2005). 
Por outro lado, as bancas examinadoras, quando públicas, como, por exemplo, o CESPE/CEBRASPE, também fazem uso da contratação direta, por meio de dispensa de licitação, para locarem os espaços públicos e realizarem seus eventos. Assim, percebe-se que a exceção à regra de licitar virou rotina em ambas as partes, e contratante e contratado evitam licitar para fugir da complexidade da lei, adotando as exceções da legislação, pois, tanto para se contratar uma banca examinadora, como para locar o espaço, utiliza-se a contratação direta.

Para se ter uma ideia do gasto com a locação de espaço, de 2009 a 2014, o CESPE/CEBRASPE, de acordo com os dados apurados por meio do Sistema Integrado de Administração Financeira do Governo Federal (SIAFI), Categoria de Despesa: 3 (Despesas Correntes); Grupo de Despesa: 3 (Outras Despesas Correntes); Modalidade de Aplicação: 90 (Gastos Diversos do Governo Federal); Elemento de Despesa: 39 (Outros Serviços de Terceiros - PJ) e Subitem da Despesa: 10 (Locação de Imóveis), realizou 29.372 empenhos para a locação de espaço físico. Todas as locações foram feitas por meio de dispensa de licitação, com embasamento legal no art. 24, incs. I, II e X, da Lei n. 8.666/1993, in verbis:

Art. 24. É dispensável a licitação:

I - para obras e serviços de engenharia de valor até $10 \%$ (dez por cento) do limite previsto na alínea "a", do inciso I do artigo anterior, desde que não se refiram a parcelas de uma mesma obra ou serviço ou ainda para obras e serviços da mesma natureza e no mesmo local que possam ser realizadas conjunta e concomitantemente;

II - para outros serviços e compras de valor até $10 \%$ (dez por cento) do limite previsto na alínea "a", do inciso II do artigo anterior e para alienações, nos casos previstos nesta Lei, desde que não se refiram a parcelas de um mesmo serviço, compra ou alienação de maior vulto que possa ser realizada de uma só vez;

$[\ldots]$;

X - para a compra ou locação de imóvel destinado ao atendimento das finalidades precípuas da administração, cujas necessidades de instalação e localização condicionem a sua escolha, desde que o preço seja compatível com o valor de mercado, segundo avaliação prévia. 
Para o TCU, as contratações diretas são exceções à regra e não podem ser utilizadas de forma rotineira pela instituição pública, pois caracteriza falta de planejamento e pode acarretar em fracionamento da despesa, conforme dispõe em nas decisões que se seguem:

Adote o sistemático planejamento de suas compras, evitando o desnecessário fracionamento na aquisição de produtos de uma mesma natureza e possibilitando a utilização da correta modalidade de licitação, nos termos do art. 15, § $7^{\circ}$, II, da Lei n. 8.666/93 (BRASIL, 2000).

Atente para o fato de que, atingindo o limite legalmente fixado para dispensa de licitação, as demais contratações para serviços da mesma natureza deverão observar a obrigatoriedade da realização de certame licitatório, evitando a ocorrência de fracionamento de despesa (BRASIL, 2003).

Abstenha-se de fracionar despesas relativas ao mesmo objeto, quando o somatório das parcelas indique modalidade de licitação diferente da adotada, conforme disposições contidas nos arts. $23, \S \S 1^{\circ}, 2^{\circ}$ e $5^{\circ}$, e 24 , inciso II, parte final, da Lei $\mathrm{n}^{\circ} 8.666 / 93$, segundo orientação desta Corte de Contas constante nas Decisões ns 241/94, 202/96, 449/96 e 484/96, todas do Plenário, dentre outras (BRASIL, 2005).

No mesmo sentido é a doutrina de Carvalho Filho (2009, p. 250-251), onde, ao comentar o dispositivo, sustenta que:

\begin{abstract}
A ausência de licitação deriva da impossibilidade de o interesse público ser satisfeito através de outro imóvel, que não aquele selecionado [...]. A aquisição ou locação de imóvel destinado a utilização específica ou em localização determinada acarreta a inviabilidade de competição. Trata-se de hipótese de inexigibilidade de licitação e o caso sujeita-se ao disposto no art. 25.

Há hipóteses em que dois (ou mais) imóveis atendem aos reclamos da Administração. Ainda que os imóveis sejam infungíveis entre si, surgirão como intercambiáveis tendo em vista a necessidade e o interesse da Administração Pública. Qualquer dos imóveis satisfará a exigência que justifica a aquisição pela Administração. Nesses supostos, a questão muda de figura e a licitação se impõe. Estarão presentes os pressupostos de competição.
\end{abstract}

O entendimento do TCU admite que a possibilidade de contratação direta de banca organizadora de concurso desde que tal ação se enquadre perfeitamente nas hipóteses previstas na Lei Geral de Licitações e Contratos (Lei n. 8.666/1993); pois, 
este é o entendimento no voto condutor do Acórdão TCU n. 569/2005.

Isto posto, os órgãos de controle ainda alertam quanto ao fracionamento da despesa, com justificativa das compras diretas em razão do valor, pois, é reputada ilegal. Neste sentido, a Revista de Licitações e Contratos do TCU (2010, p. 104) atenta que 0

Fracionamento, a luz da Lei de Licitações, caracteriza-se quando se divide a despesa para utilizar modalidade de licitação inferior a recomendada pela legislação para o total da despesa ou para efetuar contratação direta". Logo, o fracionamento da despesa é tratado como crime nos termos do art. 89 da Lei 8.666/93:

Dispensar ou inexigir licitação fora das hipóteses previstas em lei, ou deixar de observar as formalidades pertinentes à dispensa ou à inexigibilidade:

Pena - detenção, de 3 (três) a 5 (cinco) anos, e multa.

Parágrafo único. $\mathrm{Na}$ mesma pena incorre aquele que, tendo comprovadamente concorrido para a consumação da ilegalidade, beneficiou-se da dispensa ou inexigibilidade ilegal, para celebrar contrato com o Poder Público.

A própria CF de 1988, em seu art. 37, inc. XXI, estabelece que a administração direta e indireta de qualquer dos Poderes da União, dos Estados, do Distrito Federal e dos Municípios, devem realizar licitação para posterior contratação de obras, serviços, compras e alienações, ressalvados os casos especificados na legislação.

Portanto, a licitação é regra tanto para a contratação de uma banca examinadora, como para a locação de um espaço físico, quando esta for uma instituição pública. Pois, optar por não fazer a licitação é um risco assumido pela Administração Pública, uma vez que o intuito do referido procedimento administrativo é selecionar a proposta mais vantajosa para a celebração de contrato, assegurando a igualdade entre os participantes do certame.

Todavia, nem sempre a licitação garantirá a eficiência do gasto e os resultados mais vantajosos para a Administração Pública. Neste sentido, para Motta (2010, p. 116): 


\begin{abstract}
Apesar da pressuposição de que todos os princípios citados na lei, ou pertencentes ao direito administrativo brasileiro, devem ser rigorosamente aplicados às licitações, em casos concretos, quando há dúvidas ou problemas de interpretação, transparece uma hierarquia que estabelece alguns princípios como mais importantes que outros. Os da Legalidade e da Isonomia, por exemplo, prevalecem com larga margem sobre princípios como o da Razoabilidade ou da Eficiência138. Não tendo sido treinados para refletirem em termos de eficiência do gasto público e conscientes dos riscos do não cumprimento estrito dos ritos, os servidores públicos naturalmente priorizam a Legalidade e a Isonomia, em detrimento de quaisquer outros princípios.
\end{abstract}

Logo, salienta-se que não é o processo licitatório que garantirá a qualidade do gasto público, mas é uma ferramenta que foi criada com o objetivo de melhorar a eficiência no uso racional dos recursos públicos.

É complexo avaliar a necessidade de processo licitatório para a contratação de banca examinadora para a realização de seleções públicas, pois, o órgão público tem o interesse naquela banca que possa prestar os serviços com a maior competência possível, com bom relacionamento ao candidato, transparência do certame, bem como a segurança adequada do conteúdo das provas.

A contratação direta de banca examinadora, por meio de inexigibilidade de licitação, em muitos casos, desconsidera completamente o princípio da economicidade, pois, a arrecadação dos valores referente às inscrições dos candidatos não chega nem próximo ao que se gasta na contratação dos serviços. Neste caso, não há um equilíbrio no que se arrecada e o que se gasta e, consequentemente, não qualidade no gasto público.

Do mesmo modo, a instituição pública contratada para a realização da seleção pública não pode, de qualquer forma, locar imóveis sem atender aos critérios e hipóteses previstas em Lei. Pois, aí também haveria o comprometimento da eficiência do gasto público. Tal situação é observada justamente quando não há o aproveitamento dos espaços públicos para a realização de concursos públicos, 
pois, se existem espaços públicos disponíveis, por que eles não são utilizados em sua totalidade nas seleções?

Assim, focar nas especificidades das compras públicas, nas etapas da contratação e o no processo do gasto do dinheiro público, também são formas de abordar a qualidade do gasto público, uma vez que os custos instruídos no processo de compras podem influenciar na concreta implementação desta.

Para Braga (2012), a qualidade do gasto está em destaque nos congressos e discussões, bem como nos artigos científicos, pois é apontada como um dos caminhos a ser seguidos na solução dos problemas da maquina estatal.

Diante do quadro, identificar as justificativas de uma instituição pública na locação de um espaço privado para a realização de um concurso público, enquanto que uma instituição privada utilizada o espaço público ao invés do privado para realização de evento similar, é uma forma de se estudar a qualidade do gasto público na execução de despesas com a locação de espaço físico.

Tais situações fazem refletir sobre a questão do gasto público e do gasto privado, pois, por qual motivo a instituição privada fez uso do espaço público e a instituição pública locou um espaço privado? Para Pires (2008, p. 6), reside aí a principal diferença entre o gasto público e gasto privado: "No caso deste último, o indivíduo o realiza somente se sentir-se interessado no resultado, poupando o recurso disponível caso não deseje certo bem ou serviço".

De fato, o estudo sobre a qualidade do gasto não se restringe aos economistas acadêmicos,

[...] mas passou a integrar o discurso do Banco Mundial e do próprio Fundo Monetário Internacional (FMI). Estes organismos internacionais vêm enfatizando a qualidade do gasto público, e não simplesmente o corte do gasto público. Ambos têm se empenhado em introduzir o tema "qualidade 
do gasto público" na agenda de reforma do Estado de diversos países, entre eles o Brasil (ALONSO, 1999, p. 37).

A qualidade do gasto está correlacionada com a gestão dos custos. Logo, quando uma instituição pública loca um determinado espaço para a realização de um evento, ela deve preocupar-se com uma pesquisa de mercado que comprove que o local contratado atenda as necessidades da instituição e possua um preço justo, compatível com o preço médio do mercado. Portanto, a contratação direta, principalmente quando utilizado os argumentos da inexigibilidade (art. 25, Lei n. 8.666/1993), caracterizado pela inviabilidade de competição, correm risco de aumento dos custos, pois não há demonstrativo para se comparar o preço de mercado.

Por fim, destaca-se que:

A melhoria substancial no desempenho de uma organização governamental, por sua vez, requer sistemas de informações gerenciais que deem sustentação aos seus processos decisórios. Em particular, tais sistemas devem contemplar medidas de resultados e o custo para obtê-los (ALONSO, 1999, p. 43).

Sendo o gasto público um instrumento de atuação do governo, aperfeiçoar a forma de contratação buscando sempre a obtenção do preço melhor preço ou aquele mais justo ou vantajoso para a Administração Pública, atentando-se para o custo-benefício da contratação, contribui para que o dinheiro público seja gasto com qualidade, influenciando em resultados positivos na economicidade dos recursos públicos, bem como na melhoria dos serviços prestados à sociedade. 


\section{ESTRATÉGIA DA PESQUISA}

O presente capítulo descreve o percurso metodológico utilizado na pesquisa. Neste sentido, a apresentação que se segue buscou descrever os procedimentos adotados, a descrição dos dados coletados e as técnicas de análise dos dados logrados na pesquisa.

\subsection{Percurso metodológico}

Para que os resultados fossem alcançados, empregaram-se diversas fontes de pesquisa. De modo específico, foram analisadas as despesas com locação de espaço físico nos processos de contratação do Centro de Seleção e Promoção de Eventos/Centro Brasileiro de Pesquisa em Avaliação e Seleção e de Promoção de Eventos (CESPE/CEBRASPE) como organizador do concurso público. Contudo, além da análise contratual, verificaram-se os dados de arrecadação, empenho e pagamentos realizados por aquela Banca Examinadora de 2009 à 2014, por meio do Portal da Transparência e do Sistema Integrado de Administração Financeira do Governo Federal (SIAFI).

A análise processual para a verificação dos contratos, empenhos e pagamentos foi garantida pela Lei n. 12.527/2011, denominada de Lei de Acesso a Informação (LAI), sendo o CESPE, conforme dispõe o art. 8 do referido ditame, obrigado a promover, independentemente de requerimentos, a divulgação em local de fácil acesso, no âmbito de suas competências, de informações de interesse coletivo ou geral por eles produzidas ou custodiadas. 
Quanto aos meios, a pesquisa foi de cunho bibliográfico, de campo e documental; de cunho bibliográfico porque se realizou pesquisas em sites (redes eletrônicas), jornais, revistas especializadas em locação de espaço público, licitações e contratos públicos e áreas afins, legislação, artigos científicos, além de publicações e jurisprudência dos Tribunais e órgãos de controle (vide Quadro 1, a seguir). Pois, conforme Cervo, Bervian e Silva (2007, p. 60), a pesquisa bibliográfica procura explicar um determinado problema a partir de referências teóricas publicadas.

Quadro 1 - Natureza bibliográfica dos textos utilizados na pesquisa.

\begin{tabular}{|c|c|}
\hline Natureza dos textos & Denominação da natureza dos textos \\
\hline Sites & $\begin{array}{l}\text { Administradores; Âmbito Jurídico; Concursos no Brasil; Maxpress; } \\
\text { Portal de Contabilidade; Revista Digital de Direito Administrativo; } \\
\text { Revista dos Tribunais; Revista Espaço Acadêmico; Revista Exame; } \\
\text { Revista Jus Navigandi; Secom UnB; Wikipédia. }\end{array}$ \\
\hline Jornais e Revistas & $\begin{array}{l}\text { Boletim de Licitações e Contratos; Cad. Saúde Públ.; Caderno de } \\
\text { Pesquisas em Administração; Didática; Educar; Em Tese; } \\
\text { Observatorium: Revista Eletrônica de Geografia; Public } \\
\text { Administration; REICE - Revista Electrónica Iberoamericana sobre } \\
\text { Calidad, Eficacia y Cambio en Educación; RESR; Revista Brasileira } \\
\text { de Educação Especial; Revista Brasileira de Estudos de População; } \\
\text { Revista de Administração Pública; Revista Digital de Direito } \\
\text { Administrativo; Revista do Serviço Público; Revista Licitações e } \\
\text { Contratos - Orientações e Jurisprudência do TCU. }\end{array}$ \\
\hline Órgãos Públicos & $\begin{array}{l}\text { Controladoria-Geral da União (CGU); Governo do Distrito Federal } \\
\text { (GDF); Instituto Brasileiro de Geografia e Estatística (IBGE); Instituto } \\
\text { Nacional de Estudos e Pesquisas Educacionais Anísio Teixeira } \\
\text { (INEP); Ministério da Educação (MEC); Ministério da Fazenda (MF); } \\
\text { Ministério do Planejamento, Orçamento e Gestão (MPOG); Palácio } \\
\text { do Planalto; Secretaria de Estado de Educação do Distrito Federal } \\
\text { (SEDF); Tribunal de Contas da União (TCU); Universidade de } \\
\text { Brasília (UnB). }\end{array}$ \\
\hline
\end{tabular}

Fonte: Dos autores.

Para Vergara (2005, p. 46), a investigação documental caracteriza-se quando "é realizada em documentos conservados no interior de órgãos públicos e privados de qualquer natureza, ou com pessoas, registros, anais, regulamentos, circulares, ofícios, memorandos e outros". Assim, a investigação foi também de cunho 
documental, porque se valeu de documentos internos do CESPE/CEBRASPE, por meio de anuários estatísticos disponibilizados por aquela Banca Examinadora e análise processual das contratações.

Por fim, executou-se uma investigação de campo, porque tem-se aqui uma "investigação empírica realizada no local onde ocorreu um fenômeno ou que dispõe de elementos para explicá-lo" (VERGARA, 2005, p. 45), haja vista que foram coletados dados primários nas dependências do CESPE/CEBRASPE. Ainda sim, foram efetuadas 10 (dez) visitas às instituições de ensino no Distrito Federal, para avaliar a capacidade real destacada pelo Instituto Nacional de Estudos e Pesquisas Educacionais Anísio Teixeira (INEP) e a qualidade da infraestrutura.

Quanto aos fins, devido às poucas informações e o pouco conhecimento acumulado e sistematizado do problema, efetuou-se uma investigação exploratória e descritiva; exploratória porque embora os concursos públicos tenham sido tema de diversas pesquisas, não se verificou estudos que abordem a locação de espaço público para a realização de concurso. De acordo com Money et al. (2005), a pesquisa exploratória é necessária quando as questões de pesquisa possuem lacunas ou quando há pouco conhecimento científico para nortear as hipóteses. Segundo Vergara (2005, p. 45), "a investigação exploratória é realizada em área na qual há pouco conhecimento acumulado e sistematizado. Por sua natureza de sondagem, não comporta hipóteses que, todavia, poderão surgir durante ou ao final da pesquisa".

A pesquisa também foi descritiva porque descreveu percepções, expectativas e sugestões para utilização do espaço público em concurso. Para Vergara (2005, p. 45), a pesquisa descritiva "não tem compromisso de explicar os fenômenos que descreve, embora sirva de base para tal explicação". 


\subsection{Técnica de coleta de dados}

Em um primeiro momento foram analisados os dados apurados por meio de documentos e fontes de dados de arquivos. Money et al. (2005) indica que, para estudos exploratórios sejam coletados dados em pequenas amostras ou estudos de casos por meio de entrevistas pessoais, grupos focais e observação, uma vez que possibilitam identificar e clarificar os problemas de pesquisa. Já para os estudos de natureza descritiva é necessária maior quantidade de dados, colhidos por meio de surveys ou bancos de dados disponíveis.

Assim, os dados coletados foram dos últimos 06 (seis) anos de atividades exercidas pelo CESPE/CEBRASPE, especificamente os exercícios de 2009, 2010, 2011, 2012, 2013 e 2014. A coleta se deu principalmente naquela Banca Examinadora, por meio de consulta telefônica, visita a sítios eletrônicos (vide Quadro 1), obtenção e análise de relatórios específicos, mapas e figuras, análise processual das contratações.

Para complementar e aprofundar a discussão do problema de pesquisa, foram realizadas 03 (três) entrevistas, sendo que a primeira de forma aberta e as outras 02 (duas) de forma semiestruturadas com 04 (quatro) representantes da instituição envolvidos na fase de seleção e contratação dos espaços privados utilizados na realização dos concursos públicos. De acordo com Bleger (1980), Triviños (1987), Manzini (1990; 1991) e Dias e Omote (1995), existem vantagens, desvantagens e cuidados necessários quando da utilização da entrevista como procedimento para coleta de dados em pesquisa. Neste sentido, o roteiro (vide Quadro 2, a seguir) foi construído a partir das orientações dos objetivos específicos. 
Quadro 2 - Perguntas para entrevista no CESPE/CEBRASPE.

\begin{tabular}{|c|c|}
\hline Questão & Pergunta \\
\hline 1. & $\begin{array}{l}\text { O CESPE utiliza algum critério para selecionar/contratar um espaço para realização de } \\
\text { concurso público? }\end{array}$ \\
\hline 2. & $\begin{array}{l}\text { Quais características básicas/mínimas para que o CESPE defina a contratação/locação } \\
\text { de espaço físico para realização de concurso? }\end{array}$ \\
\hline 3. & $\begin{array}{l}\text { O CESPE possui lista/cadastro das instituições públicas e privadas que possam ser } \\
\text { utilizadas em concurso público? }\end{array}$ \\
\hline 4. & $\begin{array}{l}\text { O CESPE possui dados de espaço físico (capacidade de oferta por aluno) das } \\
\text { instituições públicas e privadas que são utilizadas em concurso público? }\end{array}$ \\
\hline 5. & $\begin{array}{l}\text { Quais as principais instituições públicas e privadas são contratadas pelo CESPE para } \\
\text { realização de concurso público? }\end{array}$ \\
\hline 6. & $\begin{array}{l}\text { Qual modalidade de contratação o CESPE utiliza para locação de espaço para } \\
\text { realização dos seus eventos? }\end{array}$ \\
\hline 7. & $\begin{array}{l}\text { O espaço público, quando utilizado pelo CESPE para realização de concurso público, é } \\
\text { contratado da mesma forma que o espaço privado? }\end{array}$ \\
\hline 8. & $\begin{array}{l}\text { Como é feito o pagamento para as instituições públicas que cedem/locam seus espaços } \\
\text { para realização de concurso público? Recebem recursos financeiros? }\end{array}$ \\
\hline 9. & $\begin{array}{l}\text { O CESPE possui lista das instituições públicas e privadas do DF, com dados de espaço } \\
\text { disponível, localização e capacidade por aluno? }\end{array}$ \\
\hline 10. & $\begin{array}{l}\text { Qual critério o CESPE utiliza para definir o preço do candidato por espaço locado? (ex: } \\
\text { Instituição A cabe } 500 \text { candidatos e a Instituição B cabe } 800 \text { candidatos. Para } \\
\text { instituição A será pago } R \$ 1,80 \text { por candidato e para Instituição B } R \$ 1,90 \text {. Qual critério } \\
\text { utilizado para esta definição de valores? Localização? Infraestrutura? Tamanho do } \\
\text { Espaço?) }\end{array}$ \\
\hline 11. & O CESPE possui anuário estatístico? Pode ser disponibilizado para consulta? \\
\hline 12. & $\begin{array}{l}\text { Solicitação de dados estatísticos: } \\
\text { - Informar quantidade de concursos realizados pelo CESPE de } 2000 \text { a 2014, por } \\
\text { Estado, contendo quantidade de inscritos por concurso (destacando quantidade de } \\
\text { inscritos por Estado), valor da contratação, data, e quantidade de } \\
\text { estabelecimentos/instituições utilizadas (com os respectivos nomes e CNPJ). } \\
\text { - Quantidade de concursos realizado no DF no período de } 2000 \text { à 2014. Destacando as } \\
\text { instituições contratadas para realização do evento, o valor da contratação, custo por } \\
\text { candidato, e a quantidade de inscritos por concurso. }\end{array}$ \\
\hline
\end{tabular}

Fonte: Dos autores.

Segundo Gil (2010), as entrevistas devem ser em número suficiente para que todos os atores relevantes possam se manifestar, podendo envolver múltiplas unidades ou departamentos. Para aquele autor, nas entrevistas devem ser selecionados os indivíduos que estejam articulados com o grupo ou a organização, pois nem sempre os dirigentes máximos são os melhores informantes. Neste sentido, a pesquisa realizou entrevistas em setores diferentes, com indivíduos de 
níveis hierárquicos distintos, buscando informações desde a direção àqueles diretamente envolvidos com a execução dos serviços.

Inicialmente fez-se um levantamento anual da despesa com locação de espaço físico feito pelo CESPE nos últimos 06 (seis) anos (2009 a 2014) para a obtenção do volume de recurso gasto com este tipo de despesa. Tal consulta se deu sítio do Portal da Transparência - que disponibiliza os gastos do Governo Federal por Unidades Gestoras e por natureza de despesa, porém, sem tantos detalhes - e no SIAFI - fazendo uso de programas de gerenciamentos, como, por exemplo, o SIAFI GERENCIAL e o CONSIAFI (Solução Gerencial para consultas ao SIAFI).

Após o levantamento da despesa total com a locação de espaço físico, fez-se necessário filtrar as instituições que foram contratadas, para que fosse possível a análise do quantitativo de instituições públicas e privadas contratadas no Distrito Federal, bem como qual a frequência da contratação das mesmas.

Fez-se uso ainda de técnicas de pesquisas contábeis (auditoria e perícia) para selecionar, entre tantas outras, apenas as despesas com locação de espaço físico realizadas pelo CESPE/CEBRASPE, inscrito como Unidade Gestora n. 154079, no período de 2009/2014, detalhando a despesa da seguinte forma: Categoria de Despesa: 3 (Despesas Correntes); Grupo de Despesa: 3 (Outras Despesas Correntes); Modalidade de Aplicação: 90 (Gastos Diversos do Governo Federal); Elemento de Despesa: 39 (Outros Serviços de Terceiros - Pessoa Jurídica - PJ) e Subitem da Despesa: 10 (Locação de Imóveis).

De modo complementar também fez-se uso da auditoria geral, com vistas a avaliar a confiabilidade dos valores apurados das receitas e despesas por meio do Portal da Transparência e os publicados no Relatório de Gestão da Universidade de Brasília (UnB), em confronto com os dados retirados diretamente do SIAFI e 
CONSIAFI. Sobre tal questão, Franco (2009, p. 207) atenta que este tipo de auditoria caracteriza-se como parcial ou específica.

Por meio da referida consulta, foi possível identificar as instituições públicas e privadas que foram utilizadas/locadas pelo CESPE/CEBRASPE nos exercícios de 2009 a 2014. Porém, não havia a possibilidade de detalhar a despesa por Estado ou Município, nem identificar se o contratado era público ou privado. Logo, mesmo com a informação do detalhamento da despesa com locação de imóveis, fez-se necessário a realização de outras consultas para identificar a localidade do gasto, bem como a natureza do contratado.

O relatório de toda despesa de locação de imóveis do CESPE/CEBRASPE no período supramencionado apresentou mais de 68 mil lançamentos contábeis, entre Nota de Sistema (NS), Nota de Empenho (NE) e Ordem Bancária (OB), com uma média de cerca de 11.400 lançamentos contábeis anuais, vinculados à quase 04 (quatro) mil credores diferentes.

Assim, foram realizadas consultas no site da Receita Federal (vide Anexo "C"), para a verificação dos dados cadastrais de cada credor, por meio das informações do Cadastro Nacional de Pessoa Jurídica (CNPJ) na Receita Federal do Brasil.

Por meio do CNPJ é possível identificar dados importantes do contratado, tais como: o Município, o Estado e a Natureza Jurídica. Assim, foi possível separar apenas os imóveis locados no Distrito Federal - foco da pesquisa, bem como definir as instituições públicas e privadas.

Vale destacar que, apesar das despesas estarem disponíveis no portal da transparência, as consultas pelo CONSIAFI foram realizadas com autorização por escrito tanto do CESPE/CEBRASPE quanto pela Diretoria de Contabilidade e 
Finanças (DCF) da UnB (responsável pela contabilidade da Fundação Universidade de Brasília - FUB), que tinha o CESPE como uma unidade descentralizada. Pois, em 21 de outubro de 2014, foi encaminhado o primeiro documento para acesso às informações de despesas realizadas pelo CESPE. Inclusive, por solicitação da Direção do CESPE/CEBRASPE, a DCF também elaborou relatórios das despesas com locação de espaço, o que contribuiu para que o pesquisador pudesse confrontar os relatórios cedidos pela DCF e os já elaborados pelo mesmo, ofertando maior fidedignidade aos valores apurados.

Por conseguinte, foi possível observar que na locação de espaço físico para a realização de concurso pelo CESPE/CEBRASPE, as instituições privadas eram maioria; logo, se fazia necessário solicitar mais detalhes da contratação. Neste sentido, foi encaminhado um documento no dia 23 de março de 2015, solicitando, com fundamento na Lei n. 12.527/2011 (LAI), as seguintes informações:

1) Informações se há repasse de recursos quando o CESPE, para realização dos seus eventos, loca/utiliza o espaço físico de qualquer parte de sua estrutura da FUB. Se não há repasse de recursos ou pagamento, qual a justificativa.

2) Indicar lista de instituições públicas e privadas, do Distrito Federal, utilizadas pelo CESPE para realização de eventos. Informar se há um critério ou características mínimas estabelecidas pelo CESPE para utilização do espaço físico.

3) Indicar nome e contato dos servidores/funcionários responsáveis pela contratação/seleção do espaço físico para realização dos eventos.

4) Informar quantidade de concursos realizados pelo CESPE de 2005 à 2015, por Estado, contendo quantidade de inscritos, órgão/empresa contratante, valor da contratação, data, e quantidade de estabelecimentos/instituições utilizadas.

5) Informar se o CESPE possui anuário estatístico, se sim, se o mesmo poder ser disponibilizado para consulta ou se pode ser enviado pelo email informado acima, desde sua primeira versão.

6) Informar quais os critérios e características utilizados pelo CESPE para definir a contratação/ locação de espaço físico para a realização de concurso público.

7) Disponibilizar organograma do CESPE e CEBRASPE com os nomes e contatos dos respectivos responsáveis por cada setor. 
Em 16 de junho de 2015, o CESPE/CEBRASPE entrou em contato por meio de um servidor ligado ao setor contábil, agendando uma reunião para entender sobre o interesse da solicitação encaminhada àquele Centro. Nesta mesma data deu-se uma reunião com este mesmo servidor, nas dependências daquela Banca Examinadora, com duração de cerca de 45 minutos - tempo necessário para esclarecer sobre a necessidade das informações e que se tratava de um trabalho acadêmico.

As entrevistas foram essenciais para coletar os dados que não foram possíveis por meio de pesquisa bibliográfica e de observação. A entrevista é definida por Haguette (1997, p. 86) "como um processo de interação social entre duas pessoas na qual uma delas, o entrevistador, tem por objetivo a obtenção de informações por parte do outro, o entrevistado".

Inicialmente, as entrevistas foram realizadas de forma aberta, atendendo a finalidade exploratória e que, conforme o desenvolvimento, foram alteradas posteriormente para atender os objetivos propostos.

Para Boni e Quaresma (2005), na entrevista aberta, as perguntas são respondidas dentro de uma conversação informal. Neste sentido, foi utilizada para obter o maior número de informações sobre o tema, segundo a visão dos entrevistados.

As entrevistas exploratórias, conforme Quivy e Campenhoudt (2003, p. 69), "devem ajudar a constituir a problemática de investigação". Neste sentido, a referida técnica de coleta, além de alargar o campo de investigação, contribuiu para a descoberta dos aspectos básicos da contratação. 
$\mathrm{Na}$ entrevista exploratória foi possível entender o processo de reestruturação vivenciado pelo CESPE, com o encerramento de suas atividades e a transformação em uma OS sem fins lucrativos: o CEBRASPE. Logo, o servidor alertou que a equipe do CESPE encontrava-se reduzida e que por este motivo havia uma sobrecarga de trabalho, o que impedia de repassar as informações no prazo estabelecido na LAI, que seria de até 20 dias corridos.

Passado mais de 30 dias sem obter as informações solicitadas, foi encaminhado novamente o documento ao CESPE. Em seguida, houve contato do Centro, por e-mail, agendando uma nova reunião no dia 23 de julho de 2015 com o Diretor daquela Banca Examinadora.

$\mathrm{Na}$ data agendada estiveram presentes o Diretor e um servidor do CESPE. O diretor novamente informou das dificuldades do fornecimento das informações devido ao reduzido número de servidores que ali se encontravam disponíveis, pois, a maioria dos servidores já estava compondo a equipe do CEBRASPE. Contudo, também houve questionamentos de que algumas informações solicitadas, como, por exemplo, "os critérios e características utilizados pelo CESPE para definir a contratação/locação de espaço físico para a realização de concurso público". Neste sentido, o Diretor alegou que tal informação fazia parte do ramo de atividade realizado pelo CESPE e que demandaria uma autorização também do diretor do CEBRASPE.

Após a indicação de servidores para entrevistas, deu-se a entrevista estruturada, ou formalizada, desenvolvida a partir de uma relação fixa de perguntas, cuja ordem e redação permaneceram invariáveis para todos os entrevistados (GIL, 1999), conforme apresentado no Quadro 2. Sobre tal questão, Boni e Quaresma (2005, p. 73) entendem que "as entrevistas estruturadas são elaboradas mediante 
questionário totalmente estruturado, ou seja, é aquela onde as perguntas são previamente formuladas e tem se o cuidado de não fugir a elas".

Assim, conforme previsto no projeto de pesquisa, foram programadas entrevistas com os representantes do CESPE/CEBRASPE com o objetivo da obtenção de respostas sobre a forma de seleção e contratação das instituições que são utilizadas para realização dos concursos públicos. As entrevistas foram realizadas na forma presencial com cerca de 40 minutos de duração cada.

Ainda em relação à entrevista, esta foi direcionada para a obtenção de informações diretamente com os responsáveis nas áreas de contratações e logísticas, conforme apresenta o Quadro 3, a seguir, e com mais detalhes no Apêndice "A". Ressalta-se que a mesma foi anotada para facilitar a análise, sendo focalizada e por pautas, tendo em vista que o assunto já estava pré-determinado e que havia uma sequência de vários pontos do assunto a serem explorados.

Quadro 3 - Lista de entrevistados.

\begin{tabular}{|l|l|}
\hline \multicolumn{2}{|c|}{ Seleção de Entrevistado } \\
\hline \multicolumn{1}{|c|}{ Função } & Período \\
\hline Diretor CESPE & $2013-2016$ \\
\hline Gestor Financeiro & $2012-2016$ \\
\hline Coordenador de Logística de Eventos & $2012-2016$ \\
\hline Gerente de Logística & $2014-2016$ \\
\hline
\end{tabular}

Fonte: Dos autores.

Por fim, no dia 14 de janeiro de 2016, por meio da Carta CEBRASPE n. 06/2016, o CESPE/CEBRASPE formalizou resposta de todas as perguntas apresentadas anteriormente no Quadro 2, inclusive, disponibilizando um Compact Disc (CD) com dados estatísticos dos concursos realizados no período 2010-2015. 


\subsection{Técnica de análise dos Dados}

O tratamento especializado dos dados se deu de modo qualitativo, por meio de análise documental e de conteúdo, fazendo uso de métodos estatísticos descritivos, e por meio de análise descritiva das informações, para a apresentação dos dados de forma estruturada.

Faz-se importante salientar que, apesar da pesquisa apresentar percentuais e medidas de tendência central, quando calculado, por exemplo, média de receitas, de gastos, da demanda por concurso, entre outras, tais dados não qualificam o estudo como uma análise quantitativa, haja vista que as medidas em questão se deram para ofertar suporte a pesquisa qualitativa.

Segundo Bauer e Gaskel (2002 apud AUGUSTO et al., 2013, p. 749),"muitos esforços foram despendidos na tentativa de justapor pesquisa quantitativa e qualitativa como paradigmas competitivos." Conforme Vidich e Lyman (2006, p. 40 apud AUGUTSO et al., 2013, p. 749), “[...] todos os métodos de pesquisa são, no fundo, qualitativos [...]; o emprego de dados quantitativos ou de procedimentos matemáticos não elimina o elemento intersubjetivo que representa a base da pesquisa social".

De acordo com Oliveira (2001, p. 75), o emprego de recursos e técnicas estatísticas desde a mais simples, como os percentuais, desvio padrão e as meditas de tendência central (média, moda e mediana), caracterizaria o método quantitativo.

Sobre a questão da análise do material qualitativo, Minayo e Sanches (1993, p. 246) destacam que existe, vários métodos e técnicas de análise do material qualitativo e assim, a estatística quando usada de forma superficial e pobre, não poder ser atribuída ao método, ou seja, não caracteriza um método quantitativo, 
pois, segundo os autores, um verdadeiro método qualitativo descreve, compreende e explica, trabalhando exatamente nesta ordem.

Assim, no presente estudo adotou-se o entendimento de que medidas de tendência, mesmo aquelas mais simples como citadas por Oliveira (2001), não torna a analise da pesquisa em quantitativa e qualitativa, pois as medidas utilizadas apenas complementam a descrição dos dados apurados.

Demo (2013) explica que na pesquisa qualitativa são considerados, por exemplo, a pesquisa ação, a história oral, os levantamentos feitos com questionários abertos ou diretamente gravados, a análise de grupo, entre outros aspectos. Para aquele autor, "definem-se como metodologias alternativas, porque buscam salvaguardar o que a metodologia dura joga fora, por não caber no método, sendo por vezes o mais importante na realizada" (DEMO, 2013, p. 152).

Demo (2013) ainda assevera que, em geral, os pesquisadores fogem de questionários abertos, pois, quando feitos, é de praxe formalizá-los ou codificá-los, formando o conteúdo em categorias. Porém, para superar parte do problema de meras respostas e meras perguntas, que podem estar facilmente desfocadas em sentido hermenêutico, o questionário aberto ou fechado é certamente preferível.

Conforme Neves (1996, p. 3), "em uma pesquisa, seja qualitativa ou quantitativa, o pesquisador não se ocupa simplesmente de acumular dados; coletados considerando que seu significado seja útil para os fins da pesquisa e dentro de um dado contexto".

Foi utilizado o método da estatística descritiva com o objetivo de descrever, analisar e interpretar os dados numéricos da amostra selecionada, com base em tabelas, gráficos e resumos numéricos (FONSECA; MARTINS, 1996, p. 101). 
Segundo Silvestre (2007), a estatística descritiva é constituída pelo conjunto de métodos destinados à organização e descrição dos dados através de indicadores sintéticos ou sumários, que consiste, portanto, no recolhimento, na apresentação, análise e interpretação de dados numéricos através da criação de instrumentos adequados, quais sejam: quadros, gráficos e indicadores numéricos.

A análise descritiva, também chamada de análise exploratória de dados, consiste em técnicas básicas e simplificadas para explorar ao máximo um conjunto de dados (tabelas, gráficos, medidas, escalas de mensuração, tipos de variáveis). Há a descrição e dedução de dados, mas não a indução - a extrapolação para dados reais da população.

Para a obtenção de maior familiaridade junto ao problema de pesquisa, fizeram-se entrevistas com pessoas que estiveram envolvidas com as práticas do problema pesquisado. Sobre tal questão, Duarte (2004, p. 215) atenta que as entrevistas

[...] são fundamentais quando se precisa/deseja mapear práticas, crenças, valores e sistemas classificatórios de universos sociais específicos, mais ou menos bem delimitados, em que os conflitos e contradições não estejam claramente explicitados.

Diante do exposto, a presente pesquisa teve por intenção descrever as situações que envolvem desde a arrecadação dos últimos anos do CESPE/CEBRASPE às despesas com alocação de espaço físico e suas características. Por isso, a técnica utilizada para o tratamento dos dados foi a estatística descritiva.

Para atingir os objetivos do presente estudo, por meio do Quadro 4, a seguir, tem-se o modelo de análise de pesquisa que norteia todas as etapas da pesquisa a partir do problema apresentado. 
Quadro 4 - Modelo analítico de pesquisa (continua).

\begin{tabular}{|c|c|c|c|c|c|}
\hline \multicolumn{6}{|c|}{ Pesquisa } \\
\hline Objetivos específicos & $\begin{array}{l}\text { a) Descrever os critérios } \\
\text { e características } \\
\text { utilizados pelo CESPE } \\
\text { para definir a } \\
\text { contratação/locação de } \\
\text { espaço privado para a } \\
\text { realização de concurso } \\
\text { público no período de } \\
2009 \text { a } 2014 \text {. }\end{array}$ & $\begin{array}{l}\text { b) Identificar as instituições } \\
\text { públicas e privadas do } \\
\text { Distrito Federal utilizadas } \\
\text { pelo CESPE para } \\
\text { realização de concurso } \\
\text { público e comparar os } \\
\text { gastos com a locação de } \\
\text { espaço físico para } \\
\text { realização desses eventos, } \\
\text { entre esses entes no } \\
\text { período de } 2009 \text { a } 2014 \text {. }\end{array}$ & $\begin{array}{l}\text { c) Demonstrar a evolução } \\
\text { dos recursos captados } \\
\text { pelo CESPE e os gastos } \\
\text { com locação de espaço } \\
\text { físico para realização de } \\
\text { concurso público no } \\
\text { período de } 2009 \text { a } 2014 \text {. }\end{array}$ & $\begin{array}{l}\text { d) Descrever as } \\
\text { instituições públicas de } \\
\text { ensino com os critérios e } \\
\text { características utilizadas } \\
\text { pelo CESPE para definir } \\
\text { a contratação/locação de } \\
\text { espaço para concurso } \\
\text { público no Distrito } \\
\text { Federal. }\end{array}$ & $\begin{array}{l}\text { e) Apresentar a forma de } \\
\text { contratação, a } \\
\text { modalidade de licitação e } \\
\text { as justificativas do } \\
\text { CESPE para locação de } \\
\text { espaço físico para } \\
\text { realização de concurso } \\
\text { público no período de } \\
2009 \text { a } 2014 \text {. }\end{array}$ \\
\hline Referencial teórico & $\begin{array}{l}\text { Locação de espaço } \\
\text { público /Concurso } \\
\text { público/ Conceito de } \\
\text { publico e privado. }\end{array}$ & $\begin{array}{l}\text { Locação de espaço } \\
\text { público/Conceito de } \\
\text { publico e privado/Concurso } \\
\text { público/Qualidade do } \\
\text { gasto. }\end{array}$ & Qualidade do gasto. & $\begin{array}{l}\text { Locação de espaço } \\
\text { público/Conceito de } \\
\text { público e privado. }\end{array}$ & $\begin{array}{l}\text { Locação de espaço } \\
\text { público /Concurso } \\
\text { público/ }\end{array}$ \\
\hline
\end{tabular}


Quadro 4 - Modelo analítico de pesquisa (conclusão).

\begin{tabular}{|c|c|c|c|c|c|}
\hline \multicolumn{6}{|c|}{ Operacionalização da Pesquisa } \\
\hline Métodos & Qualitativo & Qualitativo & Qualitativo & Qualitativo & Qualitativo \\
\hline Autores & $\begin{array}{l}\text { MONEY et al. (2005); } \\
\text { BONI \& QUARESMA } \\
\text { (2005); HAGUETTE } \\
\text { (1997); FONSECA \& } \\
\text { MARTINS(1996). }\end{array}$ & $\begin{array}{l}\text { MONEY et al. (2005); } \\
\text { BONI \& QUARESMA } \\
\text { (2005); HAGUETTE } \\
\text { (1997); FONSECA \& } \\
\text { MARTINS(1996). }\end{array}$ & $\begin{array}{l}\text { MONEY et al. (2005); } \\
\text { BONI \& QUARESMA } \\
\text { (2005); HAGUETTE } \\
\text { (1997); FONSECA \& } \\
\text { MARTINS(1996). }\end{array}$ & $\begin{array}{l}\text { MONEY et al. (2005); } \\
\text { BONI \& QUARESMA } \\
\text { (2005); HAGUETTE } \\
\text { (1997); FONSECA \& } \\
\text { MARTINS(1996). }\end{array}$ & $\begin{array}{l}\text { MONEY et al. (2005); } \\
\text { BONI \& QUARESMA } \\
\text { (2005); HAGUETTE } \\
\text { (1997); FONSECA \& } \\
\text { MARTINS(1996). }\end{array}$ \\
\hline $\begin{array}{l}\text { Técnica de coleta de } \\
\text { dados }\end{array}$ & $\begin{array}{l}\text { Dados } \\
\text { primários/Documental/En } \\
\text { trevista }\end{array}$ & $\begin{array}{l}\text { Dados primários e } \\
\text { secundários/Documental/E } \\
\text { ntrevista. }\end{array}$ & $\begin{array}{l}\text { Dados secundários/Fontes } \\
\text { de dados de arquivos. }\end{array}$ & $\begin{array}{l}\text { Dados } \\
\text { secundários/Fontes de } \\
\text { dados de arquivos. }\end{array}$ & $\begin{array}{l}\text { Dados } \\
\text { secundários/Observação } \\
\text { participante/Inspeção- } \\
\text { visitação. }\end{array}$ \\
\hline $\begin{array}{l}\text { Técnica de análise de } \\
\text { dados }\end{array}$ & $\begin{array}{l}\text { Análise do conteúdo do } \\
\text { material coletado nos } \\
\text { documentos e } \\
\text { entrevistas. }\end{array}$ & $\begin{array}{l}\text { Análise do conteúdo do } \\
\text { material coletado nos } \\
\text { documentos e entrevistas. }\end{array}$ & Estatística descritiva. & Estatística descritiva. & $\begin{array}{l}\text { Amostragem/Estatística } \\
\text { descritiva. }\end{array}$ \\
\hline
\end{tabular}

Fonte: Dos autores, 2016. 


\subsection{Limitações do método}

No desenvolvimento da pesquisa, apresentaram-se dificuldades referentes à coleta de dados, uma vez que a análise processual das contratações de espaço físico dependeram de autorização do representante máximo da instituição organizadora dos concursos, no caso, o CESPE/CEBRASPE. Mesmo vigorando a Lei n. 12.527/2011 (LAI), normalmente essas consultas são dificultosas, pois se tratam de contratações públicas que envolvem responsabilidade de agentes públicos, os quais estão constantemente recebendo recomendações pelos órgãos de controle, devido à identificação de falhas na instrução processual ou pela falta de atendimento à legislação vigente.

Além disso, aparentemente, após as primeiras reuniões, a pesquisa foi vista pelos gerentes da instituição como uma forma de fiscalização da instrução processual, na qual poderia acarretar em descoberta de erros ou que prejudicasse o ramo do negócio do CESPE/CEBRASPE, assim como justificado em respostas por meio de e-mail, o que acabou por dificultar ainda mais a obtenção dos dados desejados.

Ademais, algumas das informações solicitadas na entrevista semiestruturada, como, por exemplo, àquelas referentes ao item 12 do questionário, não foram respondidas, pois, apesar de já haver autorização do Diretor do CESPE, o coordenador alegou que tais informações precisariam de autorização da Direção do CESBRASPE. Em resumo, a situação de autorização de ambos os diretores sempre foi uma barreira para a conclusão do presente estudo, o que demandou um longo tempo na aquisição das respostas. 
Ao passo que, outras informações como, por exemplo, àquelas pertinentes aos itens 5 e 10, a princípio, não foram respondidas com a justificativa de que estas não eram públicas e faziam parte do negócio de trabalho do CESPE/CEBRASPE, e que sua publicidade poderia atrapalhar a competitividade da organização, bem como a assinatura de futuros contratos.

Outro fator limitador da pesquisa foi que, mesmo o CESPE/CERASPE formalizando as informações, não ficou claro sobre qual a característica do espaço mínimo a ser locado pelo CESPE/CEBRASPE, ou seja, para se comparar com o espaço público disponível no Distrito Federal, era necessário que o Centro informasse exatamente qual o número mínimo de salas, se há necessidade de ar condicionado, quantidade mínima de aluno por sala etc., pois sem a referida informação, não haveria uma referência para confrontar os espaços.

Além disso, a informação sobre a forma de uso de instituições públicas sem ônus para o CESPE/CEBRASPE também se mostrou uma questão sem uma resposta precisa, pois não houve uma resposta sobre como é feito a compensação às instituições públicas que disponibilizam seus espaços e não recebem recursos financeiros.

Salientam-se também as dificuldades encontradas para o acesso às dependências das escolas de ensino básico (Médio e Fundamental), pois, mesmo os estabelecimentos sendo públicos, por diversas vezes, o pesquisador foi impedido de tirar fotos das salas das instituições.

Quando da autorização para o acesso às dependências das instituições públicas, desde a primeira solicitação à resposta final, passaram-se mais de 13 meses, com documentos enviados aos diretores, aos coordenadores regionais e à Secretaria de Estado de Educação do Distrito Federal (SEDF), e que, mesmo após 
autorização da visita as dependências, não foi autorizada a divulgação dos nomes e das localidades das escolas (vide Apêndice "B").

Ademais, o Distrito Federal talvez não fosse a Unidade da Federação (UF) mais adequada para se realizar a presente pesquisa, haja vista que durante a pesquisa foi observado (vide Gráfico 1, a seguir) que o Distrito Federal, em comparação com outras Unidades, possui a terceira pior disponibilidade de espaço público no País.

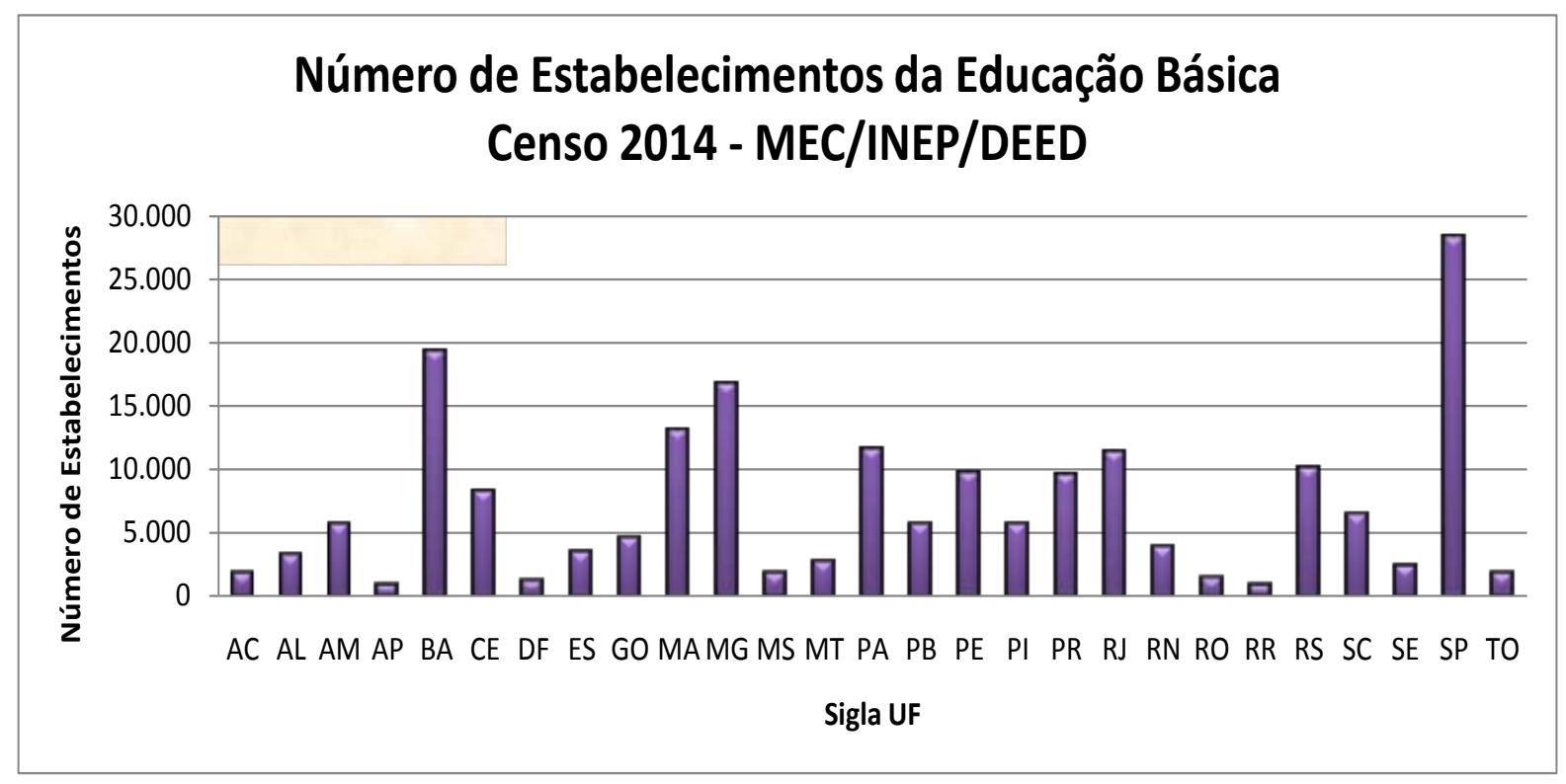

Gráfico 1 - Disponibilidade de espaço público por Unidade da Federação.

Fonte: INEP (2014).

Assim, das 188 mil instituições de ensino básico da rede pública e privada no País, as UFs que possuem menor quantidade de estabelecimentos são: Roraima (787), Amapá (843) e Distrito Federal (1.128). Por outro lado, Minas Gerais (16.704), Bahia (19.137) e São Paulo (28.220) são aquelas que possuem maior número de estabelecimentos, conforme exposto no Quadro 5, a seguir. 
Quadro 5 - Número de estabelecimentos da Educação Básica por Unidade da Federação.

\begin{tabular}{|c|c|}
\hline Unidade da Federação & Quantidade de Estabelecimentos \\
\hline $\mathrm{RR}$ & 787 \\
\hline AP & 843 \\
\hline DF & 1.128 \\
\hline RO & 1.336 \\
\hline$A C$ & 1.672 \\
\hline MS & 1.674 \\
\hline TO & 1.689 \\
\hline SE & 2.267 \\
\hline MT & 2.688 \\
\hline $\mathrm{AL}$ & 3.220 \\
\hline ES & 3.298 \\
\hline $\mathrm{RN}$ & 3.744 \\
\hline GO & 4.552 \\
\hline AM & 5.524 \\
\hline $\mathrm{PI}$ & 5.536 \\
\hline PB & 5.602 \\
\hline SC & 6.245 \\
\hline CE & 8.196 \\
\hline PR & 9.390 \\
\hline $\mathrm{PE}$ & 9.631 \\
\hline RS & 10.046 \\
\hline RJ & 11.210 \\
\hline PA & 11.437 \\
\hline MA & 12.877 \\
\hline MG & 16.704 \\
\hline BA & 19.137 \\
\hline SP & 28.220 \\
\hline Total & 188.673 \\
\hline
\end{tabular}

Fonte: INEP (2014). 
Destarte, se a presente pesquisa se desse fazendo uso da UF São Paulo, o espaço público poderia comportar bem mais a demanda do CESPE/CEBRASPE na locação de espaço para a realização de concurso, haja vista que São Paulo é o Estado que mais possui instituições públicas. 


\section{RESULTADOS}

O objetivo geral do trabalho foi analisar se as instituições de ensino público no Distrito Federal podem substituir o espaço privado utilizado pelo CESPE/CEBRASPE na realização de concurso público. Desta forma, apresentam-se os seguintes resultados na pesquisa a partir da proposta do objetivo geral.

\subsection{Considerações iniciais}

Durante a elaboração do presente estudo, com a análise dos espaços públicos do Distrito Federal, foram surgindo outras dúvidas, sendo necessário a realização de uma nova reunião com a equipe do CEBRASPE, que teve como objetivo principal complementar as informações da solicitação anterior, principalmente em relação às características mínimas exigidas pelo CESPE/CEBRASPE para a contratação de espaço público.

Assim, no dia 26 de janeiro de 2016, fez-se outra reunião para tratar dos pontos pendentes. O CESPE/CEBRASPE informou que, apesar de não ter um modelo padrão de estrutura mínima para locação, para o Distrito Federal poderiam ser utilizadas as características da menor instituição locada para a realização do maior evento já realizado, ou seja, aquele que teve maior quantidade de inscritos, pois, este tipo de evento (o Exame Nacional do Ensino Médio - ENEM) demandaria a locação máxima de espaço possível.

Em 28 de janeiro de 2016, o CESPE/CEBRASPE disponibilizou uma planilha com dados das instituições utilizadas no maior evento de 2015: o ENEM. A referida 
seleção pública teve cerca de 03 (três) milhões e setecentos mil inscritos, sendo que somente no Distrito Federal, o número de inscritos ultrapassou a marca dos 162 mil candidatos.

Para a realização deste evento, foram utilizadas somente no Distrito Federal, 215 instituições públicas e privadas. Assim, considerado pelo CESPE/CEBRASPE um evento de grande porte, o Centro entende que a estrutura mínima que pode ser locada é a menor instituição utilizada em uma seleção pública como esta.

Destarte, identificadas as menores instituições locadas, é possível estabelecer a menor estrutura possível apta a ceder o espaço para locação. E com base neste tipo de instituição, foi possível realizar um confronto com o espaço público disponível no Distrito Federal, com características similares ou melhores do que aquele, identificando, assim, quantas instituições de ensino no Distrito Federal poderiam ser utilizadas pelo CESPE/CEBRASPE.

Complementarmente, para a identificação e possibilidade de comparação da similaridade das instituições de ensino públicas e privadas, foram utilizados dados do Censo Escolar 2014 (INEP, 2014), com informações fornecidas pela Secretaria de Estado de Educação do Distrito Federal (SEDF), pelo Ministério da Educação e pelo Instituto Nacional de Estudos e Pesquisas Educacionais Anísio Teixeira (INEP), que contribuíram com a análise dos espaços disponíveis no Distrito Federal.

A partir dos dados apurados nas entrevistas exploratórias, foi possível confrontar alguns destes com aqueles cedidos pelos órgãos de educação, como, por exemplo, a disponibilizada pelo INEP, referente ao quantitativo, por estabelecimento, de salas disponíveis no Distrito Federal.

Porém, algumas informações do Censo Escolar, conforme já havia alertado o coordenador de logística do CESPE/CEBRASPE, não condizem com a realidade do 
estabelecimento, porque, por exemplo, uma escola com 20 salas, não necessariamente possui 20 salas ativas (ou utilizáveis) para o recebimento de alunos, o que não atenderia o interesse da pesquisa de apresentar o real espaço disponível para que aquelas pudessem ser utilizadas em seleções públicas.

Isto posto, para que chegássemos ao espaço real disponível, foram realizadas 10 inspeções/visitações em instituições públicas, a fim de verificar se o espaço físico informado no Censo Escolar condizia com a realidade. Logo, observou-se que a quantidade de salas informadas no Censo não poderiam ser aceitas, em sua totalidade, como espaço disponível, principalmente quando a necessidade de locação seria a realização de concursos públicos, uma vez que algumas dessas salas eram ocupadas pela administração (Ex: sala de coordenação, secretaria, almoxarifado), laboratórios, refeitórios, entre outras atividades. Ou seja, não havia carteiras e nem a possibilidade de colocar alunos, nem tampouco candidatos para a realização de concursos.

Diante do exposto, consideraram-se as salas que não estavam aptas a receberem alunos como inativas, sendo excluídas da disponibilidade do espaço, para que fosse encontrada a capacidade real de cada instituição pública.

Por outro lado, o Censo das Escolas do Governo do Distrito Federal (GDF) (2014) trouxe a informação da quantidade de turmas e alunos matriculados, ou seja, esta seria a capacidade real da instituição. Pois, para cada turma, exige-se uma respectiva sala e, pelo número total de matriculados, foi possível obter a capacidade total de alunos naquela instituição e, consequentemente, a média de alunos por sala. Por exemplo, o Censo Escolar do GDF traz a escola 53001265 - CEF CASEB, localizada no Plano Piloto/Cruzeiro, como uma escola que possui 19 salas permanentes. Porém, uma dessas salas foi ocupada pela Coordenação da escola, 
ou seja, esta se tornou uma sala de apoio. Logo, apenas 18 salas poderiam ser utilizadas, como é possível observar no detalhamento de salas existentes e utilizadas na Tabela 1, a seguir.

Tabela 1 - Detalhamento de quantidade de salas por estabelecimento.

CRE: Plano Piloto-Cruzeiro

53001265 - CEF CASEB Localização: Urbana

\begin{tabular}{|c|c|c|c|c|c|}
\hline \multicolumn{3}{|c|}{ Salas Existentes } & \multicolumn{3}{|c|}{ Salas Utilizadas } \\
\hline \multicolumn{2}{|c|}{ Salas de Aula } & \multirow{2}{*}{$\begin{array}{c}\text { Salas de } \\
\text { RecursolApoio }\end{array}$} & \multicolumn{2}{|c|}{ Salas de Aula } & \multirow{2}{*}{$\begin{array}{c}\text { Salas de } \\
\text { RecursolApoio }\end{array}$} \\
\hline Permanentes & Provisórias & & No prédio & $\begin{array}{c}\text { Fora do } \\
\text { prédio }\end{array}$ & \\
\hline 19 & - & 1 & 19 & - & 1 \\
\hline
\end{tabular}

Fonte: Censo Escolar (2014).

Por conseguinte, para ratificar a informação da disponibilidade do espaço físico, buscou-se observar o detalhamento de cada estabelecimento com a quantidade de alunos matriculados, distribuídos por série e turno, conforme apresentado na Tabela 2, a seguir. 
Tabela 2 - Detalhamento de quantidade de turmas e matrícula por estabelecimento.

\begin{tabular}{|c|c|c|c|c|c|c|c|c|c|c|c|}
\hline \multirow[t]{2}{*}{ Descrição } & \multicolumn{2}{|c|}{ Matutino } & \multicolumn{2}{|c|}{ Vespertino } & \multicolumn{2}{|c|}{ Noturno } & \multicolumn{2}{|c|}{ Integral } & \multicolumn{2}{|c|}{ Total } & \multirow[t]{2}{*}{ Média M/T } \\
\hline & Turma & Matrícula & Turma & Matrícula & Turma & Matrícula & Turma & Matrícula & Turma & Matrícula & \\
\hline $6^{\circ} \mathrm{Ano} / 5^{\mathrm{a}}$. série & 4 & 74 & 1 & 90 & - & - & - & - & 5 & 164 & 32,80 \\
\hline $7^{\circ} \mathrm{Ano} / 6^{\mathrm{a}}$. série & 4 & 95 & 2 & 82 & - & - & - & - & 6 & 177 & 29,50 \\
\hline $9^{\circ} \mathrm{Ano} / 8^{\mathrm{a}}$. série & 5 & 136 & 5 & 107 & - & - & - & - & 10 & 243 & 24,30 \\
\hline $\begin{array}{l}\text { Correção da } \\
\text { Distorção }\end{array}$ & - & - & 6 & - & - & - & - & - & 6 & & 0,00 \\
\hline Total (Finais) & 18 & 447 & 17 & 356 & - & - & - & - & 35 & 803 & 22,94 \\
\hline
\end{tabular}

Fonte: Censo Escolar (2014). 
Faz-se importante destacar que entre todos os turnos de funcionamento da escola, foi selecionado o maior quantitativo de turmas e alunos entre eles. Por exemplo, observou-se que no turno matutino e uma escola, tem-se 18 turmas com 447 alunos matriculados e, no turno vespertino, 17 turmas e 356 alunos matriculados. Logo, foi possível identificar que aquela escola possui, no mínimo, 18 salas ativas (pois possui 18 turmas), com capacidade média de, pelo menos, 24 alunos por sala. Portanto, os dados consolidados trouxeram um dos dados mais relevantes da pesquisa: a oferta real, por estabelecimento, do espaço público disponível no Distrito Federal.

Ainda em relação à capacidade total das escolas do Distrito Federal, foi considerado a superlotação das escolas, conforme divulgado pela SEDF, por meio do Relatório Sintético de Inscrições no Telematrícula - 2015, sendo apresentado o número de vagas disponíveis e número de contemplados às vagas do ensino público no Distrito Federal. O resultado do confronto vaga versus contemplado foi de que mais de 5.200 alunos, principalmente na educação infantil, não conseguiram uma vaga no ensino público do Distrito Federal em 2015.

Para aproximar-se ainda mais da oferta de espaço público no Distrito Federal que tivesse características similares, aqueles espaços privados contratados pelo CESPE/CEBRASPE para a realização de concurso foram excluídos - de imediato, as instituições que apenas atendiam ao ensino infantil, haja vista que suas estruturas (como, por exemplo, carteira, bebedouro, banheiros etc.) não atendem a demanda de um adulto. Além dessas, também foram excluídas as instituições públicas que estavam localizadas em áreas rurais, pois, a localização e logística foram apresentados pelo CESPE/CEBRASPE como relevantes na locação do espaço, mesmo que este tivesse características básicas similares aos espaços 
anteriormente contratados. Ademais, a realização de um evento em uma escola localizada em área rural poderia comprometer o fácil acesso ao candidato, que é devidamente assegurado nas cláusulas editalícias, bem como apresentar um aumento no percentual de ausentes no certame.

Isto posto, foi possível comparar se determinada escola atenderia ou não as características mínimas exigidas pelo CESPE/CEBRASPE no quesito espaço total disponível e capacidade total por sala de aula. Assim, foram excluídas todas as instituições que não atendiam as características básicas/mínimas em relação ao espaço físico.

Para entender o processo de contratação do espaço físico utilizado pelo CESPE/CEBRASPE para a realização de concurso, foi solicitado àquele Centro o acesso a alguns processos que já tiveram suas fases encerradas. A seleção destes fez-se por meio de amostragem, para constatar se nos autos do processo havia a denominação das características do espaço contratado e se, estes, apresentavam as características mínimas previamente estabelecidas por aquele centro.

Para a analise processual das contratações foi realizado uma seleção de amostras não probabilísticas intencionais, escolhendo casos para a amostra que representem o "bom julgamento" da população/universo e amostras probabilísticas, do tipo casuais simples, onde cada elemento da população tem oportunidade igual de ser incluído na amostra (KAUARK; MANHÃES; MEDEIROS, 2010).

Apurado a oferta de espaço público do Distrito Federal, passou-se a análise da demanda do CESPE/CEBRASPE por espaço físico. Tal informação foi calculada com base no número de inscritos por concursos. Esses dados foram fornecidos pelo CESPE/CEBRASPE, por meio de relatório, e confrontados com os previamente 
coletados no site oficial do Centro de Seleção, haja vista a obrigatoriedade de divulgação de demanda candidato por vaga.

Diante do exposto, a presente pesquisa trouxe as 02 (duas) informações necessárias para apresentar as conclusões, quais sejam: a demanda do CESPE/CEBRASPE pela locação de espaço para a realização de seus eventos e a oferta de espaço público do Distrito Federal. Assim, foi possível analisar se, de acordo com os critérios de locação estabelecidos pelo CESPE/CEBRASPE, tem-se a viabilidade/alternatividade de se utilizar o espaço público ao invés do privado para a realização dos concursos públicos organizados por aquele Centro.

\subsection{Descrição dos critérios e características utilizados pelo CESPE/CEBRASPE para definir a contrataçãollocação de espaço privado para a realização de concurso público no período 2009-2014}

Mediante a entrevista e os dados cedidos pelo CESPE/CEBRASPE por meio da Carta CEBRASPE n. 06/2016, identificou-se que os critérios para locação do espaço são basicamente definidos pela infraestrutura, localização e capacidade por instituição.

Apesar de que o CESPE/CEBRASPE possuir um cadastro com todas as instituições públicas e privadas do DF, bem como as informações necessárias para locação do espaço, este centro não possui um check list (ou documento similar de conferência/controle) próprio para identificar as características mínimas da instituição que poderão ser utilizada, nem tão pouco possui um modelo exato de estabelecimento que poderá ser locado. 
Porém, o CESPE/CEBRASPE possuindo cadastro prévio dessas instituições, pode seleciona-los de acordo com a demanda do concurso, contudo, neste caso, havendo características similares de espaços disponíveis, não haveria a possibilidade de contratação direta, ou seja, haveria necessidade de abertura de processo licitatório.

A entrevista informal com os 03 (três) servidores do CESPE/CEBRASPE e o atual Diretor do CESPE/CEBRASPE contribuíram para o mapeamento das características básicas dos espaços locados por aquele Centro de Seleção e qual critério é utilizado para selecionar o espaço ideal para realização dos eventos.

O CESPE/CEBRASPE informou que não há um perfil exato de espaço físico mínimo que possa ser locado. O espaço é locado de acordo com a demanda do evento, sempre com análise do custo/benefício, podendo variar o tipo de espaço locado conforme as especificidades da região.

Assim, a instituição contraria as duas questões primordiais abordadas por Neves (2008), no que tange a forma administrativa de utilização do espaço público e a necessidade de licitação para tal uso. Por exemplo, concursos a nível nacional como a prova do Exame Nacional do Ensino Médio (ENEM) demandam a locação do máximo de instituições possíveis e nem sempre as instituições terão o mesmo padrão de infraestrutura. Além disso, não se pode comparar, por exemplo, a menor instituição locada no Amazonas com a menor instituição locada no Distrito Federal, haja vista a disparidade de infraestrutura apresentada por esses entes da federação.

De acordo com o CESPE/CEBRASPE, apesar de não haver um modelo básico de estruturas que podem ser locadas, os espaços locados devem possuir o mínimo de infraestrutura, como: energia, água, esgoto, sanitários dentro do estabelecimento, acessibilidade aos portadores de deficiência, dentre outras. 
A dificuldade do CESPE/CEBRASPE em apresentar um modelo padrão de espaço físico apto à locação é apresentado de forma sucinta pela Gráfico 2, a seguir, que exemplifica disparidade de infraestruturas entre uma região e outra, com dados extraídos do Censo Escolar 2014 (instituições públicas e privadas) publicados pelo Instituto Nacional de Estudos e Pesquisas Educacionais Anísio Teixeira (INEP). 


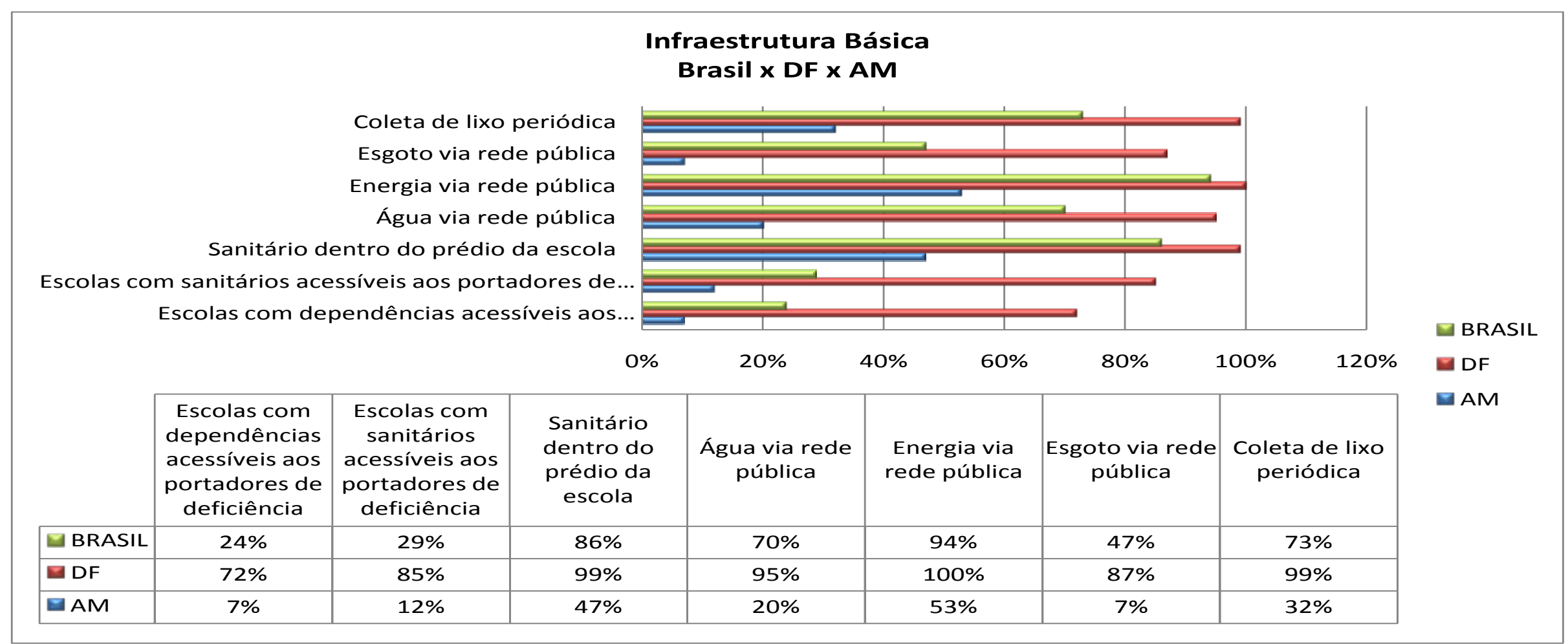

Gráfico 2 - Comparativo de infraestrutura básica: Brasil-Distrito Federal-Amazonas.

Fonte: Censo Escolar (INEP) 2014. 
Entre os itens básicos de infraestrutura, foi possível observar que apenas 47\% das instituições de ensino no Amazonas possuem sanitários dentro da escola e pouco mais de $50 \%$ delas possuem energia via rede pública, ou seja, caso o CESPE/CEBRASPE venha a realizar um evento naquela Unidade da Federação (UF), será enorme a dificuldade de se encontrar estabelecimentos adequados, devido a precariedade dos espaços disponíveis.

Ressalta-se que a disparidade entre o Distrito Federal e o Amazonas poderia ser ainda maior, caso fosse feito a comparação apenas com as instituições de ensino público. Logo, é notória a dificuldade do CESPE/CEBRASPE em definir o perfil ideal ou estrutura mínima para locação de espaço, tendo em vista que essa definição irá variar conforme a região que terá a realização do evento.

Por outro lado, o Distrito Federal apresenta percentuais acima da média nacional, o que credencia uma boa parte das instituições de ensino a estarem aptas a locarem seus espaços, pelo menos no quesito infraestrutura básica.

Ainda sim, mesmo possuindo estrutura básica, de acordo com o CESPE/CEBRASPE, o estabelecimento para ser locado deve possuir carteiras escolares adequadas e em bom estado, possuir o mínimo de 05 (cinco) salas, com capacidade de, pelo menos, 30 alunos por sala, além de, em alguns casos, ter boa localização e salas refrigeradas.

A locação do espaço também vai depender da demanda de inscritos por concursos, sendo que nos concursos de grande porte o CESPE/CEBRASPE utiliza quase todo espaço disponível. Assim, de acordo com Neves (2008), faz-se necessária a abertura de processo licitatório para locação do espaço privado e a permissão do uso do espaço público, por ato administrativo unilateral, de forma gratuita ou onerosa. 
Além disso, a utilização do espaço público também acolhe o princípio da eficiência, impondo à Administração Pública a persecução do bem comum, buscando agir de forma neutra, transparente, eficaz, sem burocracia e sempre em busca da qualidade, primando pela adoção dos critérios legais e morais necessários para melhor utilização dos recursos públicos, evitando desperdícios (MORAES, 2008).

No Distrito Federal, a demanda por concursos se mostra crescente e o CESPE/CEBRASPE cada vez mais atuante nas seleções públicas. A demanda de candidatos no Distrito Federal pode ser melhor observada na Figura 3, a seguir, onde em 2015, a referida UF teve $12,1 \%$ do total de inscritos em seleções realizadas por aquele Centro de Seleção.

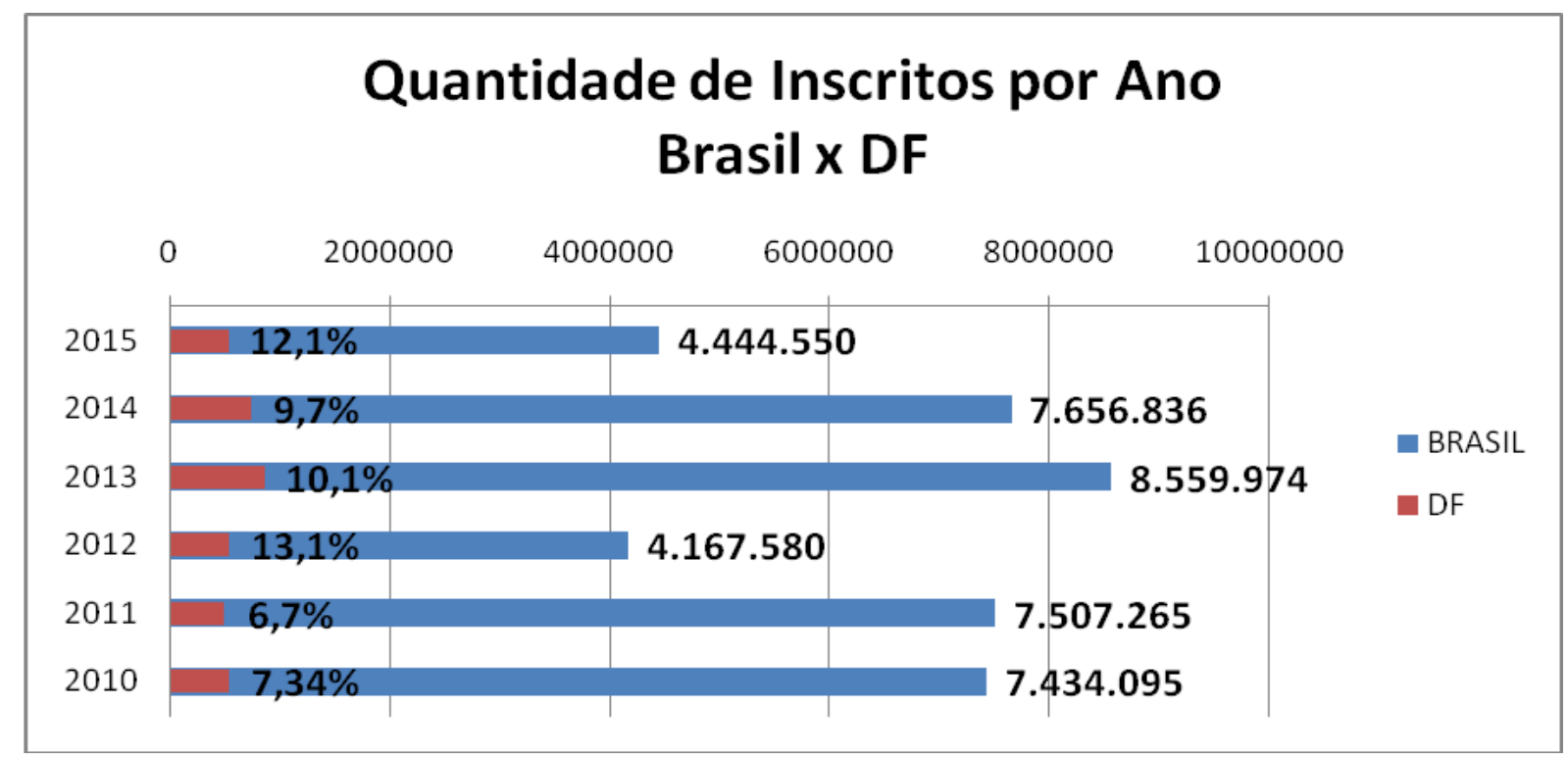

Gráfico 3 - Demanda de inscritos por ano no Brasil e no Distrito Federal.

Fonte: Dos autores, 2016.

Observou-se ainda que no período 2010-2015, o CESPE/CEBRASPE obteve uma média anual de 6.628.383 de candidatos inscritos em suas seleções, sendo que o Distrito Federal, no mesmo período, apresentou uma média anual de 624.525 
inscritos, ou seja, neste período, a demanda de interessados na referida UF em participar de seleções públicas realizadas por aquele Centro de Seleção chega a $10 \%$ to total nacional.

Assim, de acordo com Justen Filho (2009) e Alonso (1999), além da Lei n. 8.666/1993 e da Súmula n. 177 do Tribunal de Contas da União (TCU), faz-se importante que se defina, por meio de norma, qual o critério exato para seleção de um espaço físico para realização de seleções públicas, pois, para que se obtenha o melhor preço em uma determinada contratação, deve haver uma referência de modelo padrão para que o interessado, tanto o público como o privado, possa apresentar seu preço para cessão do espaço, principalmente no Distrito Federal, que tem uma representatividade nas seleções públicas no País e uma demanda crescente de inscritos.

\subsection{Identificar as instituições públicas e privadas do Distrito Federal utilizadas pelo CESPE para a realização de concurso público e comprara os gastos com a locação de espaço físico para a realização dos eventos entre os entes no período 2009-2014}

Identificadas as instituições públicas e privadas, foi possível observar que 83\% das locações de imóveis do CESPE/CEBRASPE são de espaços privados. E que no Distrito Federal esse percentual é de 95\%, ou seja, resta comprovado que o espaço privado é utilizado com maior frequência para realização dos eventos deste centro. 
Entre as instituições privadas que mais arrecadaram no Distrito Federal, destacam-se na Tabela 3, a seguir, as 11 principais que, juntas, receberam mais de $\mathrm{R} \$$ 5.500.000,00 (cinco milhões e quinhentos mil de reais), no período 2009-2014.

Tabela 3 - As dez principais instituições privadas que foram locadas pelo CESPE/CEBRASPE.

\begin{tabular}{lc}
\hline \multicolumn{1}{c}{ Instituições Privadas Locadas pelo CESPE } & Valores \\
\hline Associação Unificada Paulista de Ensino Renovado Objetivo & $\mathrm{R} \$ 685.499,00$ \\
Sociedade Educacional Sul-Rio-Grandense Ltda. & $\mathrm{R} \$ 636.025,90$ \\
Centro de Ensino Unificado de Brasília - UniCEUB & $\mathrm{R} \$ 607.739,40$ \\
IREP Sociedade de Ensino Superior, Médio e Fundamental & $\mathrm{R} \$ 533.064,25$ \\
Liderança Construção e Incorporação Ltda. & $\mathrm{R} \$ 491.502,69$ \\
Sociedade de Ensino Superior Estácio de Sá Ltda. & $\mathrm{R} \$ 486.136,67$ \\
Sociedade Mineira de Cultura & $\mathrm{R} \$ 447.420,20$ \\
CESB - Centro de Educação Superior de Brasília Ltda. & $\mathrm{R} \$ 414.876,20$ \\
Kozcoe Engenharia Ltda. & $\mathrm{R} \$ 405.564,54$ \\
Faculdades Metropolitanas Unidas Educacionais Ltda. & $\mathrm{R} \$ 404.624,60$ \\
Sociedade Educacional Leonardo da Vinci Ltda. & $\mathrm{R} \$ 389.536,50$ \\
\hline Total & $\mathrm{R} \$ \mathbf{5 . 5 0 1 . 9 8 9 , 9 5}$ \\
\hline
\end{tabular}

Fonte: Dos autores, 2016.

Ainda em relação à Tabela 3, foi possível observar que entre as principais instituições existem empresas que não estão ligadas ao ensino, mas que também locaram seus espaços para realização de seleções públicas, seja para armazenamento de itens necessário à promoção do evento (ex: armazenamento de provas) ou pela própria estrutura física apta a receber candidatos aos concursos públicos.

Essa informação pode ser comprovada por meio da descrição da natureza da despesa nos lançamentos contábeis como Nota de Empenho (NE) e Ordem Bancária (OB). A empresa Kozcoe Engenharia Ltda., por exemplo, recebeu recursos 
tanto para locação de galpão (2013NE805641) como para realização de provas, como o ENEN (2012NE802563).

Ainda em relação identificação das instituições privadas, foram utilizadas pelo CESPE/CEBRASPE em todo território nacional, mais de três mil e quinhentas instituições, sendo que no Distrito Federal utilizou-se cerca de 260.

Finalizando as contratações privadas, é importante destacar que foi identificado pagamentos de locação de espaço físico a 02 (dois) Cadastros de Pessoa Física (CPFs), nos exercícios de 2009, 2010 e 2011, que totalizaram cerca de $\mathrm{R} \$ 204.000,00$ (duzentos e quatro mil reais), ou seja, além das empresas privadas houveram pessoas físicas que também receberam valores do CESPE/CEBRASPE e por isso, pelo valor expressivo, foi considerado um cálculo a parte para este tipo de fornecedor contratado.

Já em relação às instituições públicas locadas no Distrito Federal, identificouse que houve estabelecimentos públicos que foram utilizados mais não receberam recursos financeiros, confirmando as informações que o CESPE/CEBRASPE passou por meio de entrevista e resposta escrita.

A baixa utilização do CESPE/CEBRASPE pelo espaço público também é comprovada pelos valores pagos à Secretaria de Estado de Educação do Distrito Federal (SEDF), que totalizou apenas $\mathrm{R} \$ 41.075,00$ para utilização de escolas públicas como, por exemplo, o Centro de Ensino Fundamental 16 (CEF 16) de Ceilândia, o Centro de Ensino Médio 01 (CEM 01) de Sobradinho, o Centro de Ensino 01 (CE 01) do Riacho Fundo, entre outras.

Salienta-se, ainda, que apesar das instituições públicas possuírem um Cadastro Nacional de Pessoa Jurídica (CNPJ) observou-se que, quando o CESPE/CEBRASPE locou os estabelecimentos públicos, os recursos foram 
repassados diretamente para Secretaria de Educação do Estado, como foi o caso do Distrito Federal, que apesar da pouca arrecadação, não se sabe se esses recursos chegaram às escolas que cederam seus espaços para realização de eventos públicos.

Para melhor exemplificar esse fato, após a apuração dos valores pagos pelo CESPE/CEBRASPE aos entes públicos e privados, constatou-se que a Secretaria da Educação do Rio Grande do Sul foi a instituição que mais arrecadou com a locação do espaço físico no Brasil, considerando aqui tanto instituições públicas como privadas. O CESPE repassou a esta secretaria cerca de oito milhões e quinhentos mil reais. Revelando que o Rio Grande do Sul possui uma provável política de otimização dos espaços públicos e comprovando que os estabelecimentos públicos estão aptos a serem utilizados, de forma prioritária, nos concursos públicos.

Cabe ressaltar que a Universidade de Brasília (UnB), apesar de não receber recursos específicos pela cessão do espaço físico para realização dos eventos do CESPE, a mesma recebia recursos por meio de transferência do Fundo de Apoio Institucional (FAl), onde o Centro repassava parte dos recursos arrecadados com a execução dos serviços para UnB, tendo em vista que o CESPE fez parte da estrutura administrativa da Universidade até o final de 2014.

A apresentação dos dados das escolas do Distrito Federal (vide Tabela 4, a seguir) teve embasamento em dados secundários, publicados pelo INEP (2014), por meio do Censo Escolar de 2014. Foi identificado que o Distrito Federal possui 1128 estabelecimentos de ensino na educação básica, sendo 493 privadas (491 na área urbana e 2 na área rural) e 635 públicas (559 na área urbana e 76 na área rural) . Já 
o Ensino Superior possui 60 instituições de ensino, sendo 57 privadas e 03 (três) de ensino públicas, totalizando 1.188 instituições de ensino.

Tabela 4 - Número de estabelecimentos da Educação básica do Distrito Federal.

\begin{tabular}{|c|c|c|c|c|c|c|c|c|c|c|}
\hline \multirow{2}{*}{$\begin{array}{c}\text { Ano } \\
\text { de } \\
\text { Censo }\end{array}$} & \multirow{2}{*}{ UF } & \multicolumn{3}{|c|}{ Urbana } & \multirow{2}{*}{ Total } & \multicolumn{3}{|c|}{ Urbana } & \multirow{2}{*}{ Total } & \multirow{2}{*}{ Tota } \\
\hline & & Federal & Estadual & Privada & & Federal & Estadual & Privada & & \\
\hline 2014 & DF & 9 & 550 & 491 & 1.050 & 1 & 75 & 2 & 78 & 1.128 \\
\hline Total & & 9 & 550 & 491 & 1.050 & 1 & 75 & 2 & 78 & 1.128 \\
\hline
\end{tabular}

Fonte: Censo Escolar (INEP) 2014.

De acordo com CESPE/CEBRASPE, a escolha pelo espaço para realização do evento não se dá por ela ser pública ou privada. A escolha é feita conforme for à demanda dos eventos. Normalmente, as instituições privadas são locadas por apresentarem melhor infraestrutura do que as escolas públicas, não só no Distrito Federal, mas em todos os outros entes da Federação.

Neste sentido, o dado CESPE/CEBRASPE condiz com os dados de infraestrutura apresentadas pelo INEP (2014), por meio do Censo Escolar 2014, onde se pode fazer uma comparação das estruturas das instituições públicas e privadas.

Segundo o Censo Escolar 2014, foram avaliadas no Brasil 188.673 escolas da educação básica, sendo 149.098 públicas e 39.575 privadas, que tiveram os seguintes resultados: 


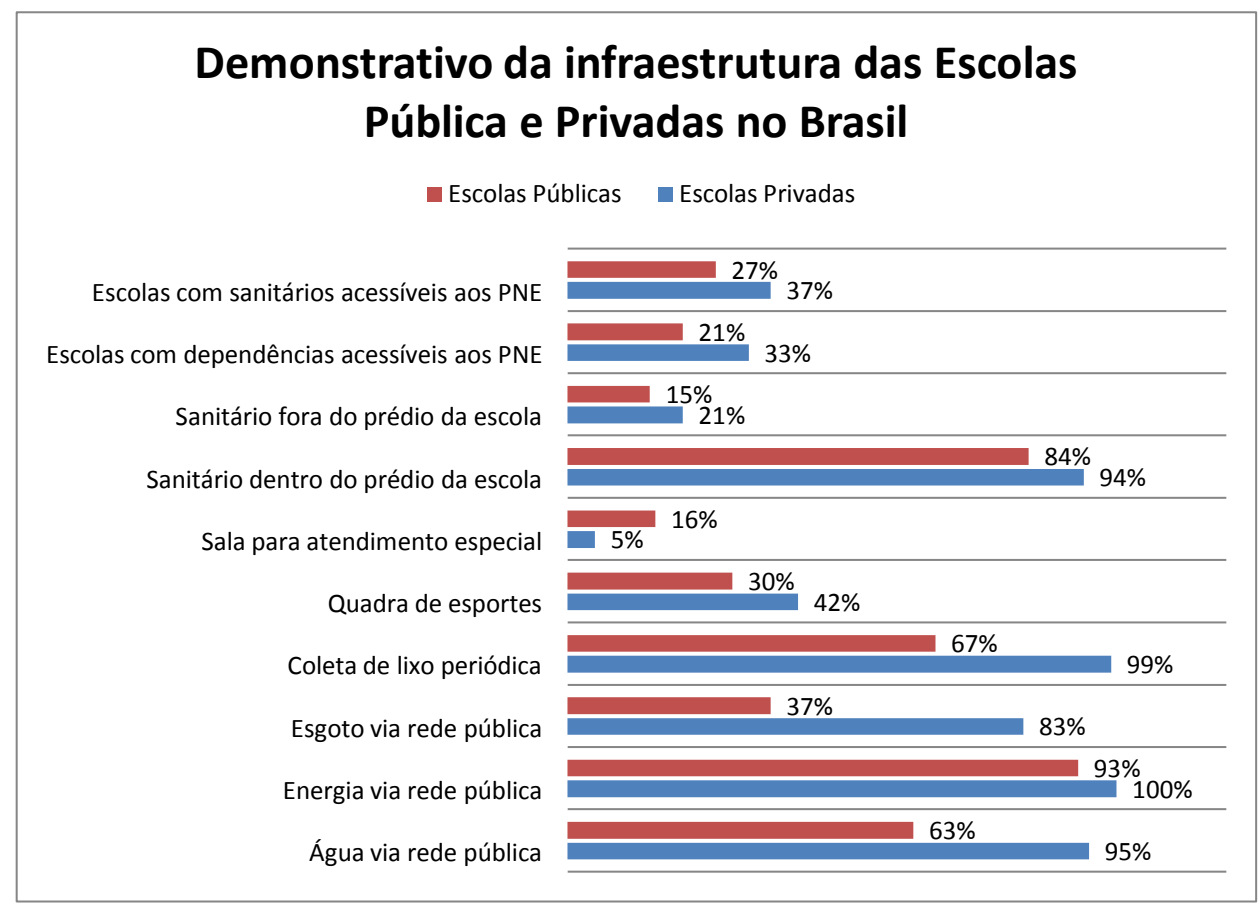

Gráfico 4 - Demonstrativo da infraestrutura das escolas públicas e privadas da Educação Básica no Brasil.

Fonte: Censo Escolar (INEP) 2014.

É possível observar no Gráfico 4 uma discrepância em nível nacional das estruturas das escolas públicas e privadas. Percentuais como coleta de lixo periódica, esgoto via rede pública e água via rede pública apresentam índices baixos e demonstram as precárias infraestruturas das escolas do ensino básico no País. Por outro lado, verifica-se que, em nível nacional, 16\% das escolas públicas possuem salas de atendimento especial, enquanto que as escolas privadas possuem apenas $5 \%$.

A discrepância entre as instituições públicas e privadas no Distrito Federal diminuem, justamente pelo fato de que a referida UF possui, em suas instituições públicas, uma das melhores infraestruturas do País. Porém, ainda não apresenta as 
mesmas condições das instituições privadas, conforme apresentado no Gráfico 5, a seguir.

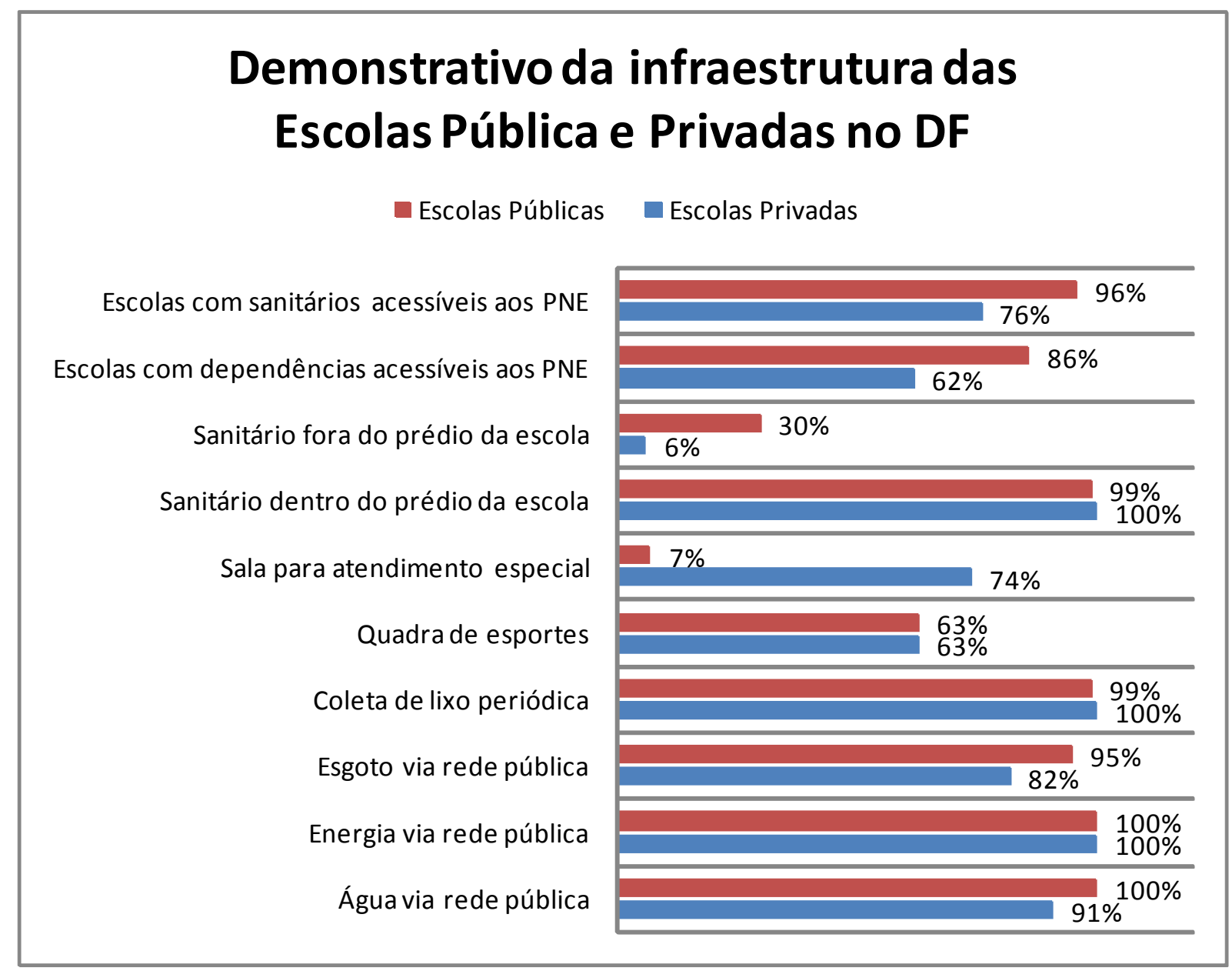

Gráfico 5 - Demonstrativo da infraestrutura das escolas públicas e privadas da Educação Básica no Distrito Federal.

Fonte: Censo Escolar 2014 - MEC/INEP/DEED.

Com base no Gráfico 5, é possível observar que as instituições públicas do Distrito Federal, possuem infraestrutura básica similar às escolas privadas da educação básica. Porém, ao contrário do que apresentou o gráfico da infraestrutura das escolas no Brasil (Figura 5), as escolas públicas do Distrito Federal apresentam alguns indicadores superiores aos do ensino privado, principalmente quanto ao acesso especial, como é o caso dos sanitários especiais aos PNE (pública 96\% e 
privada 76\%), dependências acessíveis aos PNE (pública 86\% e privada 62\%) e as salas de atendimento especial onde as escolas do ensino público possuem $74 \%$ e as privadas $7 \%$.

Isto posto, o Gráfico 5 demonstra que o ensino público do Distrito Federal, além de ter uma infraestrutura acima da média nacional, as dependências das escolas públicas estão cada vez mais estruturadas para atender o aluno especial, item também exigido pelo CESPE/CEBRASPE para locação do espaço físico.

Desse modo, além da análise dos dados do Censo Escolar 2014, com as visitas às instituições de ensino, foi possível verificar que diversas escolas públicas do Distrito Federal oferecem requisitos básicos de infraestrutura, como capacidade mínima de 30 alunos por sala, carteiras escolares em bom estado, salas arejadas, dentre outros requisitos.

Entretanto, sabendo da disponibilidade do espaço público, o CESPE/CEBRASPE alega que nem sempre as instituições de ensino público estão disponíveis ou tem interesse em locar seus espaços. O CESPE/CEBRASPE cita, por exemplo, o caso da Escola Militar da Asa Norte, que possui excelentes instalações e atenderia boa parte das seleções realizadas por este Centro, porém, esta escola, por diversas vezes já negou a utilização do espaço justificando que teria atividades aos finais de semana, período em que ocorrem os concursos públicos.

Além disso, segundo o CESPE/CEBRASPE, em eventos de grande porte e de interesse do Ministério da Educação, por exemplo o ENEM, o próprio órgão emite um ofício solicitando a disponibilidade do espaço, bem como a gratuidade da mesma, cabendo ao Estado e o Município aceitar ou não a solicitação. É por isso, que em alguns eventos o CESPE/CEBRASPE não repassa recursos financeiros para instituição pública, havendo apenas o envio de materiais básicos de limpeza e 
conservação para realização do evento, denominado pelo Centro como uma espécie de "kit de material de limpeza", ou seja, uma espécie de permuta em benefício da seleção pública.

A UnB é um exemplo das instituições públicas mais utilizadas pelo CESPE/CEBRASPE para realização de eventos. Porém, não é utilizada em sua totalidade. A UnB, segundo o anuário estatístico 2015, utilizando o mesmo critério das escolas do ensino básico (maior capacidade por turno) comporta cerca de 26.083 alunos, em salas distribuídas em seus 04 (quatro) campus: Darcy Ribeiro (Plano Piloto), Planaltina, Ceilândia e Gama.

A rigor, se levarmos em conta o espaço físico disponível pela UnB, segundo o Plano de Desenvolvimento Institucional (PDI) de 2014 a 2017, apenas no campus Darcy Ribeiro, que possui boas instalações, além de excelente localização com capacidade para mais de 10 mil alunos (sem contar anfiteatros com capacidade para mais de 2500 alunos), teria espaço suficiente para realizar cerca de $75 \%$ dos eventos executados pelo CESPE/CEBRASPE no período de 2010 à 2015, ou seja, das 320 seleções feitas neste período, apenas 88 tiveram acima de dez mil inscritos.

$\mathrm{Na}$ UnB, um dos prédios mais utilizados para concurso público são os Pavilhões João Calmon e Anísio Teixeira, que possuem estruturas similares com capacidade para atender mais 2.500 alunos (vide Apêndice "B").

As salas dos os Pavilhões João Calmon e Anísio Teixeira possuem o mesmo tamanho e as mesmas características, com capacidade para até 50 alunos ou candidatos, bem acima do quantitativo mínimo estabelecido pelo CESPE/CEBRASPE. Além disso, as salas, apesar de não possuírem ar refrigerado, possuem boa ventilação e iluminação. 
O CESPE/CEBRASPE também exige carteiras escolares de tamanho padrão, em bom estado e que possam dá o mínimo de conforto ao candidato. O que também é atendido nas salas do Pavilhão João Calmon, bem como na maioria das estruturas da UnB.

Outra instituição pública que atende às exigências do CESPE/CEBRASPE é o Instituto Federal de Brasília (IFB), que possui prédios novos e estrutura igual ou melhor que a UnB e que também é um espaço útil para realização de seleções públicas, haja vista que possui campus espalhados por diversas regiões do Distrito Federal, como Plano Piloto, Ceilândia, Gama, Planaltina, Riacho Fundo, Samambaia, São Sebastião, Taguatinga e Taguatinga Centro, com mais de 500 salas disponíveis e capacidade de atendimento, por turno, de mais de cinco mil alunos.

Ainda sim, mesmo com essa estrutura, e boa localização como o campus IFB Brasília/Plano, com capacidade de cerca de 1300 alunos, não é utilizado para realização de seleções públicas. Para se ter uma ideia, em 2015 o CESPE/CEBRASPE realizou 63 seleções públicas, sendo que 18 delas não tiveram mais de 1.100 inscritos, logo, pelo espaço público disponível, somente o IFB (campus Brasília/Plano) poderia atender aproximadamente $28 \%$ dos concursos realizados pelo CESPE/CEBRASPE em 2015, pois concursos como o de Procurador do TCU, que obteve apenas 563 inscritos se enquadrariam em concurso de pequeno porte e se adéquam as estruturas dos espaços públicos disponíveis.

Do mesmo modo, as 10 (dez) visitas às escolas públicas ratificaram os dados do Censo Escolar 2014, que apresentam as escolas do ensino básico no Distrito Federal com infraestrutura acima da média nacional e, por isso, também apresentam 
estrutura adequada para realização de concursos públicos, conforme é ilustrado no (vide Anexo "E").

Desse modo, observou-se que existem escolas públicas no Distrito Federal que atendem as demandas do CESPE/CEBASPE quanto às características básicas de infraestrutura, bem como não deixam a desejar se comparadas com as instituições privadas mais locadas pelo Centro para realização de eventos, como é o caso do Centro Universitário de Brasília (UniCEUB), o Centro de Educação Superior de Brasília (CESB) e a Sociedade Educacional Leonardo da Vinci, quem tem uma de suas salas ilustradas no Apêndice "B" da presente pesquisa.

Por meio da entrevista, também foi relatado pelo CESPE/CEBRASPE que as instituições públicas no Distrito Federal, apesar de possuírem espaços físicos adequados, com capacidade que atenda a demanda de um determinado evento, não possuem carteiras em bom estado, o que pode inviabilizar a utilização desse espaço ou aumentar os custos do Centro na execução do evento, haja vista que terão que locar carteiras para disponibilizar nesta instituição. O que já ocorreu em várias oportunidades.

Isto posto, a justificativa do CESPE/CEBRASPE não condiz com a realidade das instituições de ensino no Distrito Federal já destacadas anteriormente por meio do Censo Escolar 2014. Porém, como o Censo Escolar não trás informações sobre qualidade de carteira ou quantitativo defeituoso, não se pode afirmar que todas as escolas possuem carteiras adequadas para realização de um concurso público.

Assim, por meio do confronto de informações obtidas nos órgãos públicos ligados a educação, dados estatísticos do Censo Escolar 2014, visitas por amostra nas instituições de ensino e as informações das entrevistas com os servidores do 
CESPE/CEBRASPE, resta comprovado a similaridade de infraestrutura oferecidas nas instituições do ensino público e privado do Distrito Federal.

Já os dados apresentados na Tabela 5, a seguir, demonstram que no período 2009-2014, o gasto do CESPE/CEBRASPE com locação de espaço físico foi de R\$ 53.716.623,22, sendo que $\mathrm{R} \$ 44.883 .812,30$ foram destinados às instituições privadas, e apenas $\mathrm{R} \$$ 8.628.951,92 foram destinados às instituições públicas, com a apuração de pagamentos no montante de $\mathrm{R} \$ 203.849,00$ para pessoa física.

A média de gasto anual foi de $\mathrm{R} \$ 8.952 .768,87$, sendo $\mathrm{R} \$ 7.480 .635,38$ com a área privada e $\mathrm{R} \$ 1.438 .158,65$ com a área pública. Logo, mais de 83\% das despesas com locação de espaço físico para realização de eventos foram destinados às instituições privadas, 16\% para empresas públicas e 0,38\% para pessoa física.

Tabela 5 - Despesa com locação de espaço público e privado no Brasil (em R\$).

\begin{tabular}{ccrrr}
\hline Ano & Pessoa Física & \multicolumn{1}{c}{ Público } & \multicolumn{1}{c}{ Privado } & \multicolumn{1}{c}{ Total } \\
\hline 2009 & $\mathrm{R} \$ 88.000,00$ & $\mathrm{R} \$ 40.430,50$ & $\mathrm{R} \$ 5.891 .544,47$ & $\mathrm{R} \$ 6.019 .974,97$ \\
2010 & $\mathrm{R} \$ 96.000,00$ & $\mathrm{R} \$ 196.776,70$ & $\mathrm{R} \$ 10.771 .882,53$ & $\mathrm{R} \$ 11.064 .659,23$ \\
2011 & $\mathrm{R} \$ 19.849,00$ & $\mathrm{R} \$ 3.542 .563,24$ & $\mathrm{R} \$ 4.273 .619,78$ & $\mathrm{R} \$ 7.836 .032,02$ \\
2012 & - & $\mathrm{R} \$ 327.334,20$ & $\mathrm{R} \$ 6.865 .510,04$ & $\mathrm{R} \$ 7.192 .844,24$ \\
2013 & - & $\mathrm{R} \$ 3.900 .046,97$ & $\mathrm{R} \$ 6.775 .026,55$ & $\mathrm{R} \$ 10.675 .073,52$ \\
2014 & - & $\mathrm{R} \$ 621.800,31$ & $\mathrm{R} \$ 10.306 .228,93$ & $\mathrm{R} \$ 10.928 .029,24$ \\
Total & $\mathbf{R} \mathbf{2 0 3 . 8 4 9 , 0 0}$ & $\mathbf{R} \mathbf{8 . 6 2 8 . 9 5 1 , 9 2}$ & $\mathbf{R} \mathbf{4 4 . 8 8 3 . 8 1 2 , 3 0}$ & $\mathbf{R} \mathbf{5 3 . 7 1 6 . 6 1 3 , 2 2}$ \\
\hline
\end{tabular}

Fonte: Dos autores, 2016.

Já no Distrito Federal, conforme apresentado na Tabela 6, a seguir, no mesmo período, o CESPE/CEBRASPE gastou com locação de espaço físico R\$ 8.717.563,65, sendo que $\mathrm{R} \$$ 8.272.083,34 com a contratação de instituições privadas, e somente $\mathrm{R} \$ 445.480,31$ foram destinados às instituições públicas. 
No Distrito Federal, a média de gasto com locação de espaço foi de $R \$$ 1.452.927,28, sendo as instituições privadas com média de $R \$ 1.378 .680,56$, e as instituições públicas com a média de R\$ 74.246,72. Ou seja, no Distrito Federal, o gasto com locação de espaço físico de instituições privadas passou a ser de 95\% contra $5 \%$ dos estabelecimentos públicos.

Tabela 6 - Despesa com locação de espaço público e privado no Distrito Federal (em R\$).

\begin{tabular}{cccc}
\hline Ano & Público & Privado & Total \\
\hline 2009 & - & $\mathrm{R} \$ 1.875 .064,80$ & $\mathrm{R} \$ 1.875 .064,80$ \\
2010 & - & $\mathrm{R} \$ 2.056 .456,33$ & $\mathrm{R} \$ 2.056 .456,33$ \\
2011 & - & $\mathrm{R} \$ 549.636,83$ & $\mathrm{R} \$ 549.636,83$ \\
2012 & $\mathrm{R} \$ 7.302,00$ & $\mathrm{R} \$ 650.834,85$ & $\mathrm{R} \$ 658.136,85$ \\
2013 & $\mathrm{R} \$ 72.029,00$ & $\mathrm{R} \$ 643.618,70$ & $\mathrm{R} \$ 715.647,70$ \\
2014 & $\mathrm{R} \$ 366.149,31$ & $\mathrm{R} \$ 2.496 .471,83$ & $\mathrm{R} \$ 2.862 .621,14$ \\
Total & $\mathbf{R} \mathbf{4 4 5 . 4 8 0 , 3 1}$ & $\mathbf{R} \mathbf{8 . 2 7 2 . 0 8 3 , 3 4}$ & $\mathbf{R} \mathbf{8 . 7 1 7 . 5 6 3 , 6 5}$ \\
\hline
\end{tabular}

Fonte: Dos autores, 2016.

Diante do exposto, é possível constatar que mesmo havendo disponibilidade de espaço público, o CESPE/CEBRASPE prioriza a contratação das instituições privadas. Tal discrepância de gastos entre entes públicos e privados é melhor observada nos Gráficos 6 e 7, a seguir. 


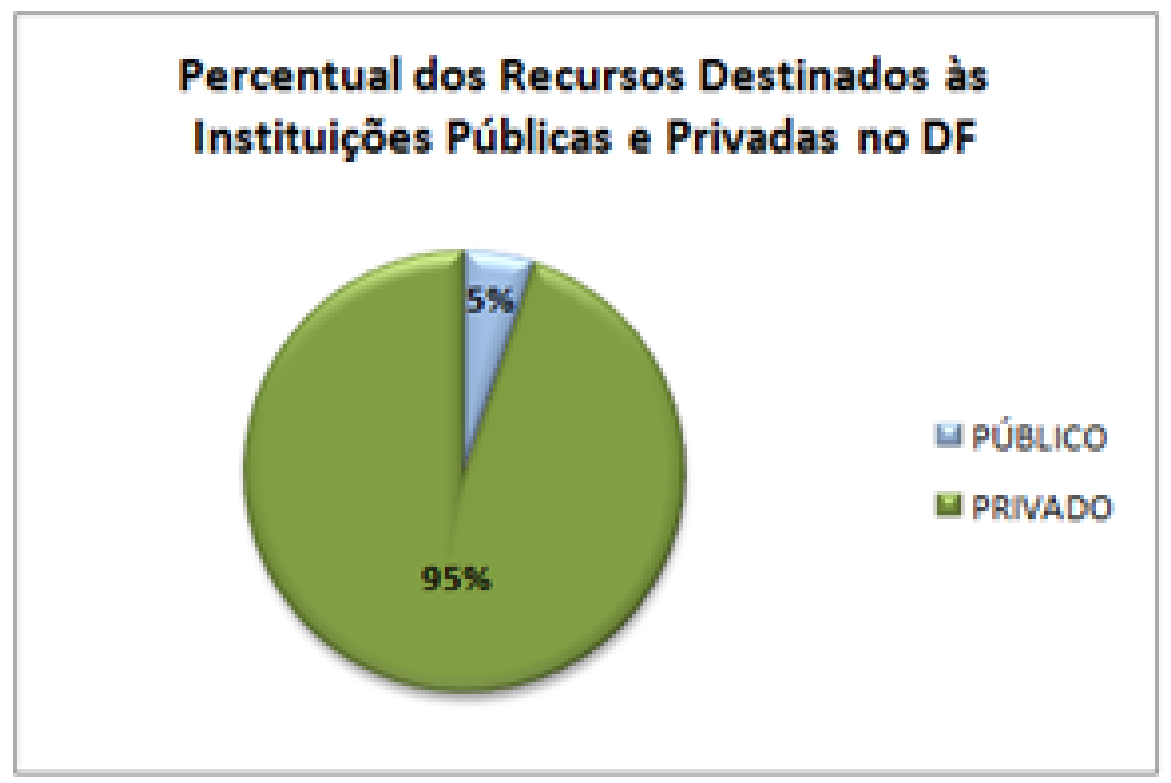

Gráfico 6 - Percentual dos recursos destinados às instituições públicas e privadas no Distrito Federal. Fonte: Dos autores.

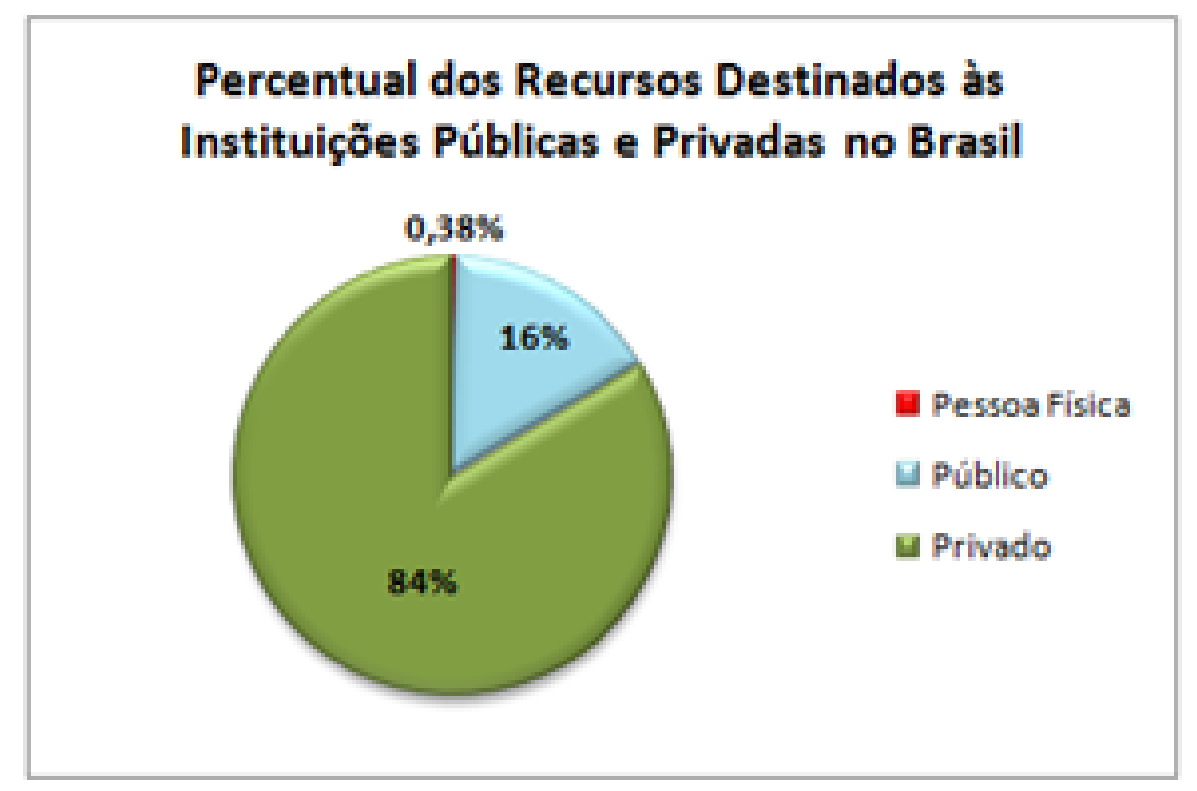

Gráfico 7 - Percentual dos recursos destinados às instituições públicas e privadas no Brasil. Fonte: Dos autores.

Neste sentido, é possível notar que as seleções públicas realizadas pelo CESPE/CEBRASPE tendem a serem realizadas nas dependências de instituições privadas e que as instituições públicas pouco são empregadas nesses eventos. 
Então, mesmo o Distrito Federal possuindo instituições públicas com infraestrutura acima da média nacional, onde, apenas o campus Darcy Ribeiro na UnB poderia atender $75 \%$ dos concursos realizados pelo CESPE/CEBRASPE, não há uma expectativa de que este cenário possa mudar, pois, apesar de observarmos uma crescente utilização dos espaços públicos, a utilização dos espaços privados também crescem ao mesmo passo que também crescem as seleções públicas.

\subsection{Demonstração da evolução dos recursos recebidos pelo} CESPE/CEBRASPE e os gastos com locação de espaço físico para a realização de concurso público no período 2009-2014

Em consulta ao Sistema Integrado de Administração Financeira (SIAFI) do Governo Federal e ao Portal da Transparência, observou-se a evolução dos recursos do CESPE/CEBRASPE entre os anos 2000 e 2014. Os dados mostram que a arrecadação aumentou mais de 63\%.

A crescente arrecadação do CESPE/CEBRASPE nos últimos anos (2009 a 2014), como se pode verificar no Gráfico 8, a seguir, fez com que essa unidade se firmasse como indispensável para o desenvolvimento das atividades da UnB, sendo que em 2013 o referido Centro de Seleção chegou próximo à arrecadação de R\$ 400.000.000,00 (quatrocentos milhões de reais). 


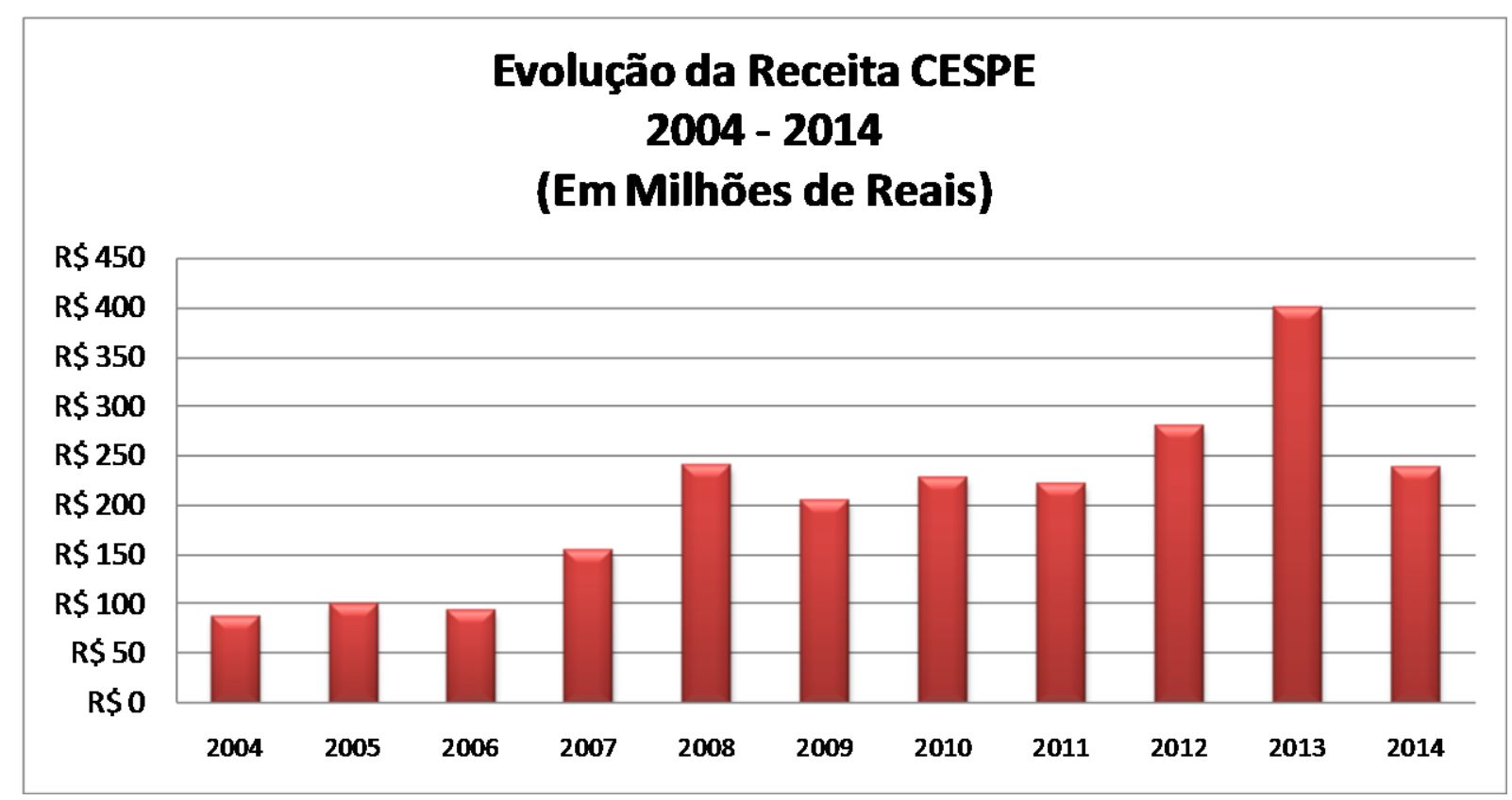

Gráfico 8 - Histórico de arrecadação do CESPE/CEBRASPE - período 2004-2014.

Fonte: Dos autores.

No Gráfico 9 é possível observar a evolução da receita do CESPE/CEBRASPE de 2004 a 2014. Em 11 anos, o Centro criado pela Fundação Universidade de Brasília (FUB), a fim de realizar eventos e seleções, passou a ter arrecadações crescentes, haja vista que no serviço público federal, conforme Boletim Estatístico de Pessoal (BRASIL, 2015), totalizou mais de 155.500 novos servidores, ou seja, essa crescente na receita, de fato se deve a política de governo adotada neste período que optou em fortalecer o quadro de pessoal estatal, ingressando 201,35\% servidores públicos a mais do que o período do governo anterior. 


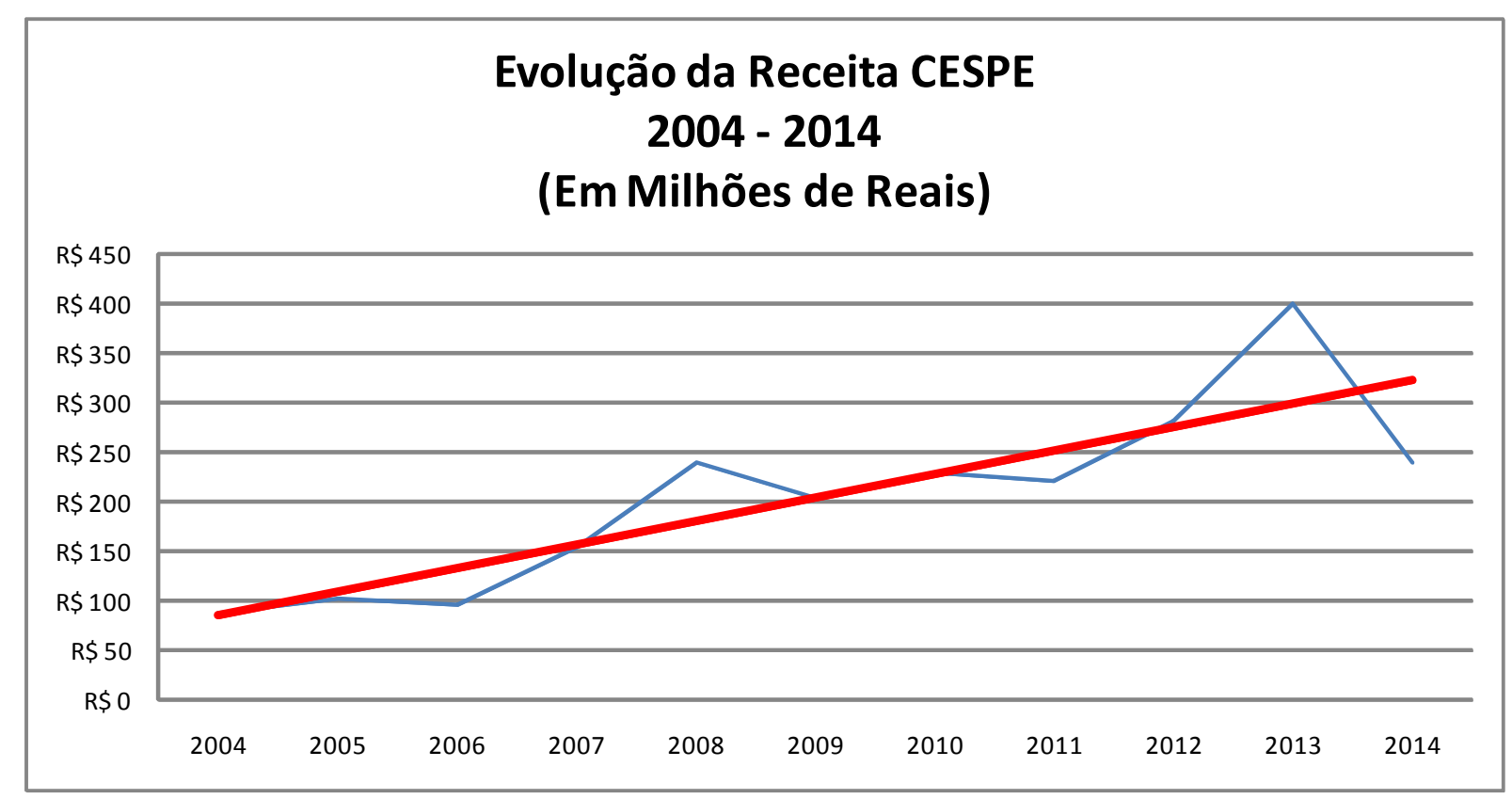

Gráfico 9 - Linha de tendência na arrecadação do CESPE/CEBRASPE - período 2004-2014. Fonte: Dos autores.

Isto posto, a crescente receita do CESPE/CEBRASPE é ratificada pela linha de tendência apresentada no Gráfico 7. Contudo, apesar de que o histórico da receita apresenta uma inclinação próspera, alavancada pela receita recorde atingida no ano de 2013, o exercício de 2014 apresentou uma queda brusca, o que pode ser justificado por 03 (três) motivos básicos: primeiro, o ano de 2014 foi um ano marcado por ajustes fiscais, cortes de gastos e diversos problemas com as contas públicas, não somente no Governo Federal, mas, também, nos Estados e Municípios; segundo, diversos estados (ex: Distrito Federal, Rio Grande do Sul e Santa Catarina) e municípios (Porto Alegre, Palmas e São Paulo) passavam por problemas com limite de despesa com pessoal estabelecidos na Lei de Responsabilidade Fiscal (LRF), ou seja, muitos desses entes da Federação tinham atingido o percentual máximo da despesa ou estavam no limite prudencial, ficando, assim, impedidos de contratar novos servidores e, consequentemente, de realizar 
novos concursos, o que afetava diretamente o ramo de atividade do CESPE/CEBRASPE.

Por fim, devido à reestruturação do CESPE para CEBRASPE, sendo instituída a Organização Social (OS), no ano de 2014, o CESPE/CEBRASPE deixou de assinar novos contratos até que sua estrutura estivesse em pleno funcionamento, executando apenas contratos já assinados anteriormente pelo CESPE.

O Gráfico 10, a seguir, apresenta a evolução das despesas do CESPE/CEBRASPE com locação de espaço físico, que chegaram a quase treze milhões de reais empenhados anualmente. 


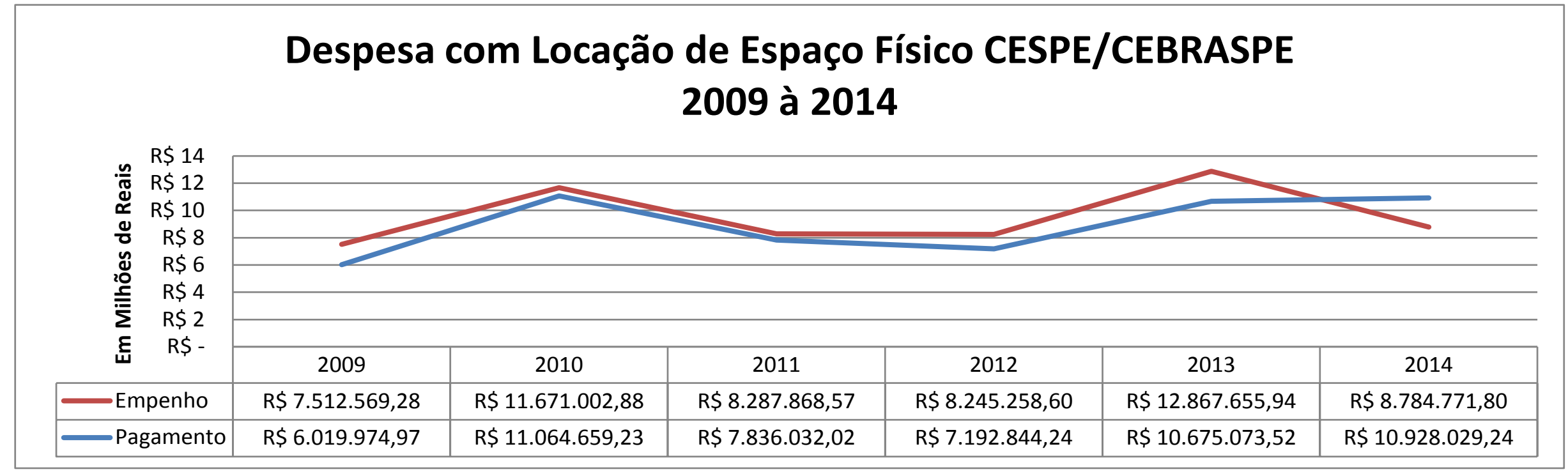

Gráfico 10 - Histórico da despesa do CESPE/CEBRASPE com locação de espaço físico - período 2009-2014.

Fonte: Dos autores. 
Tendo como base os últimos 06 (seis) anos (2009 a 2014), observa-se que o CESPE/CEBRASPE empenha, em média, pouco mais de nove milhões e quinhentos mil reais por ano para locar espaços físicos para realização dos seus eventos.

Observa-se ainda na Gráfico 10 que o Empenho e o Pagamento seguem uma linha correlata e que em todos os exercícios o primeiro é maior que o segundo, haja vista que a execução da despesa passa por três fazes distintas: Empenho, Liquidação e Pagamento. Portanto, o empenho antecede ao pagamento e o ideal é que ambos andem em linhas semelhantes, como, por exemplo, o que ocorreu em 2011, quando um valor ficou bem próximo do outro.

Quando há uma desafinação dessas linhas como ocorre em 2013 o CESPE/CEBRASPE deixa um maior volume de despesas em restos a pagar, o que por esse motivo, juntamente com o acumulo dos exercícios anteriores (quem também deixaram restos a pagar), fez com que a linha de pagamento ultrapassasse a linha de empenho no exercício de 2014, liquidando os compromisso e obrigações, conforme já destacado anteriormente, para atender as mudanças de sua natureza jurídica (criação da OS) que ocorreu nesse período.

Esses valores se comparados à receita anual podem chegar até $5 \%$ do faturamento do centro, logo, a utilização de espaços públicos podem, também, contribuir para otimização dos custos na realização dos eventos do CESPE/CEBRASPE, haja vista que a maior parte dessa despesa foi realizada com locação de instituições privadas.

Assim, mesmo que o uso dos espaços físicos das instituições públicas demandassem alocação de recursos, não havendo, portanto, redução de gastos, os valores transferidos para essas instituições, poderiam contribuir com a qualidade do 
ensino, caso fossem aplicados, por exemplo, em infraestrutura. Pois, conforme já abordado por Passador, Yoshimoshi e Artoni (2011), trata-se de uma determinante na qualidade do ensino.

\subsection{Descrição das instituições públicas com os critérios e características utilizados pelo CESPE/CEBRASPE para definir a contratação/locação de espaço para concurso público no Distrito Federal}

Com base nos critérios e nas características similares dos espaços contratados pelo CESPE/CEBRASPE no período 2009-2014, foi identificado que, somente do ensino básico público, 339 instituições no Distrito Federal possuem espaço físico similar ao menor espaço físico que o CESPE/CEBRASPE contratou recentemente para aplicar as provas do ENEM 2014.

A escola utilizada como base foi a Escola Classe Dom Bosco, localizada na região do Itapoã, que, de acordo com o Censo Escolar 2014, já considerando apenas as salas ativas (ou utilizáveis), possui 08 (oito) salas com capacidade de, pelo menos, 195 alunos.

Para o CESPE/CEBRASPE, a capacidade dessa escola seria de apenas 04 (quatro) salas úteis e capacidade de 112 alunos, conforme foi a demanda de inscritos para esta instituição para realização do ENEM 2014.

Assim, por haver uma divergência do CESPE/CEBRASPE e o Censo Escolar 2014 pela capacidade real da escola, onde aquele Centro alega que deve haver salas de apoio e reservas disponíveis, o cálculo da disponibilidade do espaço físico disponível foi feito pelo quantitativo de salas maior que o dobro da quantidade 
mínima de salas exigidas pelo Centro, ou seja, foram selecionadas apenas escolas com, pelo menos, 10 salas ativas.

Salienta-se que dessas 339 escolas, já foram excluídos os espaços das instituições de ensino de nível infantil e creches, bem como todas aquelas dependências de Ensino Médio e Fundamental que não atenderam o mínimo 10 salas, calculados por meio da quantidade de turmas ativas.

A capacidade das salas das instituições deu-se por meio de alunos matriculados e turmas, pois conforme apresentado nos tratamentos dos dados, o quantitativo de salas publicado pelo Censo Escolar, não é igual à quantidade de salas ativas, pois por meio de visita de campo, observou-se que algumas salas de aulas foram ocupadas para outros fins, como por exemplo, sala de professores, sala de informática, arquivo, refeitório, lanchonetes, entre outras. O que reduz a capacidade da escola.

Assim, tendo em vista que as escolas públicas do Distrito Federal, segundo a SEDF, estão, em sua maioria, com sua capacidade máxima, o número de alunos matriculados por turno (selecionando o maior deles) foi a forma de se obter como capacidade real da instituição de ensino, sendo esta, suficiente para compararmos com as instituições privadas locadas pelo CESPE/CEBRASPE.

É preciso observar que a quantidade de instituições públicas, do ensino básico, aptas a receber os eventos do CESPE/CEBRASPE caem quando inserido outro requisito básico do centro: salas com capacidade média de 30 alunos. Assim, o número de estabelecimentos que atendem aos critérios mínimos (espaço similar à Escola Classe Dom Bosco, Itapoã) é de 164, com capacidade de mais de 107 mil alunos/candidatos. Porém, acredita-se que não se pode descartar outras instituições de ensino que, além de possuir uma boa média de alunos por sala, possuem grande 
quantidade de salas, podendo atender outros requisitos básicos, como logística e concentração de candidatos em uma mesma unidade locada.

Dessa forma, foi identificado que, além das instituições públicas de ensino superior, como a UnB e o IFB, existem instituições públicas do ensino básico que atendem aos critérios exigidos pelo CESPE/CEBRASPE para locação do espaço físico, cabendo ao centro, selecionar os espaços de acordo com a demanda dos eventos, seja ele de grande ou pequeno porte. 


\section{CONCLUSÕES}

Conforme a pesquisa aqui empreendida, foi possível observar que o Centro de Seleção e Promoção de Eventos/Centro Brasileiro de Pesquisa em Avaliação e Seleção e de Promoção de Eventos (CESPE/CEBRASPE) não possui um critério definido ou normatizado para selecionar um espaço físico para a locação de um evento qualquer. Pois, apesar de possuir uma lista com capacidade das instituições públicas e privadas do Brasil e do Distrito Federal, não se tem um documento que especifique as características básicas ou mínimas que a instituição deve atender para que seja contratada.

Mesmo não havendo critério para a locação de um espaço, foi possível identificar, por meio dos gastos com a locação de espaço, as instituições públicas e privadas do Distrito Federal que são utilizadas pelo CESPE/CEBRASPE. Contudo, constatou-se que além dessas, houve pagamento, também, à pessoa física.

Observou-se ainda que o CESPE/CEBRASPE é certamente uma das maiores bancas de seleções públicas do Brasil, não somente pelo volume de recursos arrecadados, mas também pela quantidade de seleções realizadas de 2009 a 2014 no País (PATI, 2013).

A crescente demanda por concurso público e a arrecadação do CESPE/CEBRASPE ratificam a necessidade de uma legislação específica para regulamentar tanto as seleções como a forma de contratação das bancas organizadoras. Pois, mesmo com a mudança das características do governo atual que optou pelo fortalecimento do quadro estatal -, as seleções públicas perdurarão na Administração Pública devido a obrigatoriedade estabelecida na Carta Magna de 1988. 
Por meio dos gastos com locação de espaço físico, constatou-se que o CESPE/CEBRASPE prioriza a contratação do espaço privado ao invés do público, mesmo que este possua espaço similar ao contratado. Ressalta-se aqui a verificação de um processo discricionário do Centro para a seleção dos locais onde serão realizados seus eventos, com a justificativa de ora por exigências dos clientes, ora por logística.

Verificou-se que existem instituições públicas que cedem o espaço para realização de seleções públicas sem nenhum custo para o CESPE/CEBRASPE, que, por sua vez, disponibiliza para estas uma espécie de "kit de material de limpeza", como forma de permuta pela utilização do espaço. Por outro lado, também há instituições públicas que locam seus espaços e recebem recursos financeiros pela cessão de espaço, confirmando o que fora antecipado como verdade provisória nas hipóteses diretrizes. Todavia, no caso do Distrito Federal, os valores pagos foram efetuados em nome da Secretaria de Estado de Educação do Distrito Federal (SEDF) e, por esse motivo, não se sabe se esses recursos chegaram às instituições públicas locadas.

O Distrito Federal possui espaço físico público que atende as exigências mínimas do CESPE/CEBRASPE para a locação de espaço para eventos diversos, bem como possui instituições de ensino com características similares aos espaços privados. Conforme os resultados aqui logrados, atualmente, pelo menos 164 escolas do ensino básico com capacidade de mais de 167 mil alunos estão aptas a serem utilizadas em seleções públicas, além das instituições de Ensino Superior e Técnico, como, por exemplo, a Universidade de Brasília (UnB) e o Instituto Federal de Brasília (IFB). 
As instituições de ensino básico (níveis Fundamental e Médio) do Distrito Federal possuem infraestruturas acima da média nacional, o que credencia as instituições, por terem similaridades nas suas estruturas físicas, a uma possível concorrência entre as mesmas, locando seus espaços em períodos ociosos e obtendo recursos financeiros que poderão ser aplicados em indicadores determinantes para a melhoria da qualidade do ensino.

Por fim, devido à oferta de espaço público ser similar nas instituições, tornar obrigatório, por meio de legislação específica, a utilização de espaço público para realização de concurso público, pode trazer inúmeros benefícios à sociedade, por meio da melhoria da educação, pois, estimular a competição entre as instituições públicas para locar seus espaços, além de ser inovadora, faria com que estas zelassem pelo seu patrimônio e buscassem sempre melhorá-lo; ou seja, quanto melhor suas estruturas, mais chance teriam de ser locadas.

Apesar de não ter sido comprovado tal situação no presente trabalho, há indícios de que a competitividade é plenamente viável na Administração Pública, contrariando a regra atual e seguindo um novo caminho: o da Administração Pública gerencial ou nova gestão pública (new public management). 


\section{RECOMENDAÇÕES}

Tendo em vista a crescente demanda por concursos públicos no Brasil, as linhas que se seguiram observaram que algumas situações outrora apresentadas carecem de pesquisa profunda, uma vez que, apesar do vasto acervo de material bibliográfico sobre a locação de espaço público e métodos de seleção pública, pouco se viu sobre a logística e, principalmente, quanto à locação de espaços para realização de concurso público. Além disso, há uma serie de entendimentos jurídicos quanto à forma de locação de espaço privado por agente público, quando há tempo, a Administração Pública interpreta a dispensa de licitação com a inexigibilidade, onde esta carece de inviabilidade de competição.

Observou-se também contratações diretas, por meio de dispensa de licitação, fundamenta-se basicamente em 03 (três) incisos do art. 24, da Lei n. 8.666/1993, sendo eles o I, II e X. Sendo o que teve maior frequência foi o inc. II, com 3.283 contratações, com uma das justificativas mais utilizadas na Administração Pública, quando se trada de dispensa de licitação: contratações iguais ou inferiores aos 10\% do limite previsto na alínea "a", do inc. II do art. 23, da Lei n. 8.666/1993, ou seja, contratações com valores inferiores ou iguais à $R \$ 8.000,00$ (oito mil reais).

Por outro lado, há 20 empenhos com a justificativa no inc. I. Contudo, o inc. I do art. 24 da referida Lei estabelece que aquele artigo possa atender a administração, para obras e serviços de engenharia de valor até $10 \%$ do limite previsto na alínea "a", do inc. I do art. 23. Logo, é preciso analisar, de modo profundo, as modalidades de dispensa de licitação utilizadas na realização da despesa, pois há indícios de erro no lançamento contábil. 
Foi constatado que, em nenhum momento, o Centro de Seleção e Promoção de Eventos/Centro Brasileiro de Pesquisa em Avaliação e Seleção e de Promoção de Eventos (CESPE/CEBRASPE) buscou fazer um processo licitatório para a locação de espaço físico, sendo que todas as contratações se deram por dispensa de licitação, variando as modalidades de compras direta por meio das exceções estabelecidas no art. 24 da Lei n. 8.666/1993 - o que pode acarretar em contratações com valores superior ao preço médio de mercado.

Assim, a licitação seria necessária para obter proposta mais vantajosa para administração e otimizar os custos dos contratos celebrados pelo CESPE/CEBRASPE. Ressalta-se que a própria Lei n. 8.666/1993, em seu art. 30, caput, tratou de conceituar o termo "licitação", in verbis:

\begin{abstract}
Art. $3^{\circ}$ A licitação destina-se a garantir a observância do princípio constitucional da isonomia e a selecionar a proposta mais vantajosa para a Administração e será processada e julgada em estrita conformidade com os princípios básicos da legalidade, da impessoalidade, da moralidade, da igualdade, da publicidade, da probidade administrativa, da vinculação ao instrumento convocatório, do julgamento objetivo e dos que lhes são correlatos. (Redação dada pela Lei n. 12.349, de 2010)
\end{abstract}

A partir dessa definição, Meirelles (2005, p. 269), destaca que a licitação tem dupla finalidade: "obtenção do contrato mais vantajoso e resguardo do direito de possíveis contratados".

Salienta-se que, sendo o CESPE/CEBRASPE uma Organização Social (OS) e por ser um ente público, deve seguir estritamente o que está estabelecido em Lei, pois, conforme Meireles (2001, p. 82), "o administrador não tem vontade própria e, por isso, só lhe é permitido fazer o que é autorizado em lei, ao contrário do que ocorre com o administrador particular, a quem é permitido fazer tudo o que a lei não 
proíba". Logo, para a Administração Pública, a Lei determina o que deve ser feito, já para o privado o que pode ser feito.

Portanto, é necessário que o CESPE/CEBRASPE descreva o modelo de espaço físico para realização dos eventos, haja vista que para qualquer modalidade de licitação, seja para aquisição de bens ou prestação de serviços, é imprescindível que haja a especificação do objeto a ser licitado, conforme já destacado na Súmula n. 177 do Tribunal de Contas da União (TCU).

Neste sentido, deve haver mais estudos quanto à forma de contratação dos espaços para realização de eventos públicos, buscando analisar as formas de contratações de outras bancas examinadoras públicas e privadas, para que se possa fazer um levantamento dos custos das contratações.

Segundo Mazzilli (2010, p. 4), em matéria de dinheiros públicos,

[...] quem gastar, tem que gastar de acordo com a lei" - o que corretamente anotou Batista Ramos ("Considerações sobre: parecer prévio, princípio da legalidade, competência para julgamento", em Revista do Tribunal de Contas da União 5(8):41-54)"

Também se tem a necessidade de um estudo mais aprofundado sobre a locação de espaço público, no sentido de identificar o porque da instituição pública quando locada, o recurso é repassado diretamente para a Secretaria de Educação dos Estados e Municípios, e como essas Secretarias estão tratando esses recursos recebidos com a locação de espaços físicos, pois não se sabe ao certo se esses recursos retornam para as instituições de ensino que cederam seus espaços.

Pesquisar se esses recursos retornam para instituição pública que cederam seus espaços e como eles foram gastos podem contribuir tanto para outros estudos que buscam identificar novas fontes de recursos para a educação como para 
vinculação desses recursos em determinantes da qualidade do ensino, como, por exemplo, investindo em infraestrutura.

Sugere-se ainda um estudo mais aprofundado sobre a forma como as instituições públicas que receberam recursos com a locação dos espaços estão gastando os valores, haja vista que a presente pesquisa ratifica a infraestrutura como uma determinante na qualidade do ensino. Logo, saber se os recursos estão sendo investidos na melhoria das instituições de ensino pode comprovar que a receita referente à locação do espaço físico pode influenciar na qualidade do ensino.

Por conseguinte, ainda são poucas as pesquisas que tratam da captação de recursos das instituições públicas, por meio de prestação de serviços ou de locação de espaço físico. Tais instituições públicas, principalmente aquelas de nível superior, devem buscar formas de aumentar suas receitas, haja vista que o repasse de recursos para estas encontram-se cada vez mais escassos e suas contas terminam fechando com déficit, o que pode comprometer a qualidade dos serviços prestados pelas mesmas.

De forma mais abrangente, por meio do Censo Escolar ofertado anualmente pelo Instituto Nacional de Estudos e Pesquisas Educacionais Anísio Teixeira (INEP), também pode ser realizados estudos sobre a disponibilidade de espaço público em todo o Brasil, pois, a presente pesquisa limitou-se à apresentar o espaço público disponível apenas do Distrito Federal. 


\section{REFERÊNCIAS}

AGLANTZAKIS, L. C. Breves conceitos sobre o instituto do concurso público no Direito brasileiro. Âmbito Jurídico, Rio Grande, v. VI, n. 15, nov. 2003. Disponível em: $<$ http://www.ambitojuridico.com.br/site/index.php?n_link=revista_artigos_leitura\&artigo_id=4092>.

Acesso em: 26 jan. 2015.

ALONSO, M. Custos no serviço público. Revista do Serviço Público, a. 50, n. 1, p. 37-63, jan./mar. 1999. Disponível em: $<$ http://www.bresserpereira.org.br/Documents/MARE/Terceiros-Papers/99-

Alonso50(1).pdf>. Acesso em: 26 jan. 2015.

ANTUNES, M. C. Maturidade do alinhamento estratégico entre o Plano Plurianual e os órgãos de controle: um estudo de caso no Ministério Público da União. 2011. Dissertação (Mestrado em Administração) - Faculdade e Economia, Administração, Contabilidade e Ciência da Informação e Documentação, Universidade de Brasília, Brasília, 2011. Disponível em: <http://repositorio.unb.br/bitstream/10482/9750/1/2011_MacielCarlosAntunes.pdf>. Acesso em: 26 jan. 2015.

ARENDT, H. A condição humana. Trad. de Roberto Raposo. Rio de Janeiro: Forense Universitária, 1983.

A condição humana. Trad. de Roberto Raposo. 10. ed. Rio de Janeiro: Forense Universitária, 2008.

ASCHER, F. Metapolis: acerca do futuro das cidades. Oeiras: Celta Editora, 1998. $240 \mathrm{p}$.

Augusto, C. A.; SOUZA, J. P.; DELlagnelo, E. H. L.; CARIO, S. A. F. Pesquisa Qualitativa: rigor metodológico no tratamento da teoria dos custos de transação em artigos apresentados nos congressos da Sober (2007-2011). RESR, Piracicaba, v. 51, n. 4, p. 745-764, out./dez. 2013. Disponível em: <http://www.scielo.br/pdf/resr/v51n4/a07v51n4.pdf>. Acesso em: 10 abr. 2016.

BANDEIRA de MELLO, C. A. Prestação de serviços públicos e administração indireta. São Paulo: Revista dos Tribunais, 1975.

BARBOSA, M. E. F.; BELTRÃO, K. I.; FARIÑAS, M. S.; FERNANDES, C.; SANTOS, D. Modelagem do SAEB - 99: modelos multiníveis. Relatório Técnico, Rio de Janeiro, INEP/MEC, 2001. 
; FERNANDES, C. A escola brasileira faz diferença? Uma investigação dos efeitos da escola na proficiência em matemática dos alunos da $4 a$ série. In: FRANCO, C. (Org.). Avaliação, ciclos e promoção na Educação. Porto Alegre: Artmed, 2001.

BLEGER, J. Temas de Psicologia: entrevista e grupos. Trad. de Rita Maria M. de Moraes. São Paulo: Martins Fontes, 1980.

BONI, V.; QUARESMA, S. J. Aprendendo a entrevistar: como fazer entrevistas em Ciências Sociais. Em Tese, v. 2, n. 1, p. 68-80, jan./jul. 2005. Disponível em: $<$ https://periodicos.ufsc.br/index.php/emtese/article/viewFile/18027/16976>. Acesso em: 07 mar. 2016.

BRAGA, M. V. A. Debruçando-se sobre a questão da qualidade do gasto público. Administradores, 05 de dezembro de 2012. Disponível em: $<$ http://www.administradores.com.br/artigos/economia-e-financas/debrucando-sesobre-a-questao-da-qualidade-do-gasto-publico/67687/>. Acesso em: 07 mar. 2016.

BRASIL. Constituição da República dos Estados Unidos do Brasil (de 24 de fevereiro de 1891). Rio de Janeiro, 1891. Disponível em: <http://www.planalto.gov.br/ccivil_03/Constituicao/Constituicao91.htm>. Acesso em: 26 jan. 2015.

Constituição da República dos Estados Unidos do Brasil (de 16 de julho
de 1934). Rio de Janeiro, 1934. Disponível em: < http://www.planalto.gov.br/ccivil_03/Constituicao/Constituicao34.htm>. Acesso em: 26 jan. 2015.

Constituição da Republica Federativa do Brasil de 1988. Brasília, 1988. Disponível em: <http://www.planalto.gov.br/ccivil_03/Constituicao/Constituicao.htm>. Acesso em: 26 jan. 2015.

. Constituição Politica do Imperio do Brazil (de 25 de março de 1824). Rio de Janeiro, $1824 . \quad$ Disponível em: <http://www.planalto.gov.br/ccivil_03/Constituicao/Constituica024.htm>. Acesso em: 26 jan. 2015.

. Controladoria-Geral da União. Portal da Transparência. Brasília, 2016. Disponível em: <http://www.portaldatransparencia.gov.br/>. Acesso em: 26 jan. 2016. 
Decreto n. 3.725, de 10 de janeiro de 2001. Regulamenta a Lei n. 9.636, de 15 de maio de 1998, que dispõe sobre a regularização, administração, aforamento e alienação de bens imóveis de domínio da União, e dá outras providências. $\quad$ Brasília, 2001. Disponível em: <http://www.planalto.gov.br/ccivil_03/decreto/2001/d3725.htm>. Acesso em: 26 jan. 2015.

. Lei n. 8.112, de 11 de dezembro de 1990. Dispõe sobre o regime jurídico dos servidores públicos civis da União, das autarquias e das fundações públicas federais. Brasília, 1990. Disponível em: <http://www.planalto.gov.br/ccivil_03/leis/L8112cons.htm>. Acesso em: 26 jan. 2015.

Lei n. 8.666, de 21 de junho de 1993. Regulamenta o art. 37, inciso XXI, da Constituição Federal, institui normas para licitações e contratos da Administração Pública e dá outras providências. Brasília, 1993. Disponível em: <http://www.planalto.gov.br/ccivil_03/leis/L8666cons.htm>. Acesso em: 26 jan. 2015.

. Lei n. 9.636, de 15 de maio de 1998. Dispõe sobre a regularização, administração, aforamento e alienação de bens imóveis de domínio da União, altera dispositivos dos Decretos-Leis ns. 9.760, de 05 de setembro de 1946, e 2.398, de 21 de dezembro de 1987, regulamenta o $\S 2^{\circ}$ do art. 49 do Ato das Disposições Constitucionais Transitórias, e dá outras providências. Brasília, 1998. Disponível em: <http://www.planalto.gov.br/ccivil_03/leis/L9636.htm>. Acesso em: 26 jan. 2015.

Lei n. 9.637, de 15 de maio de 1998. Dispõe sobre a qualificação de entidades como organizações sociais, a criação do Programa Nacional de Publicização, a extinção dos órgãos e entidades que menciona e a absorção de suas atividades por organizações sociais, e dá outras providências. Brasília, 1998. Disponível em: <http://www.planalto.gov.br/ccivil_03/leis/L9637.htm>. Acesso em: 26 jan. 2015.

Lei n. 12.527, de 18 de novembro de 2011. Regula o acesso a informações previsto no inciso XXXIII do art. $5^{\circ}$, no inciso II do $\S 3^{\circ}$ do art. $37 \mathrm{e}$ no $\S 2^{\circ}$ do art. 216 da Constituição Federal; altera a Lei n. 8.112, de 11 de dezembro de 1990; revoga a Lei n. 11.111, de 5 de maio de 2005, e dispositivos da Lei n. 8.159, de 8 de janeiro de 1991; e dá outras providências. Brasília, 2011. Disponível em: <http://www.planalto.gov.br/ccivil_03/_ato20112014/2011/lei/l12527.htm>. Acesso em: 26 jan. 2015.

Lei Complementar n. 101, de 04 de maio de 2000. Estabelece normas de finanças públicas voltadas para a responsabilidade na gestão fiscal e dá outras providências. Brasília, 2000. Disponível em: <http://www.planalto.gov.br/ccivil_03/leis/LCP/Lcp101.htm>. Acesso em: 06 out. 2014. 
. Ministério da Educação. Secretaria de Educação Profissional e Tecnológica. Instituto Federal de Educação, Ciência e Tecnologia de Brasília. Plano de Desenvolvimento Institucional 2014-2018: vigência no e-MEC (Recredenciamento da IES): junho/2014 a junho/2019. Brasília, abr. 2014. Disponível em: <http://www.ifb.edu.br/attachments/article/3933/Plano_de_Desenvolvimento_Instituci onal_2014_2018_IFB.pdf>. Acesso em: 17 mar. 2016.

. Ministério da Fazenda. Receita Federal. Emissão de Comprovante de Inscrição e de Situação Cadastral. 2016. Disponível em: $<$ http://www.receita.fazenda.gov.br/pessoajuridica/cnpj/cnpjreva/cnpjreva_solicitacao .asp>. Acesso em: 04 jan. 2016.

Ministério do Planejamento, Orçamento e Gestão. Boletim Estatístico de Pessoal. Brasília, 19 de junho de 2015. Disponível em: $<$ http://www.planejamento.gov.br/assuntos/gestao-publica/arquivos-epublicacoes/BEP>. Acesso em: 20 maio 2015.

Tribunal de Contas da União. Acórdão n. 79/2000. Tomada de Contas Especial. Royalties. Prefeitura Municipal de Teofilândia BA. Recurso de reconsideração contra acórdão que julgou as contas irregulares e em débito o responsável ante a omissão na prestação de contas. Inconsistências em documentos apresentados. Conhecimento. Negado provimento. Brasília, 2000. Disponível em: <http://www.lexml.gov.br/urn/urn:lex:br:tribunal.contas.uniao;camara.1:acordao:200003-14;79>. Acesso em: 26 jan. 2015.

. Tribunal de Contas da União. Acórdão n. 73/2003. Tomada de Contas. Secretaria de Administração do Ministério Público Federal - MPF/MPU. Exercício de 1999. Desvio de recursos da folha de pagamento praticadas por ex-servidora. Fatos já apreciados em processo de TCE, no qual foi imputado débito e cominada multa à responsável pelo Setor. Falhas em licitações e contratos. Contas irregulares da ex-servidora. Contas regulares com ressalva e quitação dos demais responsáveis. Determinação. Brasília, 2003. Disponível em: <http://www.lexml.gov.br/urn/urn:lex:br:tribunal.contas.uniao;camara.2:acordao:200302-06;73>. Acesso em: 26 jan. 2015. 
Tribunal de Contas da União. Acórdão n. 569/2005. Representação formulada por unidade técnica do TCU. Possíveis irregularidades praticadas no âmbito da Comissão Nacional de Energia Nuclear - CNEN. Dispensa de licitação na contratação da Fundação de Apoio, Pesquisa e Extensão do Centro de Ciências Matemáticas e da Natureza da Universidade Federal do Rio de Janeiro - FCCMN/UFRJ, pessoa jurídica de direito privado, sem fins lucrativos, para execução de concurso público. Acolhimento das razões de justificativa apresentadas pelo responsável. Conhecimento. Determinação. Juntada dos autos às contas anuais. Relator: Min. Augusto Sherman. Brasília, $2005 . \quad$ Disponível em: <http://www.lexml.gov.br/urn/urn:lex:br:tribunal.contas.uniao;plenario:acordao:200505-11;569>. Acesso em: 26 jan. 2015.

Tribunal de Contas da União. Acórdão n. 831/2013. Consulta. Dúvidas suscitadas na aplicação de normas sobre procedimentos exigidos tanto em relação às receitas decorrentes da arrecadação de taxa de inscrição em concurso público, quanto no tocante às despesas necessárias à sua realização. Conhecimento. Resposta à autoridade consulente. Arquivamento dos autos. Brasília, 2013. Relator: Min. Valmir Campelo. Disponível em: <http://www.lexml.gov.br/urn/urn:lex:br:tribunal.contas.uniao;plenario:acordao:201304-10;831>. Acesso em: 26 jan. 2015.

Tribunal de Contas da União. Acórdão n. 1.512/2004. Representação formulada por unidade técnica do TCU. Possíveis irregularidades praticadas pelo CADE. Notícias veiculadas pela imprensa. Aluguel de imóvel, sem licitação, por preço superior ao de mercado. Contrato sem orçamento detalhado. Inexigibilidade de licitação para realização de serviço de instalação e desinstalação de central telefônica. Pagamento antecipado. Conhecimento. Procedência parcial. Acolhimento das justificativas de um dos responsáveis. Rejeição das de outros. Multa. Conversão dos autos em TCE. Determinação. Juntada dos autos às contas anuais. Remessa de cópia ao MPU e à $4^{\mathrm{a}}$ Vara da Seção Judiciária do DF - TRF $1^{a}$ Região. Relator: Min. Augusto Sherman. Brasília, 2004. Disponível em: $<$ http://www.lexml.gov.br/urn/urn:lex:br:tribunal.contas.uniao;plenario:acordao:200409-29;1512>. Acesso em: 26 jan. 2015.

Tribunal de Contas da União. Acórdão n. 2.582/2005. Relatório de Auditoria. Relator: Min. Augusto Nardes. Brasília, 2005. Disponível em: $<$ https://contas.tcu.gov.br/juris/Web/Juris/ConsultarTextual2/Jurisprudencia.faces?col egiado=PRIMEIRA+CAMARA\&numeroAcordao=2582\&anoAcordao=2005>. Acesso em: 26 jan. 2015.

Tribunal de Contas da União. Súmula n. 177, de 29 de outubro de 1982. Brasília, 1982. Disponível em: <https://contas.tcu.gov.br/juris/SvlHighLight>. Acesso em: 14 mar. 2016. 
. Revista Licitações e Contratos - Orientações e Jurisprudência do TCU.

4. ed. Brasília: Senado Federal, 2010.

CAMPOS, J. CESPE/CEBRASPE: A história da maior central de concursos do Brasil. Secom UnB, 16 de fevereiro de 2011. Disponível em: <http://www.unb.br/noticias/unbagencia/unbagencia. php?id=4632>. Acesso em 04 maio 2015.

CARVALHO, M. S. M. V.; TONET, H. C. Qualidade na Administração Pública. Revista de Administração Pública, Rio de Janeiro, v. 28, n. 2, p. 137-152, abr./jun. 1994. Disponível em: <http://bibliotecadigital.fgv.br/ojs/index.php/rap/article/view/8481/7224>. Acesso em: 02 nov. 2015.

CERVO, A. L.; BERVIAN, P. A.; SILVA, R. Metodologia científica. 6. ed. São Paulo: Pearson Prentice Hall, 2007.

CONCURSOS NO BRASIL. Organizadoras de Concursos. 2015. Disponível em: $<$ http://www.concursosnobrasil.com.br/concursos/organizadoras/>. Acesso em: 26 jan. 2015.

DEMO, P. Metodologia de conhecimento cientifico. 1. ed. 11. reimpr. São Paulo: Atlas, 2013.

DI PIETRO, M. S. Z. Direito Administrativo. 19. ed. São Paulo: Atlas, 2006.

DIAS. T. R. S.; OMOTE, S. Entrevista em Educação Especial: aspectos metodológicos. Revista Brasileira de Educação Especial, Piracicaba, v. 3, p. 93100, $1995 . \quad$ Disponível em: <http://www.abpee.net/homepageabpee04_06/artigos_em_pdf/revista3numero1pdf/r 3_art08.pdf>. Acesso em: 28 mar. 2016.

DISTRITO FEDERAL. Lei n. 4.949, de 15 de outubro de 2012. Estabelece normas gerais para realização de concurso público pela administração direta, autárquica e fundacional do Distrito Federal. Brasília, 2012. Disponível em: <http://www.lexml.gov.br/urn/urn:lex:br;distrito.federal:distrital:lei:2012-10-15;4949>. Acesso em: 26 jan. 2015. 
- Secretaria de Estado de Educação. Subsecretaria de Planejamento, Acompanhamento e Avaliação Educacional. Coordenação de Supervisão Institucional e Normas de Ensino. Gerência de Documentação e Acervo Escolar. Relação de instituições educacionais credenciadas no Distrito Federal. Brasília, 2013.

$<$ http://www.cre.se.df.gov.br/ascom/documentos/linkpag/inst_credenciadas_ago13.p df>. Acesso em: 13 fev. 2015.

Secretaria de Estado de Educação. Subsecretaria de Planejamento, Acompanhamento e Avaliação Educacional. Coordenação de Informações Educacionais. Turmas e matrículas: total de turmas e matrículas por etapa/modalidade de ensino em 13/04/2015 - Total por instituição educacional. Brasília, 2015.2 Disponível em: <http://www.cre.se.df.gov.br/ascom/documentos/suplav/turmas_e_matriculas_por_es colas_2015_final.pdf>. Acesso em: 26 jan. 2015.

DUARTE, R. Entrevistas em pesquisas qualitativas. Educar, Curitiba, n. 24, p. 213225, 2004. Disponível em: <http://www.scielo.br/pdf/er/n24/n24a11.pdf>. Acesso em: 29 mar. 2016.

FALCO, J. G. Estatística aplicada. Cuiabá: EdUFMT; Curitiba: UFPR, 2008. 2006

Vade-Mecum de Licitações e Contratos. 3. ed. Belo Horizonte: Fórum,

FERRÃO, M. E.; BELTRÃO, K. I.; FERNANDES, C.; SANTOS, D.; SUAREZ, M.; ANDRADE, A. C. O SAEB - Sistema Nacional de Avaliação da Educação Básica: objetivos, características e contribuições na investigação da escola eficaz. Revista Brasileira de Estudos de População, v. 18, n. 1/2, p. 111-130, jan./dez. 2001. Disponível em: <http://www.abep.nepo.unicamp.br/docs/rev_inf/vol18_n1e2_2001/vol18_n1e2_2001 _7artigo_111_130.pdf>. Acesso em: 13 abr. 2015.

FONSECA, J. S.; MARTINS, G. A. Curso de Estatística. 6. ed. São Paulo: Atlas, 1996. 
FONTAINHA, F. C.; GERALDO, P. H. B.; VERONESE, A.; ALVES, C. S.; FIGUEIREDO, B. H.; WALDBURGER, J. Processos seletivos para a contratação de servidores públicos: Brasil, o país dos concursos? Rio de Janeiro: FGV Direito Rio, 2014. 184 p. (Novas ideias em Direito). Disponível em: <http://bibliotecadigital.fgv.br/dspace/bitstream/handle/10438/11929/Processos\%20s eletivos\%20para\%20a\%20contrata\%C3\%A7\%C3\%A3o\%20de\%20servidores\%20p $\%$ C3\%BAblicos\%20$\% 20$ Brasil, $\% 200 \% 20$ pa\%C3\%ADs $\% 20$ dos $\% 20$ concursos.pdf?sequence=1>. Acesso em: 06 out. 2013.

FRANCO, H. Auditoria contábil. 4. ed. 6. reimpr. São Paulo: Atlas, 2009.

GIL, A. C. Como elaborar projetos de pesquisa. 5. ed. São Paulo: Atlas, 2010. Métodos e técnicas de pesquisa social. 5. ed. São Paulo: Atlas, 1999. 202 p.

HAGUETTE, T. M. F. Metodologias qualitativas na Sociologia. 5. ed. Petrópolis, RJ: Vozes, 1997.

HIRANO, S. (Org.). Pesquisa social: projeto e planejamento. São Paulo: T. A. Queiroz, 1979.

HOOD, C. A public management for all seasons? Public Administration, v. 69, n. 1, p. 3-19, mar. 1991. Disponível em: <http://onlinelibrary.wiley.com/doi/10.1111/j.14679299.1991.tb00779.x/pdf>. Acesso em: 26 jan. 2015.

INSTITUTO BRASILEIRO DE GEOGRAFIA E ESTATÍSTICA - IBGE. Estimativas populacionais para os municípios brasileiros em 01.07.2014. 2014a. Disponível em:

<http://www.ibge.gov.br/home/estatistica/populacao/estimativa2014/estimativa_dou.s htm>. Acesso em: 28 mar. 2016.

Perfil dos Estados e dos Municípios Brasileiros 2014. 2014b. Disponível em: <http://www.ibge.gov.br/home/estatistica/economia/perfilmunic/2014/>. Acesso em: 28 mar. 2016.

INSTITUTO NACIONAL DE ESTUDOS E PESQUISAS EDUCACIONAIS ANÍSIO TEIXEIRA - INEP. Censo Escolar 2013. Brasília, 2013. Disponível em: <http://portal.inep.gov.br/basica-censo>. Acesso em: 20 maio 2015. 
Censo Escolar 2014. Brasília, 2014. Disponível em: $\overline{<h t t p: / / p o r t a l . i n e p . g o v . b r / b a s i c a-c e n s o>. ~ A c e s s o ~ e m: ~} 20$ maio 2015.

IUDíCIBUS, S.; MARTINS, E.; GELBCKE, E. R. Manual de Contabilidade das sociedades por ações. 4. ed. São Paulo: Atlas, 1995.

JUSTEN FILHO, M. Comentários à lei de licitações e contratos administrativos. 12. ed. São Paulo: Dialética, 2008.

. Comentários à lei de licitações e contratos administrativos. 13. ed. São Paulo: Dialética. 2009. 943 p.

KAUARK, F.; MANHÃES, F. C.; MEDEIROS, C. H. Metodologia da pesquisa: guia prático. Itabuna, BA: Via Litterarum, 2010.

KERLINGER, F. N. Metodologia da pesquisa em Ciências Sociais: um tratamento conceitual. São Paulo: EPU: Edusp, 1980.

LIMA, A.; LIMA FILHO, R. C. O papel do CESPE/UnB na sociedade: processos de prestação de serviços. 2008. Trabalho de Conclusão de Curso (Especialização em Gestão Universitária) - Faculdade de Economia, Administração, Contabilidade e Ciência da Informação e Documentação, Universidade de Brasília, Brasília, 2008. Disponível em: <http://bdm.unb.br/bitstream/10483/1243/1/2008_AngelaLima_RaimundoLimaFilho.p df>. Acesso em: 12 jan. 2015.

MANZINI, E. J. A entrevista na pesquisa social. Didática, São Paulo, v. 26/27, p. 149-158, 1990/1991.

MATOS, F. L. Espaços públicos e qualidade de vida nas cidades - $O$ caso da cidade do Porto. Observatorium: Revista Eletrônica de Geografia, v. 2, n. 4, p. 17-33, jul. $2010 . \quad$ Disponível em: <https://sigarra.up.pt/flup/pt/pub_geral.show_file?pi_gdoc_id=444783>. Acesso em: 26 jan. 2015.

MAZZILLI, H. N. Concurso público na Administração. Revista dos Tribunais, 2010. Disponível em: <http://www.mazzilli.com.br/pages/artigos/concadmin.pdf>. Acesso em: 14 mar. 2016.

MEIRELLES, H. L. Direito Administrativo brasileiro. São Paulo: Malheiros, 2001. 
Direito Municipal brasileiro. 15. ed. São Paulo: Malheiros, 2007.

2005.

Licitação e contrato administrativo. 30 ed. São Paulo: Malheiros Editores,

MINAYO, M. C. S.; SANCHES, O quantitativo-qualitativo: oposição ou complementariedade? Cad. Saúde Públ., Rio de Janeiro, v. 9, n. 3, p. 239-262, jul./set., 1993. Disponível em: <http://www.scielo.br/pdf/csp/v9n3/02>. Acesso em: 10 abr. 2016.

MONEY, A.; BABIN, B.; HAIR JUNIOR, J. F.; SAMOUEL, P. Fundamentos de métodos de pesquisa em Administração. Trad. de Lene Belon Ribeiro. Porto Alegre: Bookman, 2005. 472 p.

MORAES, A. Direito Constitucional. 23. ed. São Paulo: Atlas, 2008.

MORAIS, A. C. A busca da prova pericial contábil. Brasília: A. C. Morais, 2005.

MOTTA, A. R. O combate ao desperdício no gasto público: uma reflexão baseada na comparação entre os sistemas de compras privado, publico federal norteamericano e brasileiro. 2010. Dissertação (Mestrado em Desenvolvimento Econômico) - Instituto de Economia, Universidade Estadual de Campinas, Campinas, SP, 2010. Disponível em: <http://www.recursoshumanos.sp.gov.br/Arquivos/Promocao/Biblioteca/Disserta\%C3 \%A7\%C3\%A3o_Alexandre\%20Ribeiro\%20Motta_Unicamp_Versao\%20Final.pdf>. Acesso em: 02 mar. 2016.

NEVES, J. L. Pesquisa qualitativa - Características, usos e possibilidade. Caderno de Pesquisas em Administração, São Paulo, v. 1, n. 3, 1996. Disponível em: $<$ http://www.unisc.br/portal/upload/com_arquivo/pesquisa_qualitativa_caracteristicas _usos_e_possibilidades.pdf>. Acesso em: 28 mar. 2016.

NEVES, M. J.; LIMA, D. H. C. Ocupação por terceiros de espaço físico em bens imóveis de órgãos públicos. Revista Jus Navigandi, Teresina, a. 13, n. 1.784, maio 2008. Disponível em: <http://jus.com.br/artigos/11283>. Acesso em: 05 out. 2015.

OLIVEIRA, S. L. Tratado de metodologia científica: projetos de pesquisas, TGI, TCC, monografias, dissertações e teses. 2.ed. São Paulo: Pioneira Thomson Learning, 2001. 320 p. 
PASSADOR, C. S.; YOSHIMOSHI, G. T. B.; ARTONI, C. B. Fatores associados ao desempenho do aluno: uma análise através de modelos hierárquicos aplicados nos dados das oitavas séries do ensino público do Estado de São Paulo. In: 25 Simpósio Brasileiro e $2^{\circ}$ Congresso Ibero-Americano de Política e Administração da Educação, São Paulo, 2011.

PATI, C. O estilo das 6 principais bancas de concursos públicos. In: Revista Exame, 29 de agosto de 2013. Disponível em: <http://exame.abril.com.br/carreira/noticias/oestilo-das-6-principais-bancas-de-concursos-publicos>. Acesso em: 14 mar. 2016.

PEARSON divulga novo índice global de educação e mostra que superpotências asiáticas se destacam em termos educacionais. In: Maxpress, 08 de maio de 2014. Disponível em: <http://www.maxpressnet.com.br/Conteudo/1,671658,Pearson_divulga_novo_indice _global_de_educacao_e_mostra_que_superpotencias_asiaticas_se_destacam_em_ termos_educacionais, $\overline{6} 7 \overline{16} 658,8 . \overline{h t m}>$. Acesso em: 26 jan. 2015.

PINTO, E. L.; COSTA, B. L. C. A distinção entre público e privado e sua caracterização no âmbito do estado brasileiro. Revista Digital de Direito Administrativo, v. 2, n. 1, p. 311-323, 2015. Disponível em: <http://www.revistas.usp.br/rdda/article/view/84744/92164>. Acesso em: 26 jan. 2015.

PIRES, V. Gestão orçamentária e qualidade do gasto público. Araraquara, SP. jul. $2008 . \quad$ Disponível em: <https://professorpires.files.wordpress.com/2012/09/gestorcgastopublbiz.pdf>. Acesso em: 02 mar. 2016.

PORTAL DE CONTABILIDADE. NBC T 13 - Da perícia contábil. 2016. Disponível em: <http://www.portaldecontabilidade.com.br/nbc/t13.htm>. Acesso em: 26 jan. 2015.

QUEIROGA, F. Seleção de pessoas e desempenho no trabalho: um estudo sobre a validade preditiva dos testes de conhecimentos. 2009. Tese (Doutorado em Psicologia Social, do Trabalho e das Organizações) - Programa de PósGraduação em Psicologia Social, do Trabalho e das Organizações, Departamento de Psicologia Social e do Trabalho, Instituto de Psicologia, Universidade de Brasília, Brasília, 2009. Disponível em: <http://repositorio.unb.br/bitstream/10482/8437/1/2009_FabianaQueiroga.pdf>. Acesso em: 28 mar. 2016.

QUIVY, R.; CAMPENHOUDT, L. V. Manual de investigação em Ciências Sociais. 3. ed. Lisboa: Gradiva. 2003. 
RIGOLIN, I. B. Cooperativas em licitações podem participar. Boletim de Licitações e Contratos, São Paulo, NDJ, n. 1, p. 25-27, jan. 2002.

. Notória especialização - Natureza singular - Contratos simultâneos. Boletim de Licitações e Contratos, São Paulo, v. 7, n. 7, p. 328-334, jul. 1994.

SECCHI, L. Modelos organizacionais e reformas da Administração Pública. Revista de Administração Pública, Rio de Janeiro, v. 43, n. 2, p. 347-369, mar./abr., 2009. Disponível em: <http://www.scielo.br/pdf/rap/v43n2/v43n2a04.pdf>. Acesso em: 28 mar. 2016.

SILVA FILHO, A. M. Educação: fator determinante de desenvolvimento. Revista Espaço Acadêmico, a. 7, n. 84, 2008. Disponível em: <http://www.espacoacademico.com.br/084/84amsf.htm>. Acesso em: 12 jan. 2015.

SILVESTRE, A. L. Análise de dados e estatística descritiva. Lisboa: Escolar Editora, 2007.

SOARES, J. F. O efeito da escola no desempenho cognitivo de seus alunos. REICE - Revista Electrónica Iberoamericana sobre Calidad, Eficacia y Cambio en Educación, v. 2, n. 2, p. 1-17, 2004. Disponível em: <http://www.ice.deusto.es/RINACE/reice/vol2n2/Soares.pdf>. Acesso em: 26 jan. 2015.

; CÉSAR, C. C.; MAMBRINI, J. Determinantes de desempenho dos alunos do ensino básico brasileiro: evidências do SAEB de 1997. In: FRANCO, C. (Org.). Avaliação, ciclos e promoção na Educação. Porto Alegre: Artmed, 2001.

; KARINO, C. A.; JESUS, G. R.; ANDRADE, D. F. A infraestrutura das escolas públicas brasileiras de pequeno porte. Revista do Serviço Público, Brasília, v. 64, n. 3, p. 377-391, jul/set. 2013b. Disponível em: <http://seer.enap.gov.br/index.php/RSP/article/view/129/129>. Acesso em: 26 jan. 2015.

STEVENSON, W. J. Estatística aplicada à administração. São Paulo: Harper \& Row do Brasil, 1981.

TRIVIÑOS, A. N. S. Introdução à pesquisa em Ciências Sociais: a pesquisa qualitativa em educação. São Paulo: Atlas, 1987. 
UNIVERSIDADE DE BRASÍLIA - UnB. Novo Anuário Estatístico da UnB 2015: período 2010-2014. Brasília, 2015a. Disponível em: <http://www.dpo.unb.br/documentos/anuario/Anuario_Estatistico_2015_Parcial.pdf>. Acesso em: 17 mar. 2016.

Plano de Desenvolvimento Institucional 2014-2017. Brasília, 2014. Disponível em: <http://www.unb.br/noticias/downloads/PDI.2014-2017.pdf>. Acesso em: 17 mar. 2016.

Decanato de Planejamento e Orçamento. Prestação de Contas Ordinária Anual: Relatório de Gestão do Exercício de 2010. Brasília, 2011. Disponível em: <http://www.unb.br/contasanuais/downloads/Relatorio_de_Gestao_2010.pdf>. Acesso em: 26 jan. 2015.

. Decanato de Planejamento e Orçamento. Relatório de Gestão do Exercício de 2014. Brasília, 2015b. Disponível em: <http://www.unb.br/contasanuais/downloads/Relatorio_de_Gestao_2010.pdf>. Acesso em: 26 jan. 2015.

VEIGA, C. A. Direito financeiro e aplicado: planejamento, elaboração, execução e controle orçamentário. São Paulo: Revista dos Tribunais, 1975.

VERGARA, S. C. Métodos de pesquisa em Administração. São Paulo: Atlas, 2005.

WIKIPÉDIA. Concurso público. 2015. Disponível em: <https://pt.wikipedia.org/wiki/Concurso_p\%C3\%BAblico>. Acesso em: 20 maio 2015.

Índice de Desenvolvimento Humano. 2015. Disponível em: <https://pt.wikipedia.org/wiki/\%C3\%8Dndice_de_Desenvolvimento_Humano>. Acesso em: 14 jan. 2015.

\section{Bibliografia consultada:}

ALYRIO, R. D. Métodos e técnicas de pesquisa em Administração. Rio de Janeiro: Fundação CECIERJ, 2009. 
ANDRADE, J. M.; LAROS, J. A. Fatores associados ao desempenho escolar: um estudo multinível com dados do SAEB/2001. Psicologia: Teoria e Pesquisa, v. 23, n. 1 , p. 33-42, jan./mar. 2007. Disponível em: <http://www.scielo.br/pdf/ptp/v23n1/a05v23n1.pdf>. Acesso em: 26 jan. 2015.

ANDRADE, N. A. Contabilidade Pública na gestão municipal: novos métodos após a LC 101/00 e as classificações contábeis advindas da SOF e STN. São Paulo: Atlas, 2002.

ARAÚJO, I. P. S.; ARRUDA, D. G. Contabilidade pública: da teoria à prática. São Paulo: Saraiva, 2004.

ARAÚJO NETO, W. C. Da não aplicabilidade das regras do concurso público aos serviços sociais autônomos, e natureza jurídica das receitas fomentadoras destas entidades privadas. 2013. 17 f. Artigo (Especialização) - Instituto Brasiliense de Direito Público, Brasília, 2013. Disponível em: <http://dspace.idp.edu.br:8080/xmlui/bitstream/handle/123456789/1484/Artigo_Wilso n\%20Corr\%C3\%AAa\%20de\%20Ara\%C3\%BAjo\%20Neto.pdf?sequence=1>. Acesso em: 26 jan. $/ 2015$.

ARENDT, H. Homens em tempos sombrios. Trad. de Denise Bottmann. São Paulo: Companhia das Letras, 1987.

BRASIL. Lei n. 8.987, de 13 de fevereiro de 1995. Dispõe sobre o regime de concessão e permissão da prestação de serviços públicos previsto no art. 175 da Constituição Federal, e dá outras providências. Brasília, 1995. Disponível em: <http://www.planalto.gov.br/ccivil_03/leis/L8987compilada.htm>. Acesso em: 06 out. 2013.

Lei n. 9.074, de 07 de julho de 1995. Estabelece normas para outorga e prorrogações das concessões e permissões de serviços públicos e dá outras providências. Brasília, 1995.1 Disponível em: <http://www.planalto.gov.br/ccivil_03/leis/L9074cons.htm>. Acesso em: 06 out. 2014.

BRUNET, J. F. G.; BERTÊ, A. M. A.; BORGES, C. B. Qualidade do Gasto Público em Educação nas Redes Públicas Estaduais e Municipais. In: II Congresso CONSAD de Gestão Pública - Painel 32: Qualidade do gasto público II, 2008. Disponível em: <http://www.escoladegoverno.pr.gov.br/arquivos/File/Material_\%20CONSAD/paineis _II_congresso_consad/painel_32/qualidade_do_gasto_publico_em_educacao_nas_r edes_publicas_estaduais_e_municipais.pdf>. Acesso em: 26 jan. 2015. 
CARVALHO FILHO, J. S. Manual de Direito Administrativo. 21. ed. Rio de Janeiro: Lumen Juris, 2009.

CAVALCANTE, $P$. Descentralização de políticas públicas sob a ótica neoinstitucional: uma revisão de literatura. Revista de Administração Pública, Rio de Janeiro, v. 45, n. 6, p. 1781-1804, nov./dez. 2011. Disponível em: <http://www.scielo.br/pdf/rap/v45n6/a08v45n6.pdf>. Acesso em: 26 jan. 2015.

FAORO, R. Os donos do poder no Brasil: formação do patronato político brasileiro. São Paulo: Globo, 2001.

FERNANDES, J. U. J. Contratação direta sem licitação: modalidades, dispensa e inexibilidade de licitação. 5. ed. Brasília: Brasília Jurídica. 2000.

FLETCHER, P. R. À procura do ensino eficaz. Brasília: MEC, 1998.

FRAGIOLLI, W. L. A Administração Pública e sua contratação direta. JusBrasil, 2014. Disponível em: <http://fragiolli.jusbrasil.com.br/artigos/111681151/aadministracao-publica-e-sua-contratacao-direta>.

GIL, A. C. Como elaborar projetos de pesquisa. 3. ed. São Paulo: Atlas, 1996.

JUSTEN FILHO, Marcal. Comentários à Lei de Licitações e Contratos Administrativos. 10. ed. São Paulo: Dialética, 2004.

LEE, V. L. Utilização de modelos lineares hierárquicos lineares para estudar contextos sociais: o caso dos efeitos da escola. In: BROOKE, N.; SOARES, J. F. (Ed.). Pesquisa em eficácia escolar: origem e trajetórias. Belo Horizonte: Editora UFMG, 2008.

MACHADO JUNIOR, J. T.; REIS, H. C. Lei Federal n. 4.320/64 comentada. 30. ed. Rio de Janeiro: IBAM, 1997.

MENEZES-FILHO, N. Os determinantes do desempenho escolar no Brasil. Instituto Futuro Brasil, Ibmec-SP e FEA-SP. 2007. Disponível em: <http://www.cepe.ecn.br/seminarioiv/download/menezes_filho.pdf>. Acesso em: 13 abr. 2015. 
MIYAMOTO, Y. M. H.; KROHLING, Aloísio. Cidadania no Estado Democrático de Direito brasileiro sob a perspectiva de gênero. In: XXI Congresso Nacional do CONPEDI, 2012 Disponível em: <http://www.publicadireito.com.br/artigos/?cod=af8d1eb220186400>. Acesso em: 05 out. 2015.

REIS, E. Estatística descritiva. 7. ed. Lisboa: Silabo, 2008.

RICHARD, I. Má qualidade da educação prejudica competitividade, diz estudo da CNI. In: Agência Brasil, 14 de janeiro de 2015. Disponível em: <http://agenciabrasil.ebc.com.br/geral/noticia/2015-01/estudo-da-cni-diz-que-maqualidade-da-educacao-prejudica-trabalhador>. Acesso em: 14 jan. 2015.

SANTOS, S. V. A relação entre o público e o privado: um estudo inicial no pensamento de Hannah Arendt. Inter-Ação: Revista da Faculdade de Educação da UFG, Goiânia, v. 37, n. 2, p. 223-235, 2012. Disponível em: $<$ http://revistas.ufg.emnuvens.com.br/interacao/article/view/20717/12421>. Acesso em: 05 out. 2015.

SOARES, J. F. ANDRADE, R. J. Nível socioeconômico, qualidade e equidade das escolas de Belo Horizonte. Ensaio: Avaliação Política Pública Educacional, Rio de Janeiro, v. 14, n. 50, p. 107-126, jan./mar. 2006. Disponível em: <http://www.scielo.br/pdf/ensaio/v14n50/30410>. Acesso em: 26 jan. 2015.

SOARES, S. Por que investir em educação?: cinco motivos para o Brasil destinar mais recursos e esforços a essa área. In: Educar para Crescer, 12 de setembro de 2008. Disponível em: <http://educarparacrescer.abril.com.br/politica-publica/por-queinvestir-346136.shtml>. Acesso em: 14 jan. 2015.

SOUSA, A. R. O processo administrativo do concurso público. 2011. $160 \mathrm{f}$. Dissertação (Mestrado em Direito) - Universidade Federal de Uberlândia, Uberlândia, MG, 2011. Disponível em: $<$ http://repositorio.ufu.br/bitstream/123456789/1757/1/ProcessoAdministrativoConcur so.pdf>. Acesso em: 12 jan. 2015.

SOUZA, P. V. N. C. S. O ingresso no serviço público: condição e exceções à regra. Evocati Revista, Brasília, n. 71, nov. 2011. Disponível em: $<$ http://www.evocati.com.br/evocati/interna.wsp?tmp_page=interna\&tmp_codigo=501 \&tmp_secao=10\&tmp_topico=direitoconst\&wi.redirect=9EROBM22D4K3N2PRAWIB >. Acesso em: 22 dez. 2014.

VERGARA, S. C. Projetos e relatórios de pesquisa em Administração. 2. ed. São Paulo: Atlas, 1998. 
Sugestão para estruturação de um projeto de pesquisa. Cadernos de Pesquisa EBAP, Rio de Janeiro, n. 2, 1991. Disponível em: $<$ https://bibliotecadigital.fgv.br/dspace/bitstream/handle/10438/13030/000056762.pdf ?sequence=1\&isAllowed=y>. Acesso em: 26 jan. 2015. 


\section{ANEXOS}




\section{ANEXO "A" - ESTATUTO DO CEBRASPE}

\section{ESTATUTO DO CEBRASPE}

Capitulo I

\section{DAS CARACTERISTICAS E DA NATUREZA DA ENTIDADE}

Art. $10^{\circ} \mathrm{O}$ Centro Brasileiro de Pesquisa em Avaliação e Seleção e de Promoção de Eventos - CEBRASPE é pessoa jurídica de direito privado na forma de associação civil, sem fins lucrativos, com sede e foro em Brasília/DF, na Universidade de Brasilia (UnB), Campus Universitário Darcy Ribeiro, gleba A, Edifício Sede CespeUnB, Asa Norte, CEP 70904-970, qualificado como organização social por meio do Decreto $n^{\circ}$ 8078 , de 19 de agosto de 2013, e regido pelo presente Estatuto, pela Lei $n^{\circ} 9.637 / 98$, e subsidiariamente pelo Código Civil, bem como pela legislação que Ihe seja aplicável e pelo seu Regimento Interno e regulamentos próprios que tratam dos procedimentos para contratação de obras, serviços, compras e alienações e do plano de cargos, salários e benefícios dos empregados da entidade.

Art. $2^{\circ} \mathrm{O}$ prazo de duração do CEBRASPE é por tempo indeterminado.

Art. $3 .^{\circ}$ O CEBRASPE poderá atuar em qualquer parte do território nacional ou no exterior.

Parágrafo Único. Mediante aprovação do Conselho de Administração poderâo ser criados, para o efetivo cumprimento dos objetivos do CEBRASPE, núcleos de representação, filiais ou escritórios fora da sede, os quais funcionarão mediante delegação expressa da matriz e reger-se-ão pelos dispositivos deste Estatuto e do Regimento Interno.

Art. $4 .^{\circ}$ O CEBRASPE terá um Regimento Interno que, aprovado pelo Conselho de Administração, disciplinará a sua organização e funcionamento.

Parágrafo Único. O Regimento Interno e os regulamentos próprios, entre os quais o relativo aos procedimentos para a contratação de obras e serviços, compras e alienações, serão propostos pela Diretoria do CEBRASPE e aprovados pelo Conselho de Administração.

\section{Capitulo II}

\section{DA FINALIDADE E DOS OBJETIVOS}

Art. $5 .^{\circ} \mathrm{O}$ CEBRASPE tem por finalidade precipua fomentar e promover 0 ensino, a pesquisa cientifica, o desenvolvimento tecnológico e o desenvolvimento institucional, por meio dos seguintes objetivos:

I - promover e realizar estudos e pesquisas nas áreas de ensino, de desenvolvimento tecnológico e de políticas públicas;

II - promover e realizar programas e projetos científicos, tecnológicos, de inovação e de formação de pessoas na área de avaliação e seleção;

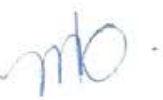


III - realizar estudos e pesquisas, desenvolver novas tecnologias e produzir informações e conhecimentos técnicos e científicos relacionados à sua finalidade;

IV - desenvolver atividades de suporte técnico e logístico a instituições públicas e privadas na área de avaliação e seleção;

$V$ - prestar serviços relacionados á sua finalidade, especialmente realizar concursos públicos, processos de seleção, exames, avaliações, certificações, acreditaçōes e correlatos; $e$

VI - fomentar as atividades de ensino, pesquisa e extensão universitária.

Parágrafo Único. O CEBRASPE utilizará todos os meios adequados para a execuçāo de sua finalidade e de seus objetivos, podendo, inclusive, desenvolver atividades acessórias, tais como, mas não limitadas a:

1 - firmar contratos, convênios, acordos, termos de parceria ou outros instrumentos congêneres com órgãos ou instituições públicas ou privadas, nacionais ou estrangeiras;

II- receber contribuições, patrocinios, auxilios, dotações, subvenções, doaçōes e legados de seus associados, de outras pessoas físicas ou jurídicas, públicas ou privadas, nacionais ou estrangeiras;

III - utilizar-se de bens móveis e imóveis que Ihe sejam disponibilizados, a qualquer titulo, por pessoas físicas ou juridicas, públicas ou privadas, nacionais ou estrangeiras, na forma que the for legalmente permitido;

IV - constituir, associar-se, titularizar cotas do capital social ou ter participação acionária em outras associações, sociedades ou fundaçôes, mediante prévia e expressa autorização do Conselho de Administração;

V - organizar, realizar, promover ou participar de eventos, debates, congressos, seminários, conferências e cursos em geral;

VI-produzir, publicar, editar, distribuir, divulgar, patrocinar e(ou) organizar, por si ou juntamente com outras instituiçôes públicas ou privadas, nacionais ou internacionais, livros, periódicos, estudos, revistas, vídeos, filmes ou documentários, fotografias ou quaisquer outros materiais, por qualquer midia ou meio digital, relacionados à sua finalidade;

VII - adotar as providências cabiveis no âmbito administrativo ou judicial, inclusive por meio de propositura de açס̄es judiciais, para a defesa dos interesses do CEBRASPE, dos seus associados e da coletividade em geral;

VIII - promover a capacitação de seus empregados, bem como de colaboradores que venham a ser contratados pelo CEBRASPE. 


\section{Capítulo III}

\section{DOS ASSOCIADOS}

Art. 6. O CEBRASPE é constituído por associados, com número máximo a ser definido no Regimento Interno do CEBRASPE, todos com afinidades com a finalidade e os objetivos da entidade, devendo a proposta de admissäo de cada um deles ser aprovada pela Diretoria e homologada pelo Conselho de Administração, na forma definida no Regimento Interno, de acordo com as seguintes categorias:

1 - fundadores: todos aqueles signatários da ata de constituição do CEBRASPE; e

II - efetivos: aqueles que formalmente pleiteiem sua admissão na forma estabelecida no Regimento Interno.

Parágrafo Único. Poderão fazer, também, parte do quadro de associados do CEBRASPE, na qualidade de membros honorários, pessoas físicas merecedoras de especial reconhecimento por relevantes serviços prestados ao desenvolvimento cientifico, tecnológico e na área da educação, que poderão ser assim distinguidas, na forma estabelecida no Regimento Interno.

Art. $7 .^{\circ}$ Poderão ser associados fundadores e efetivos do CEBRASPE:

1 - pessoas físicas que integrem ou que já tenham integrado os Conselhos Superiores da Universidade de Brasilia (UnB), ou uma de suas Câmaras; e

II - professores eméritos da Universidade de Brasília.

Parágrafo Único. Para se tornarem associados do CEBRASPE, as pessoas físicas mencionadas nos incisos 1 e $\|$ do caput deste artigo deverão apresentar proposta de admissão, que será submetida à aprovaçāo da Diretoria e à homologação do Conselho de Administração, na forma definida no Regimento Interno.

Art. $8 .^{\circ}$ Sâo direitos dos associados:

I- tomar parte nas assembleias gerais:

II - votar e ser votado para os cargos eletivos, na forma deste Estatuto e do Regimento Interno do CEBRASPE;

III - propor ao Conselho de Administração e à Diretoria qualquer medida tendente ao cumprimento das finalidades do CEBRASPE;

IV - utilizar-se dos serviços e das instalaçōes que o CEBRASPE tornar disponiveis na forma definida no Regimento Interno;

V - recorrer ao Conselho de Administração, em última instância, dos atos e resoluções da Diretoria que contrariem seus direitos;

VI- deliberar sobre a substituição de seu representante no Conselho de Administração a qualquer tempo;

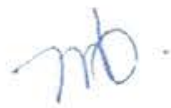


VII - participar de seminários, encontros, oficinas de trabalho e outras reunizes organizadas pelo CEBRASPE;

VIII - requerer, com pelo menos umi quinto de associados, a convocação dos órgãos deliberativos;

IX - desligar-se do quadro de associados do CEBRASPE,

$\S 1 .^{\circ}$ Aos membros honorários são assegurados os direitos previstos nos incisos I, III, IV, V, VII e IX do caput deste artigo.

$\S 2,{ }^{\circ}$ Os associados poderão ser contratados pelo CEBRASPE, em regime celetista ou de prestação de serviços, ficando suspenso seu direito a voto pelo período que perdurar o contrato.

Art. 9. São deveres dos associados:

1 - cumprir as disposiçōes estatutárias, regimentais e regulamentares;

II - acatar as decisões do Conselho de Administração e da Diretoria;

III - manter atualizadas suas informaçōes básicas;

IV - colaborar nas atividades do CEBRASPE, quando solicitados;

V - zelar pela imagem e reputação do CEBRASPE;

$\mathrm{VI}$ - desempenhar as funções para as quais tenham sido eleitos.

Parágrafo Único. Aos membros honorários incumbem os deveres previstos nos incisos I, II, III, IV e V do caput deste artigo.

Art. 10. A prática pelos associados de atos incompativeis com os fins e o decoro do CEBRASPE, com o presente Estatuto e outras normas internas, bem como com as deliberaçôes dos órgãos sociais, poderá ensejar as seguintes penalidades:

1-advertência escrita;

II - suspensão temporária dos direitos conferidos pelo presente Estatuto; e

III - exclusåo do quadro de associados;

Parágrafo Único. Competem ao Conselho de Administração o exame e a aplicação das penalidades previstas no caput deste artigo, por iniciativa própria ou mediante a recomendação da Diretoria, sendo assegurada ampla defesa do associado ou membro.

Art. 11. Os associados não respondem individual, solidária ou subsidiariamente pelas obrigaçōes do CEBRASPE. 
Capítulo IV

\section{DO PATRIMÔNIO E DAS RECEITAS}

Art. 12. Os recursos financeiros necessários à manutenção do CEBRASPE serão obtidos:

1 - por convênios firmados com órgãos e entidades governamentais ou instituiçōes privadas, nacionais ou estrangeiras, para custeio de projetos de interesse social nas áreas relacionadas à sua atividade;

II - por contratos com órgãos e entidades governamentais ou instituiçőes privadas, nacionais ou estrangeiras, para desenvolvimento e(ou) execução de projetos relacionados à finalidade da associação:

III - por contratos de produção e comercialização de bens ou serviços desenvolvidos pelo CEBRASPE:

IV - por rendimentos de aplicaçōes de seus ativos financeiros e outros pertinentes ao patrimônio sob sua administração;

V - por doaçōes, legados e heranças destinados a apoiar as atividades relacionadas à sua finalidade;

$\mathrm{VI}$ - por subvençōes sociais que Ihe forem transferidas pelo poder público;

VII - por contribuiçôes voluntárias dos associados;

VIII - pelo recebimento de royaltes e direitos autorais;

IX - por empréstimos ou financiamentos junto a organismos nacionais ou internacionais; $\theta$

$\mathrm{X}$ - por outros que porventura the forem destinados.

$\S 1 .{ }^{\circ}$ Integram o património do CEBRASPE os bens e direitos que a qualquer título the venham a ser cestinados.

§2. Os eventuais excedentes financeiros serão obrigatoriamente investidos no desenvolvimento das atividades do CEBRASPE.

§ $3^{\circ} \mathrm{O}$ CEBRASPE não distribuirá entre os seus associados, conselheiros, diretores ou doadores eventuais excedentes operacionais, brutos ou líquidos, dividendos, bonificaçōes, participaçōes ou parcelas do seu patrimônio, seja a que título for, inclusive em razão de desligamento, retirada ou falecimento de associado.

$\S 4 .^{\circ}$ O plano geral de contas discriminará as receitas, despesas e demais elementos de forma a permitir a avaliação financeira, patrimonial e de resultados do CEBRASPE.

Art. 13. No caso de extinção do CEBRASPE ou de sua desqualificação como Organizaçăo Social, nos termos da Lei Federal $n^{\circ} 9.637 / 98$, serả feita a incorporação integral do patrimônio, dos legados e das doações que lhe tenham sido destinados, bem como dos excedentes financeiros decorrentes de suas atividades, ao patrimônio 
de outra Organização Social, qualificada no âmbito da União Federal, da mesma área de atuaçäo, ou ao patrimônio da União, Estados, Distrito Federal e Municípios, na proporçăo dos recursos e bens aloçados por esses entes nos termos do contrato de gestão.

\section{Capitulo V}

\section{DA ADMINISTRAÇĀO E DA ORGANIZAÇÄO}

Art. 14. São órgãos da Administração do CEBRASPE:

I- Assembleia Geral;

II - Conselho de Administração;

III - Diretoria; e

IV - Conselho Fiscal.

Art. 15. Todos os órgâos do CEBRASPE poderão reunir-se e tomar decisões, presencial ou virtualmente, por teleconferência, por videoconferência, troca de mensagens eletrônicas, ou outro-meio de comunicação, desde que possa aferir-se a efetiva participação e manifestação da vontade dos seus membros.

Parágrafo Único. As reuniões presenciais e virtuais serão regulamentadas pelo Regimento Interno do CEBRASPE.

\section{Seção I}

\section{DA ASSEMBLEIA GERAL}

Art. 16. A Assembleia Geral constituir-se-á dos associados em pleno gozo de seus direitos estatutários e tem por competência:

I - eleger, entre os associados, um membro titular e seu suplente para o Conselho de Administração;

II - propor alteração do presente Estatuto e submetê-la ao Conselho de Administraçāo; e

III - deliberar sobre quaisquer outras matérias de interesse do CEBRASPE que the sejam submetidas pelo Conșelho de Administração.

$\$ 1 .^{\circ}$ Os associados reunir-se-ão em Assembleia Geral Ordinária a cada quatro anos para eleição, por voto direto e secreto ou por aclamação, de membro para o Conselho de Administração, ou, a qualquer tempo, em caráter extraordinário.

§2. ${ }^{\circ}$ A convocação de Assembleia Ordinária ou Extraordinária será feita pelo DiretorGeral do CEBRASPE ou por assinatura de, pelo menos, um quinto dos associados, por meio de edital afixado na sede da associação e(ou) publicado na imprensa local, por circulares ou outros meios convenientes, com antecedência minima de um mês, mencionando-se o dia, a hora, o local e a pauta da reuniảo.

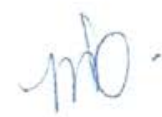


§3. A Assembleia Geral instalar-se-á, em primeira convocação, com a maioria dos associados e, em segunda convocação, com qualquer número de associados, e deliberará na forma do Regimento Interno do CEBRASPE.

Art. 17. A Assembleia Geral será instalada e presidida pelo Diretor-Geral do CEBRASPE ou, na sua ausência, por qualquer associado com direito a voto, quite com os deveres previstos no artigo $9 .^{\circ}$, e escolhido entre os presentes.

\section{Seção II}

\section{DO CONSELHO DE ADMINISTRAÇÃO}

Art. 18. O Conselho de Administração é órgão de orientação e deliberação superior.

Art. 19. O Conselho de Administraçăo, composto por onze membros titulares e respectivos suplentes, escolhidos entre pessoas de notória capacidade e reconhecida idoneidade moral, será constituido de:

I - três membros natos representantes do Poder Público, sendo:

a) um representante do Miniștério da Educação - MEC;

b) um representante do Instituto Nacional de Estudos e Pesquisas Educacionais Anísio Teixeira - INEP;

c) um representante do Ministério da Ciência, Tecnologia e Inovação-MCTI;

II - três membros natos representantes de entidades da sociedade civil, sendo:

a) um representante da Associação dos Aposentados da FUB - APOSFUB;

b) um representante da Rede Nacional de Ensino e Pesquisa - RNP;

c) um representante da Associaçäo Brasileira de Estatística - ABE;

III - um membro eleito pela Assembleia Geral entre os associados do CEBRASPE;

IV - três pessoas da comunidade acadêmica de reconhecida idoneidade moral e de notória capacidade profissional nas áreas relacionadas à finalidade do CEBRASPE, eleitos pelos demais integrantes do Conselho de Administração;

V - um membro escolhido pelo Reitor da Universidade de Brasilia, entre servidores efetivos e näo detentores de cargo em comissão ou função de confiança da referida universidade com notória contribuição às atividades de educação, ciência, tecnologia $e$ inovação.

$\S 1 .^{\circ}$ O Diretor-Geral do CEBRASPE participará das reuniōes do Conselho de Administração com direito a voz, mas não a voto.

§2. Os membros de que tratam os incisos IV e $\mathrm{V}$ terâo mandato de quatro anos, sendo permitida uma recondução.

$\S 3,^{\circ}$ Os membros natos serão indicados e substituidos a qualquer tempo.

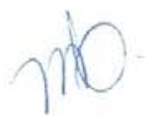


$\$ 4 .^{\circ}$ Os suplentes dos membros definidos no inciso IV, que os substituirão em seus impedimentos, seråo automaticamente aqueles que não forem eleitos como titulares.

§5. ${ }^{\circ}$ No que diz respeito aos membros referidos nos incisos I, II e V, a instituiçāo representada deverá indicar um suplente juntamente com a indicação do titular.

$\$ 6 .^{\circ}$ O primeiro mandato dos membros de que tratam os incisos I, II e III deste artigo será de dois anos e os demais mandatos terão a duração prevista no $\$ 2 .^{\circ}$ deste artigo.

Art. 20. Qualquer membro do Conselho de Administração que vier a ser indicado para integrar a Diretoria do CEBRASPE deve renunciar ao cargo de conselheiro ao assumir funçāo executiva na associação.

Art. 21. O Conselho de Administração elegerá um Presidente, entre seus membros de que tratam os incisos III, IV e V do artigo 19 deste Estatuto, para um mandato de quatro anos, admitida uma recondução.

$\$ 1 .^{\circ} \mathrm{O}$ exercício da Presidência encerrar-se-á com o término do mandato do membro do Conselho de Administração para ela eleito.

\$2. O Conselho de Administração poderá destituir seu Presidente, por decisão da maioria absoluta dos seus membros.

§3..$^{\circ}$ Em caso de vacância da Presidência, o Conselho de Administração elegerá, no prazo de trinta dias contados a partir da vacância, outro membro para a função.

Art. 22. Perderá o mandato o membro do Conselho de Administração que faltar, sem justificativa aceita, a duas reuniōes ordinárias no intervalo de doze meses.

Art. 23. No caso de vacåncia de cargo de membro do Conselho de Administraçäo, caberá ao seu Presidente solicitar a indicação ou eleição de novo membro, que completará o mandato do afastado.

Art. 24. O Conselho de Administração reunir-se-á:

1- ordinariamente, a cada tres meses; e

II - extraordinariamente, sempre que convocado por seu Presidente, por solicitaçâo de um terço de seus membros, por solicitação de um quinto dos associados do CEBRASPE ou por solicitação do Diretor-Geral.

Art. 25. As reuniões do Conselho de Administraçăo serão instaladas mediante a presença de, no minimo, metade mais um de seus membros.

Parágrafo Único. As decisões do Conselho de Administração serão adotadas desde que aprovadas por maioria simples dos membros presentes, cabendo a cada membro um voto e ao Presidente o voto de qualidade, salvo exceções previstas neste Estatuto.

Art. 26. Compete ao Conselho de Administração:

1 - deliberar sobre as linhas gerais das políticas, diretrizes e estratégias do CEBRASPE, orientando a Diretoria no cumprimento de suas atribuiçőes;

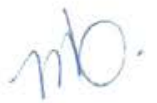


II - avaliar e aprovar os termos do Contrato de Gestão;

III - eleger seu Presidente;

IV - estabelecer as diretrizes do plano de auditoria interna, aprová-lo e modificá-lo a qualquer tempo;

$\mathrm{V}$ - determinar e autorizar a contração de auditoria externa;

VI - examinar e aprovar e, quando for o caso, remeter ao órgão supervisor do contrato de gestão os seguintes documentos:

a) proposta de orçamento, o programa de investimentos e o plano de ação para a execução das atividades do CEBRASPE;

b) relatórios de atividade, com os respectivos balancetes;

c) apresentação de contas e o relatório anual de gestão do CEBRASPE;

d) avaliação de contratos, de convênios ou de outros instrumentos de ajuste e as análises gerenciais cabiveis;

e) o Regimento Interno; $e$

f) O Regulamento próprio que deverá conter os procedimentos para aquisiçôes, contratação de obras, bens e serviços e alienações, bem como o plano de cargos e salários e beneficios dos empregados;

VII - acompanhar e avaliar periodicamente o desempenho do CEBRASPE;

VIII - designar os nomes indicados pelo Reitor da Universidade de Brasília para os cargos de Diretor-Geral e de Diretor-Executivo do CEBRASPE, conforme disposto no Estatuto;

IX - designar os membros do Conselho Fiscal;

X - designar os diretores por proposição do Diretor-Geral;

XI - fixar a remuneração do Diretor-Geral e dos Diretores;

XII - fiscalizar a gestão, apurar faltas cometidas, destituir ou aplicar penalidades cabiveis relativamente a membros da Diretoria;

XIII - avaliar e aprovar proposta de alteraçāo e políticas, diretrizes estratégicas, planos de atividades e respectivos orçamentos com exposição de motivos;

XIV - aprovar e dispor sobre alteração deste Estatuto;

XV - definir o percentual máximo da receita a ser destinado ao pagamento de remuneração, encargos trabalhistas e vantagens de qualquer natureza aos dirigentes, empregados e servidores públicos cedidos ao CEBRASPE;

XVI - aprovar, na última reunião ordinária de cada ano, o plano anual de investimentos, a ser apresentado pela Diretoria; $e$ 
XVII - aprovar a proposta de extinção da entidade e a consequente destinação do patrimônio remanescente observado o disposto no artigo 13 deste Estatuto.

$\$ 11^{\circ}$ As deliberaçōes a que se referem o inciso III, a alinea $f$ do inciso VI, o inciso VIII, 0 inciso XIV, O inciso XV, O inciso XVI e O inciso XVII serão tomadas mediante aprovação de, no minimo, dois terços dos membros do Conselho de Administração. em reunião convocada explicitamente para tais fins.

$\$ 22^{\circ}$ Os membros do Conselho de Administraçāo não podem ser contratados pelo CEBRASPE.

Art. 27. Compete ao Presidente do Conselho de Administraçāo:

1 - convocar e presidir as reuniozes do Conselho; $e$

II - indicar, para aprovação pelo Conselho, seu substituto eventual.

$\$ 1 .^{\circ}$ O Presidente do Conselho de Administração poderá decidir, ad referendum do Conselho, matéria cuja resolução, dado o caráter de urgência ou ameaça de danos à instituiçăo, nâo possa aguardar a reuniāo do órgâo.

$\S 2 .^{\circ}$ Toda decisåo tomada na forma prevista $\$ 1 .^{\circ}$ deste artigo deverá ser submetida ao Conselho de Administração para aprovação.

Seção III

\section{DA DIRETORIA}

Art. 28. O CEBRASPE será dirigido por um Diretor-Geral, um Diretor Executivo e Diretores, cabendo-thes promover, executivamente, os objetivos institucionais, segundo as diretrizes e os planos aprovados pelo Conselho de Administração.

\$1. A distribuição e O detahamento das competências dos Diretores serăo estabelecidos no Regimento Interno do CEBRASPE.

\$2, A quantidade de Diretores será definida no Regimento Interno do CEBRASPE.

Art. 29. O Diretor-Geral e o Diretor-Executivo serâo indicados pelo reitor da Universidade de Brasilia e deverão ter seus nomes aprovados e designados pelo Conselho de Administração, para mandato de quatro anos, podendo ser reconduzidos.

Parágrafo Único. Os demais Diretores serão designados pelo Conselho de Administraçăo, por indicação do Diretor-Geral do CEBRASPE.

Art. 30. Compete ao Diretor-Geral do CEBRASPE:

1 - planejar, dirigir e controlar os serviços e atividades do CEBRASPE:

II - encaminhar para a designação do Conselho de Administração, a indicaçẫo e a substituição dos Diretores;

III - convocar a Assembleia Geral e solicitar a convocação de reunião extraordinária do Conselho de Administração;

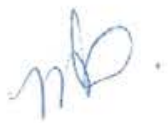


IV - autorizar despesas, promover o pagamento de obrigaçōes, assinar acordos, convênios, contratos e demais instrumentos de ajustes em conjunto com o DiretorExecutivo ou com outro Diretor do C EBRRASPE;

$\mathrm{V}$ - representar o CEBRASPE, ativa e passivamente, em juizo ou fora dele;

VI - comunicar ao Conselho de Administração, para as providências cabíveis, o afastamento irregular, a vacância do cargo, o pedido de licença ou afastamento, a infringência de normas legais regulamentares ou a ocorrência de ato que possa causar prejuizo efetivo ou potencial à imagem do CEBRASPE, relativamente aos Diretores;

VII - propor ao Conselho de Administração a oneração ou alienação de bens do ativo permanente do CEBRASPE;

VIII - constituir procuradores, mandatários ou prepostos com fins especificos, em nome do CEBRASPE, conjuntamente com o Diretor-Executivo ou com outro Diretor;

IX - gerir o patrimônio do CEBRASPE;

$\mathrm{X}$ - contratar auditoria externa para acompanhar e avaliar as contas e procedimentos gerenciais e contábeis do CEBRASPE;

$\mathrm{XI}$ - designar os ocupantes de chefias;

XII - contratar e administrar pessoal e consultorias especializadas; e

XIII - mandar publicar anualmente no Diário Oficial da União os demonstrativos financeiros e os relativos à execução de eventuais contratos de gestão com a União.

Parágrafo Único. As competências previstas nos incisos IV, IX e seguintes deste artigo poderão ser atribuídas a Diretores, na forma do Regimento Interno.

Art. 31. Perderá o cargo o Diretor que infringir as normas que disciplinam o funcionamento do CEBRASPE ou que manifestamente descumpra as suas competências, na forma do Regimento Interno.

Art, 32. Na hipótese de vacância do cargo de Diretor-Geral do CEBRASPE, as funçôes inerentes ao cargo serão assumidas pelo Diretor Executivo até nova designação pelo Conselho de Administração.

\section{Seção IV}

\section{DO CONSELHO FISCAL}

Art. 33. O Conselho Fiscal será constituído por três membros titulares e respectivos suplentes, que os substituirão em seus impedimentos, todos designados pelo Conselho de Administração.

Parágrafo Único. O Regimento Interno do CEBRASPE disporá sobre a Presidência do Conselho Fiscal, o mandato, a substituição e o afastamento dos conselheiros, bem como sobre o detalhamento de suas competências.

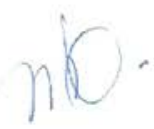


Art. 34. O Conselho Fiscal reunir-se-á periodicamente, conforme fixado em Regimento Interno, em sessões ordinárias e, extraordinariamente, quando convocado pelo Conselho de Administração.

Art. 35. Compete ao Conselho Fiscal:

I - examinar os livros de escrituração do CEBRASPE;

II - opinar sobre os balanços e relatórios de desempenho financeiro e contábil e sobre as operações patrimoniais realizadas, emitindo pareceres ao Conselho de Administração; e

III - requisitar ao Diretor responsável a documentação comprobatória das operações econômico-financeiras realizadas pelo CEBRASPE.

Art. 36. O Conselho Fiscal terá um Presidente, que será um dos Conselheiros, ao qual caberá:

I - convocar e presidir as reuniōes do Conselho Fiscal; $e$

II - indicar seu substituto ẹventual, que deverá ser submetido à aprovação do Conselho Fiscal.

\section{Capitulo VI}

\section{DOS RECURSOS HUMANOS}

Art. 37. A gestão dos empregados do CEBRASPE será feita sob o regime da Consolidação das Leis do Trabalho.

Art. 38. O regulamento de recursos humanos cuidará dos principios básicos da gestão de pessoas e disporá sobre os procedimentos quanto:

I - à seleção para admissão de pessoal;

II - aos direitos e deveres dos empregados;

III - ao regime disciplinar, às normas de apuração de responsabilidades e às penalidades;

IV - à formação e treinamento do pessoal;

V - ao plano de cargos e gratificaçâo de qualquer natureza; e

$\mathrm{VI}$ - aos salários, beneficios e vantagens para os empregados.

\section{Capítulo VII}

\section{DOS CONFLITOS DE INTERESSES}

Art. 39. Os associados, membros e integrantes dos órgâos de administração do CEBRASPE que, por qualquer motivo, tiverem interesse particular ou conflitante com o da associação deverão comunicar imediatamente o fato e absterem-se de participar de 
eventuais discussôes e deliberações relacionadas ao conflito, ainda que estejam representando terceiros.

Art. 40. Durante as Assembleias Gerais e reuniões, o associado, membro ou integrante dos órgăos de administraçăo do CEBRASPE que for parte interessada em alguma deliberação ou que tiver algum outro impedimento para tomar parte da decisão, deve declarar o conflito de interesse e abster-se de manifestar-se ou tomar parte na discussão ou deliberação.

Art. 41. Observadas as disposiçōes estatutárias e regulamentares aplicáveis à matéria, os associados, membros e integrantes dos órgãos da administração do CEBRASPE poderão ser suspensos ou desligados do quadro social ou perder seus mandatos, na forma estabelecida no Regimento Interno, sempre que:

1 - sua atuação profissional possa gerar conflitos de interesses ou comprometer institucionalmente o CEBRASPE;

II - houver eventual conflito de interesses ou situação que possa impedir sua independência na defesa da missão e prática dos princípios e valores do CEBRASPE;

III - houver situaçōes transitórtas ou permanentes que possam ferir a ética e a independência do CEBRASPE.

\section{Capitulo VIII}

\section{DAS DISPOSIÇŌES GERAIS E TRANSITÓRIAS}

Art. 42. Os membros dos Conselhos de Administraçẫo e Fiscal não receberäo remuneração pelos serviços que, nesta condição, prestarem ao CEBRASPE, ressalvada ajuda de custo.

Art. 43. Os membros dos órgãos de administraçâo do CEBRASPE deverăo ser ressarcidos, com recursos da entidade, por todos os custos, perdas e despesas incorridas em razão de atos realizados de boa-fé na representaçã̃o da associaçâo ou de quaisquer atos realizados em cumprimento de suas funções mediante aprovação do Conselho de Administração.

Art. 44. O CEBRASPE assegurará a defesa e respectivas despesas em processos judiciais e administrativos aos membros do Conselho de Administração, da Diretoria e do Conselho Fiscal, presentes e passados, para resguardá-los das responsabilidades por atos decorrentes do exercicio de suas atribuições, cobrindo todo o prazo de exercício dos respectivos mandatos.

Parágrafo Único. A garantia prevista no caput deste artigo se estende aos empregados e prepostos que legalmente atuarem por delegação dos administradores do CEBRASPE.

Art. 45. O exercicio fiscal coincidirá com o ano civil, com término no dia trinta e um de dezembro de cada ano.

Art. 46. As eventuais divergências, conflitos e omissões na aplicação do presente Estatuto serão resolvidos pelo Conselho de Administração do CEBRASPE.

13

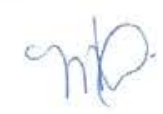


Art. 47. Na data da aprovação deste Estatuto, os membros de que tratam os incisos III e IV do artigo 19 deste Estatuto, que farão parte da primeira composição do Conselho de Administraçăo, serăo indicados, e năo eleitos, pela Assembleia Geral.

Art, 48. Na data da aprovação deste Estatuto, a Assembleia Geral designará o Diretor Provisório do CEBRASPE.

I - O Diretor Provisório será indicado pelo Reitor da Universidade de Brasília;

II - O Diretor Provisório atuará pelo prazo de 60 dias após o registro do CEBRASPE, prazo esse prorrogável por até 60 dias.

Art. 49. Este Estatuto entra em vigor após a sua aprovação e produzirá efeitos perante terceiros a partir de seu registro no Cartório de Registro de Pessoas Jurídicas.

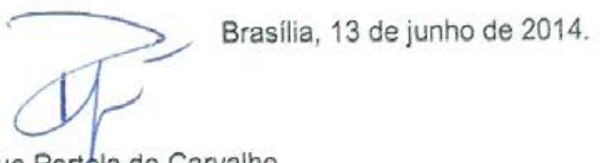

Paulo Henrique Portela de Carvalho

CPF 238.452.281-72

- Presidente

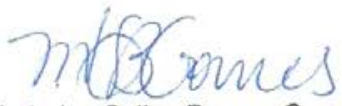

Maria Luiza Salles Borges Gomes $\mathrm{OAB} / \mathrm{DF} 13.255$

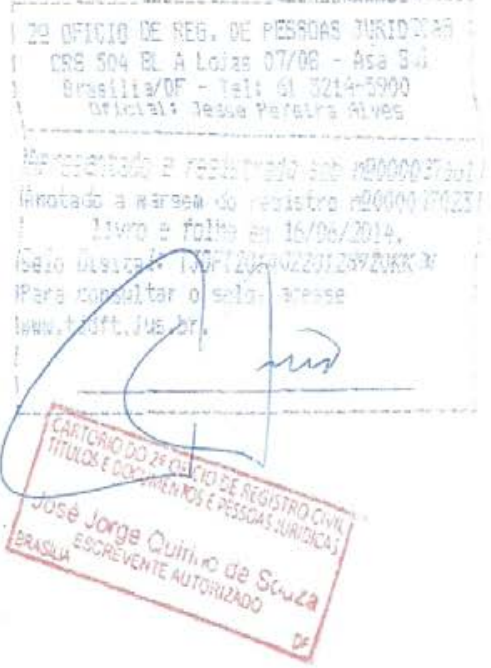




\section{ANEXO “B” - CONTRATO DE GESTÃO: CEBRASPE-MEC-FUB}

CONTRATO DE GESTÃO N² 01/14 QUE ENTRE S! CELEBRAM A UNIÃO, POR INTERMÉDIO DO MINISTÉRIO DA EDUCAÇÃO - MEC, COM A INTERVENIENNCIA DA FUNDAÇÃO UNIVERSIDADE DE BRASILIA - FUB E DO INSTITUTO NACIONAL DE ESTUDOS E PESQUISAS EDUCACIONAIS ANISIO TEIXEIRA INEP E O CENTRO BRASILEIRO DE PESQUISA EM AVALIAÇÃO E SELEÇÃO E DE PROMOÇÄO DE EVENTOS - CEBRASPE.

A UNIĀO, por intermédio do MINISTÉRIO DA EDUCAÇÃO MEC, com sede na Esplanada dos Ministérios, Bloco L, Brasília-DF, CEP 70047-900, CNPJ/MF no 00.394.444/0001-01, neste ato representado por seu titular, o Ministro de Estado da Educaçāo, JOSÉ HERINQUE PAIM FERNANDES, nacionalidade brasileira, casado, portador da Carteira de Identidade no 302.527.5544 SSPIRS e CPF $n^{Q}$ 419.944.340-15, residente e domiciliado em Brasilia-DF, designado pelo Decreto $\mathrm{s} / \mathrm{n}$, de 31 de janeiro de 2014, publicado no Diário Oficial da Uniăo de 3 de fevereiro de 2014, e no uso da competência que the foi delegada, doravante denominado simplesmente ORGÃO SUPERVISOR, O CENTRO BRASILEIRO DE PESQUISA EM AVALIAÇÃO E SELEÇÃO E DE PROMOÇÄO DE EVENTOS - CEBRASPE, Associação Civil, qualificada como Organizaçăo Social por meio do Decreto $n^{0} 8.038$, de 19 de agosto de 2013, doravante denominado CEBRASPE, representada neste ato por seu Diretor-Geral, PAULO HENRIQUE PORTELA DE CARVALHO, portador da Carteira de Identidade $n^{2} 712767$ SSP/DF e CPF $n^{2} 238.452 .281-72$. FUNDAÇĀO UNIVERSIDADE DE BRASILIA - FUB, fundação de direito público criada pela Lei $n^{2} 3.998$, de 15 de dezembro de 1961 , regida pela Lei $n^{\circ} 5.540$, de 28 de novembro de 1968, com sede no Campus Universitário - Asa Norte, em Brasilia-DF, inscrita no CNPJ/MF sob o $\mathrm{n}^{\circ} 00.038 .174 / 0001-43$, representada neste ato por seu Reitor IVAN MARQUES DE TOLEDO CAMARGO, portador da Carteira de Identidade $n^{2} 581.564$ SSPIDF e CPF $n^{2} 210.411 .481-00$, residente e domiciliado nesta Capital, nomeado pelo Decreto $s / n$, de 14 de novembro de 2012, publicado no Diário Oficial da Uniăo de 16 de novembro de 2012, e no uso de competência de seus Estatutos, como PRIMEIRA INTERVENIENTE, ๑ O INSTITUTO NACIONAL DE ESTUDOS E PESQUISAS EDUCACIONAIS ANISIO TEIXEIRA - INEP, autarquia federal vinculada ao MEC nos termos da Lei $n^{2} 9.448$, de 14 de março de 1997 , alterada pela Lei $n^{\circ}$ 
10.269, de29 de agosto de 2001, representada neste ato por seu Presidente JOSÉ FRANCISCO SOARES, portador da Carteira de Identidade n 401.091 SSP/MG e CPF n 133.666.616-15, residente e domiciliado nesta Capital, nomeado pela Portaria no 94 , de 12 de fevereiro de 2014, publicada no Diário Oficial da União de 13 de fevereiro de 2014, como SEGUNDO INTERVENIENTE, resolvem firmar o presente CONTRATO DE GESTÃO, que será regido pelas cláusulas e condições que se seguem:

\section{CLÁUSULA PRIMEIRA - DO OBJETO}

O presente Contrato de Gestăo tem por objeto o estabelecimento de parceria entre as partes relacionadas nas atividades de gestäo de programas, projetos, apoio técnico e logístico para subsidiar sistemas de avaliação educacional.

SUBCLÁUSULA PRIMEIRA - Para o alcance da finalidade assinalada, visa o presente contrato especificar o Programa de Trabalho a ser desenvolvido, anexo a este instrumento, e as metas a serem alcançadas pelo CEBRASPE, conforme obrigaçōes e responsabilidades aqui firmiadas pelas partes, bem como estabelecer as condiçöes para a sua execução, os critérios de avaliação e os indicadores de desempenho.

SUBCLÁUSULA SEGUNDA - O Programa de Trabalho para o periodo de 2014 a 2019, constante do Anexo II, e a proposta de cronograma de desembolso, constante do Anexo IV, será pactuada anualmente, dele fazendo parte integrante, independentemente de transcrição, para todos os efeitos legais e de direito.

SUBCLÁUSULA TERCEIRA - O conjunto de indicadores e metas de desempenho poderá ser revisto, sempre que necessário e a qualquer tempo, mediante negociação entre o ÓRGÃO SUPERVISOR e o CEBRASPE.

SUBCLAUSULA QUARTA - O Plano de Açăo para as atividades do CEBRASPE será pactuado, anualmente, por meio de Termo Aditivo ao Contrato de Gestão.

SUBCLÁUSULA QUINTA - O presente contrato de gestão tem por objetivo o planejamento e/ou a realizaçăo das avaliaçōes educacionais realizadas pelo INEP.

\section{CLÁUSULA SEGUNDA - DOS OBJETIVOS ESTRATÉGICOS}

O Programa de Trabalho para o CEBRASPE, constante do Anexo II deste instrumento, para o periodo de 2014 a 2019, orienta as atividades a serem desenvolvidas no âmbito deste Contrato de Gestão e busca alcançar os seguintes objetivos estratégicos na área de avaliação:

I - estruturar e fortalecer, institucionalmente, o CEBRASPE, para garantir o ambiente organizacional necessário para a realizaçăo com eficiência das grandes avaliaçöes e seleçōes nacionais;

II - executar avaliaçőes nas áreas de ensino e desenvolvimento institucional, que podem subsidiar estudos, pesquisas e seleçőes;

III - executar, nas áreas de avaliação e seleção, projetos científicos e tecnológicos e programas de inovação e de formação de pessoas; $e$

IV - desenvolver novas tecnologias e produzir informaçōes e conhecimentos técnicos e científicos relacionados ao ensino, à pesquisa científica, ao desenvolvimento tecnológico e institucional nas áreas de avaliação e seleçāo.
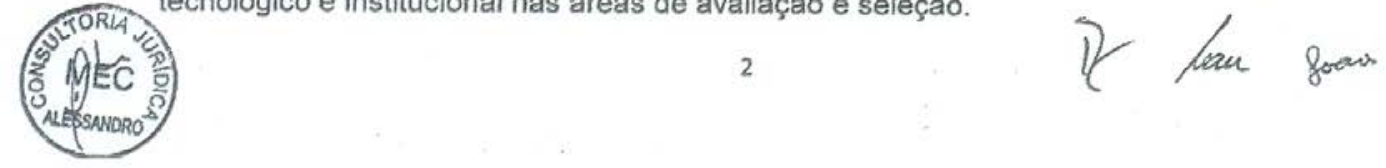


\section{CLÁUSULA TERCEIRA - DAS OBRIGAÇŌES DO CEBRASPE O CEBRASPE obriga-se a:} I - observar, na condução dos processos, trabalhos técnịcos e de pesquisa, as
diretrizes do ORGÄO SUPERVISOR expressas no Anexo l;

II - cumprir o Programa de Trabalho relacionado no Anexo II, contribuindo para o alcance dos objetivos estratégicos enumerados na Cláusula Segunda deste
instrumento contratual; III - cumprir com a Sistemática de avaliação constante do Anexo III, de forma a atingir
as metas estabelecidas e seus indicadores;

IV - apresentar, anualmente, ao ORGĀO SUPERVISOR, no prazo e forma por ele definido, o Plano de Ação Anual, organizado segundo Linhas de Atividades, a previsăo de despesas detalhadas, indicando suas vinculações aos objetivos estratégicos constantes da Clâusula Segunda deste contrato, as ementas descritivas das açöes/subaçōes, bem como proposta de Quadro de Indicadores e Metas e da proposta do Cronograma de Desembolso dos recursos a serem repassados;

$V$ - manter atualizada a publicação no sítio do CEBRASPE - www.cespeunb-os.org.br - na internet, dos regulamentos próprios de pessoal e recursos humanos e de compras e contratações de bens e serviços, com emprego de recursos provenientes do Poder Público, nos termos do art. 17 da Lei n 9.637, de 15 de maio de 1998, observados os principios da legalidade, da moralidade, da publicidade, da economicidade e da impessoalidade;

$\mathrm{VI}$ - permitir o uso das publicaçōes do CEBRASPE pelo ÓRGÃO SUPERVISOR e a sua divulgação no sitio do MEC (www.mec.gov.br) na internet, ressalvadas situaçōes comprovadas e compromissos assumidos com terceiros;

VII - elaborar e encaminhar ao ÓRGÃO SUPERVISOR, após devidamente aprovados pelo Conselho de Administraçăo, os relatórios gerenciais de atividades detalhados na forma e prazo por este definido;

VIII - aplicar em todas as peças e materiais promocionais e comunicação externa, inclusive por meio eletrônico, eventos, livros e demais publicaçőes de natureza técnica, cientifica e didática relacionadas a este Contrato de Gestąo, assim como em lugar visivel de suas edificaçőes, placas, painéis e outros suportes de comunicação visual que identifiquem obras e projetos de obras, as logomarcas oficiais do MEC e do Governo Federal, mediante autorizaçăo expressa e prévia nos termos da Instruçăo Normativa $n^{\circ} 02$, de 16 de dezembro de 2009, da Secretaria de Comunicaçăo da Presidência da República;

IX - manter a contabilização dos recursos financeiros repassados de forma segregada de outras fontes, em conta bancária específica, evidenciando as receitas e despesas relacionadas ao Contrato de Gestão;

$X$ - proceder à gestão dos recursos humanos cedidos e providenciar os registros funcionais destes junto aos respectivos órgåos de origem;

$\mathrm{XI}$ - administrar os bens móveis e imóveis a ele cedidos, assim como aplicar os recursos financeiros que the forem repassados pelo ORGÃO SUPERVISOR exclusivamente na consecução dos objetivos estratégicos e as metas previstas neste 
instrumento, sem prejuizo do disposto na alínea " $b$ " do inciso I do art. $2^{2}$ da Lei $n^{\circ}$ 9.637, de 1998;

XII - encaminhar ao ÓRGĀO SUPERVISOR as eventuais alterações estatutárias e de regulamentos próprios devidamente aprovados pelo Conselho de Administraçăo;

XIII - reprogramar eventuais saldos financeiros apurados em 31 de dezembro de cada ano por ocasião do primeiro Termo Aditivo do exercício subsequente;

XIV - adequar-se às regulamentaçס̃es normativas emanadas do ÓRGÃO SUPERVISOR que repercutam no presente Contrato de Gestão;

XV - realizar os pagamentos referidos nos incisos II e III da Cláusula Quarta deste contrato, nos moldes a serem definidos em contrato(s) a ser(em) firmado(s) com a INTERVENIENTE; e

$\mathrm{XVI}$ - publicar, no prazo máximo de noventa dias, contado da assinatura do contrato de gestão, regulamento próprio contendo os procedimentos que adotará para a contração de obras e serviços, bem c९mo para compras com emprego de recursos provenientes do Poder Público, conforme previsto no art. 17 da Lei $n^{2}$ 9.637, de 1998.

\section{CLAUUSULA QUARTA - DAS OBRIGAÇÖES DA PRIMEIRA INTERVENIENTE - FUB \\ A PRIMEIRA INTERVENIENTE obriga-se a:}

1 - ceder ao CEBRASPE, os servidores da FUB, necessários ao fortalecimento institucional do CEBRASPE e a realização das atividades inerentes ao contrato de gestão, assumindo o ônus decorrente dessa cessão, nos termos do art. 14 da Lei $n^{0}$ 9.637, de 1998, e do art. $4^{2}$ da Lei $n^{0} 12,863$, de 24 de setembro de 2013.

II - ceder, onerosamente, ao CEBRASPE o imóvel em que está instalado o Centro de Seleção e de Promoção de Eventos - CESPE/UnB, bem como todos os bens móveis que o guarnecem, inclusive computadores, impressoras, telefones, parque gráfico, e outros;

III - ceder, onerosamente, ao CEBRASPE a marca CESPE, o seu acervo técnico, incluidos ai os seus atestados de capacidade técnica, os sistemas tecnológicos por ele desenvolvidos, os seus domínios de internet, os direitos autorais referentes a provas por ele elaboradas e aplicadas, seus arquivos com cadastros de colaboradores, de candidatos de concursos e processos seletivos públicos, entre outros;

IV - repassar ao CEBRASPE os recursos existentes na conta única do Tesouro Nacional vinculados à Unidade Gestora CESPE necessários à execução dos contratos que the serảo sub-rogados; e

$\checkmark$ - cumprir procedimentos e prazos pactuados para a negociação, renovação ou aditamento deste Contrato de Gestão.

\section{CLÁUSULA QUINTA - DAS OBRIGAÇŐES DO SEGUNDO INTERVENIENTE - INEP O SEGUNDO INTERVENIENTE obriga-se a:}

1 - contratar o CEBRASPE para dar apoio técnico e logístico nas avaliaçőes educacionais por ele realizadas, em parceria ou năo com outra(s) instituç̧ăo(őes);

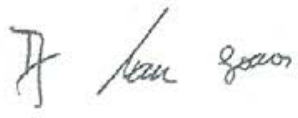


II - promover o desembolso financeiro, de acordo com o cronograma pactuado
anualmente; $e$ III - cumprir procedimentos e prazos pactuados para a negociação, renovação ou aditamento deste Contrato de Gestão.

\section{CLÁUSULA SEXTA - DAS OBRIGAÇÖES DO ÓRGÃO SUPERVISOR O ÓRGÃO SUPERVISOR obriga-se a:} I - providenciar a consignação de dotaçăo financeira destinada à implantação do
CEBRASPE na condição de Organizaçăo Social;

II - acompanhar e avaliar o cumprimento das metas de desempenho pactuadas para cada ano de vigência deste Contrato de Gestão; III - caso haja necessidade de repasse de recurso pelo ÓRGĀO SUPERVISOR, dar-se-
á por meio de termo aditivo;

IV - analisar os relatórios da Comissão de Avaliação, de que trata a Cláusula Décima
Segunda;

$\checkmark$ - providenciar, anualmente, a consignação das dotaçőes destinadas a custear este Contrato de Gestão no Projeto de Lei Orçamentária, inclusive os valores referentes a reserva técnica financeira prevista na cláusula oitava deste contrato; $\mathrm{VI}$ - cumprir procedimentos e prazos pactuados para a negociaçăo, renovação ou
aditamento deste Contrato de Gestäo.

\section{CLÁUSULA SÉTIMA - DOS TETOS REMUNERATÓRIOS}

A Organizaçăo Social deverá observar, conforme decisăo do Conselho de Administração, o limite de $40 \%$ (quarenta por cento) do orçamento do CEBRASPE para a serem percebidos pelos com remuneração e vantagens de qualquer natureza exercicio percebidos pelos dirigentes e empregados das organizaçôes sociais, no 9.637, de 1998.

\section{CLÁUSULA OITAVA - DOS RECURSOS FINANCEIROS}

Para o cumprimento das metas pactuadas neste instrumento, fica estimado - valor global de recursos orçamentários destinados ao CEBRASPE, por meio deste contrato, no montante de $\mathrm{R} \$ \mathbf{8} .135 .467,20$ (oito milhŏes cento e trinta e cinco mil quatrocentos e sessenta e sete reais e vinte centavos) para o periodo de 2014 a 2019 , e correrão à conta do Programa de Trabalho do CESPE, oriundos de açẫo de fomento/projeto específica autorizada na Lei Orçamentária Anual e obedecerão às normas que regem o orçamento da Uniăo e às orientaçőes do Ministério do Planejamento, Orçamento e Gestão sobre o tema.

SUBCLAUSULA PRIMEIRA - O valor único a ser repassado pela PRIMEIRA INTERVENIENTE, bem como os valores anuais a serem repassados pelo ÓRGĀO SUPERVISOR e pelo SEGUNDO INTERVENIENTE, a titulo de fomento, estäo estimados nos seguintes montantes:
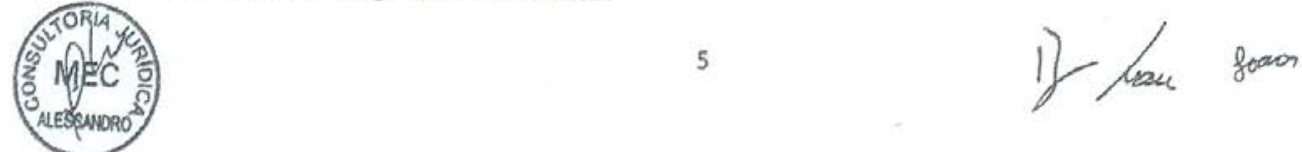


\begin{tabular}{|c|c|c|c|}
\hline ANO & MEC & INEP & FUB \\
\hline 2014 & - & R\$2.324.419,20 & \\
\hline 2015 & - & $R \$ 1.162 .209,60$ & \multirow{2}{*}{$\begin{array}{c}\text { Recursos do CESPE/UnB } \\
\text { existentes na conta única do } \\
\text { Tesouro Nacional }\end{array}$} \\
\hline 2016 & - & $R \$ 1.162 .209,60$ & \\
\hline 2017 & - & $R \$ 1.162 .209,60$ & \\
\hline 2018 & - & $R \$ 1.162 .209,60$ & \\
\hline 2019 & - & $R \$ 1.162 .209,60$ & \\
\hline TOTAL & - & $R \$ 8.135 .467,20$ & \\
\hline
\end{tabular}

SUBCLAUSULA SEGUNDA - Os recursos anuais a serem repassados anualmente ao CEBRASPE, a título de fomento, poderăo ser aplicados no mercado financeiro, desde Contrato de Gestão sem aplicaçäo revertam exclusivamente aos objetivos deste 9.637, de 1998.

SUBCLÁUSULA TERCEIRA - A alteraçăo de valores implicará a revisăo das metas pactuadas, assim como a revisão das metas implicará a alteraçăo do valor global dos

SUBCLÁUSULA QUARTA - O ORGÃO SUPERVISOR compromete-se a fazer os exercícios subsequentes. SUBCLÁUSULA QUINTA - As aquisiçōes e contratações de bens e serviços comuns a deverão ser efetuadas mediante Regum recursos oriundos do Contrato de Geståo, Rulamento de Compras da entidade.

SUBCLÁUSULA SEXTA - A deliberação, no Conselho de Administraçăo, de questōes com recursos do Contrato de despesa, de qualquer natureza, a serem cobertas ORGÃO SUPERVISOR.

\section{CLÁUSULA NONA - DA RESERVA TÉCNICA FINANCEIRA}

Com a finalidade de assegurar condiçőes de operação, O CEBRASPE adotará providências para a constituição de uma reserva técnica de natureza financeira para utílização nas seguintes situaçōes:

1. custeio das atividades básicas do CEBRASPE;

II. pagamentos de contratos e direitos trabalhistas, em casos năo previstos; $\mathrm{e}$ III. outros gastos em atividades de relevante interesse para os objetivos do Contrato
de Gestão.

SUBCLAUSULA PRIMEIRA - Os recursos para a composição da reserva técnica serão constituidos de saldos financeiros de exercícios anteriores e resultados de aplicação
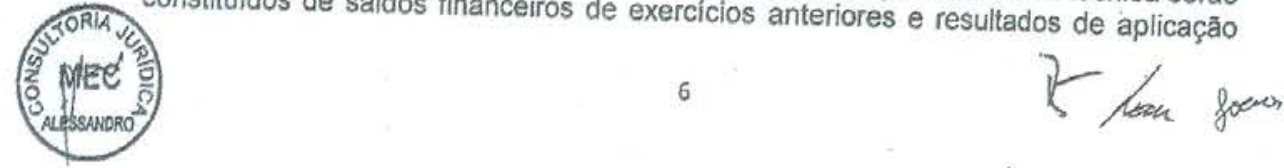
financeira destes, em montante que assegure o custeio do CEBRASPE por periodo năo superior a 8 (oito) meses.

SUBCLÁUSULA SEGUNDA - A reserva técnica deverá ser utilizada, preferencialmente, nas despesas relacionadas à execução do objeto do Contrato de
Gestão.

SUBCLAUSULA TERCEIRA - A reserva técnica que se destine a investimento em atividades relevantes deverá ser identificada e reprogramada por meio de Termo
Aditivo no respectivo ano.

\section{CLÁUSULA DÉCIMA - DOS RECURSOS HUMANOS}

Observados os efeitos de eventuais repactuaçōes orçamentárias, o CEBRASPE poderá gastar percentual, a ser estabelecido pelo Conselho de Administração, dos recursos financeiros a este repassados, com despesas de remuneração, encargos trạbalhistas e vantagens de qualquer natureza a serem percebidos pelos seus dirigentes, empregados e servidores públicos cedidos.

SUBCLÁUSULA PRIMEIRA - O CEBRASPE deverá, sempre que requerido pelo ORGÃO SUPERVISOR, apresentar planilha de cargos e salários detalhada e atualizada.

SUBCLÁUSULA SEGUNDA - A cessão ao CEBRASPE de servidores públicos, conforme Anexo V, para atendimento do objeto do presente Contrato, dar-se-á mediante as condiçóes estabelecidas nos parágrafos do art. 14 da Lei $n^{2} 9.637$, de 1998, e na Lei n 12.863, de 2013.

SUBCLÁUSULA TERCEIRA - A utilizaçăo de pessoal que, além dos servidores públicos federais cedidos, se tornar necessária para a execução dos serviços previstos no presente Contrato, nāo configurará vinculo empregaticio de qualquer natureza, nem gerará qualquer tipo de obrigação trabalhista ou previdenciária para o ÓRGÃO SUPERVISOR.

SUBCLÁUSULA QUARTA - O CEBRASPE compromete-se a não ceder a qualquer instituição pública ou privada seus empregados, remunerados com recursos repassados pelo ORGÄO SUPERVISOR, durante o prazo deste Contrato.

SUBCLÁUSULA QUINTA - A capacitaçăo dos servidores cedidos será promovida $e$, quando couber, custeada pelo CEBRASPE, cabendo a este autorizar a participaçäo em eventos, ocorridos no País ou no exterior, observada a necessidade de registro nas respectivas pastas funcionais.

\section{CLÁUSULA DÉCIMA PRIMEIRA - DOS BENS ADQUIRIDOS COM RECURSOS DO CONTRATO DE GESTÃO}

Os bens adquiridos com recursos do Contrato de Gestão, passiveis de serem incorporados ao ativo da Uniäo conforme previsăo do artigo $2^{\circ}$, inciso I, da Lei $n^{Q}$ 9.637, de 1998, deveräo ser registrados com identificação especifica.

SUBCLÁUSULA ÚNICA - A relação de bens adquiridos com recursos dos Contratos de Gestão poderá ser solicitada pelo ÓRGÄO SUPERVISOR a qualquer tempo.

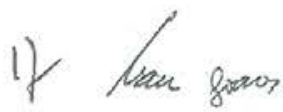




\section{CLÁUSULA DÉCIMA SEGUNDA - DA CESSÃO E DA ADMINISTRAÇÃO DOS BENS
PÚBLICOS}

Serăo cedidos ao CEBRASPE, a título de cessão de uso onerosa, nos termos da legislação pertinente, e pelo prazo do presente Contrato de Gestão, os bens móveis e imóveis, equipamentos e instalaçöes, conforme arrolamento constante do Anexo IV e demais disposiçőes legais que regem a matéria, cabendo ao CEBRASPE mantê-los e deles cuidar como se seus fossem.

SUBCLÁUSULA ÚNICA - Os bens móveis cedidos na forma desta cláusula poderão, mediante prévia avaliação e expressa autorização do ÓRGÃO SUPERVISOR, ser alienados e substituidos por outros de igual ou maior valor, condicionado a que os novos bens integrem, concomitantemente, mediante termo de doaçāo expresso, patrimônio da FUB.

\section{CLÁUSULA DÉCIMA TERCEIRA - DA FISCALIZAÇÃO, DO ACOMPANHAMENTO E DA AVALIAÇÄO DE RESULTADOS}

No âmbito deste Contrato de Gestäo, o ORGÄO SUPERVISOR será responsável pela fiscalização de sua execução, cabendo-lhe, ainda, a supervisão, o acompanhamento e a avaliação do desempenho do CEBRASPE, de acordo com os objetivos estratégicos definidos na Cláusula Segunda, os indicadores e as metas de desempenho e a sistemática de avaliaçăo constante do Anexo III deste Contrato de Gestảo e, também, de acordo com a Lei $n^{\circ} 9.637$, de 1998, e as demais regulamentaçōes pertinentes, especialmente as Portarias editadas pelo MEC.

SUBCLAUUSULA PRIMEIRA - O ORGÄO SUPERVISOR constituirá, em até noventa dias da assinatura deste Contrato de Gestão, sua Comissão de Avaliação que analisará, periodicamente, os resultados e metas atingidos na execução dos objetivos previstos neste instrumento contratual.

SUBCLÁUSULA SEGUNDA - A Comissầo de Avaliação acima prevista será presidida por um especialista indicado pelo ORGÃO SUPERVISOR, conforme regras e critérios definidos em Portaria do MEC.

SUBCLÁUSULA TERCEIRA - A Comissão de Avaliação reunir-se-á, no mínimo, semestralmente, em data previamente definida entre as Partes, para:

I. acompanhar e avaliar os resultados alcançados peio CEBRASPE, em face das metas e indicadores de desempenho pactuados anualmente, na perspectiva de sua eficácia, de sua eficiência e de sua efetividade; $\Theta$

II. propor a revisăo das metas e dos indicadores, sempre que necessário.

SUBCLÁUSULA QUARTA - As recomendaçóes da Comissằo de Avaliaçăo ao ÓRGÃo SUPERVISOR e ao CEBRASPE servirão, no que entenderem cabivel, para adequaçőes deste Contrato de Gestão.

SUBCLAUUSULA QUINTA - O CEBRASPE encaminhará ao ÓRGÃO SUPERVISOR, que, por sua vez, encaminhará à Comissăo de Avaliaçäo, com até dez dias dé antecedência de suas reuniőes, relatório sobre o seu desempenho e realizaçőes no cumprimento das metas e obrigações previstas neste Contrato de Geståo.

SUBCLAUSULA SEXTA - A Comissâo de Avaliação apresentará ao ORGÃO SUPERVISOR, no prazo máximo de 10 (dez) dias, após o encerramento da Reunião

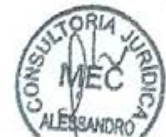

8

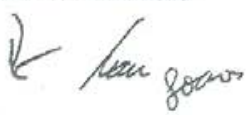


de Avaliação Anual, o relatório conclusivo da análise dos resultados atingidos com a Anual.

\section{CLAUSULA DÉCIMA QUARTA - DA PRESTAÇÃO DE CONTAS}

O CEBRASPE elaborará e apresentará ao ÓRGÄO SUPERVISOR relatórios circunstanciados anuais de execução deste Contrato de Gestăo, comparando os resultados alcançados com as metas previstas, acompanhado de demonstrativo da dequada utilização dos recursos provenientes do Poder Público, das análises gerenciais cabiveis e de parecer técnico sobre o periodo em queståo.

SUBCLÁUSULA PRIMEIRA - O ORGÃO SUPERVISOR poderá exigir do CEBRASPE, a qualquer tempo, informaçōes complementares e detalhamento de tópicos e informaçōes constantes dos relatórios.

SUBCLAUSULA SEGUNDA - O CEBRASPE encaminhará ao ORGÃO SUPERVISOR, até $1^{2}$ de março de cada ano, a documentação referente ao processo de prestação de relativamente a este Contrato anterior, aprovados pelo Conselho de Administraçäo,

SUBCLÁUSULA TERCEIRA - Caberá ao CEBRASPE promover, até 15 de março de cada ano, a publicaçäo no Diário Oficial da Uniảo e em jornal de circulaçäo naçonal dos relatórios financeiros e de execuçăo deste Contrato de Gestão relativos ao deverá promove deverá promover a divulgaçäo desses documentos em meio eletrônico.

\section{CLAUUSULA DÉCIMA QUINTA - DA VIGÊNCIA E DAS ALTERAÇŌES CONTRATUAIS}

O presente Contrato de Gestão vigorará de 18 de fevereiro de 2014 até 31 de dezembro de 2019, e poderá ser renovado, por período a ser definido em processo de negociaçăo, ou ter seu prazo dilatado, após demonstrada a consecuçăo dos objetivos estratégicos, das metas estabelecidas e a avaliação favorável do ORGẢO SUPERVISOR, obedecido o prazo estatuído na Subcláusula Segunda desta Cláusula. SUBCLÁUSULA PRIMEIRA - As partes deverăo se manifestar sobre o interesse na renovação do Contrato de Gestão, com antecedência de pelo menos 12 (doze) meses da data final de sua vigência, devendo ser ouvida a Comissăo de Avaliação,

SUBCLÁUSULA SEGUNDA - Todo e qualquer processo de negociação para a renovaçåo ou repactuação total deste Contrato de Gestâo deverá ser iniciado no periodo de 12 (doze) meses anteriores à data final de sua vigência.

SUBCLÁUSULA TERCEIRA - A repactuação, parcial ou total, deste Contrato de Gestão, formalizada mediante Termo Aditivo, poderá ocorrer:

I. por recomendaçăo da Comissâo de Avaliação, para ajuste das metas e revisão de indicadores, resultantes das reuniöes de acompanhamento e de avaliação de que trata a Cláusula Décima Segunda; II. para adequaçōes do Programa de Trabalho em face da evolução científica ou
tecnológica;

III. para adequaçåo à Lei Orçamentária Anual;

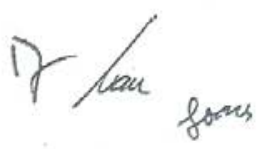



IV. para adequação às novas políticas de governo que inviabilizem a execução de
atividades nas condiçőes contratuais originalmente pactuadas; $e$

$\mathrm{V}$

Geral da União, por meio de seus órgãos, ntą̧ōes jurídicas emanadas pela Advocacia-

\section{CLAUUSULA DÉCIMA SEXTA - DA RESCISÃO}

O presente Contrato de Gestão poderá ser rescindido, a qualquer tempo, por acordo entre as Partes ou administrativamente, independentemente das demais medidas legais cabiveis e mediante aviso com antecedência mínima de 120 (cento e

I. se houver descumprimento por parte do CEBRASPE das cláusulas, dos objetivos e metas, decorrentes da má gestão, culpa, dolo ou violação da lei;

II. na hipótese de não atendimento às recomendaçőes decorrentes das realizadas pela Comissăo de Avaliação, que tenhąçes decorrentes das avaliaçőes SUPERVISOR, na forma deste Contrato, que tenham sido avaliadas pelo ORGÃO Costão; e

III. se houver alteraçōes no Estatuto do CEBRASPE que impliquem modificaçăo das Contrato.

SUBCLAUSULA PRIMEIRA - A rescisăo administrativa será precedida de processo administrativo, assegurados $\circ$ contraditório e a ampla defesa, nos termos da
Constítuição Federal.

SUBCLÁUSULA SEGUNDA - Havendo pendências, as partes definirão as responsabilidades pela conclusảo ou encerramento de cada um dos trabalhos e todas Encerramento.

\section{CLÁUSULA DÉCIMA SÉTIMA - DO PLANO DE AÇÃO ANUAL - 2014}

As açōes e subaçöes a serem executadas com recursos financeiros alocados para o ano de 2014 seräo pactuadas em Termo Aditivo a ser firmado no prazo de 30 (trinta) dias a contar da assinatura deste contrato.

SUBCLÁUSULA PRIMEIRA - O Termo Aditivo de que trata o caput desta cláusula atividades, o prazo de excrção das açōes e subações dentro de suas linhas de detalhadas por objeto de -, bem como proposta de Quadro de indinas vinculaçōes aos objetivos estratégicos desembolso dos recuro de cronograma de Seserem repassados pelo ORGĀO SUPERVISOR.

SUBCLAUSULA SEGUNDA - Caso haja necessidade de repasse de recurso pelo ORGÃO SUPERVISOR, dar-se-á por meio de termo aditivo.

\section{CLAUUSULA DÉCIMA OITAVA - DA SUSPENSÄO}

Durante a execução dos serviços avençados neste instrumento onde se verifique mudanças substanciais no contexto das condiçőes estabelecidas, as partes

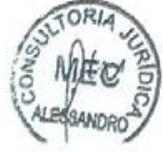


poderāo suspender a continuidade das atividades, para readequação das metas
necessárias à consecuçẫo do objeto.

SUBCLÁUSULA ÚNICA - As readequaçōes ocorridas durante a vigência do presente instrumento deverăo ser lavradas mediante a formalizaçåo de Termo Aditivo.

\section{CLAUSULA DÉCIMA NONA - DA DESQUALIFICAÇÃO}

De acordo com o art. 16 da Lei $n^{2} 9.637$, de 1998, O ÓRGÄO SUPERVISOR poderá proceder à desqualificaçăo da entidade como organização social, quando constatado o descumprimento das disposiçőes contidas no contrato de gestäo.

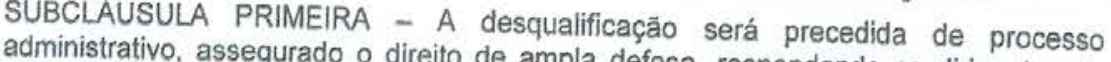
organizaçăo social, individual direito de ampla defesa, respondendo os dirigentes da de sua ação ou omissão.

SUBCLÁUSULA SEGUNDA - A desqualificação importará reversão dos bens permitidos e dos valores entregues à utilização da organizaçấo social, sem prejuizo de
outras sançôes cabiveis.

SUBCLÁUSULA TERCEIRA - O näo atendimento das metas e indicadores poderá acarretar em aplicação de notificação pelo ÓRGĀO SUPERVISOR, sendo que na terceira notificaçăo poderá ser iniciado o processo de desqualificaçăo da Organização
Social.

\section{CLAUUSULA VIGÉSIMA - DA SUBCONTRATAÇÃO} contrato.

É expressamente vedada a subcontratação, ainda que parcial, do objeto do

SUBCLÁUSULA ÚNICA - No caso de descumprimento desta Cláusula, será rescindido o contrato, e a Organizaçäo Social poderá ser cobrada por eventuais prejuízos.

\section{CLÁUSULA VIGÉSIMA PRIMEIRA - DA PUBLICIDADE}

O presente instrumento será publicado, pelo ÓRGÅO SUPERVISOR, no prazo de 30 (trinta) dias, na forma de extrato no Diário Oficial da União - DOU e na integra em seu sítio na internet - www.mec.gov.br.

\section{CLÁUSULA VIGÉSIMA SEGUNDA - DO FORO}

Fica eleito o Foro da Justiça Federal - Seção Judiciária do Distrito Federal, na forma do art. 111, caput, do Código de Processo Civil, com exclusão de qualquer outro, por mais privilegiado que seja, para dirimir quaisquer dúvidas do presente
instrumento.

SUBCLÁUSULA ÚNICA - As Partes concordam que eventuais divergências jurídicas surgidas derivadas da execução deste Contrato de Gestăo sejam previamente submetidas à mediaçăo da Câmara de Conciliação e Arbitragem da Administraçăo Federal - CCAF da Advocacia-Geral da Uniāo, antes da interposição de ação judicial.

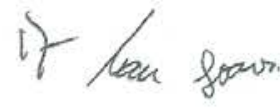


E por estarem, assim, justas e acordadas, firmam as partes o presente Contrato de Gestâo em duas vias de igual teor e forma e para os mesmos fins de direito.

Brasilia - DF, 18 de fevereiro de 2014.
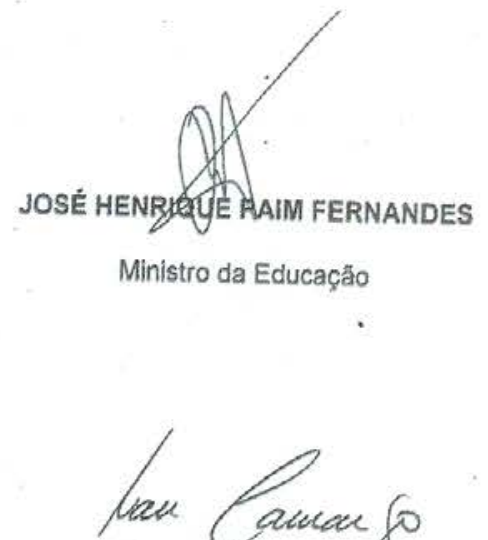

IVAN MARQUES DE TOLEEO CAMARGO

Reitor da Fundaçăo Universidade de Brasilia - DF - Primeiro Interveniente

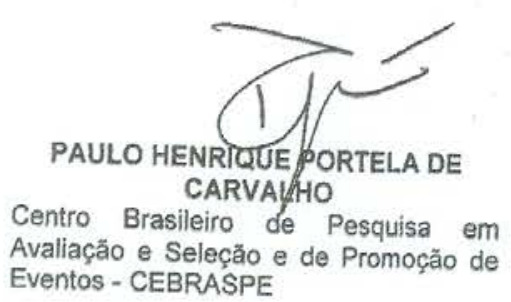

$$
\begin{aligned}
& \text { fosé fromeineo fores } \\
& \text { JOSÉ FRANCISCO SOARES }
\end{aligned}
$$

Presidente do INEP - Segundo Interveniente<smiles>CC(C)(C)C1CC1(C)C1(C)CCCCN(C(=O)O)C1</smiles>

NOME:

CPF

ID: 


\section{ANEXO "C" - CADASTRO NACIONAL DA PESSOA JURÍDICA}

1) Cadastro Nacional de Pessoa Jurídica - CNPJ (Privado)

\section{REPÚBLICA FEDERATIVA DO BRASIL \\ CADASTRO NACIONAL DA PESSOA JURÍDICA}

NOMERO DE INSCRICৃÁO

84.596.170/0001-70

COMPROVANTE DE INSCRIÇÃO E DE SITUAÇÃO CADA STRAL

DATA DEABERTURA $02 / 04 / 1993$

MATRIZ

NOME EMPRESARIAL

CENTRO DE EN SINO SAO LUCAS LTDA

TITULO DO ESTABELECIMENTO (NOME DE FANTASIA)

FACULDADE SAO LUCAS

CODIGO E DESCRIÇĂO DA.ATMDADE ECONOMICA PRINCIPAL

85.32-5-00 - Educação superior - graduação e pós-graduação

CODIGO E DESCRIÇĂO DAS ATMDADES ECONOMICAS SECUNDARIAS

Não informada

CODIGO E DESCRICLAOO DANATUREZA JURIDICA

206-2 - SOCIEDADE EMPRESARIA LIMITADA

LOGRADOURO

R ALEXANDRE GUIMARAES

$\begin{array}{ll}\text { CEP } & \text { GAIRROIDISTRITO } \\ 76.804-373 & \text { AREAL }\end{array}$

ENDEREÇO ELETRONICO

legalizacao@atual-rnc.com.br

NUMERO COMPLEMENTO 1927

MUNICIPIO

PORTO VELHO

ENTE FEDERATMO RESPONSAVEL (EFR)

TELEFONE
(69) 3224-5510

STUACËO CADASTRAL

ATIVA

DATA DA SITUAÇ,ÁO CADASTRAL

MOTMO DE SITUAC̨ĂO CADASTRAL 24/09/2005 
2) Cadastro Nacional de Pessoa Jurídica - CNPJ (Público)

\section{REPÚBLICA FEDERATIVA DO BRASIL CADASTRO NACIONAL DA PESSOA JURÍDICA}

NOMERO DE INSCRIÇ.AOO 08.240.695/0001-90

COMPROVANTE DE INSCRIÇÃO E DE SITUAÇÃO CADASTRAL
DATADEABERTURA. 13/07/2006

NOME EMPRESARIAL

NOME EMPRESARLAL
UNIVERSIDADE ESTADUAL DE RORAIMA

TITULO dO ESTABELECIMENTO (NOME DE FANTASIA)

CODIGO E DESCRIÇ,AO DA.ATMDADE ECONOMICA PRINCIPAL

85.32-5-00 - Educação superior - graduação e pós-graduação

CODIGO E DESCRICLÁO DAS ATMDADES ECONOMICAS SECUNDARIAS

85.99-6-99 - Outras atividades de ensino não especificadas anteriormente

85.33-3-00 - Educação superior - pós-graduação e extensão

CODIGO E DESCRIÇÁLO DANATUREZA JURIDICA.

114-7 - FUNDACAO PUB. DE DIREITO PUB. EST. OU DO DF

LOGRADOURO

R SETE DE SETEMBRO

NOMERO COMPLEMENTO

CEP BAIRROIDISTRITO

69.306-530 CANARINHO

ENDEREÇO ELETRONICO

ENTE FEDERATMO RESPONSAVEL (EFR)

RR

SITUAÇAOO CADASTRAL

ATIVA

TELEFONE

(95) $3224-8455$

MOTMO DE SITUACEALO CADASTRAL

DATA DASITUACËO CADASTRAL 13/07/2006 


\section{ANEXO "D" - DOCUMENTO DO GOVERNO DE BRASÍLIA AUTORIZANDO O ACESSO ÀS DEPENDÊNCIAS DAS ESCOLAS SEM IDENTIFICAÇÃO DAS MESMAS}

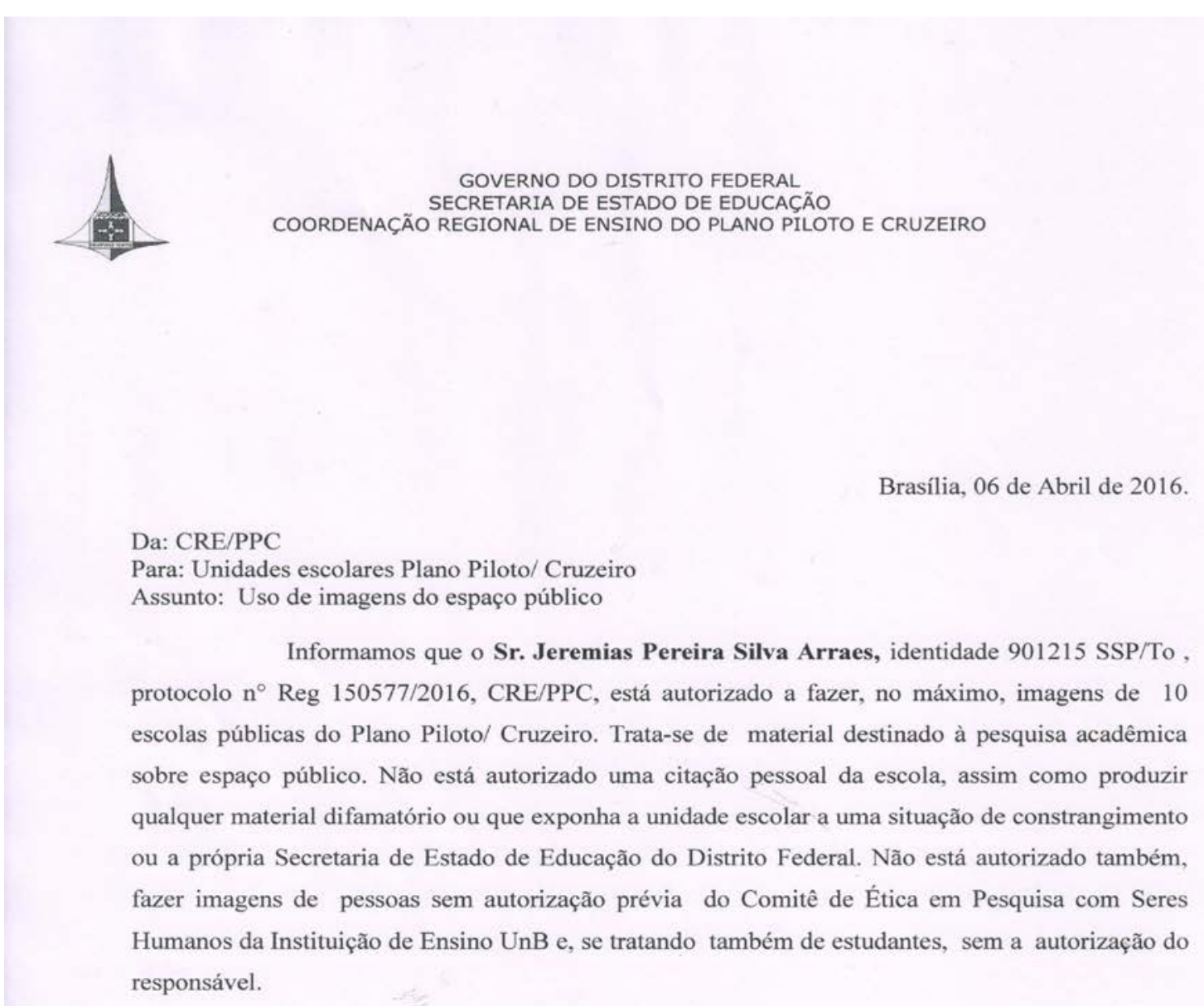

Atenciosamente,

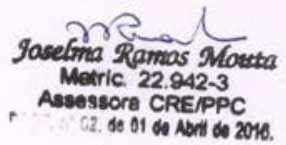




\section{ANEXO "E" - ESCOLAS PÚBLICAS APTAS A RECEBEREM SELEÇÕES PÚBLICAS CONFORME CRITÉRIOS ESTABELECIDOS PELO CESPE/CEBRASPE}

\begin{tabular}{|c|c|c|c|c|c|c|}
\hline Quantidade & Local & RA & Escola & Turma & Matrícula & Média M/T \\
\hline 1 & CRE - PLANO PILOTO-CRUZEIRO & RA - BRASÍLIA & 53000927 - CEF POLIVALENTE & 17 & 621 & 36,53 \\
\hline 2 & CRE - PLANO PILOTO-CRUZEIRO & RA - BRASÍLIA & 53000986 - CEM PAULO FREIRE & 14 & 485 & 34,64 \\
\hline 3 & CRE - PLANO PILOTO-CRUZEIRO & RA - BRASÍLIA & 53001010 - CEM ASA NORTE - CEAN & 12 & 479 & 39,92 \\
\hline 4 & CRE - PLANO PILOTO-CRUZEIRO & RA - BRASÍLIA & 53001036 - CEM ELEFANTE BRANCO & 24 & 958 & 39,92 \\
\hline 5 & CRE - PLANO PILOTO-CRUZEIRO & RA - BRASÍLIA & 53001044 - CED GISNO MÉDIO & 21 & 625 & 29,76 \\
\hline 6 & CRE - PLANO PILOTO-CRUZEIRO & RA - BRASÍLIA & 53001044 - CED GISNO FUNDAMENTAL & 6 & 146 & 24,33 \\
\hline 7 & CRE - PLANO PILOTO-CRUZEIRO & RA - BRASÍLIA & 53001206 - CEM SETOR LESTE & 22 & 828 & 37,45 \\
\hline 8 & CRE - PLANO PILOTO-CRUZEIRO & RA - BRASÍLIA & 53001214 - CEM SETOR OESTE & 13 & 477 & 36,69 \\
\hline 9 & CRE - GAMA & RA - GAMA & 53002474 - CEF GESNER TEIXEIRA & 20 & 628 & 31,40 \\
\hline 10 & CRE - GAMA & RA - GAMA & 53002482 - CED 08 DO GAMA MÉDIO & 18 & 650 & 36,11 \\
\hline 11 & CRE - GAMA & RA - GAMA & 53002482 - CED 08 DO GAMA FUNDAMENTAL & 18 & 569 & 31,61 \\
\hline 12 & CRE - GAMA & RA - GAMA & 53002504 - CEF 05 DO GAMA & 18 & 596 & 33,11 \\
\hline 13 & CRE - GAMA & RA - GAMA & 53002512 - CEF 08 DO GAMA & 14 & 450 & 32,14 \\
\hline 14 & CRE - GAMA & RA - GAMA & 53002547 - CEF 11 DO GAMA & 12 & 393 & 32,75 \\
\hline 15 & CRE - GAMA & RA - GAMA & 53002563 - CED 07 DO GAMA & 18 & 558 & 31 \\
\hline 16 & CRE - GAMA & RA - GAMA & 53002580 - CEM 01 DO GAMA & 27 & 1.034 & 38,3 \\
\hline 17 & CRE - GAMA & RA - GAMA & 53002598 - CEM 02 DO GAMA & 28 & 1.053 & 37,61 \\
\hline 18 & CRE - GAMA & RA - GAMA & 53002601 - CEM 03 DO GAMA & 18 & 684 & 38 \\
\hline 19 & CRE - GAMA & RA - GAMA & 53002610 - CED 06 DO GAMA MÉDIO & 20 & 637 & 31,85 \\
\hline 20 & CRE - GAMA & RA - GAMA & 53002610 - CED 06 DO GAMA FUNDAMENTAL & 24 & 553 & 23,04 \\
\hline 21 & CRE - GAMA & RA - GAMA & 53003004 - CEF 03 DO GAMA & 18 & 557 & 30,94 \\
\hline 22 & CRE - TAGUATINGA & RA - TAGUATINGA & 53003446 - CEF 03 DE TAGUATINGA & 17 & 561 & 33 \\
\hline 23 & CRE - TAGUATINGA & RA - TAGUATINGA & 53003454 - CEF 04 DE TAGUATINGA & 11 & 355 & 32,27 \\
\hline
\end{tabular}




\begin{tabular}{|c|c|c|c|c|c|c|}
\hline 24 & CRE - TAGUATINGA & RA - TAGUATINGA & 53003470 - CEF 08 DE TAGUATINGA & 13 & 436 & 33,54 \\
\hline 25 & CRE - TAGUATINGA & RA - TAGUATINGA & 53003489 - CEF 09 DE TAGUATINGA & 14 & 454 & 32,43 \\
\hline 26 & CRE - TAGUATINGA & RA - TAGUATINGA & 53003500 - CEF 11 DE TAGUATINGA & 15 & 467 & 31,13 \\
\hline 27 & CRE - TAGUATINGA & RA - TAGUATINGA & 53003519 - CEF 12 DE TABGUATINGA & 16 & 501 & 31,31 \\
\hline 28 & CRE - TAGUATINGA & RA - TAGUATINGA & 53003527 - CEF 14 DE TAGUATINGA & 15 & 532 & 35,47 \\
\hline 29 & CRE - TAGUATINGA & RA - TAGUATINGA & 53003535 - CEF 15 DE TAGUATINGA & 15 & 471 & 31,40 \\
\hline 30 & CRE - TAGUATINGA & RA - TAGUATINGA & 53003586 - CEM 03 DE TAGUATINGA & 19 & 755 & 39,74 \\
\hline 31 & CRE - TAGUATINGA & RA - TAGUATINGA & 53003594 - CED 04 DE TAGUATINGA MÉDIO & 15 & 471 & 31,40 \\
\hline 32 & CRE - TAGUATINGA & RA - TAGUATINGA & 53003594 - CED 04 DE TAGUATINGA FUNDAMENTAL & 4 & 128 & 32 \\
\hline 33 & CRE - TAGUATINGA & RA - TAGUATINGA & 53003608 - CED 05 DE TAGUATINGA MÉDIO & 20 & 700 & 35 \\
\hline 34 & CRE - TAGUATINGA & RA - TAGUATINGA & 53003608 - CED 05 DE TAGUATINGA FUNDAMENTAL & 14 & 437 & 31,21 \\
\hline 35 & CRE - TAGUATINGA & RA - TAGUATINGA & 53003616 - CED 06 DE TAGUATINGA & 20 & 704 & 35,20 \\
\hline 36 & CRE - TAGUATINGA & RA - TAGUATINGA & 53003624 - CED 07 DE TAGUATINGA MÉDIO & 14 & 553 & 39,50 \\
\hline 37 & CRE - TAGUATINGA & RA - TAGUATINGA & 53003624 - CED 07 DE TAGUATINGA FUNDAMENTAL & 3 & 86 & 28,67 \\
\hline 38 & CRE - TAGUATINGA & RA - TAGUATINGA & 53003632 - CEM AVE BRANCA & 28 & 1.080 & 38,57 \\
\hline 39 & CRE - TAGUATINGA & RA - TAGUATINGA & 53003683 - CEM TAGUATINGA NORTE & 18 & 736 & 40,89 \\
\hline 40 & CRE - TAGUATINGA & RA - TAGUATINGA & 53003691 - CEM EIT & 19 & 718 & 37,79 \\
\hline 41 & CRE - TAGUATINGA & RA - TAGUATINGA & 53004280 - CEF 16 DE TAGUATINGA & 10 & 316 & 31,60 \\
\hline 42 & CRE - BRAZLANDIA & RA - BRAZLANDIA & 53005015 - CEM 01 DE BRAZLANDIA & 18 & 696 & 38,67 \\
\hline 43 & CRE - BRAZLANDIA & RA - BRAZLANDIA & 53005023 - CED 02 DE BRAZLANDIA MÉDIO & 3 & 117 & 39 \\
\hline 44 & CRE - BRAZLANDIA & RA - BRAZLANDIA & 53005023 - CED 02 DE BRAZLANDIA FUNDAMENTAL & 19 & 594 & 31,26 \\
\hline 45 & CRE - BRAZLANDIA & RA - BRAZLANDIA & 53005090 - CEF 02 DE BRAZLANDIA & 17 & 565 & 33,24 \\
\hline 46 & CRE - SOBRADINHO & RA - SOBRADINHO & 53005341 - CED 03 DE SOBRADINHO MÉDIO & 15 & 558 & 37,2 \\
\hline 47 & CRE - SOBRADINHO & RA - SOBRADINHO & 53005341 - CED 03 DE SOBRADINHO FUNDAMENTAL & 25 & 782 & 31,28 \\
\hline 48 & CRE - SOBRADINHO & RA - SOBRADINHO & 53005350 - CEF 03 DE SOBRADINHO & 17 & 548 & 32,24 \\
\hline 49 & CRE - SOBRADINHO & RA - SOBRADINHO & 53005368 - CEF 04 DE SOBRADINHO & 19 & 574 & 30,21 \\
\hline 50 & CRE - SOBRADINHO & RA - SOBRADINHO & 53005376 - CEF 05 DE SOBRADINHO & 14 & 479 & 34,21 \\
\hline 51 & CRE - SOBRADINHO & RA - SOBRADINHO & 53005392 - CED FERCAL MÉDIO & 6 & 199 & 33,17 \\
\hline
\end{tabular}




\begin{tabular}{|c|c|c|c|c|c|c|}
\hline 52 & CRE - SOBRADINHO & RA - SOBRADINHO & 53005392 - CED FERCAL FUNDAMENTAL & 7 & 218 & 31,14 \\
\hline 53 & CRE - SOBRADINHO & RA - SOBRADINHO & 53005406 - CEF QUEIMA LENÇOL & 17 & 549 & 32,29 \\
\hline 54 & CRE - SOBRADINHO & RA - SOBRADINHO & 53005565 - CEM 01 DE SOBRADINHO & 24 & 920 & 38,33 \\
\hline 55 & CRE - SOBRADINHO & RA - SOBRADINHO & 53005473 - CED 02 DE SOBRADINHO MÉDIO & 17 & 621 & 36,53 \\
\hline 56 & CRE - SOBRADINHO & RA - SOBRADINHO & 53005473 - CED 02 DE SOBRADINHO FUNDAMENTAL & 8 & 274 & 34,25 \\
\hline 57 & CRE - PLANALTINA & RA - PLANALTINA & 53005961 - CEF 03 DE PLANALTINA & 16 & 483 & 30,19 \\
\hline 58 & CRE - PLANALTINA & RA - PLANALTINA & 53005996 - CEF 01 DE PLANALTINA & 18 & 638 & 35,44 \\
\hline 59 & CRE - PLANALTINA & RA - PLANALTINA & 53006003 - CEF 02 DE PLANALTINA & 20 & 736 & 36,80 \\
\hline
\end{tabular}




\section{ANEXO “F” - RELATÓRIO TÉCNICO}

\section{INTRODUÇÃO}

A prévia aprovação em concurso público para investidura em cargo ou emprego público no Brasil, com algumas exceções, tornou-se obrigatória com o advento da Constituição Federal (CF) de 1988 (AGLANTZAKIS, 2003). Com a exigência de concurso público para ingresso no serviço público e o aumento da população brasileira, cresceu também a demanda pelos serviços públicos e a estrutura administrativa teve que acompanhar a evolução com a criação de mais instituições públicas e, consequentemente, o aumento de seleções públicas para contratação de pessoal.

Do mesmo modo, a população de servidores públicos em todos os poderes da União, dos Estados, dos Municípios e do Distrito Federal também cresceram. Tal evolução no quadro de servidores públicos gerou um aumento significativo nos concursos públicos e, consequentemente, no número de bancas organizadoras de concursos/seleções públicas. Isto posto, somente o CESPE/CEBRASPE realizou, de 2009 a 2014, 320 seleções públicas no Brasil, destacando-se como uma das maiores bancas examinadoras do país (PATI, 2013).

Por conseguinte, o aumento do número de concursos públicos em toda esfera de governo demandaram a criação de muitas instituições especializadas na organização de seleção pública, de modo que, nos últimos anos, conforme o site Concursos no Brasil (2015), já se ultrapassou a marca de 590 bancas organizadoras de concursos registradas no País. 
Desse modo, o mercado "concurso público" tem crescido desordenadamente no Brasil e, como as casas legislativas têm discutido sobre a matéria com o objetivo de estabelecer normas gerais para realização dos certames, faz-se necessário estudar sobre a logística para realização desses eventos, principalmente quanto a existência de espaço público disponível, que possuam as mesmas características dos espaços privados atualmente contratados pelas bancas organizadoras, para que tais espaços também possam ser aproveitados nas seleções públicas.

A frequente seleção das mesmas instituições de ensino privadas e a baixa procura pelos espaços públicos podem despertar alguns questionamentos, como, por exemplo: qual seria o critério adotado pelo CESPE/CEBRASPE para locar um espaço físico? Vale destacar que, conforme o Censo Escolar 2014 (INEP, 2014), a utilização de instituições públicas para a realização de concursos públicos ao invés de privadas, pode ser uma forma das referidas instituições arrecadarem recursos e otimizar seus espaços em períodos ociosos, haja vista que tais instituições, mesmo quando não utilizadas, como, por exemplo, nos finais de semanas, geram custos (que fazem parte das despesas totais com o ensino no País) para o Estado.

Além disso, os estudos que abordam o concurso público no Brasil, como o de Fontainha et al. (2014), estão voltados para os métodos de seleção, o sistema de arrecadação com as taxas de inscrições para participação na seleção ou sobre o mercado milionário de cursos preparatórios que foi instaurado no país. Logo, é necessário que haja também estudos quanto à logística para execução dos concursos públicos, pois a realização do evento também demanda uma enorme alocação de esforços e recursos que devem ser investigados. 
Por isso, o objetivo do estudo é investigar se há espaço público disponível no Distrito Federal para a realização de concursos públicos que atendam os critérios mínimos estabelecidos pelo CESPE/CEBRASPE para contratação, uma vez que tal possibilidade, pode acarretar na redução do escopo da contratação, na otimização do gasto público, bem como abre a possibilidade da instituição pública na arrecadação de valores com a locação do seu espaço em períodos ociosos. Logo, havendo a possibilidade de locação de espaço público para a realização de concurso, trata-se de milhões de reais injetados nas instituições de ensino públicas do país.

\subsection{OBJETIVOS}

O presente estudo buscou analisar se as instituições de ensino público no Distrito Federal podem substituir os espaços privados utilizados pelo CESPE/CEBRASPE para a realização de concurso público. Em especial buscou-se: [1] Descrever os critérios e características utilizados pelo CESPE para definir a contratação/locação de espaço privado para a realização de concurso público no período de 2009 a 2014; [2] Identificar as instituições públicas e privadas do Distrito Federal utilizadas pelo CESPE para realização de concurso público e comparar os gastos com a locação de espaço físico para realização desses eventos, entre esses entes, no período de 2009 a 2014; [3] Demonstrar a evolução dos recursos captados pelo CESPE e os gastos com locação de espaço físico para realização de concurso público no período de 2009 a 2014; [4] Descrever as instituições públicas de ensino com os critérios e características utilizadas pelo CESPE para definir a contratação/locação de espaço para concurso público no Distrito Federal; e [5] 
Apresentar a forma de contratação, a modalidade de licitação e as justificativas do CESPE para locação de espaço físico para realização de concurso público no período de 2009 a 2014.

\subsection{ESTRUTURA DA DISSERTAÇÃO}

A dissertação foi dividida em 6 capítulos. No capítulo inicial foram definidos a formulação do problema, os objetivos, a justificativa e o Locus da pesquisa. No segundo capítulo discute-se o conceito de público e privado, bem como a forma de locação do espaço público. Aborda-se ainda um breve histórico sobre o concurso público no país e o seu crescimento nos últimos anos. Finaliza-se o capítulo com uma abordagem sobre a qualidade do gasto público na realização dos concursos públicos. O capítulo três expõe como a pesquisa foi conduzida, apresentando o percurso metodológico, dando ênfase ao estudo exploratório e descritivo e ao modelo qualitativo de coleta de dados e análise dos dados. No quarto capítulo narrase os resultados obtidos com a pesquisa, descrevendo as característica dos espaços privados locados pelo CESPE, a evolução dos recursos recebidos pelo CESPE no período de 2009 a 2014, o comparativo das locações entre entes públicos e privados e a descrição das instituições públicas que atendem os mesmos critérios das instituições privadas locadas pelo CESPE neste período. O capítulo seguinte apresenta as conclusões sobre a pesquisa e no capítulo seis define as recomendações que o CESPE deve tomar para que possa cumprir as recomendações dos órgãos de controle e analisar a viabilidade da utilização dos espaços públicos para realização dos concursos públicos. 


\subsection{REFERENCIAL TEÓRICO}

O referencial teórico da pesquisa foi organizado abordando, em um primeiro momento, o conceito de público e privado e a forma de locação do espaço público. Em seguida, tem-se a questão do concurso público como modalidade de licitação para o provimento de cargos e funções públicas no Brasil. Por fim, conceitua-se a qualidade no gasto público com base nas despesas com a locação de espaço físico realizadas por meio de dispensa de licitação.

O Estudo traz a ideia de público e privado é com debate desde a Grécia antiga, tendo mudado de significado ao longo do tempo e tornado o debate cada vez mais intenso, devido à complexidade das sociedades no mundo moderno. Para Pinto e Costa (2015, p. 312), o histórico estatal brasileiro é vestido justamente pelas dificuldades de distinguir os interesses privados de interesses públicos; ou seja, "observa-se, sobretudo na herança do período colonial e ao longo da república velha, a caracterização de um modelo patrimonialista, em que se confundindo o público e o privado, havia forte presença de corrupção, clientelismo e nepotismo".

Para Bandeira de Mello (1975), o público e o privado assumem conotações diversificadas, dependendo do olhar que lhes é lançado. Contudo, quando caracterizadas no jurídico-formal, tais termos se vinculam a explicitação do regime jurídico.

Neves (2008) destaca 02 (duas) questões primordiais a serem abordadas sobre a locação de espaço público, quais sejam: 1) qual a forma administrativa de utilização do espaço público; e, 2) se há ou não a necessidade de licitação para tal uso. Neste sentido, é preciso entender de que forma os espaços públicos poderiam ser utilizados por terceiros, bem como qual seria a forma correta da contratação. 
O estudo apresenta a forma de permissão de uso como a adequada para utilização do espaço público para realização de concurso público. Modo pelo qual a Administração Pública autorizaria um ente privado a usufruir do bem público, atendendo interesse público e que poderia ser gratuito ou oneroso para o solicitante, no caso, a banca organizadora. Por isso, utilizar um espaço público para realização de concurso público reporta ao princípio da eficiência, conforme é destacado por Alexandre de Moraes (2008, p. 326) e Di Pietro (2006, p. 98). Pois, a maioria das instituições de ensino público encontra-se fechadas aos finais de semana, justamente o período que as bancas organizadoras costumam utilizar para a realização de seus eventos. Contudo, no ordenamento jurídico, não há obrigatoriedade de utilização de espaço público para a realização de concurso público. Ou seja, algumas instituições públicas, desde que atendido os critérios mínimos para a realização do evento, poderiam estar arrecadando recursos, locando suas estruturas nos períodos ociosos e garantindo a melhor utilização dos recursos públicos.

Ainda sim, ofertar a possibilidade de uma instituição pública arrecadar recursos por meio de locação de espaço e vincular tais recursos ao investimento em infraestrutura, poderia contribuir com a qualidade do ensino, pois, segundo Passador, Yoshimoshi e Artoni (2011), "acredita-se que as escolas que possuem os piores desempenhos têm um conjunto maior de problemas diferenciando-se das demais escolas", uma vez que se tem aí a correlação da infraestrutura com a qualidade do ensino.

É bem verdade que quando a Administração Pública pretende adquirir ou alugar imóvel para atender suas finalidades precípuas, ela pode dispensar a licitação e contratar diretamente com o locador, conforme dispõe o art. 24 , inc. X, da Lei n. 
8.666/1993. Porém, tal contratação não é totalmente livre. Para contratar diretamente exige-se que o imóvel a ser locado seja realmente indispensável para Administração Pública, em razão das necessidades de instalação e localização.

O estudo ainda expõe a percepção de José dos Santos Carvalho Filho (2009, p. 249), Jorge Ulisses Jacoby Fernandes (2000, p. 388) e Marçal Justen Filho (2008, p. 308) quanto a contratação direta prevista no art. 24, inc. X da Lei n. 8.666/1993, esclarecendo que não configuraria caso de dispensa de licitação, mas, na prática, hipótese de inexigibilidade.

O estudo aborda, ainda, a necessidade de regulamentação, pois apesar de a legislação vigente tratar da modalidade concurso, ainda resta normatizar muitos procedimentos desta, como, por exemplo, a forma de contratação de bancas organizadoras (feita por dispensa de licitação), valores de taxas de inscrição (não obrigatoriedade de o valor da taxa está associado ao valor do salário do respectivo cargo), locais para a realização dos certames (não estabelece critérios de utilização de espaço, nem prioriza a realização dos certames em espaço público), entre outros aspectos.

A qualidade do gasto público também é discutida no estudo, pois está envolvida no concurso público, desde a contratação da banca examinadora até a realização do evento. Pois, a seleção pública envolve um grande volume de recursos públicos que devem ser gastos com transparência e responsabilidade.

Os órgãos públicos que não possuem suas próprias bancas examinadoras, com estrutura, pessoal e competência necessária para realizar as seleções públicas da sua própria casa, em geral, realizam as contratações de outras bancas por meio de contratações diretas, sem licitação, alegando inviabilidade de competição para execução dos serviços. 
A pesquisa apresenta o gasto com a locação de espaço do CESPE/CEBRASPE, de 2009 a 2014, apurados pelo SIAFI, com análise de 29.372 empenhos para a locação de espaço físico. Sendo que todas as locações foram feitas por meio de dispensa de licitação, com embasamento legal no art. 24, incs. I, II e X, da Lei n. 8.666/1993.

Ressalta-se no estudo a questão da modalidade de licitação utilizada pelo CESPE/CEBRASPE para realizar a contratação dos espaço público, pois a contratação direta de banca examinadora, por meio de inexigibilidade de licitação, em muitos casos, desconsidera completamente o princípio da economicidade, logo, a arrecadação dos valores referente às inscrições dos candidatos não chega nem próximo ao que se gasta na contratação dos serviços. Neste caso, não há um equilíbrio no que se arrecada e o que se gasta e, consequentemente, não qualidade no gasto público.

Do mesmo modo, a instituição pública contratada para a realização da seleção pública não pode, de qualquer forma, locar imóveis sem atender aos critérios e hipóteses previstas em Lei. Pois, aí também haveria o comprometimento da eficiência do gasto público. Tal situação é observada justamente quando não há o aproveitamento dos espaços públicos para a realização de concursos públicos, pois, se existem espaços públicos disponíveis, por que eles não são utilizados em sua totalidade nas seleções?

A qualidade do gasto está correlacionada com a gestão dos custos. Logo, quando uma instituição pública loca um determinado espaço para a realização de um evento, ela deve preocupar-se com uma pesquisa de mercado que comprove que o local contratado atenda as necessidades da instituição e possua um preço justo, compatível com o preço médio do mercado. Portanto, a contratação direta, 
principalmente quando utilizado os argumentos da inexigibilidade (art. 25, Lei n. 8.666/1993), caracterizado pela inviabilidade de competição, correm risco de aumento dos custos, pois não há demonstrativo para se comparar o preço de mercado.

\section{METODOLOGIA}

Para que os resultados fossem alcançados, empregaram-se diversas fontes de pesquisa. De modo específico, foram analisadas as despesas com locação de espaço físico nos processos de contratação do CESPE/CEBRASPE como organizador do concurso público. Garantido pela Lei n. 12.527/2011, Lei de Acesso a Informação (LAI), também foi realizado análise processual para a verificação dos contratos, empenhos e pagamentos. Contudo, além da análise contratual, verificaram-se os dados de arrecadação, empenho e pagamentos realizados por aquela Banca Examinadora de 2009 à 2014, por meio do Portal da Transparência e do Sistema Integrado de Administração Financeira do Governo Federal (SIAFI).

Quanto aos meios, a pesquisa foi de cunho bibliográfico, de campo e documental. E executou-se uma investigação de campo, porque tem-se aqui uma “investigação empírica realizada no local onde ocorreu um fenômeno ou que dispõe de elementos para explicá-lo" (VERGARA, 2005, p. 45), haja vista que foram coletados dados primários nas dependências do CESPE/CEBRASPE. Ainda sim, foram efetuadas 10 (dez) visitas às instituições de ensino no Distrito Federal, para avaliar a capacidade real destacada pelo Instituto Nacional de Estudos e Pesquisas Educacionais Anísio Teixeira (INEP) e a qualidade da infraestrutura. 
Quanto aos fins, devido às poucas informações e o pouco conhecimento acumulado e sistematizado do problema, efetuou-se uma investigação exploratória e descritiva; exploratória porque embora os concursos públicos tenham sido tema de diversas pesquisas, não se verificou estudos que abordem a locação de espaço público para a realização de concurso. E descritiva porque descreveu percepções, expectativas e sugestões para utilização do espaço público em concurso.

Em um primeiro momento foram analisados os dados apurados por meio de documentos e fontes de dados de arquivos. Os dados coletados foram dos últimos 06 (seis) anos de atividades exercidas pelo CESPE/CEBRASPE, especificamente os exercícios de 2009, 2010, 2011, 2012, 2013 e 2014. A coleta se deu principalmente naquela Banca Examinadora, por meio de consulta telefônica, visita a sítios eletrônicos, obtenção e análise de relatórios específicos, mapas e figuras, análise processual das contratações.

Para complementar e aprofundar a discussão do problema de pesquisa, foram realizadas 03 (três) entrevistas, sendo que a primeira de forma aberta e as outras 02 (duas) de forma semiestruturadas com 04 (quatro) representantes da instituição envolvidos na fase de seleção e contratação dos espaços privados utilizados na realização dos concursos públicos.

O estudo analisou toda despesa de locação de imóveis do CESPE/CEBRASPE no período supramencionado, com mais de 68 mil lançamentos contábeis, entre Nota de Sistema (NS), Nota de Empenho (NE) e Ordem Bancária (OB), com uma média de cerca de 11.400 lançamentos contábeis anuais, vinculados à quase 04 (quatro) mil credores diferentes. 
Por fim, as entrevistas foram essenciais para coletar os dados que não foram possíveis por meio de pesquisa bibliográfica e de observação. Inicialmente, as entrevistas foram realizadas de forma aberta, atendendo a finalidade exploratória e que, conforme o desenvolvimento, foram alteradas posteriormente para atender os objetivos propostos. Na entrevista exploratória foi possível entender o processo de reestruturação vivenciado pelo CESPE, com o encerramento de suas atividades e a transformação em uma OS sem fins lucrativos: o CEBRASPE. Posteriormente deuse a entrevista estruturada, ou formalizada, desenvolvida a partir de uma relação fixa de perguntas, cuja ordem e redação permaneceram invariáveis para todos os entrevistados (GIL, 1999).

\subsection{ANÁLISE DOS DADOS}

O tratamento especializado dos dados se deu de modo qualitativo, fazendo uso de métodos estatísticos descritivos, e por meio de análise descritiva das informações, para a apresentação dos dados de forma estruturada. Foi utilizado o método da estatística descritiva com o objetivo de descrever, analisar e interpretar os dados numéricos da amostra selecionada, resumindo essas principais características por meio de tabelas, gráficos e resumos numéricos (FONSECA; MARTINS, 1996, p. 101).

Para a obtenção de maior familiaridade junto ao problema de pesquisa, fizeram-se entrevistas com pessoas que estiveram envolvidas com as práticas do problema pesquisado. Diante do exposto, a presente pesquisa teve por intenção descrever as situações que envolvem desde a arrecadação dos últimos anos do CESPE/CEBRASPE às despesas com alocação de espaço físico e suas 
características. Por isso, a técnica utilizada para o tratamento dos dados foi a estatística descritiva.

No desenvolvimento da pesquisa, apresentaram-se dificuldades referentes à coleta de dados, uma vez que a análise processual das contratações de espaço físico dependeram de autorização do representante máximo da instituição organizadora dos concursos, no caso, o CESPE/CEBRASPE. Além disso, aparentemente, após as primeiras reuniões, a pesquisa foi vista pelos gerentes da instituição como uma forma de fiscalização da instrução processual, na qual poderia acarretar em descoberta de erros ou que prejudicasse o ramo do negócio do CESPE/CEBRASPE, assim como justificado em respostas por meio de e-mail, o que acabou por dificultar ainda mais a obtenção dos dados desejados.

Ademais, algumas das informações solicitadas na entrevista semiestruturada, como, por exemplo, àquelas referentes ao item 12 do questionário, não foram respondidas, pois, apesar de já haver autorização do Diretor do CESPE, o coordenador alegou que tais informações precisariam de autorização da Direção do CESBRASPE. Em resumo, a situação de autorização de ambos os diretores sempre foi uma barreira para a conclusão do presente estudo, o que demandou um longo tempo na aquisição das respostas. Ao passo que, outras informações como, por exemplo, àquelas pertinentes aos itens 5 e 10, a princípio, não foram respondidas com a justificativa de que estas não eram públicas e faziam parte do negócio de trabalho do CESPE/CEBRASPE, e que sua publicidade poderia atrapalhar a competitividade da organização, bem como a assinatura de futuros contratos.

Salientam-se também as dificuldades encontradas para 0 acesso às dependências das escolas de ensino básico (Médio e Fundamental), pois, mesmo os estabelecimentos sendo públicos, por diversas vezes, o pesquisador foi impedido de 
tirar fotos das salas das instituições. Quando da autorização para o acesso às dependências das instituições públicas, desde a primeira solicitação à resposta final, passaram-se mais de 13 meses, com documentos enviados aos diretores, aos coordenadores regionais e à Secretaria de Estado de Educação do Distrito Federal (SEDF), e que, mesmo após autorização da visita as dependências, não foi autorizada a divulgação dos nomes e das localidades das escolas.

\section{RESULTADOS GERAIS}

A pesquisa identificou que os critérios para locação do espaço são basicamente definidos pela infraestrutura, localização e capacidade por instituição. Porém, apesar de que o CESPE/CEBRASPE possuir um cadastro com todas as instituições públicas e privadas do DF, bem como as informações necessárias para locação do espaço, este centro não possui um check list (ou documento similar de conferência/controle) próprio para identificar as características mínimas da instituição que poderão ser utilizada, nem tão pouco possui um modelo exato de estabelecimento que poderá ser locado. Não há um perfil exato de espaço físico mínimo que possa ser locado. O espaço é locado de acordo com a demanda do evento, sempre com análise do custo/benefício, podendo variar o tipo de espaço locado conforme as especificidades da região.

Conforme a pesquisa, foi possível observar que o CESPE/CEBRASPE não possui um critério definido ou normatizado para selecionar um espaço físico para a locação de um evento qualquer. Pois, apesar de possuir uma lista com capacidade das instituições públicas e privadas do Brasil e do Distrito Federal, não se tem um 
documento que especifique as características básicas ou mínimas que a instituição deve atender para que seja contratada.

Mesmo não havendo critério para a locação de um espaço, foi possível identificar, por meio dos gastos com a locação de espaço, as instituições públicas e privadas do Distrito Federal que são utilizadas pelo CESPE/CEBRASPE. Contudo, constatou-se que além dessas, houve pagamento, também, à pessoa física.

A crescente demanda por concurso público e a arrecadação do CESPE/CEBRASPE ratificam a necessidade de uma legislação específica para regulamentar tanto as seleções como a forma de contratação das bancas organizadoras. Pois, mesmo com a mudança das características do governo atual que optou pelo fortalecimento do quadro estatal -, as seleções públicas perdurarão na Administração Pública devido a obrigatoriedade estabelecida na Carta Magna de 1988.

Por meio dos gastos com locação de espaço físico, constatou-se que o CESPE/CEBRASPE prioriza a contratação do espaço privado ao invés do público, mesmo que este possua espaço similar ao contratado. Ressalta-se aqui a verificação de um processo discricionário do Centro para a seleção dos locais onde serão realizados seus eventos, com a justificativa de ora por exigências dos clientes, ora por logística.

Verificou-se, ainda, no estudo, que existem instituições públicas que cedem o espaço para realização de seleções públicas sem nenhum custo para o CESPE/CEBRASPE, que, por sua vez, disponibiliza para estas uma espécie de "kit de material de limpeza", como forma de permuta pela utilização do espaço. Por outro lado, também há instituições públicas que locam seus espaços e recebem recursos financeiros pela cessão de espaço, confirmando o que fora antecipado como 
verdade provisória nas hipóteses diretrizes. Todavia, no caso do Distrito Federal, os valores pagos foram efetuados em nome da Secretaria de Estado de Educação do Distrito Federal (SEDF) e, por esse motivo, não se sabe se esses recursos chegaram às instituições públicas locadas.

O Distrito Federal possui espaço físico público que atende as exigências mínimas do CESPE/CEBRASPE para a locação de espaço para eventos diversos, bem como possui instituições de ensino com características similares aos espaços privados. Conforme os resultados aqui logrados, atualmente, pelo menos 164 escolas do ensino básico com capacidade de mais de 167 mil alunos estão aptas a serem utilizadas em seleções públicas, além das instituições de Ensino Superior e Técnico, como, por exemplo, a Universidade de Brasília (UnB) e o Instituto Federal de Brasília (IFB).

Por fim, devido à oferta de espaço público ser similar nas instituições, tornar obrigatório, por meio de legislação específica, a utilização de espaço público para realização de concurso público, pode trazer inúmeros benefícios à sociedade, por meio da melhoria da educação, pois, estimular a competição entre as instituições públicas para locar seus espaços, além de ser inovadora, faria com que estas zelassem pelo seu patrimônio e buscassem sempre melhorá-lo; ou seja, quanto melhor suas estruturas, mais chance teriam de ser locadas.

Apesar de não ter sido comprovado tal situação no estudo, há indícios de que a competitividade é plenamente viável na Administração Pública, contrariando a regra atual e seguindo um novo caminho: o da Administração Pública gerencial ou nova gestão pública (new public management). 


\section{RECOMENDAÇÕES}

Tendo em vista a crescente demanda por concursos públicos no Brasil, as linhas que se seguiram observaram que algumas situações outrora apresentadas carecem de pesquisa profunda, uma vez que, apesar do vasto acervo de material bibliográfico sobre a locação de espaço público e métodos de seleção pública, pouco se viu sobre a logística e, principalmente, quanto à locação de espaços para realização de concurso público. Além disso, há uma serie de entendimentos jurídicos quanto à forma de locação de espaço privado por agente público, quando há tempo, a Administração Pública interpreta a dispensa de licitação com a inexigibilidade, onde esta carece de inviabilidade de competição.

Logo, nesta perspectiva, o estudo apresenta algumas proposições visando a melhoria do processo de contratação dos espaços, a otimização dos recursos aplicados nas realização dos eventos e a possibilidade de regulamentação da logística das seleções públicas. Assim, observado no estudo que o CESPE/CEBRASPE não realiza licitações para contratação de espaço, executando toda essa despesa por meio de contratações diretas, por meio de dispensa de licitação, fundamentada em 03 (três) incisos do art. 24, da Lei n. 8.666/1993, sendo eles o I, II e X. Isto posto, há a necessidade de algumas ações por parte do CESPE/CEBRASPE, nas quais destacamos o seguinte: [1] Descrever o modelo de espaço físico para realização dos eventos, haja vista que para qualquer modalidade de licitação, seja para aquisição de bens ou prestação de serviços, é imprescindível que haja a especificação do objeto a ser licitado, conforme já destacado na Súmula n. 177 do Tribunal de Contas da União (TCU). [2] Evitar a freqüente contratação direta, por meio de dispensa de licitação com base no art. 24, II, da Lei n 8.666/93, 
haja vista a utilização de forma inadequada desse inciso acarreta em fracionamento de despesa. [3] Evitar a contratação direta, por meio de dispensa de licitação com base no art. $24, \mathrm{X}$, da Lei $\mathrm{n}^{\circ} 8.666 / 93$, pois, conforme a doutrina, o referido inciso, deve ser utilizado apenas quando comprovada que a compra ou locação do imóvel atende as finalidades precípuas da administração e, ainda sim, com avaliação prévia da compatibilidade do preço de mercado. [4] Analisar a viabilidade de abertura de processo licitatório para obter proposta mais vantajosa para administração e otimizar os custos dos contratos celebrados. [5] Estudar a melhor forma de contratação dos espaços para realização de eventos públicos, buscando analisar as formas de contratações de outras bancas examinadoras públicas e privadas, para que se possa fazer um levantamento dos custos das contratações.

Por fim o estudo ainda apresenta situações que carecem de um aprofundamento, como: [a] Estudo aprofundado sobre locação de espaço público, no sentido de identificar o porque da instituição pública quando locada o recurso é repassado diretamente às secretarias de educação dos Estados e Municípios, e como essas secretarias estão tratando esses recursos. Pois esse estudo pode contribuir tanto para outros estudos que buscam identificar novas fontes de recursos para a educação como para vinculação desses recursos em determinantes da qualidade do ensino. [b] Sugere-se ainda um estudo mais aprofundado sobre a forma como as instituições públicas que receberam recursos com a locação dos espaços estão gastando os valores, haja vista que a presente pesquisa ratifica a infraestrutura como uma determinante na qualidade do ensino. [c] Pesquisa sobre as possibilidade de captação de recursos pelas instituições públicas, seja por meio de prestação de serviços ou de locação de espaço físico pois observou-se que há poucos estudos sobre o tema. 


\section{ANEXO "G" - PLANO DE AÇÃO}

\begin{tabular}{|l|l|}
\hline \multicolumn{2}{|c|}{ PLANO DE AÇÃo } \\
\hline Situação Geradora: & $\begin{array}{l}\text { Pesquisa exploratória realizada junto ao CESPE/CEBRASPE } \\
\text { demonstrou a disponibilidade de espaço público, com as } \\
\text { características mínimas exigidas pelo Centro, no Distrito Federal, para } \\
\text { realização de concurso público. } \\
\text { Falta de um modelo padrão de espaço a ser locado. } \\
\text { Alto volume de contratações diretas por meio de dispensa de licitação, } \\
\text { nos termos do art. 24, I, Il e X, da Lei no 8.666/93. }\end{array}$ \\
\hline Justificativa: & $\begin{array}{l}\text { Identificar se os espaços públicos podem substituir os espaços } \\
\text { privados contratados pelo CESPE/CEBRASPE no Distrito Federal }\end{array}$ \\
\hline Objetivo: & $\begin{array}{l}\text { Apresentar ações que possam otimizar os espaços públicos em } \\
\text { períodos ociosos, redução dos custos para realização de concurso } \\
\text { público executados pelo CESPE/CEBRASPE e apresentar forma } \\
\text { adequada de locação do espaço para realização dos eventos. }\end{array}$ \\
\hline Resultados Esperados: & $\begin{array}{l}\text { Melhorar a gestão das ações do CESPE/CEBRASPE quanto à } \\
\text { logística dos eventos, favorecendo o alcance dos objetivos } \\
\text { estabelecidos pelo CESPE/CEBRASPE }\end{array}$ \\
\hline Atuação do CESPE/CEBRASPE no Distrito Federal \\
\hline
\end{tabular}

\section{DESENVOLVIMENTO DAS AÇÕES}

\begin{tabular}{|c|c|c|c|c|}
\hline AÇÃO 1 & \multicolumn{4}{|c|}{$\begin{array}{l}\text { Descrever o modelo de espaço físico para realização dos eventos, haja vista } \\
\text { que para qualquer modalidade de licitação, seja para aquisição de bens ou } \\
\text { prestação de serviços, é imprescindível que haja a especificação do objeto a } \\
\text { ser licitado, conforme já destacado na Súmula n. } 177 \text { do Tribunal de Contas } \\
\text { da União (TCU). }\end{array}$} \\
\hline OBJETIVOS & \multicolumn{4}{|c|}{ Definir objeto a ser contratado } \\
\hline RECUROS & $\begin{array}{c}\text { PRAZO } \\
\text { EXECUÇÃO }\end{array}$ & RESPONSÁVEL & $\begin{array}{c}\text { PRINCIPAIS } \\
\text { STAKEHOLDERS }\end{array}$ & RELEVÂNCIA \\
\hline Não definido & 2 meses & $\begin{array}{l}\text { Diretoria de } \\
\text { Planejamento e } \\
\text { Controle } \\
\text { Operacional }\end{array}$ & $\begin{array}{l}\text { Diretoria de } \\
\text { Logística e } \\
\text { Diretoria de } \\
\text { Planejamento } \\
\text { Estratégico }\end{array}$ & Alta \\
\hline
\end{tabular}

\footnotetext{
${ }^{2}$ Adaptado de Antunes (2011).
} 


\begin{tabular}{|c|c|c|c|c|}
\hline AÇÃo 2 & \multicolumn{4}{|c|}{$\begin{array}{l}\text { Evitar a frequente contratação direta, por meio de dispensa de licitação com } \\
\text { base no art. } 24, \text { II, da Lei n } 8.666 / 93 \text {, haja vista a utilização de forma } \\
\text { inadequada desse inciso acarreta em fracionamento de despesa. }\end{array}$} \\
\hline OBJETIVOS & \multicolumn{4}{|c|}{ Controle preventivo para evitar fracionamento de despesa } \\
\hline RECUROS & $\begin{array}{l}\text { PRAZO } \\
\text { EXECUÇÃO }\end{array}$ & RESPONSÁVEL & $\begin{array}{l}\text { PRINCIPAIS } \\
\text { STAKEHOLDERS }\end{array}$ & RELEVÂNCIA \\
\hline Não definido & 2 meses & $\begin{array}{l}\text { Diretoria de } \\
\text { Licitações }\end{array}$ & $\begin{array}{l}\text { Direção Geral, } \\
\text { Auditoria Interna e } \\
\text { Assessoria } \\
\text { Jurídica }\end{array}$ & Alta \\
\hline AÇÃO 3 & \multicolumn{4}{|c|}{$\begin{array}{l}\text { Evitar a contratação direta, por meio de dispensa de licitação com base no } \\
\text { art. } 24, X \text {, da Lei } n^{\circ} 8.666 / 93 \text {, pois, conforme a doutrina, o referido inciso, } \\
\text { deve ser utilizado apenas quando comprovada que a compra ou locação do } \\
\text { imóvel atende as finalidades precípuas da administração e, ainda sim, com } \\
\text { avaliação prévia da compatibilidade do preço de mercado. }\end{array}$} \\
\hline OBJETIVOS & \multicolumn{4}{|c|}{$\begin{array}{l}\text { Avaliar se o imóvel de seja realmente indispensável para Administração } \\
\text { Pública, em razão das necessidades de instalação e localização }\end{array}$} \\
\hline RECUROS & $\begin{array}{l}\text { PRAZO } \\
\text { EXECUÇÃO }\end{array}$ & RESPONSÁVEL & $\begin{array}{l}\text { PRINCIPAIS } \\
\text { STAKEHOLDERS }\end{array}$ & RELEVÂNCIA \\
\hline Não definido & 2 meses & $\begin{array}{l}\text { Diretoria de } \\
\text { Licitações }\end{array}$ & $\begin{array}{l}\text { Direção Geral, } \\
\text { Auditoria Interna e } \\
\text { Assessoria } \\
\text { Jurídica }\end{array}$ & Média \\
\hline \multicolumn{5}{|l|}{ AÇÃO 4} \\
\hline OBJETIVOS & \multicolumn{4}{|c|}{$\begin{array}{l}\text { Analisar a viabilidade de abertura de processo licitatório para obter proposta } \\
\text { mais vantajosa para administração e otimizar os custos dos contratos } \\
\text { celebrados. }\end{array}$} \\
\hline RECUROS & $\begin{array}{l}\text { PRAZO } \\
\text { EXECUÇÃo }\end{array}$ & RESPONSÁVEL & $\begin{array}{l}\text { PRINCIPAIS } \\
\text { STAKEHOLDERS }\end{array}$ & RELEVÂNCIA \\
\hline Não definido & 6 meses & $\begin{array}{l}\text { Diretoria de } \\
\text { Licitações }\end{array}$ & $\begin{array}{l}\text { Direção Geral, } \\
\text { Auditoria Interna e } \\
\text { Assessoria } \\
\text { Jurídica }\end{array}$ & Média \\
\hline
\end{tabular}




\begin{tabular}{|c|c|c|c|c|}
\hline \multicolumn{5}{|l|}{ AÇÃO 5} \\
\hline OBJETIVOS & \multicolumn{4}{|c|}{$\begin{array}{l}\text { Estudar a melhor forma de contratação dos espaços para realização de } \\
\text { eventos públicos, buscando analisar as formas de contratações de outras } \\
\text { bancas examinadoras públicas e privadas, para que se possa fazer um } \\
\text { levantamento dos custos das contratações. }\end{array}$} \\
\hline RECUROS & $\begin{array}{c}\text { PRAZO } \\
\text { EXECUÇÃO }\end{array}$ & RESPONSÁVEL & $\begin{array}{c}\text { PRINCIPAIS } \\
\text { STAKEHOLDERS }\end{array}$ & RELEVÂNCIA \\
\hline Não definido & 6 meses & $\begin{array}{l}\text { Diretoria de } \\
\text { Planejamento e } \\
\text { Controle } \\
\text { Operacional }\end{array}$ & $\begin{array}{l}\text { Diretoria de } \\
\text { Logística e } \\
\text { Diretoria de } \\
\text { Planejamento } \\
\text { Estratégico }\end{array}$ & Média \\
\hline
\end{tabular}




\section{APÊNDICES}




\section{APÊNDICE "A" - EXTRATO DE ENTREVISTADOS}

\begin{tabular}{|l|c|}
\hline \multicolumn{1}{|c|}{ 1) Nome: } & Lucimar Oliveira do Nascimento \\
\hline Idade: & 41 anos \\
\hline Cargo: & Diretor de Logística \\
\hline Tempo de Serviço no Cargo Atual: & 2,5 anos. \\
\hline Tempo de Serviço na Instituição: & 22 anos \\
\hline Formação: & $\begin{array}{c}\text { Especialização em Governança em Tecnologia da } \\
\text { Informação }\end{array}$ \\
\hline
\end{tabular}

\begin{tabular}{|l|c|}
\hline \multicolumn{1}{|c|}{ 2) Nome: } & Francisco Clébio Dias de Oliveira \\
\hline Idade: & 37 anos \\
\hline Cargo: & Gerente de Logística \\
\hline Tempo de Serviço no Cargo Atual: & 4 anos \\
\hline Tempo de Serviço na Instituição: & 7 anos \\
\hline Formação: & Gestor em Logística \\
\hline
\end{tabular}

\begin{tabular}{|l|c|}
\hline \multicolumn{1}{|c|}{ 3) Nome: } & Sérgio Antônio Andrade de Freitas \\
\hline Idade: & 49 \\
\hline Cargo: & Diretor Executivo do CESPE/UnB \\
\hline Tempo de Serviço no Cargo Atual: & 1 ano e 2 meses \\
\hline Tempo de Serviço na Instituição: & 6 anos e 8 meses \\
\hline Formação: & $\begin{array}{c}\text { Graduação em Engenharia de Computação (UFU), } \\
\text { Mestre em Informática (UFRGS) e Doutor em } \\
\text { Engenharia Elétrica (UFES) }\end{array}$ \\
\hline
\end{tabular}

\begin{tabular}{|l|c|}
\hline \multicolumn{1}{|c|}{ 4) Nome: } & Eudes de Queiroz e Silva \\
\hline Idade: & 53 \\
\hline Cargo: & Gestor Financeiro \\
\hline Tempo de Serviço no Cargo Atual: & 3 anos \\
\hline Tempo de Serviço na Instituição: & 4 anos \\
\hline Formação: & Administrador \\
\hline
\end{tabular}




\section{APÊNDICE "B" - IMAGENS DAS ESCOLAS}

1) Imagens de uma escola privada:
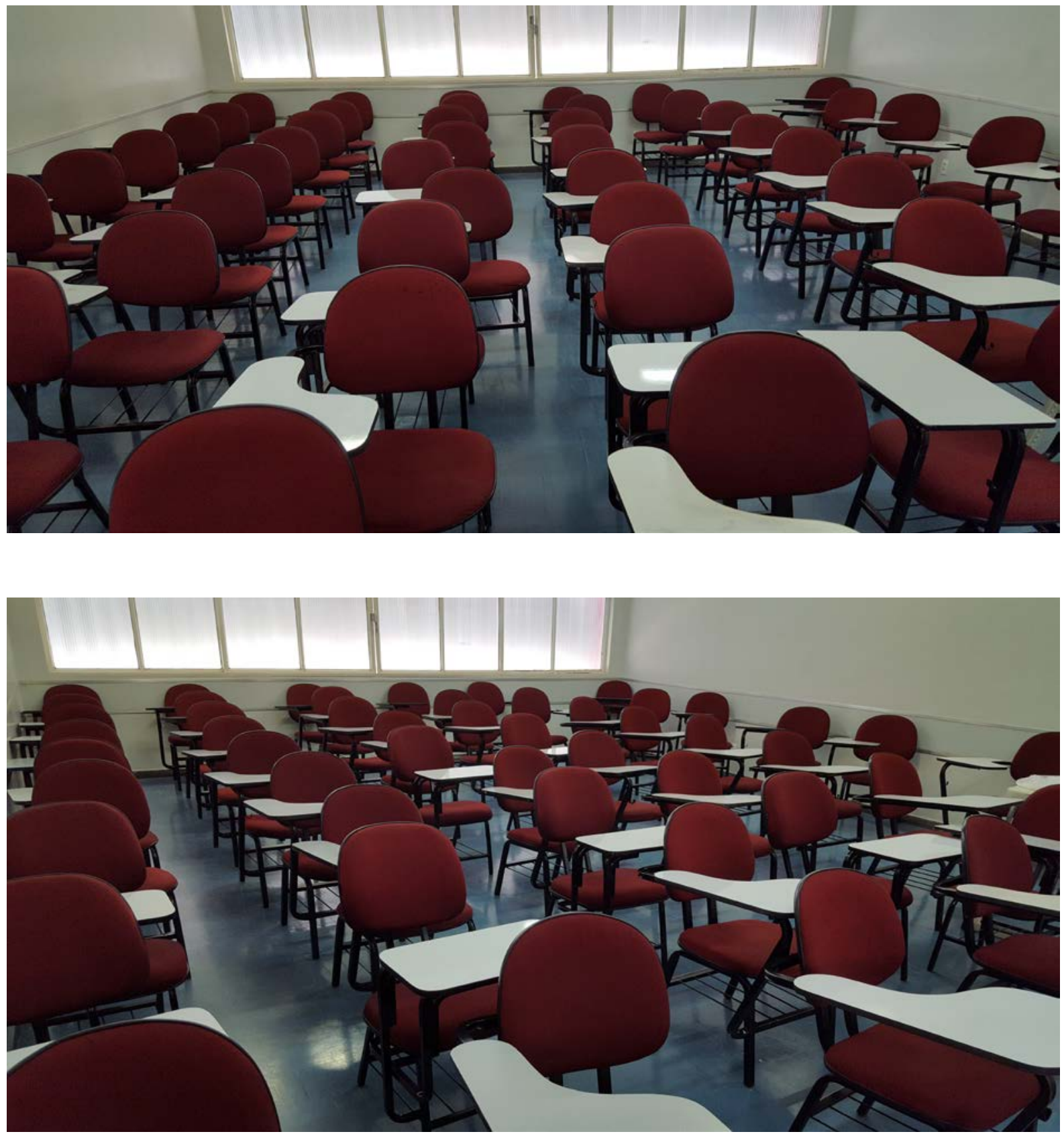


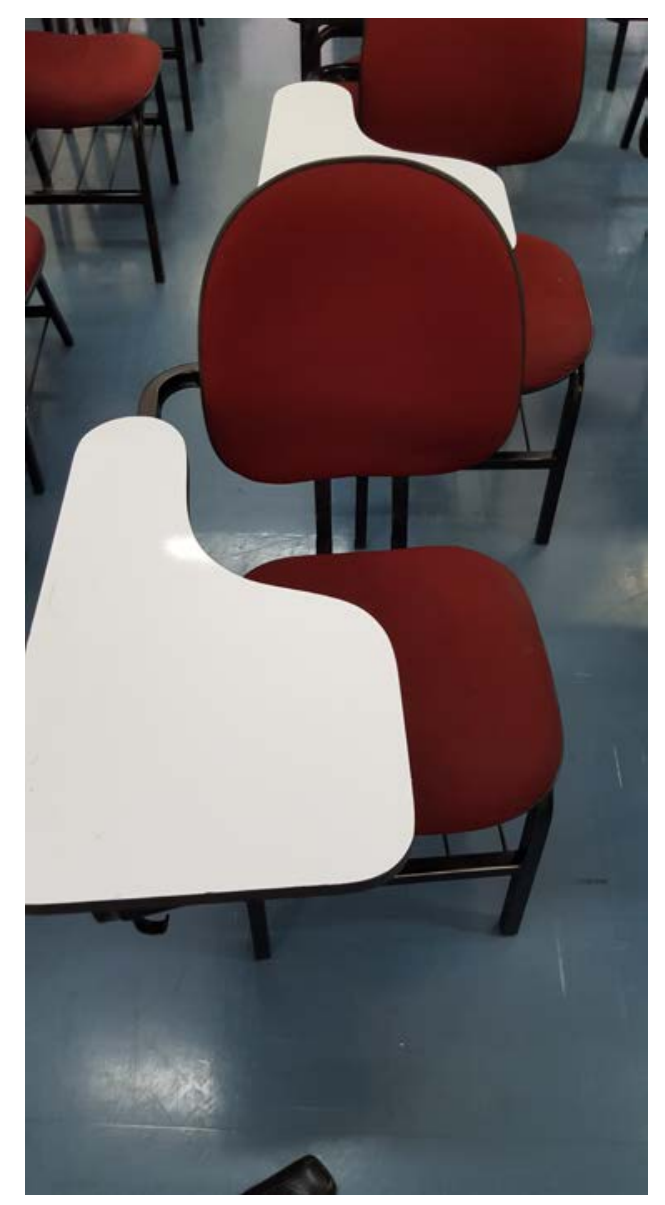

2) Imagens de uma escola pública:

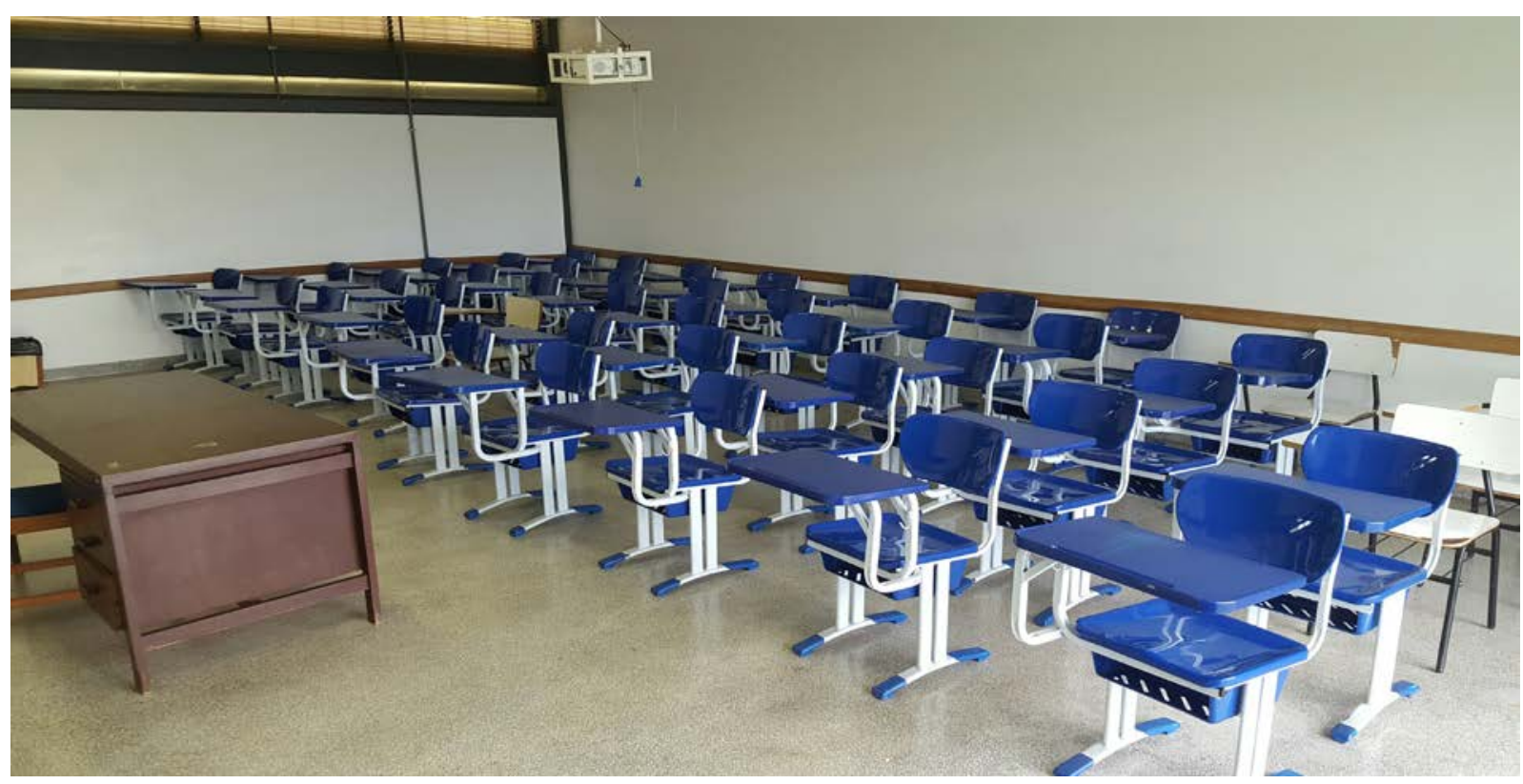




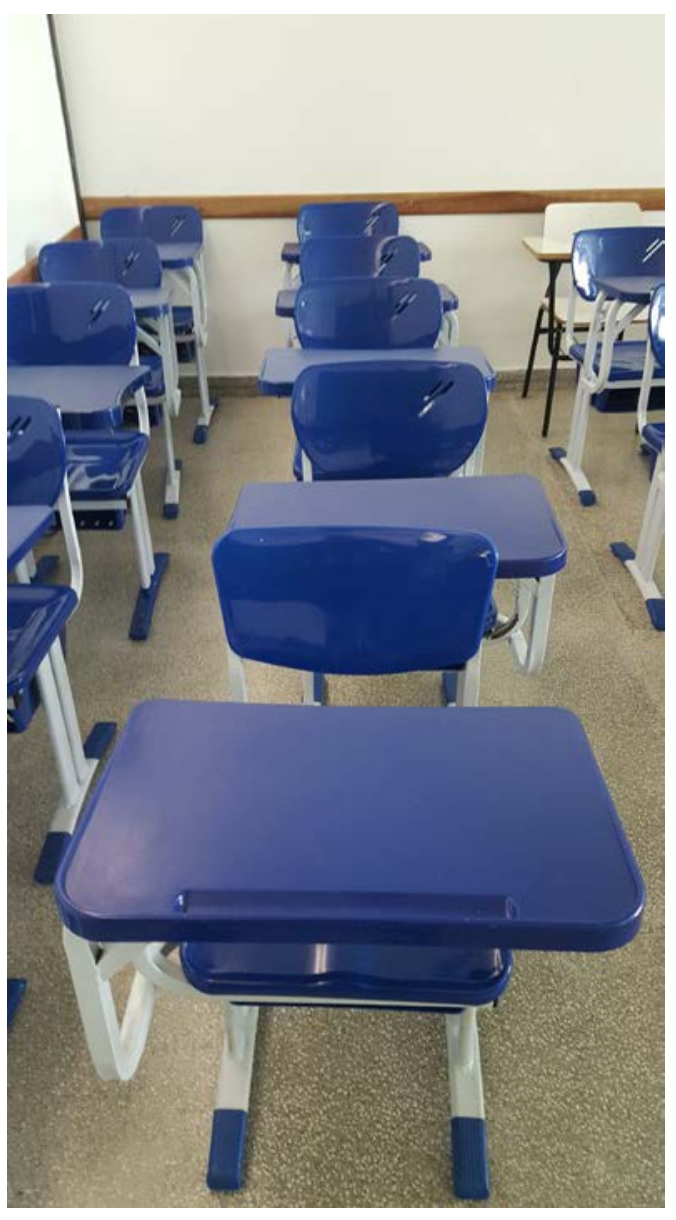

